\title{
The Rational Apocalypse of the Latitudinarians in Restoration England
}

Park, Jeongkyu

How to cite:

Park, Jeongkyu (2018) The Rational Apocalypse of the Latitudinarians in Restoration England. Doctoral thesis, Swansea University.

http://cronfa.swan.ac.uk/Record/cronfa44763

Use policy:

This item is brought to you by Swansea University. Any person downloading material is agreeing to abide by the terms of the repository licence: copies of full text items may be used or reproduced in any format or medium, without prior permission for personal research or study, educational or non-commercial purposes only. The copyright for any work remains with the original author unless otherwise specified. The full-text must not be sold in any format or medium without the formal permission of the copyright holder. Permission for multiple reproductions should be obtained from the original author.

Authors are personally responsible for adhering to copyright and publisher restrictions when uploading content to the repository.

Please link to the metadata record in the Swansea University repository, Cronfa (link given in the citation reference above.)

http://www.swansea.ac.uk/library/researchsupport/ris-support/ 


\title{
The Rational Apocalypse of the Latitudinarians in Restoration England
}

\author{
Jeongkyu Park
}

Submitted to Swansea University in fulfilment of the requirements for the Degree of Doctor of Philosophy

Swansea University

2018 


\begin{abstract}
This thesis examines latitudinarians' apocalyptic ideas during the Restoration period. These Anglicans have been considered by historians in terms of their role in promoting rational theology. However, there has been little analysis of the whole aspects of latitudinarian apocalyptic belief. This thesis surveys a variety of works to demonstrate a continuing tradition of apocalyptic worldview in their political and religious from the Restoration to the Revolution of 1688-1689. Chapter one summarises the English apocalyptic tradition that spanned the sixteenth century to early seventeenth century. English Protestants formed the key patterns of apocalyptic thought, and this apocalyptic tradition continuously influenced the Cambridge Platonists and many latitudinarian divines in the seventeenth century. Chapter two demonstrates that apocalyptic notions played an important part in latitudinarians' anti-Catholic sentiment. Chapter three explains how these moderate Anglicans utilized apocalyptic ideas to justify the English Reformation and the Church of England. Chapter four explores the way in which the latitudinarians placed the debate of the royal supremacy within the apocalyptic context of the godly ruler. Lastly, chapter five focuses on how their expectations of the future fulfilment of divine apocalyptic promises led to the emphasis of moral reform. The fear of divine judgment and the hope of complete salvation motivated the latitudinarian clergy to promote the moral reformation. It also demonstrates that the latitudinarians' proposal of moral reform implied their optimistic view of human nature, perfectibility of men, achieved through religious edification. In a broad sense, the examination of various aspects of latitudinarians' religious thought shows the existence of the traditional apocalyptic framework in late seventeenth-century England.
\end{abstract}




\section{DECLARATION}

This work has not previously been accepted in substance for any degree and is not being concurrently submitted in candidature for any degree.

Signed (candidate)

Date

\section{STATEMENT 1}

This thesis is the result of my own investigations, except where otherwise stated.

Other sources are acknowledged by footnotes giving explicit references. A bibliography is appended.

Signed (candidate)

Date

\section{STATEMENT 2}

I hereby give consent for my thesis, if accepted, to be available for photocopying and for inter-library loan, and for the title and summary to be made available to outside organisations.

Signed (candidate)

Date 


\section{Contents}

Introduction

Chapter 1

The English Apocalyptic Tradition and the Cambridge Platonists

1.1. Apocalyptic Pattern: The Historical Interpretation of the Prophecies 21

1.2. Apocalyptic Pattern: England the Godly Nation.

1.3. The Cambridge Platonists' Apocalypticism

Chapter 2

The Anti-Popery of the Latitudinarians and the Debate over Antichrist

2.1. Antichrist, Idolatry and Tyranny: The Characteristics of Antichrist 57

2.2. The Political Context of Anti-Catholicism .68

2.3. The Debate over the Identity of Antichrist in the Restoration .73

2.4. The History of the Church's Degeneration .................................................... 79

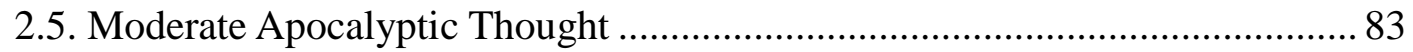

2.6. The Possibility of the Salvation of Roman Catholics 88

Chapter 3

The Apocalyptic Vision of the True Church and the Church of England

3.1. The Providential Historiography of the Reformation 94

3.2. Anglican Primitivism against Roman Gentilism 107

3.3. Primitive Virtues and Rationality 116

3.4. The Continuity between the Church of England and the Primitive Church .. 122

3.5. Motives for Further Reformation 125

Chapter 4

The Latitudinarian Ideal of the Godly Ruler

4.1. The Anglican Commemorations of the Restoration Monarch

4.2. The Glorious Revolution and the Apocalyptic Justification of the Monarch 142

4.3. The Royal Supremacy Debate 146

4.4. The Latitudinarians' Account of Royal Supremacy 
4.5. The Charge of Erastianism against the Latitudinarians ............................... 157

4.6. The Godly Ruler's Primary Duty: Religious Unity ................................... 165

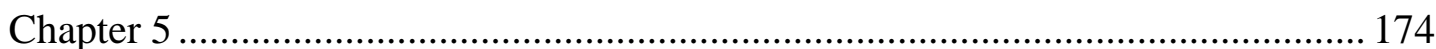

Providence, Progress, and Moral Reform

5.1. The Fear of Divine Judgement.................................................................. 179

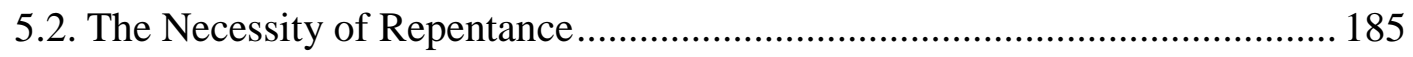

5.3. Human Capacity for Moral Reform: Latitudinarian Soteriology ................. 191

5.4. The Hope for the 'Perfection' of Human Nature ........................................... 201

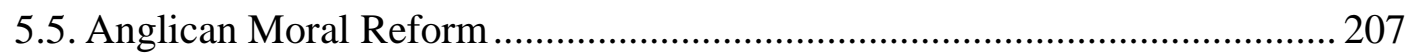

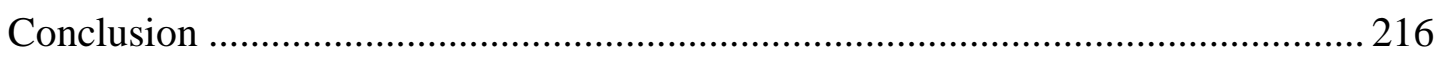

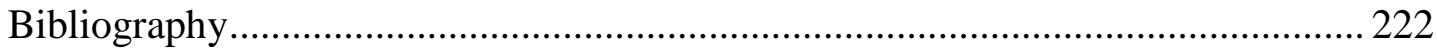




\section{Acknowledgements}

The research and writing of this thesis would have been impossible without the encouragement and support of the following people. First of all, I would like to give sincere thanks to Professor John Spurr for providing academic advice and helpful guidance. He gave me a great opportunity to conduct doctoral research under his supervision and helped me refine my ideas throughout my doctorate research candidature. He inspired me with his deep knowledge of seventeenth-century England. I am also thankful to Dr. Regina Poertner, my second supervisor, for her helpful suggestions about the anti-popery discourse and Catholicism in seventeenthcentury Europe.

I am grateful to the Kim Hee-Kyung Scholarship Foundation for European Humanities of South Korea for their funding and support of this research, which enabled me to complete this research. I am especially grateful to John Aaron. He read the final draft of the thesis and provided comments and suggestions which have been invaluable in helping me correct many errors weaknesses in this thesis. Dr. Soohyeong Kim's comments on the introduction were also very helpful.

All the staff and colleagues in the Arts and Humanities community at Swansea University were kind and supportive. Particularly Liz Whitwell, Postgraduate Research Support Administrator, was always happy to assist me in many ways. I am thankful for the friendship and support I was given while I lived in the wonderful city, Swansea, Wales. I am indebted to Rio Althagafy, Brandi Hill, Sadiq Altamimi, Ulas Inci, Shareena H. Osbourne, Ben Jones, Meilyr Powel, Francesca Lavery-Firth, Catherine Yakun Yu, Wu Arianna, Bibo Akraka Aganaba, Christopher Goffin and Junghwan Choi (now at Exeter University) for their friendship and encouragement. I am also grateful to the church family at Ebenezer Baptist Church and Waterfront Korean Church who were all good and faithful friends.

Finally, I owe a significant debt to my family, especially my wife, Chunwoo Lee, for all her assistance and support in the last few years. Without her encouragement, I might have never finished writing this thesis. My parents, parentsin-law and my two sisters, Seungeun and Jeongwon, also provided unconditional care over many years. 


\section{Introduction}

Seventeenth-century England experienced, simultaneously, persecution and tolerance, divine right kingship and resistance theory, revealed religion and natural science. When we think of seventeenth-century religious history, it is difficult to interpret and explain this period in a simple way. Recent historians have shown that a confrontation between competing streams of religious thought marked this as a transitional period between tradition and modernity. Basil Willey is a representative scholar who titles the second chapter of his book 'Twofold Truth' to describe different responses to religious problems. ${ }^{1}$ Early modern thinkers struggled to demonstrate religious truth not only within a traditional framework inherited from the middle ages but also by means of a rational and scientific approach. It is widely acknowledged that a series of religious works by seventeenth-century authors pose an exciting challenge to historians who have paid particular attention to the dimensions of religious culture. Political and religious upheavals in the later Stuart period challenged the status quo and encouraged gradual changes in the way early modern English people thought of religion. Yet traditional religious beliefs and practices persisted, or even remained unshaken.

My thesis is an attempt to understand this ambiguity. The thesis focuses specifically on the use of apocalyptic ideas by a small group within the restored Church of England, called the 'latitudinarians'. Their theology has often been considered as relying particularly upon the principles of rationality and moderation. Many conclude that their rational approach in searching for religious truth came from their break with the old intellectual tradition and was the main theme of their works. At the same time, apocalyptic ideas in religion and associated notions - Eschatology, Millenarianism, Messianism and so on - have been recognised as part of a conventional theological approach based upon the exegesis of the prophetical books of the Old Testament and the Book of Revelation. Latitudinarians' apocalyptic thought was presented within a conventional theological framework. More interestingly, however, their use of apocalyptic language was not a mere repetition of

\footnotetext{
${ }^{1}$ Basil Willey, The Seventeenth Century Background: Studies in the Thought of the Age in Relation to Poetry and Religion (London: Chatto and Windus, 1934), chap. 2.
} 
the traditional way of understanding the Scriptures. It also reveals that they were preoccupied with finding an appropriate way of applying apocalyptic language to contemporary events. The latitudinarians' apocalyptic mode of thought highlights the blurred lines that existed between the traditional and rational world-views at a time when religion and politics were not yet separated. Why should these Anglicans' interest in apocalyptic belief deserve our attention? It is because their apocalyptic ideas seem to represent a transitional phase in religious culture. This double-edged aspect of seventeenth-century religion, as John Pocock mentions in The Machiavellian Moment, played an important role in the development of modern political thought. ${ }^{2}$ This study of their mode of interpreting the apocalypse will reveal religious transitions and transformations as it examines how the latitudinarian divines not only inherited traditional concepts but also adjusted the apocalyptic imagination in the Restoration context. Therefore, by considering the latitudinarians in their religious context of seventeenth-century England it is possible to explain the gap between the modern perception of them as rational theologians and their own worldview based on apocalyptic beliefs. In short, this study is an examination of the significance of the relationship between two differing concepts - Apocalypticism and rationality - by the consideration of key notions in their apocalyptic interpretations.

Modern scholarship in relation to the Anglican latitudinarians has paid relatively little attention to their apocalyptic belief. The term 'latitudinarian' has been contentious since it was used to describe them in a disparaging way. For many centuries the latitudinarians have been regarded as Whigs in politics and Deists in religion. From the early eighteenth-century many writers evaluated these Anglican divines on the basis of their alleged avowal of Socinian doctrines. The English Jesuit John Constable (d. 1743) published under anonymous cover Deism and Christianity Fairly Consider'd in Four Dialogues (1739) to compare latitudinarian theology with deist doctrines. Constable concluded that there was little difference between the latitudinarians and deists because Anglican latitudinarians pretended to 'hold a God, and yet deny his Providence' as deists did likewise. ${ }^{3}$ The Catholic bishop Richard Challoner (1691-1781) also identified the latitudinarians as a radical group who had 'almost banished religion from this kingdom; and laughed out of doors both the

\footnotetext{
2 J. G. A. Pocock, The Machiavellian Moment: Florentine Political Thought and the Atlantic Republican Tradition (Princeton: Princeton University Press, 1975), chap. 12.

3 John Constable, Deism and Christianity Fairly Consider'd, in Four Dialogues (London1739), 212-13.
} 
belief and practice of Christianity', linking them with atheists, deists, and freethinkers. ${ }^{4}$ When a Scottish philosopher and historian David Hume (1711-1776) explained the characteristics of Whigs in Essays and Treatises on Several Subjects (1753), he wrote that 'since the origin of whig and tory, the leaders of the whigs have either been deists or profest latitudinarians in their principles; that is, friends to toleration, and indifferent to any particular sect of Christians' 5 From this perspective, it has been widely contended that the latitudinarians diminished reverence for revealed religion by grounding the concept of religion on the notions of natural religion and minimal dogma.

At the beginning of the twentieth century, Edward Augustus George claimed that the latitudinarians emphasised individual reason against traditional religious customs and dogmas. George argued that in this group 'there was a revival of the original Protestant emphasis upon freedom of personal inquiry, which unfortunately had been stifled as the Reformation advanced by a period of dogmatic uniformity'. ${ }^{6}$ During the last several decades many studies on the latitudinarians have concentrated on rational and modern tenets of latitudinarian theology. This trend has contributed to the classification of the latitudinarians as a specific group of rational and modern theologians who formed a movement for reason, toleration, and natural religion. The assumption that the seventeenth century was a progressive period in terms of secularisation and rationalisation has supported the perception of many historians of the latitudinarians. G. R. Cragg's conviction that 'the Restoration succeeded an age in which religion had been discussed with an unparalleled intensity and the new era bore all the marks of a period of reaction' marks his understanding of the latitudinarians. Cragg claims that 'in the reaction against enthusiasm they linked religion with the rising authority of reason; in the impatience with restraints they insisted on the obligations of a sober morality'. ${ }^{7}$ Jackson I. Cope argues that 'latitudinarianism has come to be synonymous with Anglican tolerationism in the best sense'. ${ }^{8}$ Henry G. van Leeuwen explores the contributions the latitudinarians

\footnotetext{
${ }^{4}$ Richard Challoner, A Short History of the First Beginning and Progress of the Protestant Religion, Gathered out of the Best Protestant Writers, 12th ed. (London, 1795), 59.

${ }_{5}$ David Hume, Essays and Treatises on Several Subjects, vol. 1 (London, 1753), 112.

${ }^{6}$ Edward Augustus George, The Seventeenth Century Men of Latitude: Forerunners of the New Theology (New York: C. Scribners' sons, 1908), 195-96.

${ }^{7}$ Gerald R. Cragg, From Puritanism to the Age of Reason: A Study of Changes in Religious Thought within the Church of England, 1660 to 1700 (Cambridge: Cambridge University Press, 1950), 10, 86.

8 Jackson I. Cope, "“The Cupri-Cosmits": Glanvill on Latitudinarian Anti-Enthusiasm', Huntington Library
} 
made to the development of modern English Protestant thought. He acknowledges that scientific theory in relation to the problem of the certainty of human knowledge was 'initially formulated' by Chillingworth and Tillotson and 'developed and used in the context of science by John Wilkins and Joseph Glanvill, and then by Robert Boyle, Isaac Newton, and John Locke'. ${ }^{9}$ B. J. Shapiro traces the connection between the latitudinarian group and scientific activities. She notes that the latitudinarians as a whole were 'enthusiastic about the new philosophy', and some of them especially were 'propagandists for both science and latitudinarianism'. ${ }^{10}$ John Coffey claims that the latitudinarians, including the Cambridge Platonists, 'became advocates of toleration', and they 'undermined the foundations of intolerance by popularising a new religious style, one characterised by openness, ecumenism and "reasonableness". 11 This interpretation of the seventeenth century posits that from the Restoration there was a direct connection between these moderate Anglican divines and intellectual innovations which has been recognised as being key tenets of the early Enlightenment movement.

Against such a scholarly trend, revisionist historians have recently focused their attention on intellectual continuity by re-examining the religious thought of the latitudinarians. It is remarkable that for the past decades many historians have tried to show the continuity of traditional ideas in the seventeenth century. There has been an increasing emphasis on the continuing and transitional dimensions of the seventeenth-century intellectual conflicts with which the latitudinarians engaged. While many have understood the seventeenth century in the context of the sharp contradiction between competing concepts, reason and religion, some, over the past two decades, have attempted to rethink them in a new way, and encouraged academic debate over their identity. It has been widely acknowledged that the latitudinarians had only limited ideas of reason and moderation. It is in this sense that John Spurr questions the previous assumptions concerning latitudinarianism. Spurr's research demonstrates that the latitudinarians' religious thought was not far different from the majority of the Church of England and that they played a significant part in

\footnotetext{
Quarterly 17, no. 3 (1954): 271.

${ }^{9}$ Henry G. Van Leeuwen, The Problem of Certainty in English Thought, 1630-1690 (The Hague: Martinus Nijhoff, 1963), 14.

10 B. J. Shapiro, 'Latitudinarianism and Science in Seventeenth-Century England', Past and Present 40, no. 1 (1968): 31.

${ }^{11}$ John Coffey, ed., Persecution and Toleration in Protestant England, 1558-1689 (Harlow: Longman, 2000), 50.
} 
preaching up Christian moral duties. Spurr suggests that a call for rational religion was not the preserve of the latitudinarians alone. He argues that both the Church of England and Nonconformists were convinced that they maintained a rational religion, and the latitudinarians were just one party amongst others who tried to establish Christianity on rational grounds. ${ }^{12}$ As William Bulman points out, Spurr's scrutiny of latitudinarianism represents that all the characteristics of this Anglican group 'have no basis in the historical evidence, or apply to nearly all leading Restoration clergy. ${ }^{13}$

After Spurr, many attempts to place the latitudinarians within the context of a religious and intellectual continuity have been made. For example, W. M. Spellman emphasises that 'the Latitudinarian call to reason and the emphasis on behavior in this life in no sense obscured their understanding of the function of evil, nor did this position diminish the gravity of their commitment to a Christian humanism' while they were interested in the new system of theology in response to a challenge to enthusiasm and atheism in the later seventeenth century. ${ }^{14}$ Justin Champion argues that the latitudinarians' application of rationality to the study of the Scriptures and ecclesiastical history aimed at establishing 'a true and identifiable Christian religion that excluded other religions as heresy or heathenism'. ${ }^{15}$ Isabel Rivers also stresses that the latitudinarians emphasised human reason and a new style of preaching in order to define the relationship between faith and works. Rivers concludes that traditional Anglican soteriology was never far from the latitudinarians' mind. ${ }^{16}$ Jeffrey S. Chamberlain claims that for all latitudinarians' admitted natural religion, they also 'had no doubts that revealed religion was absolutely necessary'. Chamberlain's research suggests that to some extent these rational theologians accepted both rational accounts of religion and the traditional concepts of revealed religion. ${ }^{17}$ Jonathan I. Israel argues that the leading latitudinarians like Stillingfleet

12 John. Spurr, The Restoration Church of England, 1646-1689 (New Haven: Yale University Press, 1991), chap. 4; “"Latitudinarianism” and the Restoration Church', The Historical Journal 31, no. 1 (1988): 78-9; “"Rational Religion" in Restoration England', Journal of the History of Ideas 49, no. 4 (1988): 568-69.

${ }^{13}$ William J. Bulman, 'Enlightenment and Religious Politics in Restoration England', History Compass 10, no. 10 (2012): 758.

${ }^{14}$ W. M. Spellman, The Latitudinarians and the Church of England, 1660-1700 (Athens, Georgia: University of Georgia Press, 1993), 6.

15 J. A. I. Champion, The Pillars of Priestcraft Shaken: The Church of England and Its Enemies, 1660-1730 (Cambridge: Cambridge University Press, 1992), 25-6, 99.

${ }^{16}$ Isabel Rivers, Reason, Grace, and Sentiment: A Study of the Language of Religion and Ethics in England, 1660-1780, Vol. 1, Whichcote to Wesley (Cambridge: Cambridge University Press, 1991), 73-7.

17 Jeffrey S. Chamberlain, 'The Limits of Moderation in a Latitudinarian Parson: Or, High-Church Zeal in a Low 
clearly denied new ways of thinking such as Socinian tenets and radical principles of atheism, deism, and pantheism, and maintained traditional Christian doctrines, although they 'occupied a central position in the Early Enlightenment, emerging as leading representatives ... of a powerfully modernizing, rational theology'. ${ }^{18}$ These studies pay particular attention to the relationship between the latitudinarians' emphasis on traditional religious principles and their appeal to the rational way of dealing with religious conflicts.

Although significant contributions to an historiographical re-evaluation of the nature of the latitudinarians have been made, it has often been assumed that the latitudinarians were preoccupied with promoting the new style of ideas and rhetoric. In fact, John Pocock remarkably mentions a close connection between apocalyptic thought and latitudinarians' religious thinking. Pocock writes that 'it was one thing for millennial expectation to serve as a framework in which to present schemes of rational optimism and rational explanation'. He continues to claim that 'there are signs of a paradox in the English intellectual scene: republicans like Toland, in so many ways the heirs of the Puritans, emerge as Deists and foes of the prophetic tradition, while the apocalyptic mode of thought is carried on by latitudinarians who are professed enemies of "enthusiasm." 19 Pocock finds it intriguing that the latitudinarians' concerns with God's providential scheme made up the theological framework of these proponents of rationality. But he does not go on to explore in detail how their use of apocalyptic language reflected their endeavour to understand contemporary political and religious matters and to incorporate new ideas in the development of their own thought. However, he cannot help but view seventeenth century England as a paradoxical society where conventional speculations on religion coexisted with new approaches to deal with political and religious changes. Pocock's statement of the latitudinarians' concern with the apocalypse implies that religious discourses went into eclipse and that secular ideas replaced the old Protestant culture in public life. He implies that traditional concepts, such as apocalyptic ideas, had little impact on contemporary intellectual life in seventeenthcentury England.

Churchmen Discover'd', in The Margins of Orthodoxy: Heterodox Writing and Cultural Response, 1660-1750, ed., Roger D. Lund (Cambridge: Cambridge University Press, 1995), 204-8.

18 Jonathan I. Israel, Radical Enlightenment: Philosophy and the Making of Modernity, 1650-1750 (Oxford: Oxford University Press, 2001), 470, 524.

${ }^{19}$ Pocock, The Machiavellian Moment: Florentine Political Thought and the Atlantic Republican Tradition, 403. 
Yet the apocalyptic mode of thought had long been sustained and had wielded substantial influence on the English people at least up to the late seventeenth century. There had been many advocates for an apocalyptic framework within which all past events in the world could be explained and all future events could be broadly predicted. A number of historians have focused upon the importance of apocalyptic eschatology as set forth from the Restoration period onwards. One of the most remarkable studies of apocalyptic belief in the early modern period is by Ernest Lee Tuveson. Tuveson's research is typical of the current orthodoxy in that he attempts to trace how old ideas transmuted into a modern worldview. He demonstrates that the interpretation of the apocalypse and the belief in providential history provided 'the germ of a new attitude' towards human history. In this study, Tuveson explores a particular theologian who has been broadly identified as a predecessor of the latitudinarians, Henry More. He considers More's apocalyptic interpretation of the Scriptures, and asserts that More 'carried progressivism into the heart of his millennial doctrine' and believed that 'a course of perfectibility is the true plot of history'. ${ }^{20}$ More recent scholarship has continued to explore the continuity of certain aspects of apocalyptic thought. Paul J. Korshin's study outlines apocalyptic interpretations in the later seventeenth century. In this study Korshin insists that apocalyptic thought 'did not die out during the English Enlightenment but rather, abetted by a steady stream of fundamentalist Christian, Jewish, and - in Britain's new empire - Islamic visionaries, flourished throughout the eighteenth and early nineteenth centuries'. ${ }^{21}$ Avihu Zakai argues that Protestant historiography 'based itself upon a historical interpretation of prophecies and stressed the apocalyptic scheme of events, that is, the Apocalypse is to be regarded as the guide to history' from the reign of Queen Elizabeth to the mid seventeenth century. ${ }^{22}$ These efforts have contributed to demonstrating the continued influence of various apocalyptic interpretations on political and religious discourse during the sixteenth and seventeenth centuries. $^{23}$

\footnotetext{
${ }^{20}$ Ernest Lee Tuveson, Millennium and Utopia: A Study in the Background of the Idea of Progress (New York: Harper \& Row, 1964), 45-6, 93-9.

${ }_{21}$ Paul J. Korshin, 'Queuing and Waiting: The Apocalypse in England, 1660-1715', in The Apocalypse in English Renaissance Thought and Literature: Patterns, Antecedents, and Repercussions, eds., Constantinos Apostolos Patrides and Joseph Anthony Wittreich (Ithaca, N.Y: Cornell University Press, 1984), 240-41.

${ }_{22}$ Avihu Zakai, Exile and Kingdom: History and Apocalypse in the Puritan Migration to America (Cambridge: Cambridge University Press, 1992), 14-5.

${ }^{23}$ See, for example, Paul Christianson, Reformers and Babylon: English Apocalyptic Visions from the
} 
The emphasis on apocalyptic beliefs was not limited to puritan radicals. Some historians have helped us to recognise that the study of apocalyptic prophecies remained vital to Anglican clergy and lay people. Tony Claydon's examination of the apocalypticism of some latitudinarians suggests that the moderate version of apocalyptic ideas remained potent among the latitudinarians after the Restoration. Claydon articulates the use of apocalyptic terms by the latitudinarians, in particular, Gilbert Burnet, to elaborate their religious discourse. Claydon demonstrates that Burnet's apocalyptic interpretation of history played a key role in promoting the Williamite reformation after the Revolution of 1688-89 and his ideas 'constituted a powerful statement of Orange legitimacy'. ${ }^{24}$ In his broad examination of Anglican Apocalypticism, Warren Johnston notes that 'the efforts by royalists and Anglicans to defend their beliefs in the established political and religious institutions rebutted nonconformist criticisms applying the same prophetic terms, and this formed another facet of Apocalypticism in the years from 1660 to $1700{ }^{25}$

However, while the importance of apocalyptic ideas in seventeenth-century England has been well acknowledged, the fact that the apocalyptic speculation set forth by Anglicans or, more specifically, latitudinarians, played an important role in their theological system in the second half of seventeenth century, has still been overlooked. Given that there has been growing interest in Anglican apocalyptic discourse in the seventeenth century, it is noticeable that the study of the interpretation of the apocalypse from the latitudinarian perspective has been relatively marginalised. Despite some prominent studies on these Anglicans' theology, the conventional premise that a new philosophy was manifest in their discussions of religion has had a constant impact on the historiography of the latitudinarians, because of their alleged eagerness in promulgating rational theology. Claydon's analysis is mainly confined to Gilbert Burnet's apocalyptic thinking.

Reformation to the Eve of the Civil War (Toronto: University of Toronto Press, 1978); Katharine R. Firth, The Apocalyptic Tradition in Reformation Britain, 1530-1645 (Oxford: Oxford University Press, 1979); James E. Force and Richard H. Popkin, eds., Millenarianism and Messianism in Early Modern European Culture, Vol. 3, the Millenarian Turn: Science, Politics, and Everyday Anglo-American Life in the Seventeenth and Eighteenth Centuries (Dordrecht Kluwer Academic, 2001); Jeffrey K. Jue, Heaven Upon Earth: Joseph Mede (1586-1638) and the Legacy of Millenarianism (Dordrecht: Springer, 2006); David Andrew Drinnon, 'The Apocalyptic Tradition in Scotland, 1588-1688' (Ph.D. dissertation, University of St Andrews, 2013).

${ }^{24}$ Tony Claydon, William III and the Godly Revolution (Cambridge: Cambridge University Press, 1996), 24-63; 'Latitudinarianism and Apocalyptic History in the Worldview of Gilbert Burnet, 1643-1715', The Historical Journal 51, no. 3 (2008): 577-97.

${ }^{25}$ Warren Johnston, Revelation Restored: The Apocalypse in Later Seventeenth-Century England (Woodbridge: Boydell Press, 2011), 19-20; 'The Anglican Apocalypse in Restoration England', The Journal of Ecclesiastical History 55, no. 3 (2004): 467-501. 
Claydon acknowledges that apocalyptic belief was a feature of latitudinarian thinking but he does not provide a broad outline of the latitudinarian use of apocalyptic language. Johnston also explains the apocalyptic ideas set forth by some of these Anglicans. Yet, his statement of their apocalyptic interpretation is limited to a few comments on their apocalyptic literature. Both historians fail to account for ways in which traditional apocalyptic ideas were applied by the latitudinarians to their particular circumstances.

It is important to stress, therefore, that latitudinarian responses to political and religious changes during the Restoration owed much to their apocalyptic and providential convictions. The latitudinarians were concerned with the apocalyptic narrative of the Scriptures, and this established their own attitudes towards the apocalyptic interpretation of contemporary events, albeit not in the same way in every case. This thesis is designed to explore their apocalyptic mode of thought and its correlations with other aspects of their whole body of thought during the Restoration period in England.

The main approach to this study is to describe the apocalyptic patterns of latitudinarians' thought and to contextualise these within the political and religious debates with which they were involved. The thesis surveys the multiple genres of literature - essays, tracts, pamphlets, and sermons - written from the Restoration and the late seventeenth century by Anglican clergy who have been classified as the latitudinarians by many historians. As the latitudinarians are a loosely defined Anglican group, it is still controversial as to who are to be identified as the latitudinarians by definition, and what is difference between the latitudinarians and other Anglican divines. Although there is disagreement about its number, this thesis follows the general consensus with respect to the key Anglican latitudinarians - John Tillotson (1630-1694), Edward Stillingfleet (1635-1699), Joseph Glanvill (16361680), Simon Patrick (1626-1707), Edward Fowler (1632-1714), Jeremy Taylor (1613-1667), Gilbert Burnet (1643-1715), and others. Some of the Cambridge Platonists like Henry More (1614-1687), who are regarded as being closely connected with the latitudinarians, are also included in this study. The latitudinarians kept on good terms with each other and their doctrines were strongly influenced by the Cambridge Platonists, especially More and William Chillingworth.

When it comes to identifying the latitudinarians, the number and membership 
of the group has often been controversial. However, it is clear that, from the Restoration onwards, an identifiable network of divines had emerged who wished to share their concern about the contemporary situation through their preaching, writing and public influence. At an earlier stage of their careers, with exceptions of Burnet and Glanvill, who matriculated at Marischal College, Aberdeen, and at Oxford respectively, most of these divines were educated in Cambridge where their theological convictions were nurtured by the Cambridge Platonists. A few of them started ministerial career from the 1650s and had therefore compromised with the requirements of the puritan regime. After 1660, a latitudinarian circle formed in London where these young divines moved to begin their ministerial practice. Patrick took up his position at St. Paul's, Covent Garden, from 1662, while Tillotson was invited to preach at Lincoln's Inn in 1663; Stillingfleet was appointed rector at St Andrews, Holborn in 1665; Burnet was made a royal chaplain in 1674; Sharp became rector at St Giles-in-the-Fields; in 1680 Tenison succeeded William Lloyd at St Martin-in-the-Fields. Their location in the capital city was a crucial to their ability to maintain close intellectual connection throughout the Restoration period. Although their influence remained marginal in the Restoration Church of England during the reign of Charles II and James II, they became dominant from the 1690s when, with the new Williamite regime established, the new monarch used them to fill episcopal vacancies. Many of them including Burnet, Patrick, Tillotson, Fowler, Stillingfleet and others were appointed new bishops during 1689 and 1692.

In respect of theology, these divines did not distinguish themselves from the majority of Anglican churchmen. However, it is misleading to say that their religious and political views were parallel with other conformist colleagues on all matters. One of the most noticeable aspects of their outlook was a conciliatory attitude towards dissenters. Their irenic stance towards dissenting Protestants could have partly stemmed from the fact that these clergymen had started ministerial practice in ecclesiastical circumstances which were very different from those of post-1660 England. In the 1650s, they had conformed to the loose ecclesiastical settlement under the Cromwellian government, and then rapidly adapted to the Restoration establishment of 1662. Most were educated during the 1650s and the early 1660s, and were acquainted with and respected many of the sober Nonconformist laymen or clergy. Throughout the Restoration period, they continued to keep a relatively good 
relationship with members of dissenting groups and their sympathisers. This affected their approach to ecclesiastical and political issues. As I shall show soon, they retained their hopes of religious unity under the Church of England, and they did so by arguing for the necessary of 'comprehension'.

My thesis has two main aspirations. First, this thesis will examine how the latitudinarians interpreted apocalyptic texts and images in the Scriptures. Many works dealt with biblical texts such as prophetic passages in the Old Testament and the Book of Revelation of the New Testament. Their understandings of these apocalyptic texts were different from those advanced in other denominations. An analysis of their religious language will sketch the broad outline of the apocalyptic terms and rhetoric that they commonly used. Secondly, this study will reveal the ways in which the apocalyptic interpretation of the Scriptures was employed to support the hegemony of the Church of England and the monarchy. Although textual analysis in this study is useful in demonstrating the extent to which the latitudinarians expressed religious thought in conventional language, it is difficult to understand the relationship between the words and their meanings without a knowledge of the historical context. ${ }^{26}$ A certain word had different meanings at the same time in different circumstances. A number of their printed works were made up of terms within the religious domain, and the motivation for their publications was, directly or indirectly, related to specific religious and political circumstances. It is important to note that the latitudinarians' use of apocalyptic terms reflected on their religious position within the Church of England and their political attitude towards Restoration politics. Moreover, the extent to which apocalyptic belief was expressed varied because of other different religious and political issues. Therefore, this thesis attempts to show the interaction between their apocalyptic terms and the religious and political discourses in which the latitudinarians were involved. This approach will help to place the latitudinarians' religious thought in the context of the English Restoration.

The title of this thesis may be confusing to some readers in terms of the meaning of the 'rational' because many are inclined to conceive the 'rational' as opposed to the 'apocalyptic'. Although scrutiny of the linguistic implications of

\footnotetext{
26 This method has been employed, for example, by Quentin Skinner. See Quentin Skinner, The Foundations of Modern Political Thought, Vol. 1, the Renaissance (Cambridge: Cambridge University Press, 1978), x-xii.
} 
'rational' as a word is beyond the scope of my thesis, I hope to show how the latitudinarian's advocacy of 'rational religion' is to be properly understood within seventeenth-century religious culture. While the rationality of human reason attracted Englishmen of every religious persuasion, the reason which latitudinarian clergymen proclaimed arose in large part as a hostile reaction against puritan 'enthusiasm', or even atheism. ${ }^{27}$ When latitudinarian Anglicans applied rational reasoning to their apocalyptic analysis, they expected that their exposition of biblical mysteries could protect the veracity of the Scriptures from religious enthusiasm and atheistic disregard of the revelation. They were sceptical of the way in which their religious opponents understood prophetical messages. In dealing with prophecy, these Anglicans stressed that it was important to take a cautious approach to apocalyptic interpretation of the Scriptures, and that it was necessary to base prophetic interpretation upon the common sense. They wanted to show that rational reasoning could help hidden knowledge of the apocalypse to be revealed. As I shall show in following chapters, latitudinarians' emphasis on human reason did not undervalue apocalyptic discourse. The basic assumption underlying their idea of the relationship between reason and divine providence was that reason was not contrary to divine revelation. They thought that rational reason could support divine revelation by providing sufficient evidence to prove God's revealed and mysterious words to be true.

My thesis comprises of five chapters. While the first chapter attempts to provide a brief outline of the tradition of English apocalyptic belief from the sixteenth-century to the early seventeenth century, the main four chapters offer detailed examinations of apocalyptic language in close connection with the main controversial issues raised during later seventeenth-century England. Chapter 1 begins with an introductory note about the terminology of apocalyptic ideas and clarifies the basic characteristics of various forms of the Christian apocalyptic tradition: Apocalypticism, Providentialism and Millenarianism, which had developed in different ways amongst different groups across Europe.

The main body of this chapter traces the English Protestant apocalyptic

\footnotetext{
27 The term 'reason' was much discussed by a large number of different religious denominations and traditions in Restoration England. See John Spurr, "Rational Religion” in Restoration England'; Christopher Haigh, 'The Church of England, the Nonconformists and Reason: Another Restoration Controversy', The Journal of Ecclesiastical History 69, no. 3 (2018): 531-56.
} 
tradition from the English Reformation in the sixteenth century. This chapter is divided into three parts; the first two will provide a background explanation of the development of key notions of Protestant apocalyptic understanding before the Restoration in terms of time and place - one discusses the historicist understanding of the apocalypse and the other considers the apocalyptic understanding of England as an elect nation; the third part will provide a general account of the Cambridge Platonists' apocalyptic views.

The first part of chapter 1 demonstrates that English Protestants who were preoccupied with the fulfilment of apocalyptic prophecies attempted to place the images in the biblical prophecies within the history of the Protestant Church, and this inspired the sixteenth-century Reformers to employ the various types of apocalyptic ideas as rhetorical device in their support for the Protestant Reformation. It is widely acknowledged that from the mid sixteenth century to the early seventeenth century many remarkable efforts to promote Protestant apocalyptic and providential historiography had been made by prominent Protestant writers. As I will show, in Protestant apocalyptic historiography the Henrician Reformation was accepted as one of those moments when divine providence intervened in human history in order to fulfil God's prophetic plan.

The second part continues to outline the historical process of the imminent fulfilment of the apocalypse by which the role of England as an elect nation emerged. In this part, therefore, it is worth noting, in particular, that a rising trend of an apocalyptic approach to the study of English history from the Henrician Reformation inspired the Protestant authors to be interested in the revelation of God's plan throughout English history. Once the Protestants accepted the new idea of historiography that God's providential scheme could be evidently seen in history, they came to believe that the apocalypse would be firmly placed within the boundaries of time and space.

The last part of chapter 1 discusses the Cambridge Platonists' apocalyptic interpretation of prophecies - particularly those of Henry More. Given that efforts to seek the intellectual similarities between the Protestant apocalyptic apologetics and these rational theologians have been made by historians, I agree that the latitudinarians drew upon the sixteenth-century apocalyptic writers and the Cambridge Platonists for their apocalyptic concepts. By analysing Henry More's 
influence on an apocalyptic model set forth by the latitudinarians, this section of the chapter suggests that the key patterns of apocalyptic belief which were developed from the English Reformation were embedded in the Cambridge Platonists and the younger generation of the latitudinarians.

Chapter 2 focuses on the religious context of the anti-Catholic polemic of the latitudinarians during the Restoration. Whilst the approach of identifying Catholicism with antichrist in latitudinarian apocalyptic understanding has been analysed in modern historiography, there is more to say about historical implication of the use of anti-popish semantics in the seventeenth-century intellectual background. In this chapter, therefore, further consideration is given to the significant connection between the latitudinarian understanding of Antichrist? Their anti-popery distinguished them from other religious groups because they combined the apocalyptic tradition and 'rational theology', a key value for the theology of latitudinarian divines. The first part of the chapter explains how the latitudinarians understood the apocalyptic term, Antichrist, in their apocalyptic interpretation of the prophecies. The second part examines the religious context in which the latitudinarians shaped their own concepts of anti-popery through their linguistic controversy with other denominational polemicists over the nature of the Antichrist. The last part focuses on their application of anti-popery language to pastoral practices. As a whole, the chapter is an attempt to argue that the latitudinarians' interpretations of Antichrist reflected the way in which they adjusted the implication of the apocalyptic term to the religious circumstances they faced.

Chapter 3 aims to examine the way in which apocalyptic language used by the latitudinarians was employed to support the Church of England. Their use of providential rhetoric was manifest in the controversy over the nature of 'true religion'. The justification of the Church of England as a 'true church' was an important theme in the historical investigation of the nature of the establishment of the English Church. The chapter, therefore, begins with some of the major latitudinarian historical and apocalyptic narratives of the primitive church and of the English Reformation in the sixteenth century. The first half of the chapter deals with the latitudinarians' concern with the historical vindication of the Church of England. It analyses the apocalyptic interpretation of history shown in their various works. The last section of this chapter is devoted to an explanation of how the latitudinarians 
synthesised apocalyptic narratives and the discourse of the primitive church into their justification of the Church of England as a true establishment in a providential sense.

Chapter 4 describes latitudinarian attitudes towards one of the main elements of English politics, the monarchy. It is well known that the latitudinarians were not far from the mainstream of Anglicans in claiming the legitimate authority of the prince. In doing so, the chapter also rethinks the Erastian tenet of the latitudinarians' vindication of the authority of the civil magistrate over religious matters by examining how they combined the apocalyptic justification of the civil ruler with competing political discourses. The chapter needs to draw peculiar elements of the latitudinarian defence of kingship into a broad picture of intellectual discourses concerning the role of the civil magistrate. Thus the chapter will first of all examine the use of the apocalyptic language of Anglican clergy to sanctify the authority of the king in the context of religious and political debates. The first part of this chapter gives a detailed explanation of the latitudinarian emphasis on the apocalyptic significance of the victory of the Protestant monarchs. In the second part, it continues by demonstrating the characteristics of the role of the monarch in their understanding of divine kingship. Lastly, in sum, the Erastian aspects of their political thought is reassessed in the context of religious circumstances during the Restoration.

Chapter 5 shows the relationship between latitudinarian apocalyptic belief in English history and their view of moral reform. While many have shown the latitudinarians' efforts to promote the religious campaigns for moral reform during the Revolution of 1688-89, this chapter focuses on their constant emphasis on moral reform throughout the period from the Restoration to the Glorious Revolution, both at an individual and a national level. The first part of this chapter demonstrates how the latitudinarians made use of apocalyptic language to urge moral revival. In the last part, I attempt to pay attention to their soteriology in which they refute Calvinist and Catholic doctrines of salvation. This leads to the suggestion that the latitudinarians' theological claim of salvation by human works and of the possibility of human perfectibility cannot be understood without their apocalyptic belief in God's punishment and reward for human beings. 


\section{Terminology}

Before discussing the apocalyptic tradition, the definition of various terms explaining apocalyptic belief is needed. In the Christian world, apocalyptic ideas which explored the relationship between the existence of God and the reason for the creation of all things in this world were explained at various levels. Over many centuries the text of Scripture provided a strong basis for these ideas. Historians have categorised apocalyptic thought under several terms: 'providence', 'apocalypse', and 'millennium'. These terms were used in the formation of intellectual terminology: 'providentialism', 'apocalypticism', and 'millenarianism'. Generally, providence was the term ascribed conventionally to the ordering of world by divine omnipotence and omniscience. ${ }^{28}$ In the sixteenth and seventeenth centuries, the Reformation theologians were convinced that nothing could happen without God's permission. The possibility of chance or accident in world events was underestimated, while a sense that the world was absolutely under the control of divine providence underlay the providential worldview. ${ }^{29}$ Although rational attempts to argue that God's providence did not influence every single act but was merely the original cause of creation (as illustrated by the image of the universe as a well-made clock which worked mechanically as God had exquisitely designed) gained ground in the eighteenth century, yet a sense of divine providence remained strong in the minds of early modern Englishmen at least until the late seventeenth century. In this way this providential viewpoint encouraged people to believe that human society and individual activity were related to natural phenomena. The reality of providence was manifest in a widespread reaction against natural disasters or unusual changes in the human environment. Just as with biblical messages, so natural prodigies and supernatural wonders were interpreted as divine signs to men. Therefore, prodigies, William Burns reveals, were directly connected with 'divine providential punishments of individual sinners or groups of sinners' or rewards for religious virtues. ${ }^{30}$ This belief in divine providence has been linked by many historians to be Puritans or sectarians. Indeed, early modern historians have focused upon Puritan

\footnotetext{
${ }^{28}$ Peter Geach, Providence and Evil: The Stanton Lectures, 1971-2 (Cambridge: Cambridge University Press, 1977), 1.

${ }^{29}$ Keith Thomas, Religion and the Decline of Magic: Studies in Popular Beliefs in Sixteenth and Seventeenth Century England (London: Weidenfeld and Nicolson, 1971), 90-2.

${ }^{30}$ William Burns, An Age of Wonders (Manchester: Manchester University Press, 2002), 2-3.
} 
providentialism or the providential convictions of various religious minorities. ${ }^{31}$ Meanwhile Alexandra Walsham suggests that providentialism is not 'a marginal feature of the religious culture of early modern England, but part of the mainstream, a cluster of presuppositions which enjoyed near universal acceptance' ${ }^{32}$ In short, there was a strong sense of providentialism among the laity in early modern England. The lay people were likely to derive certain lessons, either for individuals or societies, from catastrophic events. Many jumped to the conclusion that the end of the world was imminent. Alexandra Walsham offers a history of the English laity's understanding of the relationship between providence and natural events from the sixteenth century. For example, a merchant-tailor Henry Machyn understood a gale in July 1561 as a sign that dooms-day was coming soon. ${ }^{33}$ This notion of providential thought provided the framework of the Christian worldview which enabled people to view each event in relation to the belief that God is in direct control of His creation and the universe.

Apocalyptic ideas, or apocalypticism, are closely related to providentialism. English Protestants in the early modern period believed that an apocalyptic scheme was being carried out in accordance with divine providence. Apocalypticism focused upon the exposition of biblical prophecies such as the Book of Daniel and the Book of Revelation, and sought the religious implications that God intended to be understood in these prophetic texts. This apocalyptic thought, as Paul Christianson argues, contains three characteristics: 'a polarized view of the universe', that the conflict between two pillars of good and evil underlies the world; 'a catastrophic explanation of events'; 'a firm concern with prophecy and its fulfilment'. 34 Apocalypticism presupposed that the destiny of the world hinged upon the struggle between good and evil. It is natural, therefore, to claim that the cosmic battle between two forces of good and evil seeking to take control of the universe manifested itself in the individual events of each phase of history. There was no doubt that the power of good on God's side would eventually defeat evil forces, and that the result would be the triumph of good and the eternal destruction of evil. The

\footnotetext{
${ }^{31}$ For the providential thought of puritans or sectarians see Firth, The Apocalyptic Tradition in Reformation Britain, 1530-1645; Thomas, Religion and the Decline of Magic: Studies in Popular Beliefs in Sixteenth and Seventeenth Century England, chap. 4 on Providence.

32 Alexandra Walsham, Providence in Early Modern England (Oxford: Oxford University Press, 1999), 2-3.

${ }^{33}$ Ibid., 127.

${ }^{34}$ Christianson, Reformers and Babylon: English Apocalyptic Visions from the Reformation to the Eve of the Civil War, 5.
} 
Protestants thought that since this conflict between two rival forces revealed itself by a series of catastrophic events, then such events would be continued until the final victory against the enemy, according to divine plan.

From the early modern period, as the Reformation encouraged Christians to read and interpret the Scriptures for themselves, the exponents of apocalyptic ideas showed a growing interest in apocalyptic motifs. In their eyes, the Scriptures guaranteed the achievement of prophecy declared directly in God's words or by the medium of his disciples. The whole framework of the apocalypse was confirmed by its previous prophecies, and even though some predicted things did not take place, that did not gently undermine faith in the reality of prophecy until a new scientific worldview replaced the conventional Christian one. For English reformers, the most important function of the biblical prophecies was to denote what would happen to Christians in the future.

What mattered was to know how to interpret the images of the prophecies. The biblical images of prophecies were employed by many Protestants to provide an appropriate tool for their theology, but the use of images was made in varying degrees. In doing so, apocalyptic thinkers were inclined to match these biblical metaphors to historical events or to current situations. Natural catastrophes were identified with some significant moments of the apocalyptic historical narrative. Earthquakes, famines, plagues and conflagrations were thought to give symbolic accounts of major phases of apocalyptic history. In apocalyptic thought, these disastrous events, at last, would lead to the fulfilment of prophecies. All apocalyptic thinkers presented themselves as prophets who were able to foretell events and the result of the apocalypse by their interpretation of prophecies. Prediction of the future was built into the very nature of the apocalyptic mode of thought to a greater or lesser degree. ${ }^{35}$ The possibility of fulfilment of prophecy enabled the people to take part in describing what would come to pass in the long term. In so doing, apocalyptic thought played a key role in the incorporation of prophecies and their fulfilment in history.

Some Protestants went on to discuss the biblical prophecies of Christ's reign on earth and defeat of Antichrist in a more detailed way. Many historians demonstrate how this aspect of apocalyptic thought engendered the movement of the

\footnotetext{
35 Ibid., 6-7.
} 
millennium. With some variations of interpretation, such as 'pre-millenarianism', 'post-millenarianism' and 'amillenarianism', belief in the millennium contained some key apocalyptic elements like the binding of Satan for a thousand-year period and the reign of the triumphant Christ on earth. This type of thought was mainly presented by the radical Protestants rather than by Anglican conformists and moderate dissenters in early modern England. For various reasons, these puritans or other radical denominations who shared millenarianism expected the imminent transformation of life on earth through divine intervention, and consequently this hope for the future required them to take action by any means. ${ }^{36}$ Millenarians and their radical movements encountered hostility from the majority of Christians because mainstream Christians in England tended to deny a radical or even militant interpretation of the millennium, even if they generally shared a religious culture with their radical contemporaries. ${ }^{37}$ In short, millenarianism is a specific version of belief in a messianic reign, while apocalyptic thought is the generic term denoting the whole framework of biblical propheticism.

\footnotetext{
36 Ibid., 7.

${ }^{37}$ Michael Barkun, ed., Millennialism and Violence (London: Frank Cass, 1996), 52.
} 


\section{Chapter 1 \\ The English Apocalyptic Tradition and the Cambridge Platonists}

This chapter is an outline of English apocalyptic thought from the Reformation to the mid-seventeenth century. Modern scholarship has taken for granted the decline of apocalyptic ideas in the public arena, yet the English tradition of an apocalyptic way of thinking had long been sustained and had substantial influence on Englishmen at least up to the late seventeenth century. There were many advocates for the apocalyptic framework within which all past events in the world could be explained and all events to happen in the future could broadly be predicted.

The purpose of this chapter is to give a brief account of the apocalyptic tradition which passed down to the latitudinarians whose theology has been thought to incline towards a modern world view. For this purpose, the chapter has three tasks: the first two involve showing two key patterns - those of prophecy and national purpose - in apocalyptic ideas in the sixteenth and early seventeenth centuries. This is done by surveying English apocalyptic exegetes such as John Bale, John Foxe, Thomas Brightman, and Joseph Mede. The third is to illustrate the continuity of the apocalyptic tradition from these sixteenth-century predecessors through to the seventeenth-century Anglican divines, and to demonstrate that the Cambridge Platonists accepted and developed the apocalyptic tradition, and influenced their younger latitudinarian clergy. One of the prominent commentators among the Cambridge Platonists was Henry More. This chapter will, therefore, look at the way in which More adopted the interpretative tradition by which the latitudinarians understood the prophecies.

English apocalyptic theory rested upon the Protestant emphasis on the fulfilment of prophecy in human history and in the role of church and government. These two elements were central to the way Protestants understood the apocalypse. In sixteenth-century England an apocalyptic mode of thought consisting of apocalyptic images and terms was developed to meet the need for justifying the Reformation. Protestant writers saw the apocalypse in historical events. From the Reformation all variations of apocalyptic understanding required an historical study both of the past and of the attitudes towards present authorities, both of politics and 
of religion. Apocalyptic signs were synchronised with the dates of world history. In early modern thought, time was perceived as a linear process of change. In contrast to the medieval idea of a circular process of time, early modern minds gradually understood that the future was somewhat different from the present. Apocalyptic ideas encouraged the perception of history as progressing according to divine design. ${ }^{1}$ The idea of an eventual apocalypse inevitably led thinkers to consider the importance of change in human history. Hence the study of history accepted an apocalyptic view of time, and human history was understood to progress towards a designated future. On the other hand, apocalyptic thought could justify support for or resistance to the monarchy and the church. For Anglicans, especially, apocalyptic understanding of Christian history led to the justification of the monarchy and of the Church of England. The early seventeenth century saw apocalyptic belief still serving as a powerful political weapon against opponents. ${ }^{2}$

It is now widely acknowledged that apocalyptic convictions were not merely espoused by radical nonconformists but also by Anglicans. Adherents to the Established Church did not hesitate to employ apocalyptic ideas. Given that it has been admitted that the latitude-men were mainly affected by the moderate and rational theology of the Cambridge Platonists, it is natural to assume that latitudinarian providential convictions were partly influenced by the Cambridge Platonists like Henry More. The moderate Anglicans' apocalyptic views demonstrate the enduring impact of providentialism on the mainstream of English Protestantism.

\subsection{Apocalyptic Pattern: The Historical Interpretation of the Prophecies}

An apocalyptic mode of thought was an intellectual framework in which humans, societies, and the Christian church could be understood. Apocalyptic thought has had a long history in Europe since the emergence of Christianity. The early disciples who were scattered to spread their belief in Christ as the Son of God, shared the prophetic promise of Christ's return to fulfil God's purposes, as dramatically described by the images and visions in St. John's Book of Revelation. As the primitive church spread

\footnotetext{
${ }^{1}$ Bertrand Taithe and Tim Thornton, eds., Prophecy: The Power of Inspired Language in History 1300-2000 (Stroud: Sutton, 1997), 9.

${ }^{2}$ Warren Johnston, 'The Anglican Apocalypse in Restoration England', The Journal of Ecclesiastical History 55, no. 3 (2004): 469.
} 
out across Europe, the apocalyptic tone of biblical interpretation gained ground, and the images in the prophecies of Daniel and Revelation were used in the pulpit in many ways. Prior to the Reformation, St. Augustine of Hippo was the most notable interpreter of prophecies. He rejected the application of apocalyptic prophecies to human history but deciphered them in a spiritual way. For Augustine, the apocalyptic scheme was related to human salvation, not with history as such, and therefore the complete salvation of human soul was placed beyond the time of history. ${ }^{3}$

In fact, during the Middle Ages, papal supremacy had prevented apocalyptic thought from having much influence on the lay people. Only a few heretics employed it to undermine papal authority. The pope did not feel any need to promote millenarian visions for the future in that the Roman Church proclaimed itself as the true, holy, and universal church. The Church believed that the expectation of the writers of biblical prophecies was already achieved when Christianity was established as the state religion in the Roman Empire. By the early sixteenth century, however, a tradition of interpreting apocalyptic images historically and of identifying the papacy with Antichrist had been reinvigorated. Early Protestant reformers started to exploit an apocalyptic sense of times that the present world they were living in was coming to an end, and an identification of the reformed church as a precursor of the final glorious age of millennium in the world. They saw the spiritual split with Rome as a critical event in the fulfilment of apocalyptic prophecy. ${ }^{4}$

Not all ages of Christians had viewed the prophecies of Revelation and Daniel as history with some providential events. Until the Reformation there had been a long tradition of understanding the prophecies merely as an allegory of spiritual life. Two prominent writers, Otto of Freising and Joachim of Fiore represented this traditional interpretation of the prophecies. Otto of Freising, the pupil of Hugh of St. Victor, followed the pattern of two cities as set forth by St. Augustine. In contrast to Augustine, however, who thought that the city of God was spiritual, Otto identified this city with the Roman Church, writers of the Church and the Roman Empire as two cities of God and man. Within this framework Otto could construct a dual system of spiritual and temporal powers in Christendom. Otto

\footnotetext{
3 Avihu Zakai, 'Reformation, History, and Eschatology in English Protestantism', History and Theory 26, no. 3 (1987): 305.

${ }^{4}$ Warren Johnston, Revelation Restored: The Apocalypse in Later Seventeenth-Century England (Woodbridge: Boydell Press, 2011), 3-4.
} 
thought the Book of Revelation depicted a period of 'a thousand years' as an indefinite period so he argued that the Roman Church as the city of God would continue till the end of history. Thus the final stage of the world would be revealed in the collapse of the Holy Roman Empire or of the Roman Church. By doing so he suggested that the prophecies did not describe some future history of the world, but rather he warned Christians to prepare for the final stage of divine judgement. ${ }^{5}$

While Otto emphasised the spiritual nature of the prophecies, Joachim of Fiore, a twelfth-century abbot, argued for the fulfilment of prophecy throughout the world-history of the Church. For Joachim, the vision of seven seals in the Book of Revelation corresponded to the history of the Christian Church in the time of the apostles. The whole story of history then consisted of two parts: the present age of the Son and the future age of the Spirit. ${ }^{6}$ His assurance of a time of peace to come and spiritual perfection in Holy Spirit on earth before the final judgment influenced later generations by suggesting that the biblical prophecies represented a continuation of the history of the Church with the possibility of the improvement of the Church within history. ${ }^{7}$

These early attempts to place prophetical visions within the history of the Christian church inspired the sixteenth-century Reformers to employ the apocalyptic theme as a rhetorical device in their support for a new religious movement. They came to believe that salvation history occurred within secular history. The interpretation of the prophecies in the later middle ages, as Joachim argued, enabled the integration of sacred history within secular history. The sixteenth-century Protestants turned their eyes toward history in order to establish the significance of the Reformation in sacred, providential history. ${ }^{8}$ Instead of insisting on making a clear distinction between sacred history and secular history, Protestant historiography assumed that the course of salvation would be realised in history. From this historiographical perspective, the sixteenth-century reformers understood the Reformation as the great work of divine providence with respect to the fulfilment of the prophecies in human history. Apocalyptic theory was regarded as the guide to the

\footnotetext{
5 Katharine R. Firth, The Apocalyptic Tradition in Reformation Britain, 1530-1645 (Oxford: Oxford University Press, 1979), 2-4.

${ }^{6}$ Ibid., 4. For Joachim's influence on later generations until the Reformation see Marjorie E. Reeves, The Influence of Prophecy in the Later Middle Ages: A Study in Joachimism (Oxford: Clarendon Press, 1969), part 2, 3 and 4.

${ }^{7}$ Firth, The Apocalyptic Tradition in Reformation Britain, 1530-1645, 5.

${ }^{8}$ Zakai, 'Reformation, History, and Eschatology in English Protestantism', 300.
} 
history of the Church.

It is important to note that the apocalyptic understanding of human history employed humanistic techniques in interpreting biblical texts. In theological controversies between the Reformation and the Counter-Reformation, the Humanist intellectual movement of the sixteenth century had a synergistic effect on the study of the history of the Church. Adopting aspects of Renaissance thought, Christian Humanists turned to the historical literature of the Church, including the Scriptures, and developed apocalyptic expectations. Philological research of the Biblical texts helped some Humanists - even radical exponents for apocalyptic mysticism like the Italian Dominican friar Girolamo Savonarola - to improve their ability in analysing mystical prophecies and thus reinforce various types of apocalyptic hopes. ${ }^{9}$

Equally relevant to the thought of the Reformers and their sympathisers were the theological and financial corruptions of the Roman Church. Criticism of Rome, and of the whole structure of the Catholic Church in general, ran high in the late Middle Ages. ${ }^{10}$ As the universal authority of the papacy with its temporal and spiritual powers was rejected, it was necessary to build up an equivalent authority. To the Protestants, the Roman Church was no longer the true church. The Reformed church was now the true church. The prophetic interpretation of Church history met the needs of Protestants for justifying the Reformation as a manifestation of divine providence. Martin Luther, for example, was initially sceptical about the validity of the Book of Revelation in the Bible. He dismissed its prophecy, fearing radical aspects of apocalyptic belief which seemed to instigate the rebellions of radical sectarians such as the Anabaptists. ${ }^{11}$ However, his attitude changed. In his revised version of the German Bible in 1530, Luther admitted the necessity of the prophecies for the reformed Church. He discovered the attack on papal authority from a study of biblical history. He realised that history and prophecy could be used together on behalf of the Protestant cause. ${ }^{12}$ Calvin was also reluctant to make use of the book of Revelation. Moreover, in his discussion of the relationship between human history

\footnotetext{
${ }^{9}$ Reeves, The Influence of Prophecy in the Later Middle Ages: A Study in Joachimism, part 4, chap 4.

${ }^{10}$ Bernard McGinn, Visions of the End: Apocalyptic Traditions in the Middle Ages (New York: Columbia University Press, 1998), 270.

${ }^{11}$ Luther's scepticism with respect to the book of Revelation is seen clearly in his 'Preface to the Revelation of St. John' in 1522. He said, 'I miss more than one thing in this book, and it makes me consider it to be neither apostolic nor prophetic'. Martin Luther, Luther's Works, Vol. 35, Word and Sacrament I, ed., E. Theodore Bachmann (Philadelphia: Fortress Press, 1960), 398.

${ }^{12}$ Firth, The Apocalyptic Tradition in Reformation Britain, 1530-1645, 12-3.
} 
and God's providence, he did not consider that it was possible to understand God's providential plan in the light of secular history. Due to the limited capacity of human knowledge, he thought that any efforts to understand the apocalypse within human history would not guarantee any more accurate knowledge of divine providence. ${ }^{13}$ However, it was clear to him that he could identify the Antichrist. Calvin thought that the historical revelation of Antichrist was a reference to the pope. In Daniel's prophecy, Calvin thought, Antichrist's monarchy was the papacy arising in history after the four kingdoms. ${ }^{14}$ By identifying the Antichrist with the Catholic Church based upon his theological rejection of Catholicism, Calvin would pass the tradition of apocalyptic historiography down to later generations. As Protestants strove to undermine the very foundation of the supreme authority that the Catholic Church had enjoyed for centuries, Protestant historiography became a strong weapon that could be used to attack the very claim of Catholicism that its authority relied upon tradition transmitted from the primitive Fathers over the centuries.

More importantly, the Protestant emphasis on the study of history in terms of the apocalyptic achievement of divine revelation gave rise to a public interest in national history along with a justification of the secular authority in each country and of the Protestant Church against the Catholic Church. It is worth noting, in particular, that the movement of religious renewal had ramifications for national historiography. As the movement spread across Europe, it 'stimulated a strong interest in national history in countries such as England, Poland, Bohemia, Hungary, France, Denmark, and Sweden'. ${ }^{15}$ In Protestant countries, national history played a significant role in demolishing the historical significance of papal authority and in associating the Protestant Church and the civil magistrates with rhetorical devices that derived from historical studies. The realisation of a grand providential scheme stimulated the Protestants to claim that their reformed churches were the true churches and that rulers were divine agents to deliver and protect the peace of God's church.

The apocalyptic tradition had developed in the Protestant background. The

\footnotetext{
13 Ronald J. VanderMolen, 'Providence as Mystery, Providence as Revelation: Puritan and Anglican Modifications of John Calvin's Doctrine of Providence', Church History 47, no. 1 (1978): 32-3.

${ }^{14}$ Jean Calvin, Commentary on the Book of the Prophet Isaiah, ed., William Pringle (Grand Rapids: Christian Classics Ethereal Library, 2007), 1:13, 4:196; Commentaries on the Book of the Prophet Daniel, ed., Thomas Myers (Grand Rapids: Christian Classics Ethereal Library, 2007), 2:275-6; Commentaries on the Epistles to Timothy, Titus, and Philemon, ed., William Pringle (Grand Rapids: Christian Classics Ethereal Library, 2007), 4; Commentaries on the Catholic Epistles, ed., John Owen (Grand Rapids: Christian Classics Ethereal Library, 2007), 6, 131-32, 239; Firth, The Apocalyptic Tradition in Reformation Britain, 1530-1645, 37.

15 Zakai, 'Reformation, History, and Eschatology in English Protestantism', 306.
} 
Protestant historiography was transferred to the English reformers. The great influences on the development of apocalyptic historiography before the Restoration were John Bale, John Foxe, Thomas Brightman and Joseph Mede. These Protestant authors wrote historically important works which were central to the development of the English apocalyptic tradition. Their apocalyptic interpretations of English history contributed to millennial expectations during the Civil Wars, and even in the later seventeenth century many clergymen tacitly accepted or, at least, did not reject this tradition. $^{16}$

John Bale (1495-1563) was concerned with the apocalyptic account of human history during his first exile from England during Henry VIII's ecclesiastical reform. ${ }^{17} \mathrm{He}$ read some commentaries by theologians who had dealt with apocalyptic thought, and then wrote the first commentary on the Apocalypse. No later than 1545, he published a lengthy work titled The Image of Both Churches brought out in several parts which were published in 1541, 1545, and 1547. During his exile in the Low Countries, Bale read some commentaries on the Apocalypse by Wyclif and Joachim, and Joachim's apocalyptic thought especially influenced his own views. ${ }^{18}$ Following Joachim of Fiore, in his Image, Bale accepted the interpretation that a progression of seven epochs illustrated in the prophecies occurred within the history of the Christian Church. ${ }^{19}$ In his work, Bale deciphered the seven seals and trumpets in the Book of Revelation and asserted that the seven seals meant seven periods of Church history and that the true church emerged in the fifth seal. According to him, the fourth and fifth seals and trumpets represented respectively the false church and the true church. In the time of the fifth trumpet, the tyrannical Catholic Church dominated the world and his own time was placed in the period of the sixth seal in history. The sixth seal introduced the Reformation and the true spirit. ${ }^{20}$ Of most concern to Bale was Antichrist. Like Calvin, Bale believed that Antichrist appeared in conjunction with the commencement of the papal dominance which had gradually corrupted and deviated from the apostolic church. He did not

\footnotetext{
16 Ibid., 307.

17 John N. King, 'John Bale (1495-1563)', in Oxford Dictionary of National Biography (2004).

18 Gordon McMullan and David Matthews, eds., Reading the Medieval in Early Modern England (Cambridge: Cambridge Univ Press, 2009), 59.

${ }^{19}$ Firth, The Apocalyptic Tradition in Reformation Britain, 1530-1645, 40-1.

${ }^{20}$ John Bale, 'The Image of Both Churches', in Select Works of John Bale, D.D., Bishop of Ossory: Containing the Examinations of Lord Cobham, William Thorpe, and Anne Askewe, and the Image of Both Churches, ed., Henry Christmas (Cambridge: Cambridge University Press, 1849), 347-49, 350-53, 358-62; Firth, The Apocalyptic Tradition in Reformation Britain, 1530-1645, 42.
} 
wish to explain the emergence of the Antichrist by the invisible process of the 'mystery of iniquity but tried to define it in historical terms'. In the third part of the Image of Both Churches, Bale demonstrated how the Roman Church had been the Antichrist since the time of Pope Sylvester II. According to Bale, the Roman Church represented the spirit of Antichrist by seducing multitudes into infidelity and idolatry from around A.D. 600 by which point the papacy under Pope Boniface III reflected a growing corruption coinciding and in conjunction with the rise of the Saracens and Turks. $^{21}$

Another of Bale's concerns was the interpretation of the millennium in the twentieth chapter of Revelation. The millennium he understood as eternity and not as an exact number of years. He had no great expectation of the millennium nor did he place much emphasis on the reign of the saints with Christ on earth. Rather, he thought that spiritual renovation was more important than the physical aspect of the fulfilment of the prophecy. Bale argued that the starting point of the millennium could be seen in the Reformation. ${ }^{22}$

Bale's contribution to Protestant historiography was that his method of historiography argued that history or historical texts should be reinterpreted in the context of the apocalyptic fulfilment of the prophecies. ${ }^{23}$ It is obvious that Bale thought that the mysteries of the scriptures were evident in historical chronicles. Although Bale valued both biblical prophecies and historical records, the chronicles, he argued, should be interpreted in the light of the prophecies: 'Yet is the text a light to the chronicles, and not the chronicles to the text'. ${ }^{24} \mathrm{He}$ believed that the prophetical events depicted in the scriptures had revealed what would happen in Church history. Not only did Bale mark the beginning of apocalyptic historiography for the English Protestants, but he also set forth the new interpretation of the origin of the Church of England. According to Bale, the Church of England was founded not by St. Augustine of Canterbury whom Pope Gregory the Great sent to England in 597, but by St. Joseph of Arimathea. In doing so, he based the origin of the Church of England upon the apostolic tradition. This assertion thus implied that the English

21 The Apocalyptic Tradition in Reformation Britain, 1530-1645, 50, 54-5.

22 Ibid., 55-6; Avihu Zakai, Exile and Kingdom: History and Apocalypse in the Puritan Migration to America (Cambridge: Cambridge University Press, 1992), 21-2; 'Reformation, History, and Eschatology in English Protestantism', 308.

${ }^{23}$ Firth, The Apocalyptic Tradition in Reformation Britain, 1530-1645, 57.

${ }^{24}$ Bale, 'The Image of Both Churches', 253; F. J. Levy, Tudor Historical Thought (San Marino: Huntington Library, 1967), 87. 
Church was the true church, while the Roman Church which also stemmed from the apostolic church had become corrupted and superstitious. ${ }^{25}$ Bale's apocalyptic ideas and his prominent efforts in the development of Protestant historiography were continued in the work of his fellows and successors.

The apocalyptic tradition in England was preserved and developed in particular by John Foxe (1516-1587). During his exile to the continent, Foxe was influenced by the intellectual scholarship of European Protestants. The scholarly exchanges between the Marian exiles and the continental Protestants, in part, helped English Protestants like Bale and Foxe to establish the Protestant apocalyptic tradition. ${ }^{26}$ Foxe's development of the Protestant historiography is seen in his books, Commentarri Rerum in Ecclesia Gestarum in 1554, Rerum in Ecclesia Gestarum in 1559, and Acts and Monuments in 1563. His lengthy work, the Acts and Monuments was much influenced by Bale's writing of providential history. ${ }^{27}$ Like Bale, Foxe's apocalyptic work focused upon placing apocalyptic visions in the prophecies within history in order to justify the Reformation and reject the Roman Church. Foxe understood that the seven seals were matched to historical events from the time of Christ to the end of the world. The first seal signified the punishment of the Jews, and the second seal the judgement of pagan persecutors. The first four seals were placed before Antichrist's appearance. The fourth and fifth seals showed Antichrist taking over the Church while the true church was persecuted. The defeat of Antichrist would be seen in the sixth seal followed by the seventh as the Last Jugement. ${ }^{28}$ Persecution was a key notion in Foxe's apocalyptic thought. Foxe understood the process by which the true church was built up on earth in terms of the persecution of the faithful and the resurrection of martyrs. For Foxe, the persecution of Protestants under the reign of Mary and during Elizabeth's religious settlement was an important sign of the triumph of the true church. Foxe divided the history of church into three stages: the first covered the period from the persecution against the primitive church to the reign of Constantine; the second began with the thousand years of the binding of Satan from the conversion of Constantine to the beginning of persecution against

\footnotetext{
${ }^{25}$ Zakai, 'Reformation, History, and Eschatology in English Protestantism', 308; Levy, Tudor Historical Thought, 91.

${ }^{26}$ Firth, The Apocalyptic Tradition in Reformation Britain, 1530-1645, chap. 3.

27 Zakai, 'Reformation, History, and Eschatology in English Protestantism', 309.

28 Johnston, Revelation Restored: The Apocalypse in Later Seventeenth-Century England, 7; Firth, The Apocalyptic Tradition in Reformation Britain, 1530-1645, 83-4.
} 
the faithful under the Roman Church and Ottoman powers; the third was synchronised with the loosing of Satan and the consequent reign of Antichrist. Foxe's periodisation of the binding and loosing of Satan changed. In the 1570 edition of Acts and Monuments, he thought that the binding of Satan took place from the resurrection of Christ to A.D. 1000. In the 1583 edition, however, he placed the binding of Satan between the time of Constantine and the persecution of Wycliff and Huss after $1300 .^{29}$

Protestant historiography as presented by Bale and Foxe showed that the prophetical story could be visibly achieved in secular history. Following Bale, Foxe continued to advocate the apocalyptic role of England in prophetical history although he strongly promoted the idea of England as a nation among other European Protestant countries elected by God for a providential purpose. ${ }^{30}$ These two thinkers brought apocalyptic scheme into secular history and thus enabled English Protestants to anticipate the fulfilment of divine prophecy on earth. This thinking was accepted by many, including Thomas Brightman.

The Bedfordshire clergyman Thomas Brightman (1562-1607) wrote a commentary on Revelation, A Revelation of the Revelation (1615), to refute the apocalyptic ideas of Jesuit polemicists like Bellarmine and Ribena. Brightman developed the framework of apocalyptic historiography that his predecessors had built up by relating the image of the seven churches in the first three chapters of the Revelation to historical churches. He believed that the seven churches corresponded to churches throughout history. The church of Ephesus, argued Brightman, stood for the apostolic church from the preaching of the Apostles to the time of Constantine, Smyrna covered the period from Constantine to around 380. The church of Pergamus was associated with the Roman church until the year of 1300, and Thyatira with the period from 1300 to 1520 . Brightman did not view all Protestant churches as one Protestant body but as separated one from other in accordance with the prophetic structure of the seven churches. According to his scheme, the second wave of reformed churches of France, Scotland, Switzerland and Holland, following the pattern of Geneva, represented the church of Philadelphia and its primitivistic return

\footnotetext{
29 Johnston, Revelation Restored: The Apocalypse in Later Seventeenth-Century England, 7-8; Firth, The Apocalyptic Tradition in Reformation Britain, 1530-1645, 91-2; Peter Wickins, Victorian Protestantism and Bloody Mary: The Legacy of Religious Persecution in Tudor England (Bury St. Edmunds: Arena Books, 2012), 69.

${ }^{30}$ Firth, The Apocalyptic Tradition in Reformation Britain, 1530-1645, 109-10.
} 
to the apostolic church marked in the time of the Reformation. Brightman thought that this church began in 1519 when Ulrich Zwingli set out to preach at Zurich. ${ }^{31}$ On the other hand, the Lutheran church was recognised as the image of the church of Sardis implying that the Lutheran church was the first reformed church, 'begun by the special providence of godly Martin Luther at Wittenberg', but that its doctrines in part 'retained much of the heathenish superstition'. ${ }^{32}$ The church of Laodicea signified the third reformed church, the Church of England. For him the Church of England had been lukewarm in its faith and made 'a mingle-mangle of the Popish government with pure doctrine'. ${ }^{33}$

Following Foxe, Brightman associated the image of seven trumpets with the activities of the Antichrist against the true church. The period of the first four trumpets was before 607 when the Antichrist gained total control of the Church. The three trumpets were described as double events: the army of Satan on the one hand, the faithful of the true church on the other. The woman in the chapter 11 of the Book of Revelation signified the true church from 300 to 1300.

Brightman's apocalyptic sense of the relation of prophecy to the historical church engendered the assumption that his age was the last period of the apocalyptic scheme. After many apocalyptic events, the Antichrist was expected to expire in 1686. Brightman prophesied that after the final destruction of Antichrist, Christ would govern the world with the saints. ${ }^{34}$ In fact, in Brightman's interpretation there were two millennia. The first covered between 300 and 1300 with the binding of Satan, and the second represented the reign of the saints until the defeat of Antichrist and the conversion of the Jews with the advent of the New Jerusalem. ${ }^{35}$ 'For now is the last Act begun', he wrote, 'of a most long and doefull Tragedy, which shall wholy overflowe with scourges, slaughters, destructions, but after this Theater is once removed, there shall come in worme of it a most delightfull spectacle of perpetuall peace, joined with abundance of all good things'. ${ }^{36}$ Brightman was convinced of the proximity of the millennium in his own lifetime. He had an important impact on

\footnotetext{
31 Thomas Brightman, A Revelation of the Revelation (Amsterdam, 1615), 109.

32 Ibid., 35-6, 53-4, 62, 73, 91-5; Paul Christianson, Reformers and Babylon: English Apocalyptic Visions from the Reformation to the Eve of the Civil War (Toronto: University of Toronto Press, 1978), 100-1.

33 Brightman, A Revelation of the Revelation, 137.

${ }^{34}$ Zakai, 'Reformation, History, and Eschatology in English Protestantism', 315-16.

35 Johnston, Revelation Restored: The Apocalypse in Later Seventeenth-Century England, 10-11; Firth, The Apocalyptic Tradition in Reformation Britain, 1530-1645, 174.

${ }^{36}$ Brightman, A Revelation of the Revelation, sig. a3v; Zakai, 'Reformation, History, and Eschatology in English Protestantism', 315.
} 
Protestant apocalyptic thought in the seventeenth century by his positioning of the millennium within the course of history. ${ }^{37}$

Joseph Mede (1586-1639) had also a strong expectation of a millennium in the future and had no less impact on English apocalyptic thought than Brightman. With the denial of the Augustinian amillennial tradition, Mede held millenarian convictions for which Brightman had paved the way. Like previous commentators, his understanding of the prophecies was also based upon the apocalyptic tradition that explained providential history through prophetic terms and images. ${ }^{38}$ In his first edition of Clavis Apocalyptica in 1627, translated into English by Richard More in 1643, Mede offered a detailed study of prophetic images and symbols. In his synchronisation of prophetic images, the most remarkable part was the application of the visions of the seven seals, seven trumpets, and seven vials. Mede applied the image of the first six seals to the period of time from the spread of the gospel through the apostles to the conversion of Constantine. The seventh seal occurred at the same time as the six trumpets were sounded; the six vials were poured when the sixth trumpet was sounded. The first six trumpets were related to the historical period of time from the death of Theodosius in 395 to the rise of the Ottoman Empire. ${ }^{39}$

Mede's interpretation of the individual chapters of the Revelation supported his hope for the millenarian future. According to Mede, the seventh trumpet, synchronised with the seventh vial, would begin the millennium. Mede thought that the fall of the Beast in chapters 14, 17, and 18 in Revelation, would occur with the vision of 144,000 and would be located within the seventh seal which was synchronised with the first six trumpets. The prophesying of two witnesses for 1260 days would occur before the seventh trumpet. Given that the times of the sixth trumpet was not yet ended, he thought that all events relating to the seventh trumpet would arise in the future. This synchronisation encouraged Mede's millenarian

\footnotetext{
37 Johnston, Revelation Restored: The Apocalypse in Later Seventeenth-Century England, 13; Zakai, 'Reformation, History, and Eschatology in English Protestantism', 316; Christianson, Reformers and Babylon: English Apocalyptic Visions from the Reformation to the Eve of the Civil War, 246.

38 Zakai, Exile and Kingdom: History and Apocalypse in the Puritan Migration to America, 57.

39 Johnston, Revelation Restored: The Apocalypse in Later Seventeenth-Century England, 11; Peter Toon, Puritans, the Millennium and the Future of Israel: Puritan Eschatology, 1600 to 1660 (Cambridge: James Clarke, 1970), 57-9; Rob Iliffe, “Making a Shew": Apocalyptic Hermeneutics and the Sociology of Christian Idolatry in the Work of Isaac Newton and Henry More', in The Books of Nature and Scripture: Recent Essays on Natural Philosophy, Theology, and Biblical Criticism in the Netherlands of Spinoza's Time and the British Isles of Newton's Time, eds., James E. Force and Richard H. Popkin (Dordrecht: Kluwer Academic, 1994), 56.
} 
interpretation of the seventh trumpet as representing the millennium of chapter $20{ }^{40}$ Based upon his synchronisation, the millennium would take place in the middle of the seventeenth century.

As an Anglican scholar, not only did Mede conceive of prophetic events in the Book of Revelation as referring to a series of events in the history of Christianity, but also associated this understanding with the millenarian expectations that the thousand years of Satan's binding would take place in the future and the glorious and heavenly kingdom would be established on earth. ${ }^{41}$ As mentioned above, Mede's millenarian conviction was built upon the works of previous commentators like Brightman. Although his hope for the inauguration of the millennium with the physical rule of the saints in the future was explicit in his work, his interpretation of the millennium was different from the literal interpretation of the prophecy. $\mathrm{He}$ believed that the rule of Christ was a spiritual not a physical event.

Mede's exploration of biblical prophecies fortified historicist and millenarian convictions in English apocalyptic thought from the 1640s. His explanation went on to influence the apocalyptic beliefs of others. While Brightman placed the millennium within the course of history, Mede projected its fulfilment into the future. His millenarian belief appealed to both English Puritans and Anglicans. Mede's apocalyptic interpretation was accepted in that his reputation as being the prominent apocalyptic thinker continued long into the late seventeenth century. Moreover, even after his death, many Englishmen did not hesitate to accept Mede's apocalyptic understanding of the scripture. This shows the impact his apocalyptic thought had made from the early 1640 s onwards.

The sixteenth-century Protestant apocalyptic understanding of history in support of the Reformation was the version most appealing to English minds in the seventeenth century. This does not mean, however, that all Englishmen shared the same type of apocalyptic belief. The strength and extent of their apocalyptic convictions varied and depended upon their views of church, faith, or human history. Accepting their predecessors' millenarian expectation, English Protestants actively pursued the idea of the millennium to come and England's role became central to the apocalypse. The English Puritan Thomas Goodwin could find no reason to doubt the

40 Jeffrey K. Jue, Heaven Upon Earth: Joseph Mede (1586-1638) and the Legacy of Millenarianism (Dordrecht: Springer, 2006), 104-6.

${ }^{41}$ Ibid., 24. 
belief that his age was the last time in prophetical history. 'This is the last time, Goodwin said, because it is the perfection of the other ... and therefore seeing these are the last days'. ${ }^{42}$ In the seventeenth century radical apocalyptic beliefs were often promoted by religious minorities such as the Fifth Monarchists. Thomas Venner, for example, the leader of this group, explained his apocalyptic convictions in an undated pamphlet of the time of the Restoration entitled A Door of Hope. Connecting apocalyptic images to historical events, Venner calculated that the three and a half years of the loosing of the devil began from 1656 to 1660 and the resurrection of witnesses would occur at the victory of the true Church and the defeat of Antichrist. ${ }^{43}$ On the other hand, more moderate Nonconformists and Anglicans were inclined to be interested in more generalized explanation of the apocalyptic worldview. They were impressed by Brightman or Mede's method of the study of history. The historiographical method of seeking apocalyptic meaning from history was adopted by many exponents of the apocalypse. Mede's exegetical framework, especially, influenced later seventeenth-century Protestants such as the Cambridge Platonist Henry More and the latitudinarian clergyman Gilbert Burnet. To a lesser or greater extent, the sixteenth-century apocalyptic polemicists still provided the inspiration for the relationship between biblical prophecies and history to those who sought to pursue apocalyptic expectations in the later seventeenth century.

\subsection{Apocalyptic Pattern: England the Godly Nation}

As the Reformation spread across Europe, Protestant apocalyptic historiography took a leading role in the religious and political struggles against the Roman Church. It is worth noting again, in particular, that a rising trend of an apocalyptic approach to the study of history from the late medieval ages engendered interest in national history. Once they had accepted the apocalyptic historiographical perspective which was epitomized by the Protestant reformers, it was reasonable to believe that the

\footnotetext{
42 Thomas Goodwin, 'Three Sermons on Heb., I, 1, 2', in The Works of Thomas Goodwin, ed., John Miller, vol. 5 (Edinburgh: J. Nichol, 1861), 533-34, cited in Zakai, 'Reformation, History, and Eschatology in English Protestantism', 316

43 Johnston, Revelation Restored: The Apocalypse in Later Seventeenth-Century England, 69-74; Paul J. Korshin, 'Queuing and Waiting: The Apocalypse in England, 1660-1715', in The Apocalypse in English Renaissance Thought and Literature: Patterns, Antecedents, and Repercussions, eds., Constantinos Apostolos Patrides and Joseph Anthony Wittreich (Ithaca, N.Y: Cornell University Press, 1984), 250; Bernard S. Capp, The Fifth Monarchy Men: A Study in Seventeenth-Century English Millenarianism (London: Faber, 1972).
} 
apocalypse would be firmly placed within the boundaries of time and space. ${ }^{44}$ For them the course of sacred history which was illustrated in the prophecies was connected with a certain place on earth. In Protestant thought the apocalyptic image of the New Jerusalem where God's providential plan was to be achieved did not only have spiritual implications but was also regarded as representing an actual human nation in the world.

Thus from the sixteenth century many Englishmen attempted to find the historical significance of English history in the light of the apocalyptic idea of the New Jerusalem. Marian exiles such as Bale, Foxe and others had contributed to the development of an English apocalyptic tradition that paralleled the prophetic narrative with the history of the English church. ${ }^{45}$ The English people were gradually convinced that England would play a key role in the fulfillment of divine providence. Protestants found it useful to employ this newly-invented apocalyptic historiography in order to resist Roman authority. Most English Protestants shared a belief in Roman Catholicism as the Antichrist, and this was an underlying idea of Protestant apocalyptic thought in the early modern period. ${ }^{46}$ During this period English historical writings began to interpret apocalyptic history in terms of the struggle between true and false churches. The English Protestants regarded the English church as a true and pure establishment through which the divine plan had been revealed.

The emphasis on the role of the English church among the Protestant churches in Europe was manifest in the apocalyptic interpretation of the historical context of the monarchical support for the establishment of the Church of England. In this context the Church of England and the prince could be justified as God's true agents who would play a special role in the fulfillment of prophecies. Elizabeth's religious support for the Church of England also invigorated the interpretation that the Church of English was a divine instrument whereas the papal authority was the tyrannical and superstitious Antichrist. The military victory over the Armada in 1588

\footnotetext{
44 Zakai, Jonathan Edwards' Philosophy of History the Re-Enchantment of the World in the Age of Enlightenment (Princeton: Princeton University Press, 2003), 169.

${ }^{45}$ For detailed explanation of Marian exiles and their intellectual activities in the continent, see Zakai, Exile and Kingdom: History and Apocalypse in the Puritan Migration to America, 25-40; Firth, The Apocalyptic Tradition in Reformation Britain, 1530-1645, chaps. 2, 3, 4 and 5.

${ }^{46}$ Peter Lake, 'The Significance of the Elizabethan Identification of the Pope as Antichrist', The Journal of Ecclesiastical History 31, no. 2 (2011): 161-62; Johnston, Revelation Restored: The Apocalypse in Later Seventeenth-Century England, 8.
} 
secured such convictions with respect to the special role of England in providential history. Significant events in England motivated patriotic apocalypticism. This anglocentric interpretation of apocalyptic ideas influenced both conformists and nonconformists in the seventeenth century.

As English Protestants employed apocalyptic thought in their criticism of Rome, they faced the question of the whereabouts of the true church was before Luther. Many tended to answer this by arguing that the Church of England inherited the true spirit of Christianity from the ancient church. Englishmen shared the idea that 'pure apostolic Christianity had been transferred intact to England well before the intrusion of the Church of Rome during the seventh century'. ${ }^{47}$ It is true that even before Henry VIII's reign some Englishmen had proclaimed an apocalyptic expectation of the true reformed church. Early advocates of the reformation of the church provided the embryonic and fragmentary form of the English apocalyptic tradition. ${ }^{48}$ The idea of struggle between two churches upon which English Protestants based the explanation of English history was explicit in Bale's exposition. Bale transformed St. Augustine's popular notion of the two cities into the two churches, governed by Christ and Antichrist respectively. His exposition of the two churches suggested that the false church, the Antichrist, represented the evil power throughout history whereas the true church, originating from the apostolic church had survived and maintained its spiritual purity. This enabled him justify the Reformation on the basis of the continuing and unbroken institutional tradition. The Roman establishment was denied due to his view of the papacy as the agents of Antichrist. Bale depicted those who had been persecuted by papal authority as the elect of the true church for the divine purpose. ${ }^{49}$ His chronological application of prophecies to church history echoed this dichotomy.

Bale thought that the true church was the spiritual rather than the physical or local and put little emphasis on the apocalyptic role of England in his Image of Bothe Churches. Likewise, Bale did not place a strong emphasis on the godly ruler's role in the Reformation. A godly magistrate might carry out and secure the divine reformation. However, Bale believed that the reformation would be completed by the

\footnotetext{
47 Zakai, Jonathan Edwards' Philosophy of History the Re-Enchantment of the World in the Age of Enlightenment, 171; Exile and Kingdom: History and Apocalypse in the Puritan Migration to America, 25.

${ }^{48}$ Christianson, Reformers and Babylon: English Apocalyptic Visions from the Reformation to the Eve of the Civil War, 13.

49 Ibid., 15-6.
} 
presence of the persecuted and oppressed in the final stage of apocalyptic history, rather than that of the Christian prince. ${ }^{50}$ Bale did not, therefore, go so far as to make the Church of England and the monarchy unique elements for the completion of the Reformation. On the other hand, however, it is true that his apocalyptic interpretation opened the way for the call for the special role of England in the Reformation. Bale's analysis of the origins of the Church of England consequentially offered the idea that the Church of England was a true apostolic church. After Bale, English Protestant apocalypticism flourished. The death of Mary and the succession of Elizabeth to the throne encouraged the Elizabethan Protestants to see Elizabeth I as a godly prince. With divine providence Elizabeth was expected to protect English Protestantism against Rome. Her reign was described as the glorious result of the cosmic struggle between the persecuted and papacy. ${ }^{51}$

Following Bale's interpretation of church history, Foxe used the periodization of church history in order to criticise the Roman Church. Like Bale, Foxe's basic assumption in historiography was that God's plan was to bring the victory of the true church against the false church. Foxe believed that the whole story of church history led to the destined triumph of a Protestant Church. In this context, Foxe could portray the Church of England in a positive way and provided a defence of the Christian monarchy, chosen by God to consolidate the Reformation. ${ }^{52}$ With the return of a pro-Catholic policy in the reign of Mary and the persecution of Protestants, English reformers felt the need to keep the apocalyptic tradition in their minds. Marian exiles like John Jewel and Edward Sandys appealed to the primitive church in their apocalyptic thought. Jewel thought that Rome had become corrupted and early Christianity was the ideal model which divine providence desired to be realised on earth. ${ }^{53}$ Foxe also put the reformed church in England in the ranks of the true apostolic church. Foxe stressed the unique role of England as the elect nation by examining the history of the English church from the apostolic times to the Elizabethan period. ${ }^{54}$

Foxe's adherence to the reformed church was connected to the call for a

\footnotetext{
${ }^{50}$ Ibid., 19-20.

51 Ibid., 14, 33-5.

52 Ibid., 42.

53 Ibid., 42-5; George Kroeze, 'The Variety of Millennial Hopes in the English Reformation' (Ph.D. dissertation, Fuller Theological Seminary, 1985), 90.

${ }^{54}$ Zakai, 'Thomas Brightman and English Apocalyptic Tradition', in Menasseh Ben Israel and His World, eds., Yosef Kaplan, Henry Méchoulan, and Richard H. Popkin (Leiden: Brill, 1989), 34.
} 
godly ruler. Foxe compared the beginning of Elizabeth's reign in 1558 to Constantine's conversion and the official approval of Christianity. In the 1563 edition of the Acts and Monuments, Constantine was described as a protector of the true church. Likewise, Elizabeth was described as the second Constantine in English history. Foxe wrote that 'God's pitiful grace sent us your Majesty to quench firebrands, to assuage rage, to relieve innocents' ${ }^{55}$ In some ways Elizabeth was a better prince than the Roman emperor because Constantine was 'only but a helper unto the persecuted', whereas Elizabeth 'hath dispatched that persecution from other, under whiche ye were entangled your selfe'. ${ }^{56}$ Furthermore, Foxe stressed that Constantine was born in Britain. In his dedicatory preface of the Acts and Monuments to Elizabeth, Foxe also argued that Constantine's mother, Helena, was a daughter of an English king. ${ }^{57}$ This strengthened the implication of the role of England in church history. Foxe's apocalyptic thought was full of praise for the godly ruler who helped the true church free from antichristian persecution. This comparison enabled him to argue that the true reformation of Christianity could be carried on under a godly magistrate in England. ${ }^{58}$ Foxe even opened the second volume of the Acts and Monuments with a titlepage illustration of Henry VIII to show the royal supremacy over the Church of England as an apocalyptic triumph against Papal authority.

Not all apocalyptic writers set forth apocalyptic thought in order to promote the godly prince. Some Protestants questioned the divine role of the established Church of England and the prince. They even thought that the Established Church of England was governed by the Antichrist, or, if not, was a branch of the corrupt Catholic Church. Some Puritans who were associated with presbyterian or congregational groups audaciously condemned the Church of England as a branch of Babylon. They thought the only way to complete the true reformation in England was to make a break with the Church of England. ${ }^{59}$

Thomas Brightman was one of those who were disappointed by the progress of the Reformation in England. Despite the fact that he was influenced by Foxe's

\footnotetext{
55 John Foxe, The Acts and Monuments (London, 1563), sig. b2r, 41.

56 Ibid., sig. b3v.

57 V. Norskov Olsen, John Foxe and the Elizabethan Church (London: University of California Press, 1973), 184.

58 Zakai, Jonathan Edwards' Philosophy of History the Re-Enchantment of the World in the Age of Enlightenment, 180; John N. King, Foxe's Book of Martyrs and Early Modern Print Culture (Cambridge: Cambridge University Press, 2011), 95.

${ }^{59}$ Kroeze, 'The Variety of Millennial Hopes in the English Reformation', 106-7.
} 
arguments, he presented a different view concerning the role of the Church of England and the monarchy. 'Towards the end of James I's reign', as William Lamont argues, 'Foxe's view of the Christian prince seemed old-fashioned' to Brightman. ${ }^{60}$ He agreed with the previous apocalyptic writers' view that England had been blessed by God's providence, writing that,

... there can be nothing more cleare then the extraordinary goodness of God towards us ... for these forty and two yeares and more what great abundance of all good things hath he poured upon this Island of our? He hath given us a most gracious Queene, so excelling in all things that are praise-worthy, as the like to her no age ever saw; together with her hath hee graunted us peace. $^{61}$

Brightman, however, did not anticipate too much of apocalyptic significance from the Church of England or from the magistrate. As Brightman faced the problems of the incomplete Reformation in England towards the end of the sixteenth century, he was willing to reassess the monarchical reformation of the English church. He lamented that the reformed church in England had gone wrong. He thought the decline of the Church started from Constantine because the emperor brought heathen cruelty and savageness into Christianity. Likewise, for him, even if Elizabeth managed to protect the true church against Antichrist, the Protestant prince had failed to fulfil in her duty of achieving true reformation. His analogy between Constantine and Elizabeth was used in a different way from that of Foxe. In Brightman's eyes, Constantine freed persecuted Christians and converted himself to Christianity. However, the Church was corrupted not long after a time of 'but halfe an hour long'. The idea of the godly ruler was less appealing to Brightman than to Foxe. ${ }^{62}$ Brightman did not think that the Church of England succeeded in carrying on the reformation of the church. One of his remarkable discoveries was the identification of the Church of England with Laodicea in Revelation. In the parallel with the Laodicean Church, the Church of England represented lukewarmness. Even though the Church of England was founded upon Protestantism, Brightman argued, the reformation of the Church had remained incomplete. Furthermore, he warned that the Church of England because its unwillingness to reform would bring God's wrath

\footnotetext{
${ }^{60}$ William M. Lamont, Godly Rule: Politics and Religion 1603-60 (London: Macmillan, 1969), 52.

${ }^{61}$ Brightman, A Revelation of the Revelation, 127, 363.

${ }^{62}$ Lamont, Godly Rule: Politics and Religion 1603-60, 51.
} 
upon England. For him the Church of England did not completely break from Rome. 'The temporinge of pure doctrine and Romish regiment', wrote Brightman, 'maketh this lukewarmenes whereby wee stand just in the middest ... between the Romish and the Reformed Churches'. ${ }^{63}$ Brightman's criticism of the Church of England was drawn into the further reform of the church based not upon an episcopal model but upon an presbyterian model. ${ }^{64}$ In his interpretation of the seven churches of the Book of Revelation the Church of England was identified with Laodicea while the Swiss, Scottish, and French Protestant churches were depicted as Philadelphia. This implied that the basis for a justification of the Church of England as the true church was lacking. Brightman feared that the Church of England had deviated from Christ's teachings, so he warned that it would suffer punishments in the future.

Brightman's was not the only criticism that arose against the Church of England and the monarchical protection of the Church. The limits of the Elizabethan settlement and James I's hostile attitude towards Dissenters had discouraged Brightman and his followers. His distrust of the Church of England and of the monarch influenced the minorities who argued an alternative Protestant church could replace the corrupted Anglican Church for the fulfilment of divine purposes. ${ }^{65}$ Following Brightman, puritans who rejected Anglican liturgy and wished to abolish the Church of England in the early seventeenth century longed to restore true reformation under presbyterian government. ${ }^{66}$

However, for all the apocalyptic language used against the Elizabethan church and the prince, the need for an apocalyptic rhetoric in vindication of the English Reformation remained until the later sixteenth-century. There were variations of apocalyptic interpretations of the role of the English prince but the sixteenthcentury reformers were all agreed on the concept of England as an elect nation. They still believed that God had a providential plan for England. This idea was an apocalyptic product of the thought of the sixteenth-century English Protestants like Bale, Foxe, Brightman and others. For Foxe, the early reign of Elizabeth represented the apocalyptic destiny of England as the elect nation. ${ }^{67}$ Brightman also believed

\footnotetext{
63 Brightman, A Revelation of the Revelation, 132.

${ }^{64}$ Johnston, Revelation Restored: The Apocalypse in Later Seventeenth-Century England, 10.

${ }^{65}$ Michael P. Winship, Godly Republicanism Puritans, Pilgrims, and a City on a Hill (Cambridge, Mass.: Harvard University Press, 2012), 64-5, 67.

${ }^{66}$ Kroeze, 'The Variety of Millennial Hopes in the English Reformation', 126, 153.

${ }^{67}$ Zakai, 'Thomas Brightman and English Apocalyptic Tradition', 34-5.
} 
that political events in England represented the final stage towards the perfection of prophecies. For him the Elizabethan Reformation against Rome evinced the belief that God made use of human instruments to achieve his promise. ${ }^{68}$ In addition, Brightman's belief in the rule of the saints provided an impetus to the perception of the special role of England. ${ }^{69}$ In line with Bale and Foxe, Brightman did have some hope that the Church of England and Elizabeth as the prince would carry out the judgment of God by removing the vestiges of Catholicism in England. During the sixteenth and seventeenth centuries Englishmen viewed England as the central nation in providential history. The idea of England's prominent role was developed in both components of early modern apocalyptic thought: 'sacred history' and 'sacred place'. ${ }^{70}$ The Church of England could be regarded as a true church and England could be entitled a chosen nation as long as English Protestants were committed to apocalyptic thought.

Sixteenth-century English apocalyptic writers influenced the creation of the seventeenth-century apocalyptic tradition. Not only did radicals like the Fifth Monarchists embrace the ideas of the sixteenth century, but Anglicans also accepted this tradition in order to pursue the anti-popery rhetoric. Many Englishmen were conscious of being within the apocalyptic tradition. ${ }^{71}$

The sixteenth-century English apocalypticism intrigued the erudite scholar Joseph Mede. Mede followed the basic framework of the English apocalyptic tradition. Using the synchronism of prophecies, Mede based his interpretation of prophetical images upon the struggle between the antichristian false church and the true church. Basically Mede believed that the failure of the Spanish Armada campaign in 1588 and the independence of the Dutch in 1609 were part of the divine plan for England to play an important role in the apocalyptic victory over Rome. In the apocalyptic war, those who supported papal authority would be defeated during the reign of Elizabeth and afterwards. Identifying the images of the first six vials with the historical process of the fall of Antichrist, Mede placed the Elizabethan religious settlement in the period of the third vial in which God's judgment was

\footnotetext{
68 Toon, Puritans, the Millennium and the Future of Israel: Puritan Eschatology, 1600 to 1660, 77-8.

69 Johnston, Revelation Restored: The Apocalypse in Later Seventeenth-Century England, 13; Christianson, Reformers and Babylon: English Apocalyptic Visions from the Reformation to the Eve of the Civil War, 100; Zakai, 'Thomas Brightman and English Apocalyptic Tradition', 38.

${ }^{70}$ Zakai, Exile and Kingdom: History and Apocalypse in the Puritan Migration to America, 59.

71 Ibid., 77.
} 
given upon the antichristian army. Although the ministers and defenders of 'the Antichristian jurisdiction' like the Jesuits advanced the Roman cause, 'those bloody Proctors for the authoritie of the Beast' were punished 'for soliciting the Papall cause'. 72

Like Brightman, Mede was convinced of the millennium in the approaching age. These two Protestant writers opened the way for seventeenth-century millenarianism. The early seventeenth-century Puritans were disappointed at the reformation of the English Church and thus advocated the radical version of millenarianism. They had read Brightman and Mede's apocalyptic writings which influenced Puritan millenarianism. Many historians have argued for Mede's influence on extreme millenarianism. ${ }^{73}$ Many radical sects saw Mede's apocalyptic interpretation as a satisfactory justification of their religious campaign during the early seventeenth century. It is true that the high expectation of the millennium to come soon enabled many to expect extreme activities during the early seventeenth century. The Fifth Monarchists led by Thomas Venner, for example, insisted that the year of the Second Coming would be 1666 and attempted to welcome it in by violent means. Following Mede, John Milton showed his belief in the millennium during the $1640 \mathrm{~s}$ and 50s. ${ }^{74}$ These millenarianists were in agreement with Nonconformists who rejected the external forms of worship used by the Church of England because they viewed them as idolatrous and inconsistent with principle of the Scripture. ${ }^{75}$

Contrary to some millenarian radicals, however, Mede's apocalyptic thought supported a commitment to the Church of England. He developed anti-papal rhetoric in order to justify the Church of England. Mede felt the necessity for outward forms of worship. He wrote a couple of treatises demonstrating that the practices of the Church of England were guaranteed by the Bible. In his commentary on John 4: 23, he rejected the Puritan criticism of the Church of England and upheld the practices established by the Church. He held that to argue that 'the worship of the Gospel should be onely spiritual, and no external worship required therein ... is repugnant not onely to the practice and experience of the Christian Religion in all Ages, but

\footnotetext{
72 Joseph Mede, The Key of the Revelation (London, 1643), part 2, 116.

73 Jue, Heaven Upon Earth: Joseph Mede (1586-1638) and the Legacy of Millenarianism, 20.

74 Juliet Cummins, Milton and the Ends of Time (Cambridge: Cambridge University Press, 2003), 3; Stephen Hunt, Christian Millenarianism: From the Early Church to Waco (London: Hurst, 2001), 84; Firth, The Apocalyptic Tradition in Reformation Britain, 1530-1645, 232-33.

75 Jue, Heaven Upon Earth: Joseph Mede (1586-1638) and the Legacy of Millenarianism, 21; Dai Liu, Discord in Zion: The Puritan Divines and the Puritan Revolution, 1640-1660 (The Hague: Nijhoff, 1973), chap. 2.
} 
also to the express Ordinances of the Gospel itself'. In doing so, Mede concluded that 'to worship God without Rites and Ceremonies, is not to worship him in spirit and Truth, according to the meaning here intended'. ${ }^{76}$ Mede clearly maintained the doctrines of the Church of England and rejected other forms of church government like congregationalism or Presbyterianism. ${ }^{77}$ This indicates that his millenarianism endorsed the role of the Church of England in apocalyptic history as the true church.

The emphasis on England as a special nation in the apocalyptic drama continued to develop throughout the seventeenth century. The seventeenth century witnessed the proliferation of the legacies of Foxe, Brightman, and Mede. English apocalyptic historiography became deeply associated with English national history through the prominent apocalyptic exegetes. The seventeenth-century Anglicans surveyed ecclesiastical history from the Reformation to the Church of England and traced the origins of the reformed church to apostolic times. English apocalyptic historiography would remain powerful even after the Restoration because of its usefulness for the fight against Catholicism.

\subsection{The Cambridge Platonists' Apocalypticism}

After the publication of Mede's works, English apocalyptic ideas became attractive to many Englishmen. From the early seventeenth century the degree to which millenarianism was accepted by English Protestants varied. Anglicans admitted that their apocalyptic interpretations were mainly influenced by Mede. John Worthington, a close associate of the Cambridge Platonists, collected and published Mede's treatises and prefaced his collected works in $1664 .^{78}$ In his preface, Worthington attempted to place Mede within the Anglican apocalyptic tradition, asserting that Mede's commentaries were far removed from the irrational prophetic interpretation of the radicals. Worthington asserted that the study of prophecies needed to be based upon 'a right understanding of the genuine meaning of these Prophetick Visions'. In this sense, Worthington admired Mede's skill in the application of prophetic events to history. ${ }^{79}$ Henry More (1614-87), one of the prominent Anglican polemicists, also

\footnotetext{
${ }^{76}$ Mede, The Works of the Pious and Profoundly Learned Joseph Mede, ed., John Worthington (London, 1664), 63-5.

77 Jue, Heaven Upon Earth: Joseph Mede (1586-1638) and the Legacy of Millenarianism, 22, 25.

${ }_{78}$ Mede, The Works of the Pious and Profoundly Learned Joseph Mede.

79 Ibid., preface, sig. ****3, ******2; Sarah Hutton, 'The Appropriation of Joseph Mede: Millenarianism in the 1640s', in Millenarianism and Messianism in Early Modern European Culture, Vol. 3, the Millenarian Turn:
} 
owed many of his apocalyptic ideas to Mede.

Even though the relationship between Joseph Mede and the Cambridge Platonists, and further, the latitudinarians has been mentioned, there is very little evidence for the intellectual connection between these intellectuals. ${ }^{80}$ Recently academic attempts to identify some intellectual similarities between Mede and the rational theologians have been made. Analysing Henry More's influence on a rational model for the latitudinarians, Robert Crocker argues that the Cambridge Platonists and the younger generation of the latitudinarians shared Mede's irenic and moderate Anglican tradition. ${ }^{81}$ Jeffrey K. Jue analyses the theological connections between Mede and the Cambridge Platonists. The Cambridge Platonists, Jue argues, had theological similarities with Mede in terms of the emphasis on natural theology, the criticism of Calvinism, and the doctrine of justice. Jue does not affirm a close link between Mede and the Cambridge Platonists, but he suggests that the contact between Mede and some Cambridge students would have given opportunity for Mede's theology to be circulated in their circle. ${ }^{82}$ In fact, most of the Cambridge Platonists were educated or held posts at Cambridge while Mede served as a fellow at Christ's College until his death in 1638. Benjamin Whichcote (1609-83) started his educational career at Emmanuel College in 1626, and tutored John Smith (1616-52), who enrolled in 1636, and John Worthington (1619-51), who was the editor of Mede's works. Ralph Cudworth (1617-88), who enrolled at Emmanuel in 1632, was a classmate of Worthington and Smith. When Whichcote was elected Provost at King's College in 1644, Smith became a fellow at Queen's. Given that the Cambridge Platonists shared much of their academic careers in Cambridge with Mede, it is plausible to assume that they were well acquainted with him. ${ }^{83}$

It is difficult to discern what the Cambridge Platonists thought of the millennium. Except for Henry More, none of them, it seems, focused their attention

Millenarian Contexts of Science, Politics, and Everyday Anglo-American Life in the Seventeenth and Eighteenth Centuries, eds., James E. Force and Richard H. Popkin (Dordrecht Kluwer Academic, 2001), 9-10.

${ }^{80}$ Many historians have mainly questioned the impact of Mede on More's apocalyptic thought. See Ernest Lee Tuveson, Millennium and Utopia: A Study in the Background of the Idea of Progress (New York: Harper \& Row, 1964), 92-9; Philip C. Almond, 'Henry More and the Apocalypse', Journal of the History of Ideas 54, no. 2 (1993): 189-200; Robert Crocker, 'Henry More and the Restoration', Parergon: Australian and New Zealand Association for Medieval and Early Modern Studies 21, no. 2 (2004): 127-51; Sarah Hutton and Robert Crocker, eds., Henry More (1614-1687): Tercentenary Studies (Dordrecht: Kluwer Academic Publishers, 1990), 3-4.

${ }^{81}$ Crocker, 'Henry More and the Restoration', 131.

82 Jue, Heaven Upon Earth: Joseph Mede (1586-1638) and the Legacy of Millenarianism, 37-63.

${ }^{83}$ Ibid., 38-40; Isabel Rivers, Reason, Grace, and Sentiment: A Study of the Language of Religion and Ethics in England, 1660-1780, Vol. 1, Whichcote to Wesley (Cambridge: Cambridge University Press, 1991), 29. 
on the mystery of the apocalypse. However, although many of them did not give a detailed commentary on the biblical prophecies, they did have an apocalyptic sense of the future. It may be said that these Cambridge scholars shared the apocalyptic belief in a divine providential salvation in the future. For example, Whichcote claimed that God had protected all men by his 'special and particular providence' against Antichrist, whereas Satan had set up a snare to seduce human souls into apostasy. Whichcote stressed that God's providence always 'leads men to repentance'. ${ }^{84}$ Whichcote was not alone in the use of apocalyptic thought in encouraging the repentance of the sinners. Cudworth also maintained the hope that God would defend his people by 'pouring out of the Holy Ghost upon his Disciples, after his Ascension into Heaven', until the end of this world. ${ }^{85}$ John Smith saw the dragon in the Book of the Revelation as the devil who had been continually busy with corrupting men. Smith claimed that the evil was "not yet cast out of the world into outer darkness, though it be prepared for them: the bottomless pit hath not yet shut its mouth upon them'. Although Antichrist was still active, he would 'fall down as swift as lightning; he cannot bear the glory of God shining in the Souls of men', because 'The Devil and Sin in themselves considered are but weak and impotent; they cannot prevail over that Soul which yields not to them'. In conclusion, Smith anticipated the day of ultimate victory over evil, depicting that 'at that time we shall all meet with our dear Father and Friend again ... and there shall be no more death, neither sorrow, nor crying, neither shall there be any more pain'. ${ }^{86}$ These rational Anglicans attached apocalyptic rhetoric to the encouragement of repentance and exhortation of morality.

Henry More was the most notable of the Cambridge students influenced by Mede. More was a student at Christ's from 1631 and succeeded to a Fellowship after Mede's death. More's prolific career exhibited a broad range of interest in science, theology, and philosophy. The many studies of More's intellectual life reveal that his apocalyptic thought is remarkable. This is not only because his apocalyptic writings were just one part of his intellectual project of explaining Christianity as grounded upon rationality, but also because his apocalyptic interpretation influenced the

\footnotetext{
${ }^{84}$ Benjamin Whichcote, The Works of the Learned Benjamin Whichcote, vol. 1 (Aberdeen, 1751), 126, 261-65, 306, 321

85 Ralph Cudworth, A Sermon Preached to the Honourable Society of Lincolnes-Inne (London, 1664), 14.

${ }^{86}$ John Smith, Select Discourses, 2nd ed. (London, 1673), 448, 462-68, 526.
} 
following generation of the latitudinarians. His own apocalyptic thought was heavily dependent upon Mede. More often acknowledged Mede's contribution to his own interpretation of the prophecies. More constantly put forward apocalyptic views from the Restoration until his death. He admitted that he was 'assisted by several Interpreters, such as ... John Calvin, Hugo Grotius, and Joseph Mede', although Grotius was an influence only as a target of criticism. ${ }^{87}$ Among these Mede was the most important commentator for More. In his famous apocalyptic work, Apocalypse Apocalypseos in 1680, More depicted Mede as an 'incomparably Pious and Learned person'. ${ }^{88}$ More was an ardent writer who adopted Mede's apocalyptic interpretation. He referred to Mede as one:

whose proceedings are with that care and caution, with that clearness and strictness of reason, with that accuracy of judgement and unparallel'd modesty and calmness, that the study and enquiry into these matters, which had even grown odious and infamous by the wild and ridiculous miscarriages of hot fanatic spirits, has in my apprehension gained much credit and repute by the orderly and coherent methods and unexceptionable ratiocinations of this grave and venerable Person. Upon whose account I am not ashamed to process, that I think it clear both out of Daniel and the Apocalypse that the Scene of things in Christendome will be in due time very much changed, and that for the better. ${ }^{89}$

As More acknowledged, Mede's interpretative system was manifest in More's own explanations of the biblical prophecies. The fundamental structure upon which More's apocalyptic thought was built relied especially upon Mede's synchronisation of prophetic images. ${ }^{90}$ Like Mede, More believed that images of seven seals, vials, and trumpets illustrated the same history in different ways. In another apocalyptic work, An Illustration of Those who Abstruse Books in Holy Scripture (1685), he referred the first six seals to the period of Roman Empire until the conversion of Constantine to Christianity, and the period of the seventh seal involving seven trumpets he interpreted as ranging from the beginning of the church to the end of the world. Again, the seventh trumpet took up the same period as the seven thunders and seven vials. The pouring out of the first three vials he ranged from the reign of

${ }^{87}$ Henry More, A Plain and Continued Expeosition of the Several Prophecies (London, 1681), xv-xvi.

${ }^{88}$ More, Apocalypsis Apocalypseos; or the Revelation of St John the Divine Unveiled (London, 1680), 249.

89 More, An Explanation of the Grand Mystery of Godliness (London, 1660), 172.

90 Johnston, 'The Anglican Apocalypse in Restoration England', 192-93. 
Edward VI to the reign of James I, and the pouring out of the remaining four vials he reserved for the future. The fifth and sixth vials were interpreted as the dominance of 'the false pretence of the Papal Hierarchies Infallibility', 'a mutation of affairs in the Turkish Empire', and the conversion of the Jews. ${ }^{91}$

It must be recognised, however, that More's expositions of the apocalypse were not a simple repetition of Mede's. With some minor differences, More set forth a more developed version of the apocalypse. More, for example, explained that Mede placed all vials 'before the seventh Trumpet' and did not 'distinguish the seventh Trumpet into seven Thunders in his Table' so that he made 'the binding of Satan and Millennial Reign of Christ ... to commence immediately at the beginning of that Trumpet'. More linked the first thunder to the pouring out of the vials, the third vial to the millennium, and the last four to the final destruction of Antichrist and the end of the world. ${ }^{92}$

More's apocalyptic interpretation was focused upon the analysis of history in terms of the apocalypse. He also was influenced by the apocalyptic tradition of the sixteenth-century apocalyptic commentators used in placing historical events within the providential framework. According to More, it was after the conversion of Constantine in 432 that Christianity had begun to suffer from antichristian tyranny. The period of the reign of Antichrist was 1260 years because More interpreted the 42 months of the rising of the beast from the sea as 1260 years $(42 \times 30$ prophetic days, with a prophetic day begins the same as a year). Therefore the destruction of Antichrist was at hand. For More the period of antichristian dominance corresponded to that of the papal domination of Europe. ${ }^{93}$

Anti-papal polemic was one of the prominent features of More's apocalyptic writings, and formed the central element of his exposition. In his exegesis of the prophecies of Daniel and Revelation, More identified Roman Catholicism with Antichrist, labelling the pope as the 'beast', 'the Whore of Babylon', and the 'dragon', and so forth. ${ }^{94}$ The reason why the Roman Church was dubbed with these pejorative titles, for him, was evident. More asserted that 'the likeness of similitude

${ }_{91}$ More, An Illustration of Those Who Abstruse Books in Holy Scripture (London, 1685), 236-65, 307-17.

92 More, Apocalypsis Apocalypseos; or the Revelation of St John the Divine Unveiled, 259; Johnston, Revelation Restored: The Apocalypse in Later Seventeenth-Century England, 29-30.

${ }_{93}$ More, Synopsis Prophetica; or, the Second Part of the Enquiry into the Mystery of Iniquity (London, 1664), 365.

94 See, ibid., chap. 4 and 11; Apocalypsis Apocalypseos; or the Revelation of St John the Divine Unveiled, chap. 12. 
that the state of the Roman Church bears to ancient Paganism in Idolatry, Superstition and Cruelty is so complete ... that I cannot but devoutly admire the exact veracity of these Divine Visions in so material a Prediction'. More did not only refer to the images of the pope, but explained the natures of 'Antichrist' in detail. According to him, Antichristianity consisted of two things:

First, in the instituting of such Laws, or authoritatively teaching such Doctrines, and promoting or commanding such practices, as naturally defeat and frustrate the true scope and purpose of the Gospel of Christ. And then Secondly, In the doing this with such artifice and so fair pretences, that they bear the world in hand in the mean time that they are doing the work of God, and promoting the Interest of the Kingdom of his Son Jesus. ${ }^{95}$

For More the first feature of Antichrist was idolatry in that the 'Sacerdotal Hierarchy' imposed a false way of worshipping God. For example, he enumerated the idolatrous practices of worship, including 'the Religious worship of the Cross, as also the Image of God the Father, Son, or Holy Ghost; the devotional invocation of the blessed Virgin, or any other Saints, or Angels; the worshipping of their Pictures, or Images ... and lastly, the adoration of the consecrated Bread in the Eucharist upon the imagination that it is transubstantiated into the very body of Christ' ${ }^{96}$

Also, said More, Antichrist made 'himself so absolute a Head of the Church', and cut off Jesus from being the Head of the Church, and then, in doing so, placed 'himself to be the notorious Antichrist in Christendom', while pretending to be eager to do the work of God. ${ }^{97}$ Antichrist was, he confessed furthermore, 'more oblique and more subtil', and hence, 'it is no wonder that their Antichrist ... not a gross and violent Invader of the Empire of Christ, but a more cunning Impostour and insinuating Hypocrite'. 98

More's anti-papal concern, however, was not radical. He did not categorise the whole history of Christianity up to the Reformation as an antichristian period, but rather believed the purity, charity, and simplicity of the primitive church to be restored. In his calculation of the period of the reign of Antichrist, which was 1260 years, More drew a distinction between the pure Christian in the apostolic Church and the 'Rome pagano-christian', and was convinced that the Church had not become

\footnotetext{
95 More, Synopsis Prophetica; or, the Second Part of the Enquiry into the Mystery of Iniquity, 335.

${ }^{96}$ Ibid., 209.

97 Ibid., 208.

98 Ibid., 209.
} 
antichristian until around A.D.400, until which time it had been 'symmetral'. 99 For More, this manifested the link between the Roman church and the Roman Empire. He spent many pages explaining the connection of the Roman Catholic with the Roman Empire showing the process in which Roman paganism brought the Church of Rome into corruption and thus the Church became idolatrous and antichristian. The Christianity from the reign of Julius up to that of Constantine was the primitive church. But after the conversion of Constantine, A.D.432, the empire became 'Paganochristian', imposing 'the old Paganick Idolatries upon the people' under the pretence of Christianity. Hence with the assistance of the dragon the church became 'the worshipper of Devil'. ${ }^{100}$ In doing so, More understood the 'Whore of Babylon' or the 'two-horned beast' as the pope who had also imperial power as an emperor and controlled both political and religious power.

Apocalyptic historiography provided More with a strong weapon for justifying the Church of England. In his writings the analysis of apocalyptic history ultimately led to the hope of the demolition of the papal hierarchy. In addition to this, historical events, like the Reformation and the Restoration, had allowed him to believe in the veracity of the apocalypse. But this was not the end of the apocalyptic story. More sought to understand his own time through the mirror of apocalyptic interpretations. As with other millenarian interpreters, his anti-papal conviction needed to be understood within his narrative of church history. This informed him that despite overwhelming antichristian power, divine providence had preserved the apostolic church; that the Antichrist was destined to be destroyed by divine providence; that the hand of God would rule the kingdom of all true Christians.

In his Exposition of the Seven Epistles to the Seven Churches (1669), More stressed that the Episcopal Church was the best and most apostolic government. $\mathrm{He}$ claimed that the epistles to the seven churches referred to a series of the states of the church throughout history. More saw these seven states in the prophecy of Revelation as representing the history of Christianity from the beginning of the primitive church to the church of the New Jerusalem. ${ }^{101}$ As considering the historical time of the seven churches, he paid particular attentionto the states of the last three churches,

\footnotetext{
99 Almond, 'Henry More and the Apocalypse', 194.

100 More, Apocalypsis Apocalypseos; or the Revelation of St John the Divine Unveiled, 125-26, 172.

101 Cf. More, An Exposition of the Seven Epistles to the Seven Churches Together with a Brief Discourse of Idolatry (London, 1669).
} 
Sardis, Philadelphia, and Laodicea, because for him the Sardis church referred to the state of Reformed Christendom when the Church of Rome should be subdued; Philadelphia represented the time when 'Truth, Peace and Holinesse shall universally prevail, and the name of the New Jerusalem shall be written upon the Church'; lastly, Laodicea referred to the time 'when towards the end of the Thousand years Satan shall be again let loose a little space', but will be defeated. He was convinced that the state of Philadelphia was not just an allegory, but meant the realisation of the reformed church and kingdom. So he argued that all the people were 'obliged to endeavour to promote the Interest of their Prince and Countrey whose affairs they administer'. ${ }^{102}$ This affirmed his support of the restored church and of the monarchy.

Also, more importantly, More focused upon the seventeenth chapter of Revelation in order to emphasise the importance of the resurrection of the two witnesses. He believed that, beginning before the onset of the Reformation, the witnesses' revival was fulfilled gradually over the course of the state of the Sardis church, initiating the fall of the papal hierarchy. Seeing the witnesses rising already 'in the late blessed Reformation', at the same time, said More, 'so great a part of the Roman Hierarchy had fallen in the late blessed Reformation', and was 'no longer permitted to seduce the people to commit fornication, and eat things sacrificed to Idols'. 103

Nobody would have better appreciated the usefulness of this vision of the two witnesses than Henry More. He realised the benefits he could draw from it. Firstly, he could argue that the church after the Reformation was an extension of communion of the primitive church with its virtues resurrected within the reformed church. $\mathrm{He}$ described 'all the Reformed Churches, States and Kingdomes, ... keeping to the old Orthodox Faith of the Triunity of the Godhead and Divinity of Christ, acknowledged by the Church in the Symmetral times thereof, and renouncing the Communion of the Roman Church for her gross Idolatries and wretched and intolerable Superstitions and humane inventions'. Secondly the identification of the Reformation with the rising two witnesses was used to contradict the radical argument of the Fifth Monarchy men. Lastly, and obviously, More found the image of the two witnesses could be used to disparage the Roman church, presenting the English church as the

\footnotetext{
102 Ibid., sig. a8r.

103 More, Apocalypsis Apocalypseos; or the Revelation of St John the Divine Unveiled, 108-9.
} 
true system of divine providence. ${ }^{104}$

There is no doubt that he ascribed to the prophecy of the two witnesses 'a peculiar Attestation to the Church of England'. ${ }^{105}$ By paying attention to the connection of the English church with the old church, he described the Established Church as 'reformed according to the old Symmetral and Apostolical Pattern'. So his support of the Church of England led him to see the true infallibility conferred on the established church by the primitive church which did not resist 'the Sovereign Power', and 'professed the truth of Christianity against the Vanities and Idolatries of Paganism'. ${ }^{106}$ For him, the victory of the primitive church against the false church was witnessed by the restored Church of England. By laying aside the accusation of 'schism' against the Church of England, that Church could therefore be seen as a bearer of the restored Catholic and apostolic faith.

For More the rise of the two witnesses implied the restoration of the authorities of the true church and of the godly ruler against the Antichrist. He also advocated the role of the civil ruler in the church by arguing that 'the two witnesses were an allusion to ... Magistracy and Ministry' ${ }^{107}$ With confidence he pronounced that 'in a Christian polity the power of appointing and ordering things in the Church is lodged in the Supremacy of every such Body Politick', so that 'this Supreme Power is to regulate the affairs of the Church' ${ }^{108}$ By placing the Reformation and the civil magistracy as the pivotal pillars of the two witnesses, More underlined the improbability of any subversion of the government. He asserted that 'Superior and Inferior are as natural in a people as Head and Feet in an humane body', and hence, 'no man can decry Government but out of madness or some villainous design'. ${ }^{109}$ In doing so, he was clearly supporting the existing systems of church and government in England.

The defence of the civil magistrate was conspicuous in More's interpretation of the apocalypse. In addition, the roles of the civil ruler were enumerated: the Christian magistrate was to 'give Liberty of Conscience to all'; to prohibit those people who were harmful to the safety of the country 'from bearing any Office of

\footnotetext{
104 More, A Plain and Continued Expeosition of the Several Prophecies, liv-lvii.

105 Johnston, Revelation Restored: The Apocalypse in Later Seventeenth-Century England, 480.

106 More, Paralipomena Prophetica: Containing Several Supplemenss and Defences of Dr H. More (London, 1685), x-xi, xvi.

107 More, Apocalypsis Apocalypseos; or the Revelation of St John the Divine Unveiled, 102-3.

108 More, An Explanation of the Grand Mystery of Godliness, xvii-xviii.

109 Ibid., 204.
} 
trust in the Commonwealth'; to give assistance 'for the defending and promoting of our Religion'; to 'suppress and keep under all Sects and Religions that hold of so Fanatick a tenour'; lastly, to 'continue and erect ... publick schools of Learning' to make his subjects to keep to Christianity, while the main end of Church-government was ought to promote the Christian life and keep out of 'idolatrous', 'erroneous', and 'superstitious practices'. ${ }^{110}$ The significant theme running throughout More's apocalyptic writings is the legitimisation of the secular magistrate and of the Established Church against all opponents. ${ }^{111}$

More was much indebted to Mede for his apocalyptic framework, but he advanced on Mede's argument. More's millenarianism was not understood in a mystical sense. It is important to note that More's writings relied on a rational interpretation of the prophecies. When he attempted to interpret the prophecy he used reasonable arguments to make sense of the mystical language of the prophecies. ${ }^{112}$ For him reason meant 'a Power or Facultie of the Soul, whereby ... her Innate Ideas or Common Notions, or else from the assurance of her own Sense', and by using it people would unravel knowledge, and thereby be able to deduce various conclusions. ${ }^{113}$ It was essential, he thought, to a grasp the foundation of gospel which was 'so intelligible a Truth ... built upon these undeniable Grounds' that there is a God and a perfect divine providence, and that there are angels, and so forth. ${ }^{114}$ As well as the Bible, moreover, nature, whose principles were discoverable by reason, was also suggestive of the existence of God. The reasonable deduction from the order and contrivance of nature reveals that there is an intellectual principle that is God. In the life of Christians, reason was 'illuminated in all Divine and Moral concernments', so that rational powers begot the truest ground of prudence in the soul. ${ }^{115}$

The proper reading of prophecies in More's apocalyptic thought was crucial for opposing not only the atheists but also the enthusiasts, among whom the Fifth Monarchy men, in particular, drew his fire. In the seventeenth century, the Fifth Monarchy men believed that the two witnesses would rise in the near future, and that

\footnotetext{
110 Ibid., xviii, 525-8.

111 Johnston, 'The Anglican Apocalypse in Restoration England', 482.

112 Hutton, 'More, Newton, and the Language of Biblical Prophecy', in The Books of Nature and Scripture: Recent Essays on Natural Philosophy, Theology, and Biblical Criticism in the Netherlands of Spinoza's Time and the British Isles of Newton's Time, eds., James E. Force and Richard H. Popkin (Dordrecht: Kluwer Academic, 1994), 45.

113 More, An Explanation of the Grand Mystery of Godliness, 51.

114 Ibid., 242.

115 Ibid., 55.
} 
the millennium would be brought about by the sword. ${ }^{116}$ As mentioned above, More was certainly confident that the two witnesses were already risen in the Reformation. The enthusiasts, he said, abused this grand truth 'to popular faction and tumult', and to 'dissentions and schisms', and avoided the 'noble testimony to the Reformation'. ${ }^{117}$ Their misunderstanding of the prophecies resulted in irrational argument. As for the atheists, who believed neither angels nor spirit, More excoriated them as being irrational, in that they rejected the truth which was 'so natural ... and every way unexceptionable to any Rational Man'. ${ }^{118}$ More importantly, he claimed that atheists should not be given liberty of conscience in matters of religion. For him, those who had no religion had not 'any tie of conscience', and were 'mischievous and destructive even to the present Happiness of States and Kingdomes'. ${ }^{119}$ In short, More's supposed rational style of writing was in opposition to the irrationality of the radical dissenters and atheists, and was intended to rid apocalyptic thought of their radicalism.

It is a serious misconception to believe that the apocalyptic mode of thought was monopolised by the radicalism of religious sects. On the contrary, a number of the writings of Anglicans show that they also made use of the apocalypse for their purpose. Unfortunately, however, many historians, such as John Pocock, and Christopher Hill, overlooked the apocalyptic convictions of Anglicanism, even though there have been many studies of millenarianism of the seventeenth century. Hill admitted the possibility of politically significant apocalyptic thought in the years after 1660, but he argued that, after its success as a visible and viable form of social and political discourse between 1640 and 1650, apocalyptic thought vanished at the Restoration because of the official government censorship and control of the press. ${ }^{120}$ However, Hill's argument should be reconsidered. After the Restoration, even after the Glorious Revolution, it is clear that many conformists still interpreted the prophecies of the Bible in this way and that in many contemporary writings the apocalyptic ideas were used as an important part of the rhetorical vindication of social and political systems.

\footnotetext{
116 More, Apocalypsis Apocalypseos; or the Revelation of St John the Divine Unveiled, xxv.

117 More, Paralipomena Prophetica: Containing Several Supplemenss and Defences of Dr H. More, ii-iii.

118 More, Apocalypsis Apocalypseos; or the Revelation of St John the Divine Unveiled, xvi.

119 More, An Explanation of the Grand Mystery of Godliness, 516.

${ }^{120}$ Christopher Hill, Antichrist in Seventeenth-Century England (London: Oxford University Press, 1971), 14850, 157-60.
} 
Like other Anglican clergy, More's apocalyptic rhetoric in his works should be interpreted within its political and religious context. England after the Restoration required political and religious stability, the re-establishment of the Church of England and the return of a monarch who aimed at building up the traditional authority of these two pillars of state. ${ }^{121}$ In this situation, the vindication of the Church of England and of the civil magistrate was at the heart of More's writings. His apocalyptic interpretations were thus understood as contributions to the support of the established system. In his Paralipomena Prophetica, More made it clear that the usefulness of apocalyptic truth was 'for the general Peace of Christendom, for Loyalty to Sovereigns', 'for securing to Monarchs', 'for the preventing barbarous Bloodshed in the Christian World', and 'for the extinguishing Sects and Schisms'. ${ }^{122}$ In this chapter, therefore, I have briefly presented his anti-papal argument, and his support of the authority of the English church and monarch in the Restoration period. It is important to note also that his apocalyptic ideas provided, he was convinced, an explanation based upon reasonableness. This feature, in particular, influenced the latitudinarians in their emphasis on the use of reason in religion.

${ }^{121}$ Gerald R. Cragg, From Puritanism to the Age of Reason: A Study of Changes in Religious Thought within the Church of England, 1660 to 1700 (Cambridge: Cambridge University Press, 1950), 1.

${ }_{122}$ More, Paralipomena Prophetica: Containing Several Supplemenss and Defences of Dr H. More, iii-iv. 


\section{Chapter 2 \\ The Anti-Popery of the Latitudinarians and the Debate over Antichrist}

The English Reformation is easily defined as the antithesis of Roman Catholicism. The religious controversies in which English Protestants were engaged often emerged from their repudiation of the doctrines and rituals of the Church of Rome. One of the central innovations of the Reformation was the rejection of papal authority over the Christian church. While the rejection of papal authority had been sporadically witnessed before the Lutheran Reformation, the Protestant Reformation did not simply deny the pope's authority but also implied a comprehensive attitude towards the whole structure of the Church of Rome. Captured in the term, 'antipopery', this rejection of a cardinal principle of Roman Catholicism was a defining characteristic of the Protestant outlook. Anti-popery was central justification of the English Reformation in the sixteenth century. English Protestant polemicists spent their energy in showing why the Roman Church was idolatrous, superstitious and tyrannical, and they did this in the context of widely shared assumptions about the teleological shape of history and the inevitable apocalypse.

The apocalyptic assumption of early modern Protestantism included a central role for the figure of Antichrist. As Bernard McGinn explains, the teleological understanding of history enabled events to have apocalyptic significance. The confrontation of good and evil, McGinn says, at the end of history, will 'culminate in a series of cataclysmic final events in which Antichrist will nearly destroy the Church before he is annihilated by Christ'. ${ }^{1}$ In the Protestant understanding of history, apocalyptic symbols such as 'antichrist' or 'beast' were used in order to depict the pope and the Church of Rome as a whole. As explained in the previous chapter, political and religious conflicts between Protestantism and Catholicism stimulated leading Protestant authors to identify the pope with Antichrist in the hope of the millennium.

Apocalyptic rhetoric and analysis were widespread among English Protestants, but there were many differences of emphasis, interpretation and nuance

\footnotetext{
${ }^{1}$ Bernard McGinn, 'Angel Pope and Papal Antichrist', Church History 47, no. 2 (2009): 157.
} 
between various thinkers and different denominations or religious traditions. Apocalypticism was a weapon not only for the radical puritans, but also for the Anglicans who endeavoured to harmonise their theology with the magisterial politics of the state Church of England. Many Anglicans were comfortable with an apocalyptic style of biblical exegesis which was different in tone from the expositions of the prophecies used by radicals and sectaries.

English Protestant attitudes towards Catholicism varied in the same way. The identification of Antichrist with the Roman Church had different implications. ${ }^{2}$ The extent to which apocalyptic terms were employed rested upon what individuals thought of Catholicism. The use of apocalyptic language, therefore, was related to the multiple contexts in which individuals took part in political and religious controversies. As Conal Condren shows, linguistic terms were liable to variation of semantics in accordance with changes in the socio-political situation. ${ }^{3}$ The interpretation of apocalyptic terms, in particular, was easily applied to current events so an apocalyptic term had many implications. The different applications of antipopish rhetoric to the religious circumstances show that anti-Catholic language was not fixed but flexible in its use. The definition of a term such as Antichrist changed and developed in connection with political and religious language. As Andrew Starkie says, terms such as 'Antichrist' and 'popery' were 'susceptible to developing complex and competing definitions' due to the 'dynamics of religious and political conflicts' ${ }^{4}$

This chapter undertakes two tasks. First, it examines these Anglican arguments in terms of anti-popery and apocalypticism in the writings of the latitudinarians in the seventeenth century. When looking at religious works by the latitudinarian divines, many historians have detected their anti-Catholicism. They all agree that the latitudinarian clergy were not far different from the mainstream of the Church of England in their criticism of Roman Catholicism and the Church of Rome. It is commonly acknowledged that these Anglicans followed Protestant anti-popish

\footnotetext{
2 Peter Lake, 'William Bradshaw, Antichrist and the Community of the Godly', The Journal of Ecclesiastical History 36, no. 4 (1985): 571.

${ }^{3}$ Conal Condren, The Language of Politics in Seventeenth-Century England (Basingstoke: Macmillan, 1994), 82-3.

4 Andrew Starkie, 'Gilbert Burnet's Reformation and the Semantics of Popery', in Fear, Exclusion and Revolution: Roger Morrice and Britain in the 1680s, ed., Jason McElligott (Aldershot: Ashgate, 2006), 142.
} 
rhetoric by labelling the Roman Church with the characteristics of a false religion. ${ }^{5}$ Many historians also point out that the latitudinarians' anti-popery drew upon arguments that had been deployed by rational and moderate thinkers. They have discovered that the latitudinarian anti-Catholicism was expressed through discourses which were associated with a set of modern ideas. As Peter Lake claims, there was 'an ideal of enlightenment' at the centre of seventeenth-century anti-popish sentiments. ${ }^{6}$

These modern, rational, enlightened ideas took several forms. One was the notion of a modern nation state. Some historians try to place the relationship between the development of national identity and anti-Catholicism in late seventeenth-century and early eighteenth-century England into the broad context of religious changes. ${ }^{7}$ Other historians, however, approach this subject from a different angle. They emphasise that the latitudinarians' use of apocalyptic terms reflects their preoccupation with anti-popery. Tony Claydon and Warren Johnston argue that these moderate conformists believed that Roman Catholicism was antichristian. The apocalyptic beliefs that the world would be terminated in accordance with God's providence as explained in the Scriptures, and that Christ would defeat antichristian religion were embedded in seventeenth-century English Protestantism. ${ }^{8}$ This latitudinarian or moderate perception of the apocalypse and Antichrist could profitably be explored in more depth.

The second task of this chapter is to explore how the latitudinarians understood Roman Catholicism in the context of the religious discourses of Antichrist between the Church of England and Catholicism, and even between the Church of England and Nonconformists. Although the English Protestants in the

\footnotetext{
5 William J. Bulman, Anglican Enlightenment: Orientalism, Religion and Politics in England and Its Empire, 1648-1715 (Cambridge: Cambridge University Press, 2015), 234-35..

${ }^{6}$ Lake, 'Anti-Puritanism: The Structure of a Prejudice', in Religious Politics in Post-Reformation England: Essays in Honour of Nicholas Tyacke, eds., Kenneth Fincham and Peter Lake (Woodbridge: Boydell Press, 2006), 82. For the relationship between anti-popery and rational religion, or rationality, in works by the latitudinarian Anglicans, see Isabel Rivers, Reason, Grace, and Sentiment: A Study of the Language of Religion and Ethics in England, 1660-1780, Vol. 1, Whichcote to Wesley (Cambridge: Cambridge University Press, 1991), chap. 2; Starkie, The Church of England and the Bangorian Controversy: 1716-1721 (Woodbridge: Boydell Press, 2007), 111.

7 Jeremy Black, 'Confessional State or Elect Nation?: Religion and Identity in Eighteenth-Century England', in Protestantism and National Identity: Britain and Ireland, c.1650-c.1850, eds., Tony Claydon and Ian McBride (Cambridge: Cambridge University Press, 1998), 53-74.

8 Tony Claydon, 'Latitudinarianism and Apocalyptic History in the Worldview of Gilbert Burnet, 1643-1715', The Historical Journal 51, no. 3 (2008): 577-97; William III and the Godly Revolution (Cambridge: Cambridge University Press, 1996); Warren Johnston, 'The Anglican Apocalypse in Restoration England', The Journal of Ecclesiastical History 55, no. 3 (2004): 467-501; Revelation Restored: The Apocalypse in Later SeventeenthCentury England (Woodbridge: Boydell Press, 2011).
} 
seventeenth century were deeply influenced by the apocalyptic tradition, the language and terms used in anti-popish arguments had different implications from those of the Reformation era. As Alexandra Walsham points out, anti-popish arguments were often made in the context of an insistence on divine providence. 9 The Protestant emphasis upon providential interference in the protection of the true church turned out to be useful in castigating the Catholic Church for false wonders and deceptive principles. Given that seventeenth-century Englishmen generally assumed that the Roman Church was to be identified with Antichrist and Babylon in the Book of Revelation, it is important to grasp the circumstances behind these arguments. So this chapter will explore the way in which the latitudinarians accommodated and transformed the apocalyptic tradition by their moderate intonation and their concern with arguments based upon rational and historical inferences.

\subsection{Antichrist, Idolatry and Tyranny: The Characteristics of Antichrist}

Anti-popery was deployed in religious debates at various levels by a number of authors. The principles of the Catholic Church provoked constant disputes in both political and religious contexts throughout the early modern period. In seventeenthcentury England the apocalyptic approach to this issue formed a significant genre of anti-Catholic literature. English Protestants discovered that the biblical prophecies described allegorically the whole process of human salvation: fall, redemption, and judgements. ${ }^{10}$ Many commentators had provided apocalyptic interpretations throughout the sixteenth and seventeenth centuries, yet there always was the need to reinterpret and discern prophetic visions.

Protestant apocalyptic writers were heavily concerned with the Catholic threat so it was not surprising that anti-popery was one of the main themes of their works. They made use of apocalyptic terms to make a clear distinction between the godly and the wicked evil. Anti-Catholic polemic played a substantial part in the religious quarrels of the sixteenth century. The reformers found it easy to explain why the papacy was the principal enemy of the Protestant Church in an apocalyptic

\footnotetext{
9 Alexandra Walsham, Providence in Early Modern England (Oxford: Oxford University Press, 1999), 226-32.

10 Alison Shell, Catholicism, Controversy, and the English Literary Imagination, 1558-1660 (Cambridge: Cambridge University Press, 1999), 24-5.
} 
framework. Since Protestants placed the Reformation within the providential narrative, Rome was defined as the most evil agent delivering corruption and idolatry to the world. As the previous chapter shows, apocalyptic terminologies such as 'Antichrist', 'Babylon', 'whore', and 'beasts' were easily employed in works by these reformers. The main theme of apocalyptic worldview was the cosmic battle between Antichrist and the godly.

The continued use of the apocalyptic language to define Rome as the most dangerous enemy can be seen in the anti-Catholic discourse of latitudinarian Anglicans. In the Restoration period, when these conformist clergy started their ministries, anti-Catholic sentiments did not diminish but impacted on the minds of contemporaries. Even though Charles II came to the throne and the Church of England gained support again from the monarch, many Anglicans were still worried about the religious instability caused by political changes. Furthermore, as he began his reign with gestures of religious reconciliation, Charles II seemed to conformists to fail to show himself as holding firm to doctrines and principles of the Church of England. To the English people, the Stuart monarch seemed reluctant to impose the religious measures set out by Parliament in support of the religious domination of the re-established Church of England over nonconformists. On several occasions political disputes stimulated the public's anti-Catholic feelings. Thus, the Declaration of Breda issued by Charles II before he returned to England in 1660, the Declaration of Indulgence in 1672, and James II's Declaration of Indulgence in 1687, these all invigorated anti-Catholic sentiment in that most conformists, and even Nonconformists, had no doubt that these declarations would benefit Catholics. ${ }^{11}$

In addition to their reaction to these agendas for religious liberty, Anglicans had a well-grounded suspicion that their princes privately inclined to support the Catholics. In 1673, the Duke of York, the future king James II, acknowledged his conversion; similarly Charles II was received into the Catholic faith on his deathbed. Many Protestants feared the Stuart monarchs' intention of opening the way for Catholics to be allowed to have a say in politics. Burnet described England in the 1670s as filled with fear about the Catholic threat at home and abroad. 'Now the pulpits', Burnet wrote, 'were full of a new strain: Popery was everywhere preached

${ }^{11}$ Gary S. De Krey, 'Reformation and "Arbitrary Government": London Dissenters and James II's Polity of Toleration, 1687-88', in Fear, Exclusion and Revolution: Roger Morrice and Britain in the 1680s, ed., Jason McElligott (Aldershot: Ashgate, 2006), 13. 
against, and the authority of the laws was much magnified'. ${ }^{12}$ After 1685 James II and his courtiers who were supporters of Catholicism complained that many clergy preached against Catholics. In the meantime, latitudinarian divines published a number of anti-Catholic writings, getting involved in controversy against Catholic priests. They 'began to preach', continued Burnet, 'generally against Popery, which the Dissenters did not. They set themselves to study the points of controversy. And upon that there followed a great variety of small books, that were easily purchased and soon read. They examined all the points of Popery with a solidity of judgment, a clearness of arguing, a depth of learning, and a vivacity of writing, far beyond any thing that had before that time appeared in our language'. ${ }^{13}$

In these circumstances anti-Catholic works such as sermons, treatises, and other forms of materials flourished. Tillotson, Stillingfleet, Tenison, Patrick, and Burnet became prominent anti-Catholic writers from the 1670s onwards. In 1671, Stillingfleet wrote A Discourse Concerning the Idolatry Practised in the Church of Rome, and went on to publish A Defence of the Discourse Concerning the Idolatry in 1676, The Jesuit Loyalty in 1677, and Several Conferences between a Romish Priest, a Fanatick Chaplain, and a Divine of the Church of England in 1679. The trend of anti-popery was also found in Burnet's writings. He wrote an apocalyptic exegesis entitled Mystery of Iniquity Unvailed in a Discourse, wherein is Held Forth the Opposition of the Doctrine, Worship, and Practices of the Roman Church (1673), The Unreasonableness and Impiety of Popery (1678), A Letter Written upon the Discovery of the Late Plot (1678). Patrick's remarkable writings in relation to antipopery were Angliae Speculum: A Glass that Flatters not, Presented to a Country Congregation at the Late Solemn Fast, April 24, 1678, In a Parallel between the Kingdom of Israel and England (1678) and An Answer to a Book, Spread Abroad by the Romish Priests (1692). Tillotson was famous for anti-Catholic sermons designed to criticise the doctrines and principles of the Roman Church.

When Anglican clergy considered anti-Catholicism, they asserted that it was the Church of England that had stood against the idolatry, superstition, and tyranny of the Roman Church and preserved true religion in England. Peter Lake argues that there were two distinct aspects of anti-popery: one is tyranny, the other idolatry. The

12 Gilbert Burnet, Bishop Burnet's History of His Own Time, vol. 1 (London, 1725), 359.
13 Ibid., 3:1148. 
tyranny of popery, according to Lake, consisted most obviously in the pope's usurped claim to be the head of the Church. Through the exercise of that claim he trampled on the rights and liberties not only of other bishops and patriarchs but also on those of Christian princes. However, the tyranny of the pope was not limited to the 'high politics' of Church government. It consisted also of the spiritual oppression inherent in popish religion, whereby the spiritual rights and liberties of ordinary believers were subverted and destroyed. As for idolatry, Lake proceeds to explain, the papacy had embarked on the invention of false forms of worship and beliefs which were of entirely human origin. These false practices and beliefs were a form of idolatry because they had not been ordained by God. The main example of this disposition was the worship of idols and images, the use of saints as intercessors, the virtual deification of the Virgin Mary, and last but not least, the doctrine of transubstantiation. ${ }^{14}$ Thus the Roman Catholic tendency towards tyranny and idolatry helped the Protestant church in presenting itself as defending the people against oppression and the risk of idolatry. Antipopery thus became a defining mark of English Protestantism.

One of eminent exponents of later seventeenth-century Anglican anti-popery was Henry More who became well-known for his criticism of Catholicism from an apocalyptic perspective. More was the leading and most sophisticated exegete of Prophecies and the Revelation. He set out his apocalyptic understanding in his major works such as A Modest Enquiry into the Mystery of Iniquity (1664), Synopsis Prophetica (1664), Apocalypsis Apocalypseos (1680), and A plain and continued exposition of the several prophecies or divine visions of the prophet Daniel (1681). The great length of these works, devoted to the exposition of the apocalypse, demonstrate how much time he spent studying God's providence as expressed in the Scriptures.

It is obvious that More's apocalyptic thought in turn owed much to the earlier theologian Joseph Mede (1586-1639) who made very significant contribution to the apocalyptic interpretation of the Scriptures. More admits that 'he that I am most of all beholden to, is that incomparably Pious and Learned person Mr. Joseph Mede'. ${ }^{15}$ Although Mede's understanding of apocalypse, More confesses, differed from his

\footnotetext{
${ }^{14}$ Lake, 'Anti-Popery: The Structure of a Prejudice', in Conflict in Early Stuart England: Studies in Religion and Politics 1603-1642, eds., Richard Cust and Ann Hughes (London: Longman, 1989), 74-6.

${ }^{15}$ Henry More, Apocalypsis Apocalypseos; or the Revelation of St John the Divine Unveiled (London, 1680), 249.
} 
own at some points, he does not hesitate to recognise that Mede had a correct view of the visions of the prophecies. ${ }^{16}$ More's interpretation of apocalypse was broadly in line with that of Mede, Hammond and Brightman and opposed to the views of Hugo Grotius and Richard Baxter.

Following those eminent expositors' interpretations, More's apocalyptic writings are largely centred on detailed expositions of the visions and imageries of prophecies. He takes for granted that many of them represent the evil aspects of Catholicism. It is striking that his interpretation of the end of the world drawn from God's revelation is inextricably linked to anti-popery. He offers his exposition of the Books of Daniel and Revelation as being 'full satisfaction in the great Controversy betwixt us and the Papists, who leave no stone unmoved to pervert Souls, and to bring them over to their Idolatrous Church'. ${ }^{17}$ More understands that 'the pope was that Man of sin or Antichrist, and their Church idolatrous by reason of their adoration of the Host, invocation of the Saints and worshipping of Images'. ${ }^{18}$

More identified the Roman church with Antichrist, labelling the pope with the images of 'beast', 'the Whore of Babylon', and 'dragon', and so forth. ${ }^{19}$ It is selfevident why the Roman church was dubbed with these pejorative titles. According to More, 'the likeness of similitude that the state of the Roman Church bears to ancient Paganism in Idolatry, Superstition and Cruelty is so complete ... that I cannot but devoutly admire the exact veracity of these Divine Visions in so material a Prediction'. ${ }^{20}$ He tries to make it clear that these various images referred not to the Roman paganism into which the Roman Empire sank, but to the Roman church, by claiming that 'the Whore of Babylon cannot be understood of Rome Pagan, but of Rome pagano-Christian, or of the Roman Hierarchy ... corrupting Christianity with the illicite Doctrines and practices of Idolatry'. ${ }^{21}$ For More, the problem of Catholicism was that it confused spiritual and political powers: this was evident in the complex characteristics of Antichrist.

More explained the nature of 'Antichrist' in detail. The power of the dragon and the two horned beast, described in the Book of Revelation, was divided into two:

\footnotetext{
${ }_{16}^{16}$ More, A Plain and Continued Expeosition of the Several Prophecies (London, 1681), xvi-xvii.

${ }_{17}^{17}$ Ibid., 267; Johnston, 'The Anglican Apocalypse in Restoration England', 478.

${ }_{18}$ More, A Plain and Continued Expeosition of the Several Prophecies, lii.

${ }_{19}$ See More, Synopsis Prophetica; or, the Second Part of the Enquiry into the Mystery of Iniquity (London, 1664), chaps. 4 and 11; Apocalypsis Apocalypseos; or the Revelation of St John the Divine Unveiled, chap. 12.

${ }^{20}$ More, Synopsis Prophetica; or, the Second Part of the Enquiry into the Mystery of Iniquity, 335.

${ }^{21}$ Ibid., 274.
} 
political and ministerial powers. More went on to explain that antichristianism consisted of two things: Firstly, he wrote, 'In the instituting of such Laws, or authoritatively teaching such Doctrines, and promoting or commanding such practices, as naturally defeat and frustrate the true scope and purpose of the Gospel of Christ'. And secondly, 'in the doing this with such artifice and so fair pretences, that they bear the world in hand in the mean time that they are doing the work of God, and promoting the Interest of the Kingdom of his Son Jesus'. ${ }^{22}$

More thought that Antichrist was, at first, idolatrous in that the 'Sacerdotal Hierarchy' imposed a false way of worshipping other things which are not God, whether visible or not. As examples, he enumerated the idolatrous practices of worship, including 'the Religious worship of the Cross, as also the Image of God the Father, Son, or Holy Ghost; the devotional invocation of the blessed Virgin, or any other Saints, or Angels; the worshipping of their Pictures, or Images ... and lastly, the adoration of the consecrated Bread in the Eucharist upon the imagination that it transubstantiated into the very body of Christ'. ${ }^{23}$ Thus he understood idolatry not just as idol worship, but also as any practices or doctrines that encourage the worship of anything that is not the real God.

Another main characteristic of Antichrist was tyranny. Antichrist, said More, made 'himself so absolute a Head of the Church', and cut off Jesus from being the Head of the Church. Then, in doing so, he placed 'himself to be the notorious Antichrist in Christendom', while pretending to be eager to do the work of God. ${ }^{24}$ Antichrist was, furthermore, he stated, 'more oblique and more subtil'. Therefore, 'it is no wonder that their Antichrist [is]... not a gross and violent Invader of the Empire of Christ, but a more cunning Impostour and insinuating Hypocrite' ${ }^{25}$ It seems that the pope's pretence of imperial power by holding on to political power so as to take control over civil princes or even laymen was unarguably tyranny in More's viewpoint. The head of Roman hierarchy was, More criticised, 'so Emperour-like and of such a Senatorious splendour, that it is manifest that there is an affectation of Imperial power in the Pope himself; his Crown and Vestments being so plainly Imperial'. He was severely critical of the papacy, which when laying claim to

\footnotetext{
${ }^{22}$ More, A Modesty Enquiry into the Mystery of Iniquity (London, 1664), 2.

${ }^{23}$ Ibid., 11-3.

${ }_{24}$ More, Synopsis Prophetica; or, the Second Part of the Enquiry into the Mystery of Iniquity, 208.

25 Ibid., 209.
} 
supremacy and spiritual authority over the church and state, had forced civil magistrates to persecute dissenting people. All this was, he concluded, no more than the imitation of imperial power and dignity. ${ }^{26}$

More was the dominant influence on the succeeding generation of Anglican polemicists. Following More's emphasis on Catholic idolatry and tyranny, Anglican clergy like Gilbert Burnet, Edward Stillingfleet, and John Tillotson published many works denouncing Catholic doctrines and practices. As Martin Grieg has argued, Burnet's work Mystery of Iniquity Unveiled (1673) was very nearly the same as More's Modest Inquiry into the Mystery of Iniquity (1664). Burnet's arguments and interpretative framework were entirely an imitation of More's apocalyptic interpretation. In later life Burnet 'openly acknowledged the debt that he owed to the Cambridge Platonists and their followers'. ${ }^{27}$ In his Mystery of Iniquity Unveiled which attempted to explicate the mystery of God's revelation and the prophecies, Burnet argued that the Scriptures warned the people of a 'mystery of iniquity', namely, the emergence of Antichrist, who had bewitched the world under the mask of true Christianity. According to Burnet, it was obvious that antichristianism was closely linked to the idolatry and tyranny of the Catholic Church and involved persecution, hatred, and impatience. ${ }^{28}$ For Burnet idolatry could be seen either in the worshipping of God in a false way or in the offering of divine adoration to those who were no gods. ${ }^{29}$

Burnet's survey of Christian history reinforced his view of Catholicism as antichristian. He drew attention to the similarity between Catholic and pagan practices. It was evident to Burnet that the worship in the Church of Rome was idolatry because the Church borrowed its external forms of worship from 'Heathens'. He thought that worshipping God in 'a false manner' came from 'both Jews and Gentiles of Idolatry'. Burnet presented the Old Testament as a repository of stories that demonstrated how, since Aaron's false worship, the Jews corrupted the first two divine commandments by worshipping God in their own idolatrous ways and how many times this idolatry was condemned as 'whoredom'. ${ }^{30}$ As for the influence of

\footnotetext{
${ }^{26}$ Ibid., 280.

27 Martin Greig, 'Gilbert Burnet (1643-1715)', in Oxford Dictionary of National Biography (2004).

28 Burnet, A Relation of the Death of the Primitive Persecuters (Amsterdam, 1687), 11.

${ }^{29}$ More, The Mystery of Iniquity Unveiled in a Discourse, Wherein Is Held Forth the Opposition of the Doctrine, Worship, and Practices of the Roman Church (London, 1673), 15-6.

${ }^{30}$ Ibid., 16, 18-20.
} 
pagan practices on Christianity, Burnet called for an examination of church history from which it was clear that various popes and General Councils had erred in religious matters, and had been anathematized as heretics. He enumerated Catholic practices which posed, for him, a remarkable contrast to the values taught to the world by the blood of Christ. For Burnet Catholic inventions that distracted the laity from 'the spirit of Christianity' were plausible enough evidences to show that Catholicism was a corrupted institution. ${ }^{31}$ In disputing the Catholic tradition, Burnet thought that the doctrines taught by the Roman Church were not those received in their purity from the primitive church. For example, he argued that the Fathers magnified the Sacrament but in doing so, did not believe in the 'corporal presence', unlike the Roman Church of his time which believed firmly in transubstantiation. In his eyes there must had been a distortion in the nature of Christianity 'through the ignorance of some ages' at a time when there little historical records written remained. $^{32}$

Burnet thought religious persecution was based upon two pillars of Catholicism: one was the authority of the church, the other was the certainty of tradition. In his letter, Burnet argued that the Roman church had claimed the power of deposing kings on the basis of these two elements, so that the pope could persecute and execute other men who opposed him. ${ }^{33}$ For Burnet, however, these two fundamental ideas were irrational. They could not be rationally defended because the deposing doctrines were not a tradition of the Christian Church, and because the church of the latter ages did not follow the same doctrine as the primitive church of the first centuries. ${ }^{34}$ So he could conclude that the Church of Rome was an irrational and cruel enemy, and that persecution was antichristian. ${ }^{35}$

Burnet condemned that Rome supported tyrannical persecution of Protestants, and that the Catholic doctrine of infallibility prevented the people from using reason to examine the articles of faith of the Church. ${ }^{36}$ Although he admitted that there was an authority that belonged to the civil and ecclesiastical power in order to impose

\footnotetext{
31 Ibid., 49-58.

32 Ibid., 120-21.

${ }^{33}$ Burnet, A Letter Written Upon the Discovery of the Late Plot (London, 1678), 3.

${ }^{34}$ Ibid., 41.

${ }^{35}$ Burnet, A Sermon Preached at the Chappel of the Rolls, on the Fifth of November, 1684. Being Gun-PowderTreason-Day (London, 1684), 1; The Mystery of Iniquity Unveiled in a Discourse, Wherein Is Held Forth the Opposition of the Doctrine, Worship, and Practices of the Roman Church, 142.

${ }^{36}$ Burnet, A Sermon Preached at the Chappel of the Rolls, on the Fifth of November, 1684. Being Gun-PowderTreason-Day, 1-2.
} 
things indifferent, he stipulated that the Roman church had become tyrannical because, with its superstitious practices, it desired to restrain human conscience, which should be subordinate to Christ alone. In addition to this spiritual aspect, the Church of Rome was thought to be guilty of political abuse by its claim of an authority to excommunicate civil magistrates. Burnet worried that, 'by consequence, private persons may conspire to take away the life of a King so deposed' ${ }^{37}$ For him the irrationality and corruptions of Roman Catholicism gave prominence to the characteristics of the Reformed church whose doctrines followed those of the primitive church: simplicity, perspicuity, reasonableness, easiness, gentleness and so forth. ${ }^{38}$ Burnet's view of the struggle between a true and a false church needs to be understood in this context. The reason why the Church of Rome was Antichrist was because she had abandoned the features of the primitive church.

Other Anglican polemicists pursued similar arguments against the Roman Church but with slightly different emphases. This difference of emphasis might be due to temperamental and stylistic preferences, or it might arise from the terms of the pamphlet wars in which the polemicists were engaged. Edward Stillingfleet provides a clear contrast to those Anglican writers considered earlier. Apocalyptic terms were not as explicit in Stillingfleet's writings as in those of other latitudinarian colleagues like More and Burnet. Stillingfleet did not attempt to engage himself with an apocalyptic understanding of Catholicism, whereas, as discussed earlier, the detailed description of the mystery of the apocalypse was the approach of the Anglican mainstream. However, that is not to say that apocalyptic conviction was not included in his theology. His interpretation of God's providence was also of importance in his vindication of Christianity, and his anti-popery was rooted in an apocalyptic view of Catholicism. Much of Stillingfleet's anti-Catholic polemic was produced as part of a long-running debate with the Roman Catholic controversialist Thomas Godden (1623-1688), who had been converted to Catholicism by John Sergeant (1623-1707) and had become a famous Catholic preacher. ${ }^{39}$

\footnotetext{
37 Burnet, A Letter Written Upon the Discovery of the Late Plot, 8.

${ }^{38}$ Burnet, The Unreasonableness and Impiety of Popery (London, 1678), 22; The Mystery of Iniquity Unveiled in a Discourse, Wherein Is Held Forth the Opposition of the Doctrine, Worship, and Practices of the Roman Church, 131-35.

39 Robert Todd Carroll, The Common-Sense Philosophy of Religion of Bishop Edward Stillingfleet, 1635-1699 (The Hague: Nijhoff, 1975), 51.
} 
Godden was affronted by the Anglican accusation of idolatry. In response to Stillingfleet's Discourse concerning the Idolatry (1671), Godden wrote of 'The Charge of Idolatry, which he most unjustly fixes upon the Church of Rome'. ${ }^{40}$ As much as Stillingfleet attempted to demonstrate the falseness of Catholic practices by using plain and rational argumentations, his Catholic opponents kept bringing the issue back to apocalyptic thought. Godden maintained that if the dispute between him and Stillingfleet was based upon the understanding of the Church of Rome as being guilty of heresy or of idolatry, as the Protestants claimed, then

it falls under the Apostles Excommunication and so remains depriv'd of the lawful Authority to use and exercise the Power of Orders; and consequently the Authority of Governing, Preaching, and Administring Sacraments, which those of the Church of England challenge to themselves, as deriv'd from the Church of Rome, can be no true and lawful Jurisdiction, but usurped and Antichristian. $^{41}$

In other words, if the Roman Church was antichristian then so too was the Church of England because it derived its powers from the Church of Rome.

Although he made little effort to identify Catholicism with a number of apocalyptic images, Stillingfleet devoted many pages of A Discourse Concerning the Idolatry Practised in the Church of Rome (1671) to showing why practices used in the Church of Rome were idolatrous and thus Catholicism was antichristian. He gave particular attention to the idolatry and fanaticism - or enthusiasm - of the Roman Church. This work was intended as a repudiation of the false doctrines and practices of Catholicism such as the worshipping of images, the invocation of saints, and the compensation for sins by indulgence, and a justification of the authority of the Reformation against it.

At the beginning of his Discourse Concerning the Idolatry, Stillingfleet did not hide his fear of Catholic 'idolatry'. He tried to show that the Reformed Church had stood in opposition to the idolatry and superstition of the Roman Church by using many quotations involving charges of idolatry against the Church of Rome from Anglican bishops like Jewell, Whitgift, Bilson, Usher and others. Following previous Anglicans, he placed himself in the long tradition of controversy between

\footnotetext{
40 Thomas Godden, Catholicks No Idolaters: Or a Full Refutation of Dr. Stillingfleet's Unjust Charge of Idolatry against the Church of Rome (London, 1672), sig. a2r.

${ }^{41}$ Ibid., sig. b4r.
} 
Anglicans and Catholics. According to Stillingfleet, ancient Christianity was not tainted with idolatry.

In his works on anti-popery Stillingfleet also focused on the danger of fanaticism associated with the Roman church. By fanaticism he understood either an enthusiastic way in which religion was dealt with, or resisting authority under the pretense of religion. He worried that 'there have not been greater Enthusiasts among us in England, than have been in the Roman Church'. ${ }^{42}$ Especially, he pointed out the threat to the Reformed church from the religious orders of the Roman church. He took it as proven that orders such as the Jesuits, Benedictines, Franciscans and others encouraged and promoted enthusiasm among the people to reduce them to superstition and to make them follow a mystical and unintelligible way of devotion. ${ }^{43}$ Furthermore, in a sermon preached at St. Margaret's Westminster in 1673, he warned, that their false teaching and its results could greatly endanger civil society. ${ }^{44}$

Stillinfleet's Discourse Concerning the Idolatry was just the initial volley in a long-running controversy with Roman apologists. For the next two decades, Sergeant, Cressy, and Godden were engaged in an exchange of views with Stillingfleet. It seems that Stillingfleet found Godden an improvement on other Catholic writers whereas he described Sergeant as a rat gnawing at the leaves while the body of argument was left untouched. ${ }^{45}$ After the publication of Stillingfleet's Discourse Concerning the Idolatry, Godden wrote several works to repudiate his criticism of the Catholic Church: Catholick No Idolaters (1672), A Just Discharge of Doctor Stillingfleet's Unjust Charge of Idolatry (1677), Sermon at Somerset-house in June 29 (1686) and so on. Godden thought that Stillingfleet accused Catholicism of idolatry unjustly because he wanted to justify the separation of the Church of England from the Roman Church. Henceforth, their separation 'can be no Schism either before God or Man'. ${ }^{46}$ Godden answered Stillingfleet's charge of idolatry with respect to the Catholic worship of images by claiming that it was permissible to worship God by sacred images such as 'Crucifixes'. Godden admitted that 'we give indeed a veneration to Images', but argued that 'the Image of God is not another God

\footnotetext{
42 Edward Stillingfleet, A Discourse Concerning the Idolatry Practised in the Church of Rome (London, 1671), 209.

${ }^{43}$ Ibid., 3 .

44 Stillingfleet, 'Sermon XIV Preached Novemb. 5. 1673. At St. Margarett's Westminster before the Honourable House of Commons', in Fifty Sermons Preached Upon Several Occasions (London, 1707), 209.

${ }^{45}$ Stillingfleet, A Discourse Concerning the Idolatry Practised in the Church of Rome, sig. b1v.

${ }^{46}$ Godden, A Just Discharge of Doctor Stillingfleet's Unjust Charge of Idolatry (Paris, 1677), sig. a2v.
} 
besides him, nor is the Worship of it the Worship of another God, but of him who is represented by it'. ${ }^{47}$ Stillingfleet's theological and historical attack on Catholicism had a powerful impact on English Catholic polemicists up until the eighteenth century. A few decades after Stillingfleet's death, Charles Dodd gave a detailed explanation of the origin of the debate between these two divines. In his three volumes of the Church History of England from the Year 1500 to the Year 1688, Dodd, a Catholic historian, began his discussion by asking whether a Protestant could be saved if he became a Papist. ${ }^{48}$

Stillingfleet responded to Godden's defence of Catholicism by publishing An Answer to Several Late Treatises, Occasioned by a Book Entitled A Discourse Concerning the Idolatry (1673), A Defence of the Discourse of the Idolatry (1676), and Several Conferences between a Romish Priest, and a Fanatick Chaplain, and a Divine of the Church of England (1679). Although many other works against the Catholic polemicists had been published, Stillingfleet's anti-Catholic arguments remained the same. ${ }^{49}$ Not only did Stillingfleet express anti-popery in the style of demonstration with historical and biblical analysis of details of the matter at issue. Among his works on anti-popery Several Conferences between a Romish Priest ... a Divine of the Church of England took the form of dialogue between two fictional characters, one was a Catholic priest and the other an Anglican clergyman. Stillingfleet, like other contemporaries, used various genres of writings to make it easy for his arguments to be propagated to the readers.

\subsection{The Political Context of Anti-Catholicism}

The latitudinarians' anti-Catholicism became heated as they saw Restoration politics being shaken by the Catholic threat. Renewed attention was given to the history of the political and religious corruptions of the papacy on several occasions. From the mid-1670s, events in England seemed to English conformists to weaken the ascendancy of the Church of England. After 1678 the Popish Plot, a supposed Catholic-led plot to assassinate the king and introduce Catholicism to the royal court,

\footnotetext{
47 Ibid., 16-7.

48 Charles Dodd, The Church History of England from the Year 1500 to the Year 1688, vol. 3 (London, 1742), 470.

${ }^{49}$ For religious debates between Stillingfleet and Cressy, Godden, Dryden and others, see Carroll, The CommonSense Philosophy of Religion of Bishop Edward Stillingfleet, 1635-1699, 42-57.
} 
the Exclusion Crisis, and the accession of James II, who issued a Declaration of Indulgence on 4 April 1687, all provoked and amplified anti-popery sentiment among Englishmen. The 1687 Declaration of Indulgence suspended penal laws and granted freedom of religion in England. These events increased the complexity of anti-Catholic argument.

Whig sympathizers viewed the cavaliers and high episcopal priests as related to popery. The Earl of Shaftesbury, Anthony Ashley Cooper (1621-1683), the prominent leader of the Whig party during the Exclusion Crisis, thought that the Earl of Danby, Thomas Osborne (1632-1712), suspected of supporting arbitrary government and jure divino episcopacy, was thought to be in league with the Duke of York, the heir to the throne. Throughout the latter half of the 1670s Shaftesbury opposed Catholic sympathisers to secure England from the threat of popery and arbitrary government. In his Letter from a Person of the Quality to His Friend in the Country (1675), Shaftesbury claimed that the 'High Episcopal Man, and the Old Cavalier, who are to swallow the hopes of enjoying all the Power and Office of the Kingdom' tried to make 'the Government absolute and Arbitrary, and allow Monarchy as well as Episcopacy to be Jure Divino' which was not limited by human laws. ${ }^{50}$ In this context, Shaftesbury's view of anti-popery was, as Spurr argues, 'a refusal to accept the role of salve and papist, and a determination to resist the growth of popery and arbitrary government', ${ }^{51}$ In his argument, any political project which could result in the emancipation of Catholicism was an implied threat to Protestantism as protected by the Parliament. Andrew Marvell, a Nonconformist, connected popery to absolutism. In the first page of a tract written in 1677, he claimed that 'there has now for diverse Years, a design been carried on, to change the Lawfull Government of England into an Absolute Tyranny, and to convert the established Protestant Religion into down-right Popery'. ${ }^{52}$ Shaftsbury and Marvell's anti-popery was defined in terms of the fear of the arbitrary government.

The response of Nonconformists to the religious policies of the Catholic prince was not monolithic. When James II attempted to introduce a toleration of

\footnotetext{
50 [Anthony Ashley Cooper], A Letter from a Person of the Quality to His Friend in the Country (London, 1675), 1.

51 John Spurr, 'Shaftesbury and the Politics of Religion', in Anthony Ashley Cooper, First Earl of Shaftesbury, 1621-1683, ed., John Spurr (Farnham: Ashgate, 2011), 143-44.

52 [Andrew Marvell], An Account of the Growth of Popery, and Arbitrary Government in England (Amsterdam, 1677), 1.
} 
religious sects including Catholics, the London Dissenters praised him even though the policy was also aimed at Catholics. They were willing to embrace James' declaration. Being opposed to penal laws, nonconformist divines argued for the royal dispensation and went so far as to claim that penal laws should be abrogated because they were irrational and against divine law. Some Dissenters like Shute and Popple defended liberty of conscience, and argued that it should granted to Catholics. They believed that the potential danger from Catholicism could be restrained by an appropriate parliamentary act guaranteeing liberty of conscience. ${ }^{53}$

The various responses of dissenting sympathisers to the King's scheme for religious toleration contrasted sharply with that of Anglican divines who worried the emancipation of Catholics from all legal conditions laid down by a series of penal laws. A decade-long conflict in politics had inflamed this fear of popery. The revelation of the Popish Plot led to efforts in successive parliaments from 15 May 1679 until 1681 to introduce several bills to exclude James, a suspicious Catholic, from the succession to the throne. Two consecutive sessions of the parliament in March 1679, October 1680, and in March 1681 attempted to employ legal actions to prevent the Duke of York from ascending to the throne.

In addition to the political tension in the English Parliament, the activity of Catholic Church and princes in neighbouring countries were another cause for antipopery. With the revocation of the Edict of Nantes in 1685, Louis XIV took away the privileges that Huguenots in France enjoyed. One of the coercive methods used by Louis XIV to force the French Protestants to convert to Catholicism was the dragonnades: the lodging of dragoons or infantrymen in the homes of Huguenots in order to put aggressive pressure upon them to either convert or to seek asylum in neighbouring countries. This anti-Protestant policy reminded English Protestants of earlier precedents of Catholic persecution in Europe. Anti-Catholicism was further increased by the translation of some French works into English. These described the persecution of the Protestants and strengthened the fear of Catholicism spreading across England. For example, Pierre Jurieu's Monsieur Jurieu's Pastoral Letters, Directed to the Protestants in France, who Groan under the Babylonish Captivity, translated in 1688, and A Full Account of the Barbarous and Unhumane Usages of ${ }^{53}$ De Krey, 'Reformation and “Arbitrary Government”: London Dissenters and James II's Polity of Toleration,
1687-88', 15, 20, 26-7. 
the French Protestants in France written by an anonymous author in 1685, depicted how severely the French Protestants were suffering from violence and persecution under the Catholic prince. These two works demonstrated how the king's arbitrary command deprived French Huguenots of religious liberty. Not only French Protestants 'were oblig'd to take upon themselves the Title of Roman Catholic contrary to their will', but the whole of France 'was stricken with terror, batherd[bathed] in tears, and red with blood; Paris and Brie saw nothing round about, but sanguinary Troops, and Emissaries laden with the Spoils of the Reformed, and covered with their blood'. 54

A series of events at home and abroad shaped the context for the apocalyptic interpretation of Catholicism during the 1670s and 80s. The suspicion that Stuart monarchs sympathised with Catholics made conformists focus upon the political power that Catholicism was able to make use. In parallel with considerations of idolatry and superstition in the form of worship, the tyranny of Catholicism gradually became a matter of concern for anti-Catholic polemicists. In this context antiCatholic rhetoric was combined with a repudiation of an 'arbitrary' government. Some of latitudinarian clergy also reaffirmed anti-popery in their concern over the growth of the tyrannical power of the Catholic Church. They thought that the arbitrary use of monarchical power would be associated with magisterial ambition in pursuing policy in favour of the tyrannical Catholic Church. Monarchical attempts to enforce the Declaration of Indulgence during the Restoration provoked Burnet's antipopish sentiment. In his History of His Own Time, Burnet wrote that 'the House of Commons was upon this all in a flame' because 'they saw popery and slavery lay at the bottom' of the Declaration. According to Burnet, Parliament thought that 'the King had a power of pardoning, yet he had not a power to authorize men to break laws' ${ }^{55}$ When Henry More composed his exposition of the prophecies of Daniel in 1681, he was reacting to contemporary dangers: 'there being that strong Effort by the Popish Party to bring their Religion again here into England' ${ }^{56}$ Tillotson also expressed concern that both 'the Jansenists and the Jesuits' were 'subject to Antichrist their common head', so that they had a common interest in driving

\footnotetext{
54 Anonymous, A Full Account of the Barbarous and Unhumane Usages of the French Protestants in France (n.p., 1685), 2; Pierre Jurieu, Monsieur Jurieu's Pastoral Letters, Directed to the Protestants in France, Who Groan under the Babylonish Captivity (London, 1688), 13.

${ }_{55}$ Burnet, Bishop Burnet's History of His Own Time, 1:346.

56 More, A Plain and Continued Expeosition of the Several Prophecies, lxxx.
} 
forward the 'extirpation of Protestants' 57 The antipathy of these two men to popery was based on their conviction that popery inevitably involved tyranny and persecution of English Protestants. ${ }^{58}$

The prominent latitudinarian divines thought that James's religious policy would allow a tyrannical authority of the Catholic Church to dominate English politics. They again produced prophetical expositions to justify their claims that the new magistrate should protect England from popery. For them the biblical prophecies must be read in terms of the defeat of tyrannical Catholicism by the divine Protestant magistrate. In January 1689, after James's exile from England, Patrick, the dean of Peterborough, preached a sermon in front of William III. In this sermon, Patrick welcomed recent events by claiming that:

the wonderful Work which God hath wrought in our days, and before our Eyes, by that great Prince, whose Spirit he hath stirred up to undertake our Deliverance from Popish Tyranny, and whose Proceedings he hath blessed with amazing Success, may well awaken the minds of considering Persons to expect greater things he is about to do in the World, which groaneth (as the Apostle says the whole Creation did in their days) to be delivered into the glorious Liberty of the Children of God. ${ }^{59}$

Patrick shared this approach to anti-Catholicism based upon apocalyptic exegesis. For him, the tyrannical inclination of popery to impose power over the people was a representation of Antichrist. As Patrick confidently claimed in his book written after William's accession to the throne, An Answer to a Book, Spread Abroad by the Romish Priests (1692), 'Babylon', the 'beast', and the 'Great Whore' described in the chapter 17 and 18 of the Book of Revelation, assuredly represented the Roman Church. ${ }^{60}$ Like More, Burnet, and Stillingfleet, Patrick emphasised the danger of the tyranny of the Church of Rome. He thought that the Church of Rome broke the bond of peace in which the Christian community was preserved. 'They have broken', he

\footnotetext{
57 John Tillotson, 'Sermon CXXIX: The Children of This World Wiser Than the Children of Light', in Sermons on Several Subjects and Occasions, by the Most Reverend Dr. John Tillotson, Late Archbishop of Canterbury (London, 1757), 424.

${ }^{58}$ Some scholars see the anti-popery of the latitudinarians in terms of legality or antipathy to jure divino episcopacy. Mark Goldie, 'Toleration and the Godly Prince in Restoration England', in Liberty, Authority, Formality: Political Ideas and Culture, 1600-1900, eds., John Morrow and Jonathan Scott (Exeter: Imprint Academic, 2008), 45-65; Starkie, 'Gilbert Burnet's Reformation and the Semantics of Popery', 138-53.

59 Simon Patrick, A Sermon Preached in the Chappel of St. James's before His Highness the Prince of Orange, the 20th of January, 1688 (London, 1689), 32.

${ }^{60}$ Patrick, An Answer to a Book, Spread Abroad by the Romish Priests, Intituled, the Touchstone of the Reformed Gospel Wherein the True Doctrine of the Church of England and Many Texts of the Holy Scripture Are Faithfully Explained (London, 1692), 88-9.
} 
argued, 'all Communion, by their Tyrannical impositions, and making other rules besides the Evangelical Doctrine'. ${ }^{61}$ It was natural for him to derive evidences from the Scriptures: the Scriptures, Patrick thought, taught the people not to keep or worship any image in the place of the real God. Thus, it was a clear consequence that 'God's picture or image must not be made'. These idolatrous things, including the doctrines of purgatory and indulgences, were imposed on the people in a tyrannical way. ${ }^{62}$

Patrick argued that the tradition from which the Catholics derived their infallible doctrines or interpretations did not actually underpin their faith but, on the contrary, undermined it. He conceded that the authority of the Church could be derived from primitive tradition because the Scripture was not sufficient and of itself for all matters in religion to be determined. He gave, however, his assent to the arguments of the primitive Fathers such as Vincentius and Tertullian that 'the Divine Scripture is the first place as our guide', and that 'the creeds or rule of faith are all contained in the Scriptures and need the help of no tradition' ${ }^{63}$ For him the primitive and ancient tradition of Catholicism was rather a distortion. In short, "the Roman Church pretended to traditions, where there are none, in several cases perverted them, and then, turned them into other things'. 64

\subsection{The Debate over the Identity of Antichrist in the Restoration}

As this dissertation emphasises, anti-popery was a powerful sentiment which dominated religious controversies in seventeenth-century England. It was widely shared by those within the Church of England and across the various denominations of Protestant Nonconformity. Generally speaking, the anti-popish polemic of conformists had a similar rhetorical approach to that of Nonconformists. The condemnation of the Catholic Church as a tool for submitting the church to superstition, idolatry, and tyranny was commonplace in the Protestant anti-Catholic argument. Protestants were united in the rejection of the principal Catholic doctrines and in the criticism of the brutality of persecution carried out by Catholic priests. They all agreed that the Reformation was justifiable in that it was now impossible to

\footnotetext{
${ }^{61}$ Ibid., 4.

${ }^{62}$ Ibid., 248-49.

${ }^{63}$ Ibid., 10-5.

${ }^{64}$ Ibid., 27.
} 
reform and revive a pure Christian spirit within the Roman Church. The first step for promoting Protestantism was to reject the fundamentals on which the papacy was grounded. This was the common argument in the application of anti-popery to the apocalyptic framework.

As I have shown, the apocalyptic rhetoric shaped the anti-Catholic tone set by latitudinarian clergy and theologians like More, Stillingfleet, Burnet, and Patrick. Their anti-Catholicism was not just rhetoric, but also a conviction. With respect to the apocalyptic prophecy of the fate of Antichrist these moderate Anglicans were convinced of God's unchanging providence which foretold of the new heaven to come for His subjects at the end of this world. Many Anglicans thus shared an apocalyptic belief that the biblical prophecies forespoke that the coming of Christ would follow the defeat of Antichrist, as he struggled to seduce God's people in the course of human history. The identity of Antichrist was, as we have seen, a key feature of protestant anti-popery.

This was a subject of debate in late seventeenth-century England. To understand the latitudinarians' use of the term Antichrist requires the examination of the competing Protestant arguments of the period. Although the majority of English Protestants in the late seventeenth century espoused the apocalyptic interpretive tradition, yet not all Englishmen agreed on the identification of Antichrist with the Church of Rome. Nonconformists and Anglicans varied in their explanations of the apocalyptic texts. Earlier in the century, some puritans made use of an apocalyptic exegesis in arguing against the Church of England. Thomas Wilson employed Brightman's view of the Church of England and claimed that the Church was Laodicea, signifying religious lukewarmness. As Paul Christianson shows, Wilson demanded that retribution against this Babylon - 'whether papists or Arminians' was indispensable for the reformation of the church. ${ }^{65}$ The scholarly consensus is that early seventeenth-century English Protestants were, by and large, convinced that the pope was Antichrist and this belief reinforced their anti-Catholicism, but this agreement was shattered when political conflicts triggered religious quarrels in the 1630s. ${ }^{66}$ As religious conflicts intensified from that decade, the use of the term

\footnotetext{
${ }^{65}$ Paul Christianson, 'From Expectation to Militance: Reformers and Babylon in the First Two Years of the Long Parliament', The Journal of Ecclesiastical History 24, no. 3 (1973): 229.

${ }^{66}$ John Coffey, ed., Persecution and Toleration in Protestant England, 1558-1689 (Harlow: Longman, 2000), 30.
} 
Antichrist was made for different purposes, and the interpretation of this apocalyptic epithet had different implications.

The 1630s saw the apocalyptic interpretation of Nonconformists demanding the expulsion of Laudianism and its supporters, and expressing suspicion that the Church of England was linked to the Roman Church. ${ }^{67}$ During the 1640 s, puritans viewed the monarch and the Anglican clergy who were the proponents of Laudianism, as agents of popery or Antichrist. ${ }^{68}$ The comparison of the Church of England with Rome facilitated the criticism of practices in the Church of England. One of the prominent Anglicans who disagreed with mainstream Protestantism on the apocalyptic tradition was Henry Hammond. Hammond claimed that the most dangerous threat was not the papacy but the Turks, whom he identified with Gog and Magog. ${ }^{69}$

After the restoration of the episcopal Church of England and the 1662 Act of Uniformity, Nonconformists readily resorted to this pattern of denouncing the national church as Antichrist. The Church of England was viewed by Nonconformists as Antichrist because they saw the Anglican clergy as supporting the penal laws of the 1660s. Although the extent to which dissenters suffered from these laws varied, it is clear that the Restoration dissenters felt persecuted by the reestablished Church of England and Parliament. The Presbyterians lamented that St. Bartholomew's Day in 1662 when the Act of Uniformity came into force was 'the killing day for all the Nonconformist ministers' and were worried that this 'fatal act' would 'strike dead most of the godly ministers in England'. ${ }^{70}$

In some cases, the direct link between Catholicism and Antichrist was denied by Nonconformists. The moderate Presbyterian Richard Baxter, for instance, cast doubt on the identification of Catholicism with Antichrist. In disagreement with More, Baxter was reluctant to assert that the Roman Church was antichristian. In his comments on the New Testament, Baxter provided a brief account of competing

\footnotetext{
${ }^{67}$ Ibid., 229-30.

${ }^{68}$ Ian Atherton, 'Cathedrals and the British Revolution', in The Experience of Revolution in Stuart Britain and Ireland, eds., Michael J. Braddick and David L. Smith (Cambridge: Cambridge University Press, 2011), 104.

${ }^{69}$. Arthur William Wainwright, Mysterious Apocalypse: Interpreting the Book of Revelation (Nashville: Abingdon Press, 1993), 63-4.

70 Oliver Heywood, The Whole Works of the Rev. Oliver Heywood, Now First Collected, Revised, and Arranged, ed., John Vint (Edinburgh, 1827), 155; Spurr, The Post-Reformation: Religion, Politics and Society in Britain, 1603-1714 (Harlow: Longman, 2006), 150.
} 
interpretations of Antichrist. ${ }^{71}$ In so doing, he intended to show that there had been different opinions over the identity of Antichrist. Even though he acknowledged that most Protestants believed that the Catholic Church was Antichrist, he required readers to take heed of accepting this claim without consideration. In his response to Bishop George Downame, Baxter wrote as follows:

For my selfe, 1. I can better try him [Downame] by the plain parts of Scripture, than by the hard Prophecies. And I can easily see many and great pints in which Popery is contrary to the Word of God, and I am most moved by such Moral Arguments as Dr. Henry More useth in his Mystery of Iniquity. And I find enough to settle me against Popery. 2. But whether it be he that this Text meaneth, or those applied to him in the Revelation, I have not skill enough to be sure, or very confident. ${ }^{72}$

Baxter avoided an articulation of the definition of Antichrist by writing that 'a Christian may be very safe without understanding these obscure Texts: I long to know God and Jesus Christ better, more than to know Antichrist ... I think it my duty to confess my Ignorance, and not pretend to the Knowledge which I have not' ${ }^{73}$

In his apocalyptic work in 1670, The Cure of Church-Divisions, as noted above, Baxter disagreed with More on the identification of Antichrist. Baxter was hesitant to assert a connection between Catholicism and Antichrist, writing that:

if the Roman Kingdom (for so it is rather to be called than a Church) had not such Moral marks of Antichristianity, (which Dr. More hath notably opened in his Mysterie of iniquity;) if they were not the Engineers for the Division of the Christian world; by a false Centre, and by impossible terms of Unity, and by the engine of tearing dividing impositions; if among them were not found the blood of the Saints and the Martyrs of Jesus, I should in charity, fear to suspect them of Antichristianity, notwithstanding all the Propheticall passages which seem otherwise to point them out; because I should still

\footnotetext{
${ }^{71}$ Baxter mentioned Hugo Grotius and Henry Hammond's opinions different from the identification of Antichrist of the majority of Protestants. See William M. Lamont, Richard Baxter and the Millennium: Protestant Imperialism and the English Revolution (London: Croom Helm, 1979), chaps 1 and 4. For more about Hammond's claim see Jeffrey K. Jue, Heaven Upon Earth: Joseph Mede (1586-1638) and the Legacy of Millenarianism (Dordrecht: Springer, 2006), 150-55. On Grotius' view on Antichrist, see Johannes van den Berg, Religious Currents and Cross-Currents: Essays on Early Modern Protestantism and the Protestant Enlightenment (Leiden: Brill, 1999), 103-16.

${ }^{72}$ Richard Baxter, A Paraphrase on the New Testament, with Notes, Doctrinal and Practical (London, 1685), sig. uuu4r.

${ }^{73}$ Ibid., sig. uuu4r-uuu4v.
} 
suspect my understanding of those Prophesies, when the Law of Loving my neighbor as my self, is plain to all. ${ }^{74}$

Anglicans blamed these Nonconformists for understanding apocalyptic terms in a wrong way. More was critical of Baxter's apocalyptic interpretation. He wrote that Baxter 'read Mr. Durham, Dr. More, Grotius, and Dr. Hammond, but withal he confesses he did it superficially'. More saw Baxter as a 'Humorist' who admitted that the papacy took all of the traits ascribed to Antichrist, but who denied that 'this strange Degeneracy of the Church to be prefigured in a Book of Prophecies, the Apocalypse'. ${ }^{75}$ More's criticism was echoed by others. Daniel Nicols the rector of Scotton, Lincolnshire also complained in a sermon preached in 1681 that some dissenters were teaching the laity that 'our Liturgy is Popery, that our Ministers are Antichristian, that we have all received the mark of Beast'. ${ }^{76}$

Simon Patrick noted that the charge of Antichristianism was frequently made against the Church of England by Nonconformists. In his Continuation of the Friendly Debate published in 1669, Patrick mentioned that Nonconformists frequently and acrimoniously condemned conformists for having the elements of Antichristian practices laid down by their Church. Patrick was well aware of the Nonconformist claim that 'we [conformists] are Popishly affected, of an Antichristan spirit, and imitate Idolaters' ${ }^{77} \mathrm{He}$ acknowledged that when the predecessors of the Nonconformists came up against Charles I during the 1640s, they called the Church of England 'Antichristian, the Popish Party, the Gentiles, and Nations; the followers of the Dragon and such like Names' while they thought themselves to be 'the Witnesses of Christ Jesus, the Godly Party, the Saints that are to rule the Nations, with a rod of Iron; the followers of the Lamb, who are to ascend to Heaven, the Seat of Justice, and do execution upon us' ${ }^{78}$ This was well-known to Stillingfleet too. Stillingfleet's 'Fanatic Chaplain', who represented Nonconformists, accused the conformists of being 'the younger sister to the Whore of Babylon' for their 'idolatry of the English Popish Ceremonies' which remained in the Church of England. ${ }^{79}$

\footnotetext{
${ }^{74}$ Baxter, The Cure of Church-Divisions (London, 1670), sig. a7v-a8r.

75 More, Some Cursory Reflections Impartially Made Upon Mr. Richard Baxter His Way of Writing Notes on the Apocalypse, and Upon His Advertisement and Postcript (London, 1685), 8, 13-4.

${ }_{77}$ Daniel Nicols, A Sermon Preach'd in the Cathedral of Lincoln, July XVIII, 1681 (London, 1681), sig. A3v.

77 Patrick, A Continuation of the Friendly Debate by the Same Author (London, 1669), 30.

${ }^{78}$ Ibid., 71.

79 Stillingfleet, Several Conferences between a Romish Priest, a Fanatick Chaplain, and a Divine of the Church of England (London, 1679), 37.
} 
Patrick rejected the Nonconformists' charge of Antichrist against the Church of England, arguing that 'the Worship of God among us is lawful, and far from being Antichristian, ${ }^{80}$ In so doing, Patrick indirectly imputed the charge of antichrist to Roman priests. He disagreed with the criticism that conformists followed idolatrous practices introduced by the Roman Church.

The disagreements ran across Protestant denominations and traditions. It is interesting to note that many Protestant thinkers, for example, the Calvinist theologian John Owen, thought Baxter's approach to the identity of Antichrist was suspect. They accused those who did not hold to the traditional Protestant assumption of falling into the same errors at the Catholics about the identity of Antichrist. In fact, Baxter's identification of Antichrist with Roman pagans was regarded as being similar to Bellarmine's claim. Tillotson spoke of this kind of interpretation, saying that 'they of the Church of Rome would have it to be only Rome Pagan'. But 'This can be nothing else', he affirmed, 'but Rome Papal, to which the ten kings are said to give their power, and to which they were in a most servile manner subject for several ages, as is plain from history'. ${ }^{81}$

Some Anglicans asserted that Antichrist exploited not only Catholics but also radical enthusiasts and fanatics in order to persecute the true church. For them the period of the Civil War was a time when those sectarians played a significant role in enabling Antichristian forces to foment apocalyptic troubles in England. They viewed the period of the Interregnum as an age under the control of Antichrist. Abraham Nelson, a royalist, for instance, depicted that there was 'the time of Antichrist and his false prophets' in his Perfect Description of Antichrist (1660). ${ }^{82}$ Gryffith Williams, the bishop of Ossory, wrote The Great Antichrist Revealed in 1660 with the similar intention of claiming that 'the Acts and Doings of the Great Antichrist' were unequivocally discovered during the Interregnum from the 1640s. ${ }^{83}$

\footnotetext{
${ }^{80}$ Patrick, A Friendly Debate between a Conformist and a Non-Conformist (London, 1669), 204, 35.

81 Tillotson, 'Sermon XXVI: The Blessedness of Good Men, after Death', in The Works of the Most Reverend Dr. John Tillotson, vol. 4 (Dublin, 1739), 419.

${ }_{82}$ Abraham Nelson, A Perfect Description of Antichrist (London, 1660), sig. a3v.

${ }^{83}$ Griffith Williams, The Great Antichrist Revealed, before This Time, Never Discovered (London, 1660), chap. 2:13; Johnston, 'The Anglican Apocalypse in Restoration England', 472.
} 


\subsection{The History of the Church's Degeneration}

At a higher level, the rhetoric of anti-popery was related to the attack on the historical process by which the Roman Catholic faith and practices had been introduced into Christianity. For Anglican controversialists, the discovery of the historical roots of Catholic errors was a powerful weapon. The latitudinarians weighed the relative importance of the historical processes leading to the institutionalization of corrupt and idolatrous forms of practices in the Church of Rome. This was especially the case when it came to the competing interpretations of Antichrist. All the latitudinarians shared the common perception that the pope and the Roman church was Antichrist, but their analysis of the historical path by which that Church became antichristian was crucial to them. An historical explanation of the coming of Antichrist would strengthen their criticism of Roman Catholicism. During the seventeenth century many theologians or bishops found powerful images in the Book of Revelation which foreshadowed the histories of the false and the true church: the Dragon pursuing the true church into the wilderness (ch. 12); the Beast waging against the Lamb (ch. 13); the Whore of Babylon, 'drunken with the blood of the saints' (ch. 17). ${ }^{84}$ Furthermore, they could find a way to vindicate the religious legacies of the Reformation by repudiating the medieval church, and connecting the primitive church to the innovations of the Reformation. This scheme, therefore, was fundamental to both the radicals and moderates among the Protestant camp.

The latitudinarians' anti-papal concern was not radical in early modern terms. Henry More, for instance, did not identify the whole history of Christianity until the Reformation as an antichristian period, but rather believed that the purity, charity and simplicity of the primitive church had been restored. In his calculation of the period of time of the reign of Antichrist which is 1260 years, Philip C. Almond clearly shows that More drew a distinction between the pure Christian in the apostolic Church and 'Rome pagano-christian', and was convinced that the Church had not become antichristian until around A.D.400, until which time it had been balanced. ${ }^{85}$ For More, this reinforced the link between the Roman church and the Roman empire. He devoted many pages to explaining the connections of the Roman Catholic to the Roman Empire, tracing how the primitive church became idolatrous. Christianity,

\footnotetext{
${ }^{84}$ Coffey, Persecution and Toleration in Protestant England, 1558-1689, 59.

85 Philip C. Almond, 'Henry More and the Apocalypse', Journal of the History of Ideas 54, no. 2 (1993): 194.
} 
from the reign of Julius to Constantine, was the primitive church. But after the conversion of Constantine in 432, the empire became 'Paganochristian', and then imposed 'the old Paganick Idolatries upon the people' under the pretence of Christianity. By considering some coincidences of the newly-invented practices of the Roman church with ancient paganism, More tried to demonstrate the incorporation of pagan tradition into Christianity. According to him, 'the ancient Heathen burnt incense to their Gods, which is a consumptive Sacrifice, ... so does the Church of Rome burn Incense before the Images of her Saints, and make this kind of Sacrifice to them'. ${ }^{86}$ It is sure, More concluded, that 'the state of the Roman Church bears a relationship to ancient Paganism in Idolatry, Superstition and Cruelty'. ${ }^{87}$ In so doing, More made it clear that the 'Whore of Babylon' or 'twohorned beast' - the pope - would have had the imperial power of an emperor and hence obtained the assistance of the dragon. The church then became 'the worshipper of Devil'. ${ }^{88}$ The anti-papal rhetoric in More's writings ultimately led to the hope of the demolition of the papal hierarchy in accordance with the prophecies. In addition to this, historical events, like the Reformation and the Restoration, confirmed for him the veracity of apocalypse. But this was not the end of the apocalyptic story. More needed to understand the status quo in his time through the mirror of apocalyptic interpretations.

Burnet also demonstrated the historical process by which the Roman church had been alienated from the primitive spirit by Antichrist. He argued that after Christianity became the state religion by the official permission of the Roman Empire, Christians accommodated themselves to heathen customs in order to make Christianity comply with the pagan world. Thus they offered worship to the apostles and to other saints in a pagan way. Burnet asserted that the Christians built 'Babylonish Rome', as the heathens built temples for their Gods. For example, the Pantheon at Rome, dedicated to Cybele, the mother of Gods, in the Augustan age, was afterwards consecrated to the Virgin and all the saints. ${ }^{89}$ Consequently, for Burnet, the history of Christianity proved that all kinds of idolatrous customs had crept into Christianity.

\footnotetext{
${ }^{86}$ More, Synopsis Prophetica; or, the Second Part of the Enquiry into the Mystery of Iniquity, 327.

${ }^{87}$ Ibid., 335.

${ }^{88}$ More, Apocalypsis Apocalypseos; or the Revelation of St John the Divine Unveiled, 125-26, 172.

89 Burnet, The Mystery of Iniquity Unveiled in a Discourse, Wherein Is Held Forth the Opposition of the Doctrine, Worship, and Practices of the Roman Church, 25-6.
} 
How had the pope and the Roman institution become corrupted? Burnet ascribed all these external inventions to papal avarice. While 'religion and reason', he said, 'had lien out of the way, interest and ambition had withstood this'. ${ }^{90}$ In a word, 'humane infirmity' made the church pander to heathenish rites instead of 'the Primitive simplicity of the faith and worship of the Christians'. ${ }^{91}$ However, attributing the papal break with primitive tradition to the flawed nature of human being was not a fully satisfactory explanation. In Burnet's historiography, the decisive moment was when Christianity, tinged with pagan practices, then adopted and kept up 'idolatrous' customs. In his work, 'Gentilism' was one of the key terms used to describe the idolatrous practices and false notions of the Church of Rome. ${ }^{92}$

Like Burnet, Stillingfleet's main argument against the Catholics was based upon the simple assumption that historical investigation and demonstration based upon the Scripture indicated that Rome was Antichrist. The 'Primitive Fathers', Stillingfleet said, 'disputed against the Heathen Idolatry' because of God's Commandments. Despite the Primitive Fathers' condemnation of idolatrous worship, he claimed, the Roman Church consistently accepted a heathenish style of worship. In the Fathers' words at the Nicene Council,

That the Devil now, not being able to reduce the world to the former Idolatry, endeavours under hand to introduce it, under a pretence of Christianity, bringing them again to the worship of the creature, and making a God of a thing that is made, when they have called it by the name of Christ. $^{93}$

Stillingfleet explored the theological grounds on which the Catholics claimed their authority for infallibility and for the traditions which the apostles had delivered to the popes. He confidently assumed that these two things led the Roman church onto the path to idolatry. He viewed these grounds as absurd not only because the truth of the Scriptures revealed the falsehood of papal infallibility but also because the history of Christianity showed that there was no tradition in favour of the Roman Church. He offered as an example the history of the Council of Constantinople's prohibition of the use of Christ's image. Thus it was proved, he thought, that there was no tradition passed down from Christ or his apostles, or the primitive Fathers, for a superstition

\footnotetext{
90 Ibid., 122.

${ }^{91}$ Ibid., 122-23.

92 See Chapter 3, section 2 below.

${ }^{93}$ Stillingfleet, A Discourse Concerning the Idolatry Practised in the Church of Rome, 68-9.
} 
which Catholicism had promoted. ${ }^{94}$ The discovery of the historical roots of Catholic errors was a powerful weapon for Anglican controversialists. They believed that they could effectively show that Catholic idolatry was a denial of the original characteristics of the Primitive Church.

Patrick explained that the pure state of the primitive church did not last as long as might have been expected since 'the plain, simple Doctrine of Christ' was perverted and turned into 'a foul Apostasie as we now see in the Church of Rome'. He sees the first three hundred years of Christianity as not having a persecuting spirit. However, 'imposition upon Mens Understandings' by 'inflicting corporal Punishments merely for false opinions came in with the Retinue and Train of Antichrist'. ${ }^{95}$ In another sermon, Patrick repeated that 'those happy days in the beginning of our Religion ... were of so short continuance; and the days are, long ago, become exceeding evil' by imputing this to 'the corruption of Christian doctrine, to the invention of new articles of faith, and to the over-zealous espousal of those opinions'.96

The latitudinarian controversialist Edward Fowler wrote that 'for many years after our Saviour and his Apostles, did the temper and spirit we have been describing, mightily prevail: but as the Christian World grew worse and worse, which was especially after it came to be freed from Persecution, ... it more and more decayed'. His dismal summary of church history ended with the expressing of his desire that 'we shall not much longer wait for the downfall of the Visible Antichrist'. ${ }^{97}$ These statements were part of his defence of the Church of England against Nonconformist claims that the Church was too close to the spirit and practice of Roman Catholicism.

There was an equally long tradition of debate among the seventeenth-century 'godly' or puritans and their nonconformist heirs as to whether the Church of England was popish. While English puritans regarded the Catholic Church as an antichristian false church, they were perplexed with doubts as to the Church of England. For many puritans Anglicans shared a great deal with their avowed enemy,

\footnotetext{
94 Ibid., 48, 73, 124.

95 Patrick, A Sermon Preached at St. Paul's Covent-Garden on the First Sunday in Lent (London, 1689), 19-20.

${ }^{96}$ Patrick, A Sermon Preached in the Chappel of St. James's before His Highness the Prince of Orange, the 20th of January, 1688, 31.

97 Edward Fowler, The Principles and Practices of Certain Moderate Divines of the Church of England (London, 1670), 343-45.
} 
the Church of Rome. ${ }^{98}$ As Anthony Milton observes, early seventeenth-century puritans believed that 'opposition to popery was thus ipso facto godly; the puritan commitment to further reformation implied a constant state of conflict with the forces represented by the papal enemy'. ${ }^{99}$

Given that Patrick and Fowler's works were intended to defend the principles and faith of the Church of England from the Nonconformist attack, the historical explanation of Roman corruption could serve to unite the Church of England and other Protestant denominations against the common Roman Catholic enemy. Patrick charged Nonconformist adversaries to be very careful in their use of apocalyptic terms in their attack on the Church of England because 'it would be more for the Interest of Christianity' if they would 'cease to undermine each other, and both joyn together to promote sound Religion and true piety'. ${ }^{100}$ For them, Nonconformist attacks on conformist brethren, with their fanatic use of apocalyptic language, undermined the foundations of religion.

\subsection{Moderate Apocalyptic Thought}

Given that apocalyptic terms played a key role in anti-popery sentiment among the latitudinarians, as discussed above, it is surprising that there are only a few works on the apocalypse published by latitudinarian divines. As a consequence many historians place little stress on their apocalyptic ideas. It has been argued that More and Burnet were as preoccupied with the rise and destruction of Antichrist and its impact on the Protestant Church as their fellow Protestants, but that the anti-popish rhetoric of other moderate Anglicans was not particularly related to the interpretation of prophecies.

However, this is not true. The latitudinarians believed in the apocalyptic tension between true and false forces in human history, dramatising the significance of the Reformation as the work of God's providence in the defeat of the Antichristian church. They embraced the apocalyptic tradition in their identification of Antichrist, though they might not have presented the detailed analysis of prophetic images and texts in lengthy volumes. Seeing that latitudinarian divines agreed with fellow

\footnotetext{
98 Spurr, The Restoration Church of England, 1646-1689 (New Haven: Yale University Press, 1991), 111.

99 Anthony Milton, Catholic and Reformed: The Roman and Protestant Churches in English Protestant Thought, 1600-1640 (Cambridge: Cambridge University Press, 1995), 36.

${ }^{100}$ Patrick, A Friendly Debate between a Conformist and a Non-Conformist, 203.
} 
Anglicans on the connection of Antichrist with the Catholic Church, there is one significant issue to be discussed: in what way did they interpret the nature of Antichrist and the apocalypse from their own moderate perspective?

One of the main features of their apocalyptic views is seen in their reticent and cautious way of dealing with the prophecies. The Anglican apocalyptic view was rooted in the apocalyptic framework shared with other Protestants, but latitudinarians exercised caution when it came to spelling out the detailed applications of prophecies. They were wary of the radical and puritan abuse of apocalyptic thought. They presented a different application of apocalyptic thought to English society. As Johnston argues, the use of apocalyptic rhetoric to support the puritan cause during the Civil War period provoked many reactions from Anglican polemicists who used similar apocalyptic convictions for promoting the existing religious establishment and the role of English monarch. ${ }^{101}$ What worried them about apocalyptic exegesis was the unreasonableness of the radicals' understanding of the apocalypse. The latitudinarians' use of apocalyptic rhetoric was limited to the interpretation of some images over which there was general agreement by most Protestants. They did not generally address controversial issues in their interpretations. In his analysis of the nature of the Babylonian beast, Tillotson did not go so far as some supporters of apocalyptic thought. 'I shall not presume to conjecture', said he, 'much less positively to determine, whether he be now in being; because it is said to require a particular wisdom and understanding to find it out'. Without articulation of apocalyptic texts, Tillotson concluded that 'the event, when the thing is fully accomplish'd, will clearly discover it'. ${ }^{102}$

In addition to their cautious approach to prophecies, latitudinarians were also distinguished by their attitude to the return of Christ to rule on earth. One of main differences between the latitudinarians' and radical Nonconformists' apocalyptic thought was, as Paul J. Korshin shows, that the former did not expect the imminent arrival of Christ in this world. ${ }^{103}$ The latitudinarians' apocalyptic expectation of the end of the world was quite different to the future hope of the radicals. For example, it is obvious that More did not expect, as Philip Almond suggests, an imminent return

\footnotetext{
101 Johnston, Revelation Restored: The Apocalypse in Later Seventeenth-Century England, 125-26.

102 Tillotson, 'Sermon XXVI: The Blessedness of Good Men, after Death', 421.

103 Paul J. Korshin, 'Queuing and Waiting: The Apocalypse in England, 1660-1715', in The Apocalypse in English Renaissance Thought and Literature: Patterns, Antecedents, and Repercussions, eds., Constantinos Apostolos Patrides and Joseph Anthony Wittreich (Ithaca, N.Y: Cornell University Press, 1984), 242.
} 
of Christ nor a reign upon earth for a thousand years. According to him, the thousand-year rule of Christ would be in heaven rather than in this world. ${ }^{104}$ Like More, the latitudinarians rejected the radical interpretation of the prophecies. Although they did not agree with the radicals' version of apocalypse, nevertheless their writings certainly reveal that they believed in the destruction of Antichrist and the deliverance of the true church from the false in the near future. Discovering the nature of the end of Christianity, More was confident that eternal happiness would be brought, and that the world would be redeemed 'out of the dominion and tyranny of the Devil', and that finally, Christ would be worshipped 'as the lawfull owner of all Sovereignty in Heaven and in Earth'. ${ }^{105}$ It seems that More thought that the Reformation initiated the time when the power of Antichrist started to decline, writing that 'this has been done in its measure in the Reformation, when so many Kingdoms and Principalities forsook the Church of Rome'. ${ }^{106}$ Stillingfleet also had an optimistic view of the future. He claimed that the course of Christian history was destined to embark on the ruin of the antichristian kingdom and faith, through the providence of God. The Scriptures proved, he wrote, that 'the Devils Kingdom cannot stand, if it be divided against it self'. ${ }^{107}$

The destruction of the antichristian church was associated with the emphasis on a providential peace, unity and happiness. Unity and love were two important keywords in Patrick's sermons on the accomplishment of divine providence on earth. Patrick stressed the need for unity in English society. He asserted that everyone should participate in God's providential plan for the destiny of his true church: 'Princes and Governours should study this, by making just, reasonable, and merciful laws; and the people should study it, by a humble submission to them, and careful observance of them'. ${ }^{108}$ Patrick's works display the full expectation of a new world and his apocalyptic ideas guaranteed the ultimate accomplishment of God's providence. In his exegesis of Isaiah 11:6, Patrick understands that this prophecy shows not only that humans who were full of hatred before Christ's coming, 'in the days of Christ should become new Creatures', but also that 'the apostate church will

\footnotetext{
104 Almond, 'Henry More and the Apocalypse', 198.

105 More, An Explanation of the Grand Mystery of Godliness (London, 1660), 97.

106 More, Apocalypsis Apocalypseos; or the Revelation of St John the Divine Unveiled, 177.

107 Stillingfleet, A Discourse Concerning the Idolatry Practised in the Church of Rome, 342-43.

108 Patrick, A Sermon Preached in the Chappel of St. James's before His Highness the Prince of Orange, the 20th of January, 1688, 34-5.
} 
be thrown down and with the destruction of this mystical Babylon, the Christian World shall be renewed'. ${ }^{109}$ Even though Patrick expressed hope of revenge against their enemy, the latitudinarians in general did not support violence in the destruction of Antichrist. Patrick's expectation of future happiness was expressed by his description that 'the abundance of truth and peace, by a right understanding of the Will of God, and an hearty Submission thereunto, and the earth full of the knowledge of the Lord ... as the Waters cover the Sea'. ${ }^{110}$ As Patrick's sermons during the Revolution were full of a desire of religious unity, he emphasized the 'Lamb-like Disposition' for seeing such unity. For this purpose Protestants should subdue 'all your unruly Appetites and Passions', and purge 'your Choler and Gall, all Anger, Malice, and desire of Revenge' by which the world was 'now miserably divided and disturbed'. ${ }^{111}$ In another work, he expected that when the kingdom of Christ 'doth come, it will be with a vengeance to the Roman Church, whose present state will be utterly overturned, to make way for the setting up of Christ's Universal and Everlasting Kingdom'. ${ }^{112}$ Patrick's interpretation of the providence of God encouraged obedience to the precepts of Christianity until the fulfilment of prophecy. What needs to be done, he said, was to maintain a desire for unity and felicity. A 'plenty' of knowledge of Jesus Christ, he emphasised, makes men and the world happy. $^{113}$

Such an irenic and moderate outlook had other facets. It is noticeable that the latitudinarians, like many of their contemporaries, drew a distinction between the international and impersonal forces of Antichrist and popery and their lay Catholic neighbours. As John Miller claims, there was 'a certain ambivalence in Protestant attitudes towards Catholicism and Catholics'. English Protestants saw a distinction between 'Popery as a malign political force and Papists as people'. ${ }^{114}$ Many Protestants could distinguish in their own minds between the pope and high priests in the hierarchy of the Roman Church and the ordinary members of the Church. This

\footnotetext{
109 Patrick, A Sermon Preached at St. Paul's Covent-Garden on the First Sunday in Lent, 10, 20.

${ }^{110}$ Patrick, A Sermon Preached in the Chappel of St. James's before His Highness the Prince of Orange, the 20th of January, 1688, 31-2.

${ }_{111}$ Patrick, A Sermon Preached at St. Paul's Covent-Garden on the First Sunday in Lent, 29.

112 Patrick, An Answer to a Book, Spread Abroad by the Romish Priests, Intituled, the Touchstone of the Reformed Gospel Wherein the True Doctrine of the Church of England and Many Texts of the Holy Scripture Are Faithfully Explained, 54-5.

${ }^{113}$ Patrick, A Sermon Preached in the Chappel of St. James's before His Highness the Prince of Orange, the 20th of January, 1688, 28; A Sermon Preached at St. Paul's Covent-Garden on the First Sunday in Lent, 26.

${ }_{114}$ John Miller, Popery and Politics in England, 1660-1688 (London: Cambridge University Press, 1973), 58.
} 
indicates that these Anglicans found the question of the nature of Antichrist troubling. It also demonstrates a degree of sympathy for those lay people who were the victims of Antichrist. They criticised Catholic priests for seducing the people into converting to the Roman Church. In his Mystery of Iniquity, Burnet thought that the forms of worship in the Church of Rome were 'contrary both to the Divine Essence and Command', being used as 'a snare to the vulgar, who will be ready to think God like upon it'. ${ }^{115}$ Burnet's work attempted to warn the laity that the doctrines and practices of the Catholic Church would lead her believers into ignorance and a blindness to her false nature.

In his description of one of the prophetic images, Henry More insisted that 'the Beast that was, and is not, and yet is, is the Roman Empire, and the Woman that rides him, the Roman Hierarchy'. In other works he referred to the pope, who made himself the head of the Church and 'cut off Jesus from being its head, and thereby discovers himself to be that notorious Antichrist in Christendom'. ${ }^{116}$ Others also specified the definition of Antichrist. Edward Stillingfleet took note of the religious orders of the Roman Church. These religious orders were organised by zealous Catholics. He pointed out that the Benedictines, Carthusians, Dominicans, Franciscans and Jesuits were the most celebrated orders in the Roman church in his time. ${ }^{117}$ Moreover, it seems that he assumed that there was no salvation possible for hypocrites or those who committed to idolatrous sins because of their 'sins inconsistent with salvation'. ${ }^{118}$ For Patrick, Antichrist was not a particular man, but the current ruling power in the Roman Church, as the Book of Revelation describes. ${ }^{119}$ John Tillotson did not identify every individual who was in the Roman communion with Antichrist, but rather their doctrines and principles, and the heads of their church. He acknowledged that the great piety and charity of several persons who had lived and died in that communion, such as Erasmus, Thuarus and others. 'I am confident', he preached, 'tis very true, that many Papists would have been

\footnotetext{
115 Burnet, The Mystery of Iniquity Unveiled in a Discourse, Wherein Is Held Forth the Opposition of the Doctrine, Worship, and Practices of the Roman Church, 17.

${ }^{116}$ More, Apocalypsis Apocalypseos; or the Revelation of St John the Divine Unveiled, x-xi; Synopsis Prophetica; or, the Second Part of the Enquiry into the Mystery of Iniquity, 208; A Plain and Continued Expeosition of the Several Prophecies, xlvi, 46.

${ }^{117}$ Stillingfleet, A Discourse Concerning the Idolatry Practised in the Church of Rome, 227.

118 Ibid., 46

119 Patrick, An Answer to a Book, Spread Abroad by the Romish Priests, Intituled, the Touchstone of the Reformed Gospel Wherein the True Doctrine of the Church of England and Many Texts of the Holy Scripture Are Faithfully Explained, 88-9.
} 
excellent persons and very good men'. ${ }^{120}$ The question of whether the gullible and good lay members of the Antichristian Catholic Church were excluded from all hope of salvation was of major concern to the moderate and rational latitudinarian divines. The issue turned upon whether the Church of Rome was a true church or not.

\subsection{The Possibility of the Salvation of Roman Catholics}

Anti-popery in latitudinarian Anglican literature placed an emphasis on the process of the historical corruption of the Roman Catholic Church. The great question was whether that corruption had left the Antichristian Roman Church so corrupt that it could offer its members no hope of salvation. By means of a meticulous survey of Gilbert Burnet's theology, Tony Claydon shows that Burnet's attitude towards Catholicism was based upon his moderate and apocalyptic world-view. It is worth taking note of his description of the sincerity of Burnet's anti-Catholicism, given that Burnet insistied that the Roman Church was Antichrist. According to Claydon, many of Burnet's works were in line with his anti-Catholic sentiment, but that his true views were, in fact, subtly different from what many have understood. Claydon argues that Burnet occasionally described the Roman Church as part of the true communion led by Christ, although remaining deeply corrupt, and, furthermore, Burnet accepted that those within the Roman establishment could gain salvation. ${ }^{121}$ Once it is admitted that Catholicism was not itself hopeless, what then would Burnet have meant by the corrupt of a false church? Claydon claims that it was religious persecution that Burnet regarded as identifying a false church because the terror of persecution was an essential part of his anti-papal polemic.

Claydon's explanation, however, should be reconsidered. Burnet's identification of Catholicism with Antichrist, as Claydon says, was a main emphasis in much of his writings. In contrast to Claydon's argument, nevertheless, Burnet did not really intend to admit the possibility of salvation in the Roman Church. Although Burnet seemed to concede that the Catholic Church could be the true church, he consistently asserted that men could not achieve salvation in the current Roman Church. In other works, what he wrote is quite different. Burnet's concession needs

\footnotetext{
120 Tillotson, A Sermon Preached before the Honourable House of Commons, Novemb 5, 1678 (London, 1678), 28-9.

${ }^{121}$ Claydon, 'Latitudinarianism and Apocalyptic History in the Worldview of Gilbert Burnet, 1643-1715', 589.
} 
to be read within the context of all his books. His mentioning of Catholicism as a true church was part of his rhetoric while emphasising the defects and errors of its doctrines, and vindicating the principles of the Reformed church. In his Unreasonableness and Impiety of Popery (1678), for example, Burnet said, 'though we acknowledge the Church of Rome a true Church, yet we may examine her Doctrines, and separate from her errors', and then he went on to examine some underlying prejudices of the Roman church. ${ }^{122}$ Elsewhere in the same work, Burnet claimed that 'though we yield ... a possibility of Salvation in that Church, we declare that they are in great danger, by many opinions among them, which if fully understood and believed, do even vitiate the Essentials of Christianity'. So he thought it could be declared that 'a Certainty of Salvation to those who sincerely follow the rules of our Church, and a great danger in their Church, the preferring their Communion to ours, upon this account, is, as unreasonable, as to sleep without shutting our Doors'. It is reasonable to understand, therefore, that he actually did not deny that the Roman Catholic Church could be a true church and a route to salvation, but sought to repudiate its doctrines. Instead Burnet appears to assume that the main reason why the Roman Church was identified with Antichrist was because of its hierarchical system. If someone retains the essentials of Christianity, he or she may be saved by God, even if a member of the Catholic Church. As he put it, 'our concession amounts rather to this, that we do not deny it, than that we positively affirm it'. ${ }^{123}$

Burnet, however, had a different view of the Roman Catholic laity. These were to be helped by the charity of Protestants. He clearly insisted on charity to enemies or persecutors. He asked the readers to remember that 'we must not bound our Charity within so narrow a compass, ... and therefore we must not only love our Brethren, but even our Enemies and our Persecutors, and so overcome their evil with good'. Burnet thought that the spirit of the Roman Church had overawed many of its people who had not the strength of thought to look into it, so that they were 'shut up blindfold and muffled up with the awful bonds of Authority and Infallibility' ${ }^{2}$

\footnotetext{
122 Burnet, The Unreasonableness and Impiety of Popery, 6.

${ }^{123}$ Ibid., 25.

124 Burnet, A Sermon Preached in the Chappel of St. James's, before His Highness the Prince of Orange, the 23d of December, 1688 (London, 1689), 14-5.
} 
Burnet's dualism of anti-Catholicism with respect to his definition of Antichrist shows his moderate attitudes towards the Catholic laity. He allowed the possibility that the Catholic laity could return to Protestantism. Although the Restoration asserted the re-establishment of the Church of England over Englishmen, the work of reformation continued. In local parishes, Catholics were on good terms with Anglicans, though their numbers were very small during the period 1660-88 when anti-Catholicism became intense. ${ }^{125}$ In this situation, like other Anglicans, Burnet tried to soften and limit his animosity to Catholics in order to convince the Catholic laity to convert to Protestantism.

The issue of the range of application of the apocalyptic word, Antichrist, was closely linked to the problem of salvation. This issue involved not only theological debate but also pastoral care. Protestants shared a strongly felt need for rejecting the possibility of salvation in the Church of Rome in order to cope with the Catholic threat. The possibility of salvation for those who left the Protestant Church was discussed by Stillingfleet in his Discourse Concerning the Idolatry. Stillingfleet concluded that the worship of God by images, as performed by Catholics, must be punished according to the Second Commandment. He asserted that those who were in the Church of Rome did 'run so great a hazard of their salvation'. ${ }^{126}$ In his Several Conferences, he admitted the possibility of salvation for papists by citing the arguments of the bishop of Lincoln, Robert Sanderson (1587-1663). Stillingfleet had 'hope charitably of many thousands poor souls in Italy, Spain and other parts of the Christian World at this day' that they might 'attain mercy and salvation in the end, although in the mean time through ignorance they defile themselves with much foul Idolatry, and many gross superstition'. ${ }^{127}$

These latitudinarians thought the Catholic laity could gain salvation by divine grace only if they repented of their ignorance and endeavoured to give a complete obedience to the true and holy church. Stillingfleet's work seems to impact on some Catholics but his main aim was to give Protestants a strict warning not to leave the Protestant Church. Thomas Seymour, a goldsmith, confessed that he returned to the

\footnotetext{
125 Miller, Popery and Politics in England, 1660-1688, 66.

126 Stillingfleet, A Discourse Concerning the Idolatry Practised in the Church of Rome, 3.

127 Stillingfleet, Several Conferences between a Romish Priest, a Fanatick Chaplain, and a Divine of the Church of England, 153-54.
} 
Church of England after reading Stillingfleet, Tillotson, and William Lloyd. ${ }^{128}$ Their attempts to limit the use of the term Antichrist reveal the latitudinarian idea of Antichrist. As for the Catholic laity who were English subjects, they could be dealt with as individuals, not as part of the body of antichrist, once they were separated from the Church of Rome as Antichrist. With this approach, the Latitudinarians pursued religious unity and harmony under the Protestant ascendancy.

The latitudinarians' interpretations of the apocalypse are, in general, not far from removed from those of their contemporaries in that they dreamt that Antichrist would be vanquished by Christ, and that a new heaven would come to this world. Over the past few decades, many scholars have been inclined to concentrate on the latitudinarians' emphasis upon reason in religion and upon moral reform. The reason why they are important, as G. R. Cragg argues, is because they both registered and accentuated an important change in religious thought by exalting reason in the reaction against enthusiasm. ${ }^{129}$ It is useful to understand the innovative aspect of their thought in this way, but we need to remember that their theology was also based upon traditional modes of thought. Of course, the latitudinarians also connected and developed their apocalyptic ideas to justify the position of the Church of England as the authentic reformed church, and the authority of the civil magistrate, and to further the expectation of moral reform and the edification of lay people through reading the Scriptures written in English. These issues will all be dealt with in the following chapters.

\footnotetext{
128 Carroll, The Common-Sense Philosophy of Religion of Bishop Edward Stillingfleet, 1635-1699, 50.

129 Gerald R. Cragg, From Puritanism to the Age of Reason: A Study of Changes in Religious Thought within the Church of England, 1660 to 1700 (Cambridge: Cambridge University Press, 1950), 85-6.
} 


\section{Chapter 3 \\ The Apocalyptic Vision of the True Church and the Church of England}

This chapter explores the Latitudinarians' historical understanding of the Church of England in the context of their apocalyptic and providential thinking. It argues that their adoption of 'rational' or 'reasonable' interpretations of the history of the Christian church, and especially the history of the English Reformation and the Early or Primitive Church of the first centuries, should be seen in the context of an apocalyptic understanding of the struggle between the true and the false Church. In a diverse set of controversies about the history of the Christian church, the rule of faith, and the degeneration of the church under the medieval Papacy, the latitudinarian churchmen asserted the integrity of the Church of England as a 'true church'. They recognised that the Reformation was a work in progress. They understood divine providence as being an historical but not a uniformly linear process. They advanced a case that was both rational and mystical.

The controversies discussed in this chapter are mainly between moderate Anglicans and their Roman Catholic adversaries. However, it is important to recognise that the Restoration Church of England was attacked on all sides. Some of the arguments analysed here about the nature of the Reformation, the continuity of the Reformed Church of England with the primitive church of the first four centuries or the medieval Roman Catholic Church, and the providential persecution or martyrdom suffered by English Protestants, were relevant to the Church of England's disputes with other Protestant denominations. Historical debates about the origin, nature and authority of the Church of England were also at the heart of exchanges with the so-called 'Freethinkers', the rationalist critics of clerical authority. Justin Champion has studied the historiographical quarrel between Freethinkers who wished to demolish the authority of the priests and the Anglican clergy who defended the religious and political hegemony of the Anglican Church. Champion, then, argues that speculation on religion was central to Freethinkers who were thought to denigrate religious values, and shown that what they rejected was not religion itself, but 'the false Anglican monopoly of true religion', with the hope of pursuing political and religious toleration of indifferent things. Champion shows that in the 
eyes of the Freethinkers, religion was not antagonistic to reason, and 'true religion and reason became one and the same thing'.

The moderate Anglican clergymen discussed in this chapter were not only debating with Roman Catholics, Freethinkers and other Protestants, they were also deeply imbued with an apocalyptic and providential worldview. Like many of their fellow Anglicans and Protestants, the latitudinarians had inherited a language about divine providence and a set of apocalyptic assumptions. Warren Johnston's study of the Anglican tradition of apocalyptic ideas in the Restoration cites an abundance of apocalyptic writings by Anglican churchmen. Johnston speaks of the variation of Anglican interpretations of prophetical images in accordance with Restoration English conditions. ${ }^{2}$ Johnston demonstrates the continuity of the apocalyptic tradition in support of church and state. The examination of Henry More's apocalyptic exegesis on prophecies is a good example of Anglican understanding of the Church of England in apocalyptic history. Tony Claydon's article on Burnet's apocalyptic thought re-examines the existing assumptions about the latitudinarians. Claydon emphasises that Burnet's view on the Church of England should be read in terms of his apocalyptic worldview in which he found "providential cycle of the past'. ${ }^{3}$ These two historians similarly stress the continuous tradition of apocalyptic language in those 'rational' Anglican clergy who had been thought to have turned their back on such thinking.

The latitudinarians' interpretations of the Scripture's apocalyptic prophecies were distinct. They did not share all of the ideas and approaches of their predecessors: for example, John Tillotson did not agree with other Protestant apocalyptic writers who sought the specific date of the thousand-year reign of Christ (but avoided saying when the reign of Christ would start), but he was nonetheless certain that the glorious kingdom of Christ would appear on earth. He thought it was not yet time for the end of the world because the Jews were still dispersed over the world and the Gentiles had not yet converted themselves into Christianity. ${ }^{4}$ If the latitudinarians did not go

\footnotetext{
1 J. A. I. Champion, The Pillars of Priestcraft Shaken: The Church of England and Its Enemies, 1660-1730 (Cambridge: Cambridge University Press, 1992), 229-30.

2 Warren Johnston, 'The Anglican Apocalypse in Restoration England', The Journal of Ecclesiastical History 55, no. 3 (2004): 467-501.

${ }^{3}$ Claydon, 'Latitudinarianism and Apocalyptic History in the Worldview of Gilbert Burnet, 1643-1715', The Historical Journal 51, no. 3 (2008), 584.

4 John Tillotson, 'Sermon CXXXIX: The Evidence of Our Saviour's Resurrection', in The Works of the Reverend Dr. John Tillotson, vol. 8 (Dublin, 1739), 353.
} 
so far as to deal with the detailed analysis of apocalyptic images or the calculations of the measurement of prophetic days contained in the Scriptures, their historical study of the apocalyptic prophecies nevertheless hints that apocalyptic ideas underpinned their theology and ecclesiology.

This chapter will examine the way in which apocalyptic language was used by the latitudinarians in support of the Church of England. Their use of providential rhetoric was manifest in the controversy over the nature of true religion. The justification of the Church of England as a true church was an important theme in historical investigation into the establishment of the English Church.

The chapter, therefore, begins with some major latitudinarians' historical and apocalyptic narratives of the English Reformation of the sixteenth century. Their historical reconstruction of the Henrician Reformation and historical description of the corruption of the Roman Church, interestingly, reveals the nature of true religion which latitudinarians associated with the Church of England. Secondly, this chapter explores the relationship of the Church of England and the Primitive Church. The latitudinarian understanding of the history of the Reformation can be explained in terms of their assertion of the Church of England's 'primitivism' in contrast to the Church of Rome's 'superstition'. Their historical study enabled them to presuppose a model of reformed religion: the restoration of primitive virtues as exemplified by the Early Christian Church. The third section of this chapter concentrates upon the motives for further reformation. The latitudinarian apocalyptic view of the sixteenth century Reformation did not assume that the process was complete, but anticipated the further reformation to promote true religion. The dangers surrounding Protestantism on the European continent and in England under the Catholicsympathiser Charles II and the Catholic James II, were a strong incentive to further reformation.

\subsection{The Providential Historiography of the Reformation}

Throughout the seventeenth-century Anglican concern about the history of the Reformation was a commonplace. After the re-establishment of the Church of England and the monarchy from 1660, the discussion of the English Reformation was the unfinished business. While their historical view of the Reformation was 
mainly influenced by sixteenth-century forerunners' historical works, especially by John Foxe, there was also others adopted different approaches to historical arguments. ${ }^{5}$ A number of Anglican works addressed the English Reformation to vindicate the Church of England's independence from the Roman Church. William Lloyd, the close associate of these latitude-clergy, published A Seasonable Discourse shewing the necessity of Maintaining the Established Religion in Opposition to Popery. ${ }^{6}$ Peter Heylyn's histories of Tudor England's separation from Rome from the High Church perspective were attracted many people's attention. ${ }^{7}$ The publication of Protestant histories of the Reformation occurred in various forms of literature. This theme was not only limited to sermons and tracts but also appeared in biographical works like Ecclesiastical History Epitomized (1682) and visualized in images, such as a woodcut image in a broadsheet in $1680 .{ }^{8}$

Like other conformist apologists, many latitudinarians also got involved in the historical justification of the Church of England and the Reformation as part of the anti-Catholic scheme. In 1671, Stillingfleet wrote his A Discourse concerning the Idolatry practised in the Church of Roman. Two years later, Stillingfleet published $A$ Second Discourse in Vindication of the Protestant Grounds of Faith, and then preached a sermon entitled The Reformation justified in September. In the same year, Tillotson's sermon The Hazard of being saved in the Church of Rome was brought to the audience, and Burnet set forth Rome's Glory and The Mystery of Iniquity. ${ }^{9}$ The unsettled situation in religion demanded the justified history of the Reformation and the Protestant church. Like the seventeenth-century contemporaries, the latitudinarians concentrated their energies on historical method and writings. They implicitly agreed that history was a means of reaffirmation of the present religious

${ }^{5}$ On the variety of approaches and views of the Reformation, see John Spurr, “"A Special Kindness for Dead Bishops": The Church, History, and Testimony in Seventeenth-Century Protestantism', in The Uses of History in Early Modern England, ed., Paulina Kewes (San Marino, California: Huntington Library, 2006), 319-20.

${ }^{6}$ William Lloyd, A Seasonable Discourse Shewing the Necessity of Maintaining the Established Religion in Opposition to Popery (London, 1673).

7 J. E. Drabble, 'Gilbert Burnet and the History of the Einglish Reformation: The Historian and His Milieu', Journal of Religious History 12, no. 4 (1983): 352-53.

8 Alexandra Walsham, 'History, Memory, and the English Reformation', The Historical Journal 55, no. 4 (2012): 930-32.

${ }^{9}$ Edward Stillingfleet, A Discourse Concerning the Idolatry Practised in the Church of Rome; A Second Discourse in Vindication of the Protestant Grounds of Faith, against the Pretence of Infallibility in the Roman Church (London, 1673); The Reformation Justified: In a Sermon Preached at Guild-Hall Chappel Septemb. 21. 1673 before the Lord Major and Alderman (London, 1674); Gilbert Burnet, Rome's Glory and the Mystery of Iniquity (London, 1673); The Mystery of Iniquity Unveiled in a Discourse, Wherein Is Held Forth the Opposition of the Doctrine, Worship, and Practices of the Roman Church; John Tillotson, The Hazard of Being Saved in the Church of Rome (London, 1673). 
apparatus to the audience. In an age of religious division, the study of the past was a helpful tool not only to redefine the present in a sense but also to create sophisticated techniques requisite for an age when rational and scientific discourses gained ground. ${ }^{10}$ Thus, there was a common belief among the latitudinarians that the facts of history would warrant the Anglican Church as a true church.

Anglican divines' study of sixteenth century church history could not be separated from questions about the legitimacy of papal jurisdiction over England. The Anglican historiography of the Reformation was a means of defending the Church of England from Catholic attack. It was the question about the nature of the Reformation that Roman Catholic and Anglicans were widely concerned with as long as both attempted to use the apocalyptic framework to accomplish their rhetorical purposes. The dispute over the legitimation of the Reformation between Catholics and Anglicans could not be pursued without any explanation of church history. Among both sides there was a tacit agreement on demand for the enunciation of which church was a true one God originally designed. The post-Reformation period saw, as Justin Champion has argued, the practice of history legitimating social practices and institutions such as the Church of England. Historians and churchmen were convinced that scholarly research could give sufficient proof about the true model of Church government and discipline. ${ }^{11}$ At the same time, Protestant apologetics were able to connect the prophetic designation of the Reformed Church with the long history of Christianity. For that purpose, Gilbert Burnet, Edward Stillingfleet and others had started looking into religious matters through historiographical lenses from the earliest stage of their literary careers.

The latitudinarians' concern with historical vindication of the Church of England also led to seeking for the implications of apocalyptic interpretations in English history. Political circumstances in the Restoration prompted the application of apocalyptic rhetoric not only to the contemporary events but also to the whole range of ecclesiastical history. Many Englishmen had expounded the meaning of biblical prophecies based on historical events in England and Europe. ${ }^{12}$ This apocalyptic interpretation of history was shown too in works of the latitudinarians.

\footnotetext{
${ }^{10}$ Champion, The Pillars of Priestcraft Shaken: The Church of England and Its Enemies, 1660-1730, 34.

${ }^{11}$ Ibid., 25-6.

12 Johnston, Revelation Restored: The Apocalypse in Later Seventeenth-Century England (Woodbridge: Boydell Press, 2011), 125-32.
} 
Although the latitudinarians' apocalyptic responses to contemporary events in the Restoration was less perspicuous than other Protestant writers whose concerns of scriptural prophecy formed the intellectual landscape of the seventeenth-century apocalyptic ideas, they maintained that history reflected the judgement of God against false Christians.

What these Anglicans heavily concentrated was on vindicating the Reformation as a historically inevitable process under the control of God's providence. The most prominent advocate of the apocalyptic interpretation of the history of the Reformation was Gilbert Burnet. Burnet's History of the Reformation of the Church of England, published first in 1679, mainly aimed to defend the Tudor Reformation and depict this break with Roman Church as the work of divine providence. Burnet's History of the Reformation was written in order to give a more accurate and reasonable account of ecclesiastical history of England than previous authors, especially the Catholic apologist Nicholas Sander.

Burnet thought that the growth of popery was not negligible, as religious quarrels loomed large when it became well known that James had changed his faith. The fact that English Protestants were preoccupied with the popish threat since the late 1670s explains the reason why Burnet's History gained popularity among Anglicans until some critics appeared from the mid-1680s. ${ }^{13}$ Many Anglican divines found themselves engaging in historical and religious controversies with the Catholic polemicists. On 4 April 1676, Burnet and Stillingfleet took part in a conference with some Catholic priests, or Catholic sympathisers, including James Coleman, a Catholic layman. This controversy was caused by a lady who was acquainted with Burnet. She suspected her husband, Sir Philip Terwhit of being a papist and desired to discuss this matter with Burnet and Stillingfleet. Afterwards Burnet published this debate under the title of A Relation of Conference Held about Religion (1676). Even if he thought his adversaries' arrogance came to light in the dispute, he expressed his pity for the lady who had changed her religion. ${ }^{14}$ This conference would have made him gain a reputation as an outstanding clergyman standing in the front line of opposition to popery.

Meanwhile, his acquaintance, the Attorney General Sir William Jones

\footnotetext{
13 Simon Lowth wrote a criticism of Burnet's History, Of the Subject of Church Power (1685) and some letters. See Drabble, 'Gilbert Burnet and the History of the Einglish Reformation: The Historian and His Milieu', 360.

${ }^{14}$ Burnet, Bishop Burnet's History of His Own Time, 1:395.
} 
persuaded him to undertake to write the history of England. Burnet remembered that 'all my friends press me to answer it [Sander's book], by writing the history of the Reformation. So now all my thoughts were turned that way'. ${ }^{15}$ The first volume was published when the popish plot was under investigation, and he won popular acclaim. In 1680 both houses of parliament gave the official approval to it. Two years later the second volume was published during the Exclusion Crisis when many political writings were produced.

The historians that Burnet engaged with in his History were the Protestant propagandist John Foxe, the Laudian clergyman Peter Heylyn and the Roman Catholic apologist Nicholas Sander. Burnet admitted that Foxe's voluminous works also gave an explanation of the Reformation at length, yet he concluded that his historical descriptions were not accurate. For him it was clear that the Reformation was initiated by Henry VIII's actions against the pope. God's hand was at work. For all the king's defects, it was no wonder that God's providence employed the prince 'who had great mixtures of very gross faults', to accomplish what he designed to do. $^{16}$

The biographer of William Laud, Peter Heylyn (1599-1662), received a great deal of publicity for his Ecclesia Restaurata, first printed in 1661. Like other Protestant polemicists, Heylyn reacted to Sander's work in a derogatory manner. Cynically calling Sander 'Dr. Slanders', Heylyn spoke of Sander's 'pestilent and seditious Book, Entitled De Origine et Progressu Schismatic Anglicani, casting doubt on the credibility of the book because of his 'frequent falshoods make him no fit Author to be built upon in any matter of importance. ${ }^{17}$ Anthony Milton has explained at some length, that what Peter was concerned about in Ecclesia Restaurata was to warn of 'the dangers of Calvinist Presbyterianism' by contrasting hostile Calvinism with the moderate spirit of English Protestantism. His depiction of the process of the English Reformation during the Tudor period represented his

\footnotetext{
15 Ibid., 1:396.

16 Burnet, The History of the Reformation of the Church of England, vol. 1 (London, 1679), sig. c2v. For Burnet's historiography of the Reformation, Champion, The Pillars of Priestcraft Shaken: The Church of England and Its Enemies, 1660-1730, 77-98; Drabble, 'Gilbert Burnet and the History of the Einglish Reformation: The Historian and His Milieu', 351-63; Claydon, 'Latitudinarianism and Apocalyptic History in the Worldview of Gilbert Burnet, 1643-1715', 577-97.

${ }^{17}$ Peter Heylyn, Ecclesia Restaurata; or the History of the Reformation of the Church of England (London, 1661), 122; Nicholas Sander, Rise and Growth of the Anglican Schism Published A. D. 1585, trans., David Lewis (London: Burns and Oates, 1877), xxii.
} 
insistence on the religious settlement based upon Laudianism. ${ }^{18}$ Laudianism was central to Peter's religious thought. Right after Ecclesia Restaurata, he went on to write Cyprianius Anglicus, the biography of Archbishop of Canterbury William Laud, published posthumously in 1668. This book provided a 'Necessary Introduction to the Following History', a brief history of the Reformation and religious settlement in the Tudor and early Stuart periods, and the detailed explanation of Laud's life and religious and political views. ${ }^{19}$ The work on the life of the former archbishop reveals that his negative attitude to Calvinism which seemed to be synonymous with enthusiasm and instability highlighted his defence of Laudian-style religious settlement. One significant aspect of Laudianism in his works was his justification of the jure-divino Church of England. In his History of Episcopacy (1657), Heylyn had claimed that the English Church was built upon divine right episcopacy from which the Church could gain authority to teach true practices Christianity and protect the Church from seducing and impious heresy. ${ }^{20}$

At the same time, however, Burnet also felt Heylyn's Ecclesia Restaurata was defective. He saw there were still biased explanations in Heylyn's interpretation of the history of the Reformation. Burnet spoke of Heylyn's work on the history of the Reformation:

Doctor Heylyn wrote smoothly and handsomely, his Method and Stile are good, and his work was generally more read than any thing that had appeared before him: but either he was very ill informed, or very much led by his Passions; and he being wrought on by most violent prejudices against some that were concerned in that time, delivers many things in such a manner and so strangely, that one would think he had been secretly set on to it by those of the Church of Rome, though I doubt not he was a sincere Protestant, but violently carried away by some particular conceits. ${ }^{21}$

Where Burnet did not agree with Heylyn was his argument for the exclusive authority of the priest. It is remarkable to see that they shared a common perception of ecclesiastical history. They believed that Reformation history was part of

\footnotetext{
18 Anthony Milton, Laudian and Royalist Polemic in Seventeenth-Century England: The Career and Writings of Peter Heylyn (Manchester: Manchester University Press, 2007), 202-4.

${ }_{19}$ Heylyn, Cyprianus Anglicanus: Or the History of the Life and Death of the Most Reverend and Renowned Prelate William (London, 1668).

${ }^{20}$ Champion, The Pillars of Priestcraft Shaken: The Church of England and Its Enemies, 1660-1730, 67; Milton, Laudian and Royalist Polemic in Seventeenth-Century England: The Career and Writings of Peter Heylyn, 20711; Starkie, 'Gilbert Burnet's Reformation and the Semantics of Popery', 143.

${ }^{21}$ Burnet, The History of the Reformation of the Church of England, 1, sig. b1v.
} 
revelation of divine providence. Both agreed that the English Church was true religion which divine providence brought to the earth. However, there was disagreement in the evaluation of the Reformation and the nature of true religion between these two Anglicans. Heylyn's pro-clericalism and antipathy to continental Calvinists' influence in the Edwardian period attracted some Catholic writers who diminished Protestant apologetics. ${ }^{22}$ As many historians have argued, Heylyn's insistence on the independence of authority of the priests was in marked contrast to Burnet's views. Heylyn's interpretation of church history was later echoed by the non-juror Jeremy Collier who published an Ecclesiastical History of Great Britain in $1714 .^{23}$ Burnet became involved in the historical controversy with nonjurors until his death.

Burnet's principal target was the Catholic priest Nicholas Sander (c.15301581). Sander's posthumous Latin book, De Origine et Progressu Schismatic Anglicani published in 1585 was translated into French in 1676. Sander's study of the history of the reformation aimed to undermine the Protestant understanding of the English Reformation that had justified its separation from the false Catholic Church. Sander's labelling the Church of England with schism was a pivotal point in his derogation of the English Reformation. For him, the English Reformation was nothing but a product of human cupidity. In short, Sander believed that the Reformation was motivated by Henry VIII's personal greed. In the preface to the History of the Reformation, Burnet was outraged by Sander's attack on the English Church. Burnet stated that Sander's narrative contained many errors which were disproved and his historical study was 'quoted with much assurance' by many writers in the Roman Church. ${ }^{24}$ According to him, Sander's history called the legitimacy of the Church of England into question since it was began 'by the lusts and passions of King Henry the Eighth, carried on by the Ravenousness of the Duke of Summerset, under Edward the Sixth, and confirmed by the Policy of Queen Elizabeth and her Council to secure her Title. ${ }^{25}$ Burnet was worried by the translation of Sander's book being spread abroad, especially in France. He complained that Englishmen had

\footnotetext{
${ }^{22}$ Milton, Laudian and Royalist Polemic in Seventeenth-Century England: The Career and Writings of Peter Heylyn, 215.

${ }^{23}$ See Starkie, 'Contested Histories of the English Church: Gilbert Burnet and Jeremy Collier', in The Uses of History in Early Modern England, ed., Paulina Kewes (San Marino, California: Huntington Library, 2006), 32946; Champion, The Pillars of Priestcraft Shaken: The Church of England and Its Enemies, 1660-1730, 91.

${ }^{24}$ Burnet, The History of the Reformation of the Church of England, 1, sig. b1v.

25 Ibid., sig. b2r.
} 
not enjoyed historical defences of their Protestant Reformation, while several Roman Catholic countries had the benefit of their own partisan historians. ${ }^{26}$ This prompted him to provide a fuller and better account of the English Reformation than Sander had given.

In his defence against Sander's charge of schism, the main argument in History of the Reformation was based upon a sense that human history showed divine providence at work. Burnet assured that there was God's manipulation of the princes behind the Reformation which was brought to the world by means of human hands like Henry VIII. Burnet acknowledged that there was 'a signal providence of God, in raising up a King of his temper, for clearing the way to that blessed Work.' In his description of the first phase of the Reformation, the king was metaphorically 'the Postilion of Reformation' in the light of his deeds for Protestantism. ${ }^{27}$

Burnet suggested that the Henrician Reformation contributed to two significant things: the translation of the Bible into English, and the establishment of the Church of England as a national church. Facing accusations that Henry VIII's religious policy was cruel and impure, Burnet answered that the monarch was not without fault. However it was important for him to note that the prince was designed by God to play a leading role in the eradication of errors and corruptions in the Roman Church. For all Henry's faults, Burnet asserted that the employment of the prince who 'had great mixtures of very gross faults' was not unusual in the way in which divine providence had accomplished its purpose. ${ }^{28}$ Burnet thought there had been many historical examples of God's use of princes whose defects in their lives had been condemned: David, Solomon, Cyrus, Constantine, and so on. Speaking of Jehu, the king of Israel, Burnet observed that

Jehu did an acceptable Service to God, in destroying the Idolatry of Baal, though neither the way of doing it be to be imitated, being grosly insincere, nor was the Reformation compleat, since the Worshipping the two Calves was still kept up; and it is very like, his chief design in it, was to destroy all the Party that favoured Ahab's Family; yet the thing was good and was rewarded by God. ${ }^{29}$

These examples led to the argument that God's providence compensated in some way

\footnotetext{
${ }^{26}$ Ibid., sig. b1r.

${ }^{27}$ Ibid., sig. c1v.

${ }^{28}$ Ibid., sig. c2v.

29 Ibid., sig. d1r.
} 
for the deficiencies of human beings when it came to building up true religion.

Burnet understood the setting up of true religion as a gradual process. The progress of the Reformation was described with the support of magisterial authority. There were some significant phases in the history of the Reformation during the Tudor period. According to Burnet, those who suffered in the time of popish cruelty and persecution but had kept innocent tempers and pious lives and Henry VIII's struggle with the Pope paved the way for the first change. There was no doubt, he said, that 'the Reformation went on with so little Tumult and Precipitation in King Edward's time'. ${ }^{30}$ However, the calm and moderate progress made under Edward VI was suddenly thrown into reverse and chaos when the Catholic Queen Mary came to the throne: 'Popery did more plainly discover itself in the many repeated Burnings, and the other Cruelties then openly exercised.' Burnet viewed the nation under the reign of Mary was in huge danger. Again, the situation was dramatically changed. After Elizabeth's succession, 'such great Alterations were so easily brought about in so short a time ... and this Church has since that time continued to be the Santuary and shelter of all Forreigners, and the chief of Object of the Envy and Hatred of the Popish church, and the great Glory of the Reformation'. ${ }^{31}$

The gradual reform of the Church of England during the Tudor period provided an answer to the Catholic allegation that the Reformation 'was like to change as oft as the Fashion did'. It was no doubt, Burnet argued, that 'the corruptions which they had been introducing for above a thousand years, were not all discovered or thrown out at once; but now the business was brought to a fuller perfection', so it was inevitable to think that there would be more changes. ${ }^{32}$

How the English monarchs in cooperation with parliament and clergy carried out the reform of false religion was described in detail in his narration. Burnet frequently laid weight on parliamentary actions for the Reformation. ${ }^{33}$ In this religious movement, Burnet claimed that Parliament played an important role in securing the effect of the Henrician Reformation in favour of the English Protestants. He believed that Henry VIII's supremacy over the church was a great part of the success of the Reformation, but he did not forget that his authority was confirmed by

\footnotetext{
30 Ibid., sig. d1v.

${ }^{31}$ Ibid., sig. d2r.

32 Ibid., 1:190.

${ }^{33}$ See, Starkie, 'Gilbert Burnet's Reformation and the Semantics of Popery', 146-47.
} 
Parliament. In fact, it should be said that the king achieved the Reformation in cooperation with Parliament. The Reformation Parliament (1529-1536) passed reform statutes; sanctioned the translation of the Bible, and abolished monasteries. ${ }^{34}$ Apart from monarchical despotism, Burnet made it clear that the sovereignty of the monarch was based upon the 'king-in-Parliament' not upon the absolute monarchy. His view of the nature of legislative power implied that the English Reformation was not invoked by a mere personal desire but by the assent of the majority of English people whom Parliament represented. ${ }^{35}$

Along with parliamentary participation in achieving a Reformation through legislation, Burnet also emphasized Archbishop Cranmer's role in the gradual progress of the Reformation. According to Burnet, one of Cranmer's contributions was the dissolution of the monasteries. Cranmer found that the foundation of monasteries was 'inconsistent with a full and true Reformation' and their abuses such as doctrines of 'purgatory' and 'the worship of Saints and images' were necessary to be reformed. As Burnet stressed that practices, institutions, and doctrines were corrupted before the Reformation, Cranmer's scheme seemed to be worthy of praise to him. Burnet alluded to an extract of a visitation held in 1535 from which he assumed that there had been idolatry and superstition in many monasteries and the 'Lewdness of the Confessors of Nunneries', and 'the dissoluteness of Abbots and the other Monks and Friars' were comparable to 'any that were in Sodom'. ${ }^{36}$ Burnet praised Cranmer's continuous effort to maintain reform during the reigns of first two Tudor monarchs by illustrating that all men 'looked on him as one raised by God for most extraordinary ends'. 37

Burnet's history of the English Reformation suggested that not all Tudor monarchs promoted the Reformation movement. For him the progress of the movement varied according to the religious inclinations of different monarchs. Catholic conspiracy to bring Catholicism back to the country and the persecution of the Protestants seemed to him to be indicative of the dark period of Reformation history. The stories of many Protestants who were persecuted at the instigation of some bishops like Edmund Bonner and Stephen Gardiner under Henry VIII and

\footnotetext{
${ }^{34}$ Michael A. R. Graves, Early Tudor Parliaments, 1485-1558 (London: Longman, 1990), 79; Peter Marshall, Religious Identities in Henry VIII's England (Aldershot: Ashgate, 2006), 63-4.

35 Burnet, The History of the Reformation of the Church of England, 1:143; 2:89, 95, 193, 197.

36 Ibid., 1:190-91.

37 Ibid., 2:226.
} 
Mary formed a considerable part of the work. Protestant priests who were persecuted for their beliefs such as Robert Barnes, Thomas Gerrard, and William Jerome had been treated as martyrs since John Fox recounted them in his Acts and Monuments. ${ }^{38}$ Burnet presented dissatisfaction with the situation surrounding the Reformation by the 1540s. The growth of popery was visible to him. Burnet lamented that the short period of Edward VI's reign led to the return of papal policies under Queen Mary. On the one hand, Burnet described,

Gardiner and all that Party, were for bringing Religion back to what it had been at King Henry's Death; and afterward, by slow degrees, to raise it up to what it had been before his breach with the Papacy. On the other hand, the Queen, of her own Inclination, was much disposed to return immediately to the Union of the Catholick Church, as she called it. ${ }^{39}$

Bishop Gardiner was described as a papist clergyman who was committed to Mary's oppressive religious policies. Burnet made it clear that Catholic sympathisers like Gardiner cooperated with Mary in persecuting Protestants. Burnet spent many pages in depicting how Marian martyrs underwent persecution fuelled by Gardiner and Mary. ${ }^{40}$ Burnet understandably regarded the Marian period as a huge step backwards that revealed the popish party's power growing again over England and beginning to re-establish idolatrous and superstitious practices with old rites in the Church. ${ }^{41}$ In addition to clerical corruption, Burnet claimed that Parliament also went astray. In many places across England,

Men were chosen by Force and Threats: in other places those imployed by the Court, did by violence hinder the Commons from coming to chuse; in many places false Returns were made; and that some were violently turned out of the House of Commons ... it was no Parliament, since it was under a Force: so might be annulled as the Parliament held at Coventry in the 38th year of King Henry the 6th was, upon Evidence of the like Force, declared afterwards to be no Parliament. ${ }^{42}$

On this account, Gardiner, along with the rest of the popish clergy, was a pawn of Antichrist who seduced the monarch into error, idolatry, and persecution.

\footnotetext{
38 Susannah Brietz Monta, Martyrdom and Literature in Early Modern England (Cambridge: Cambridge University Press, 2009), 1-3.

${ }^{39}$ Burnet, The History of the Reformation of the Church of England, 2:242.

${ }^{40}$ Ibid., 2:246, 295, 299-301.

${ }^{41}$ Ibid., 2:247.

42 Ibid., 2:252.
} 
When Burnet contemplated the reason for this it was obvious that God's temporary wrath was unleashed upon England. 'The sins of England', Burnet wrote, 'did at this time call down from Heaven heavy Curses on the Land'. ${ }^{43}$ Burnet thought that any denial of the Reformation would bring divine wrath and punishment.

From Burnet's point of view, martyrs were the result of divine providence which allowed papists to commence persecution against Cranmer and others. Burnet, like other Protestant writers, reminded his readers that the true church had always suffered from severe persecution. The tradition of martyrology was a strong weapon for the Protestant Church to compare itself with the apostolic Church. Foxe and Bale were regarded as prominent forerunners of Protestant martyrology in the seventeenth century. Foxe's historical narration of the Protestant martyrs provided apocalyptic proof that the English Church had been blessed as a true church. ${ }^{44}$ Burnet shared this idea with Foxe and thus assured himself that paradoxically divine providence was at work in the persecution of the Protestant Church.

However, the providential cycle of history soon replaced Mary's brutal treatment of Protestantism with the Elizabethan settlement. 'All those Fires', he wrote, 'did not extinguish the Light of the Reformation, nor abate the love of it' ${ }^{45}$ Burnet's narration of the reign of Elizabeth showed the continuation of the Reformation. He stressed that the Reformation was restored by Parliament in both England and Scotland while the reformed divines endeavoured to serve the monarch for the completion of the Reformation.

This understanding of the Reformation for Burnet relied on the realisation that the Reformation was not simply a critical moment but also a long-term process of history when the true church had been defeating the false church. As Claydon suggests, 'Burnet's keen sense of the apocalyptic struggle between the false and true churches' was accepted by early Protestant authors in England and was crucial to their understanding of how the true church has been revived. ${ }^{46}$ In this context the churches could be easily labelled with providential language: Catholicism was held to be the false or idolatrous church while the Reformed church represented the biblical image of the church.

\footnotetext{
43 Ibid., 2:227.

44 A. G. Dickens and John Tonkin, eds., The Reformation in Historical Thought (Oxford: Blackwell, 1985), 40-7.

${ }^{45}$ Burnet, The History of the Reformation of the Church of England, 2:338.

${ }^{46}$ Claydon, 'Latitudinarianism and Apocalyptic History in the Worldview of Gilbert Burnet, 1643-1715', 588.
} 
On the other hand, Burnet's idea of the gradual progress of the Reformation made him believe that the reform of the Church of England was unfinished. It still seemed to him that 'Wrath of God hangs over our heads, and is ready to break out upon us,. ${ }^{47}$ He thought that the reformed church was still in danger even though divine providence had led the true church against antichrist. A sense of unfinished reform enabled him to insist on the further need for the restoration of the virtues of the early Church.

Other latitudinarians were concerned with apocalyptic disclosure of the victory of God over erroneous adversaries. Armed with an apocalyptic view of history, they set forth the idea of the continuity of providential history. Edward Stillingfleet shared a similar framework in his application of apocalyptic idea to political events. For him the continuous intervention of divine providence could be witnessed from the Reformation. Not long after the Restoration, he thought he read divine providence at work in history. In his Rational Account of the Grounds of Protestant Religion (1665), Stillingfleet expressed his delight in the exercise of God's providence in England. He believed that divine desire for the reform of the church is ongoing in spite of the conspiracies of the opposing power. Since the 'great miracle of Divine Providence in your majesties most happy restauration', Stillingfleet said he had seen 'those who before triumphed over the Church of England, as much expressing their envy at her resurrection' ${ }^{48}$

Simon Patrick also acknowledged that the righteous providence of God remained unchanged despite the depravity of human beings. He assured readers that God promised the people that he would preserve them by his providence. Patrick was strongly confident that every event was controlled by divine providence so he thought that all the people could do was to 'put our selves into the hands of God'. The central notion to his view of divine providence was the conviction that human beings must rely upon providence. Thus Patrick went on to observe that 'if we be not saved from the destroying Angels, there was great reason that we should die'. ${ }^{4}$ For him the English Restoration was an obvious proof of the revelation of the apocalypse in history: England enjoyed Charles II's happy restoration after the political tumult of

\footnotetext{
47 Burnet, The History of the Reformation of the Church of England, 2, sig. e2r.

${ }^{48}$ Stillingfleet, A Rational Account of the Grounds of Protestant Religion Being a Vindication of the Lord Archbishop of Canterbury's Relation of a Conference (London, 1665), sig. a3r.

49 Simon Patrick, Consolatory Discourse, Perswading to a Chearfull Trust in God in These Times of Trouble and Danger (London, 1665), 12.
} 
Civil War, Republicanism and military dictatorship. However, Patrick's view of history relied on the fear that the judgment of God would be visited on his people for their impiety. In parallel with the biblical story that God gave his word to the Israelites in the days of the prophet Isaiah to verify his providential scheme in Israel, Patrick wrote that 'we that in former Days were the Admiration, if not the Envy, of our Neighbours for the Happiness we enjoyed, became not long ago, an Astonishment, a Prover, and a Byword, by reason of the many, very many and sore Calamities, which fell upon us'. ${ }^{50}$ Patrick's interpretation of history showed both triumph and disaster in human society until the final judgment of God.

\subsection{Anglican Primitivism against Roman Gentilism}

The close alleged relationship between the Church of England and the Primitive or Early Christian Church was central to the latitudinarian outlook. In common with many other Anglicans they saw the English Reformation as a re-assertion of the Church of England's 'primitivism' in contrast to the Church of Rome's 'superstition'.

Their understanding of the Primitive Church was framed within an historical and apocalyptic notion of the 'true church'. The concept of a true church was understood within the Protestant apocalyptic worldview which assumed the final victory of the true Protestant church over false deceivers on a cosmic scale. The Church of England readily traced its authoritative form of church government from the Early Church church and compared its practices and doctrines with those of the primitive Christians. While English Protestants strongly held that the Church of Rome was false religion due to its antichristian characteristics, the Church of England had in turn faced the question from Roman Catholics, 'where was your church before the Reformation?' Despite the Anglican appeal to the history of the Reformation for the justification of the Protestant break from Catholicism, there was a demand for the further explication of any ecclesiastical relation between the Anglican Church and the primitive church. Therefore, historical continuity between the Reformed Church and the primitive church was essential to Anglican apologetics. $^{51}$

The Anglican legitimation of the Reformation heavily relied upon a belief

\footnotetext{
${ }^{50}$ Ibid., 16.

51 Spurr, “"A Special Kindness for Dead Bishops": The Church, History, and Testimony in Seventeenth-Century Protestantism', 397-98.
} 
that the Church of England inherited its doctrines from the primitive church. The latitudinarians had no doubt that history evinced the spiritual connection of the Church of England with the first centuries of ancient Christianity in spite of the intervening superstitious and tyrannical centuries when papal authority dominated Europe. It was of importance for them to demonstrate that the Reformed Church inherited its theological and pastoral virtues from the primitive church.

The latitudinarians built upon a foundation of earlier and wider historical work among English Protestant scholars. As the previous chapter has shown, sixteenth- and early seventeenth-century English writers like Foxe and Bale provided the main structure of the Protestant historiography of the political events of the Reformation. Foxe's synchronisation of English history with the apocalyptic scenario illustrated the Reformation of the Church of England as a momentous moment in providential history. ${ }^{52}$ While these predecessors developed an Anglican historiography aligned to an apocalyptic interpretation of history, writings by sixteenth-century scholars also stressed the primitivism of the reformed Church. ${ }^{53}$

Seventeenth-century England saw an abundance of historical explanations in works on theology and politics. Many works aimed to undermine the Catholic claim of the apostolic succession back to St Peter through the line of bishops. It was common for Protestant clergy to hope that historical study would reveal that the Pope and the Catholic Church were Antichrist and that papal claims to apostolic authority (and hence a claim to exclusive power over other churches and over civil magistrates) were based upon false evidence. ${ }^{54}$ Protestant historiography also attempted to show that the Reformed Church shared admirable spiritual characteristics with the Early Church in the age of the Fathers.

The apocalyptic historical demonstration of the connection between the Church of England and primitive church was evident in the work of Henry More, a close associate of the latitudinarian divines. More wrote an apocalyptic interpretation of church history in the 1660s with the aim of showing that the history of the Church of England was evidence of God's providential care for a true church. More's

\footnotetext{
52 Avihu Zakai, 'Reformation, History, and Eschatology in English Protestantism', History and Theory 26, no. 3 (1987): 310.

${ }^{53}$ For the use of the primitivism of the church in the Church of England from the sixteenth century, see David Manning, "That Is Best, Which Was First": Christian Primitivism and the Reformation Church of England, 15481722', Reformation \& Renaissance Review 13, no. 2 (2011): 153-93.

54 Zakai, 'Reformation, History, and Eschatology in English Protestantism', 305.
} 
calculation of the apocalyptic history of Christianity provided a picture of how long the godly had suffered religious persecution and the church had been corrupted by Antichrist throughout providential history. First of all, More was convinced that the primitive church was pious and pure in practices and doctrines but the church became depraved after A.D. 432, the year of Constantine's conversion to Christianity. One of the biblical images most important to More's exegesis was St. John's vision of seven churches in Rev. 2-3. He described the epistles to the seven churches in the Book of Revelation as referring to different historical stages: 'Ephesus, till Anno Christi 110; Smyrna, till 306; Pergamus, declining towards Popery, ... about Anno 1160; Thyatira, emerging from Popery, till the Pacification at Passau in Germany 1552; Sardis at King Edward VI's reformation in England; Philadelphia, when Truth, Peace and Holiness shall universally prevail ... and lastly, Laodicea, when towards the end of the Thousand years Satan shall be again let loose a little space'. ${ }^{55}$ In his prophetical interpretation, seven churches represented each historical phase of the church in the course of realization of God's providence: the church of Ephesus and Smyrna represented the primitive church and the church of Pergamum and Thyatira implied the interval between A.D. 324 and 1552, during years when medieval church had deviated from the original spirit of Christianity; the following two churches, Sardis and Philadelphia, the Reformation, the last Laodicea church depicted the true church to come in the future. ${ }^{56}$ This prophetical division of periods by means of the apocalyptic image of seven churches was based upon assumption that the church had not been antichristian but this 'ancient symmetral church' lost its original virtues and was corrupted by heretical practices 120 years after the conversion of Constantine. Calculating the period of antichrist's control of the church, like others, More estimated that the period of antichristian reign over the church would end in $1692 .{ }^{57}$ After the antichristian period, for him, the reformed church would strike down the antichristian power, the 'Roman Hierarchy'. ${ }^{58} \mathrm{He}$ had no doubt that the Church of England was the true and reformed church because it had kept the 'patterns of the ancient apostolic church' which was infallible in main points. ${ }^{59}$

\footnotetext{
55 Henry More, An Exposition of the Seven Epistles to the Seven Churches Together with a Brief Discourse of Idolatry (London, 1669), sig. a2r-a2v.

${ }_{56}$ Ibid., sig. a2r, a8r, 56, 60-1, 123, 140-57.

57 More, Synopsis Prophetica; or, the Second Part of the Enquiry into the Mystery of Iniquity, 365.

58 More, Apocalypsis Apocalypseos; or the Revelation of St John the Divine Unveiled, 108-9.

59 More, Paralipomena Prophetica: Containing Several Supplemenss and Defences of Dr H. More (London,
} 
More believed that his analysis of prophetical images was conducted in a reasonable way. He attempted to place his methodological approach within the rational understanding of Christian religion and church history. In response to radicals' extreme interpretation of the apocalypse and to the Catholic charge that the Church of England was 'schismatic', he associated a study of mystical prophecies with his commitment to rational way of understanding religion. His apocalyptic historiography could be a weapon to defend the Protestant justification for the Reformation as well as to attack practices and doctrines in the Catholic Church as false inventions. More's identification of some apocalyptic images with historical events provides a comprehensive example of the apocalyptic ideas pervasive in the Restoration. ${ }^{60}$ His explanation was an attempt to combine the reasonable understanding of the history of the church and the traditional interpretation of mystical revelation.

More's historicist exposition is likely to have influenced the younger generation of moderate Anglican thinkers. As the previous chapter shows, there has been scholarly agreement that the key ideas of Cambridge Platonists infiltrated the theology of the moderate Anglican divines. More, one of the Cambridge Platonists, and the latitudinarians had common ground in matters of doctrine and ecclesiology defended through reasonable apologetic. In their rejection of enthusiastic radicalism and dogmatic theology, the moderate churchmen, Burnet, Stillingfleet, Tillotson, and Patrick, all owed a huge debt to this intellectual group at Cambridge. In their view, for example, the confidence in human reason and its power was based upon their faith in the 'goodness' of God's will which was understood as the 'end' of divine providence. ${ }^{61}$ The ending of Christianity, More believed, was the reign of Christ 'with equity, goodness, and sweetness' which human would experience instead of grief. In this sense, Burnet's prophetical exposition was not different from More's apocalyptic interpretation in fundamental points. In his History of His Own Time, Burnet openly acknowledged the debt that he owed to the Cambridge Platonists and their followers. He recalled how, after meeting Benjamin Whichcote, John Wilkins,

\footnotetext{
1685), xi-xiii.

60 Johnston, Revelation Restored: The Apocalypse in Later Seventeenth-Century England, 29-30.

61 Robert Crocker, 'Henry More and the Restoration', Parergon: Australian and New Zealand Association for Medieval and Early Modern Studies 21, no. 2 (2004): 132, 40; W. M. Spellman, The Latitudinarians and the Church of England, 1660-1700 (Athens, Georgia: University of Georgia Press, 1993), 24-5, 27-9, 88. For other Anglicans' note of More's influence, see Johnston, Revelation Restored: The Apocalypse in Later SeventeenthCentury England, 226-28.
} 
Henry More, other latitude-men on his first visit to England in 1663, 'I easily went into the notions of the Latitudinarians' ${ }^{62}$

More's works demonstrated the importance of historical interpretation in the anti-popery dispute during the Restoration. As the previous chapter shows, the language employed in his apocalyptic understanding of church history was used to reject the authority of Roman church. Facing Catholics' accusation of an erroneous institution against the Church of England with the rejection of the validity of the Reformation, Gilbert Burnet declared, in The Mystery of Iniquity unveiled (1673), that it was popes and General Councils that had erred in religious matters, and that had been anathematized as heretics. By doing so, they made the vulgar people blind to false faith, and then, consequently, exposed them to the greatest danger. ${ }^{63} \mathrm{He}$ enumerated Catholic practices which were, for him, in remarkable contrast to the values brought to this world by the blood of Christ. This distraction of the laity from 'the spirit of Christianity' was evidence enough to show that Catholicism was the corrupted institution. ${ }^{64}$ In challenging Catholic tradition, Burnet saw the present doctrines in the Catholic Church as changed during the first few centuries of Christianity. For example, he argued that the Fathers magnified the Sacrament but when they did so, they did not believe 'corporal presence,' unlike the Roman Church of his time which firmly had believed transubstantiation. In his eyes there must had been a distortion in the nature of Christianity 'through the ignorance of some ages' when there little historical evidences written remained. ${ }^{65}$ In other work, Burnet stated that the fall of the Roman Empire and massive invasions of Germanic tribes caused the demolition of 'learning and civility' and thus brought 'a Night of Ignorance'. ${ }^{66}$ On this account, he claimed that the primitive characteristics of apostles were forgotten during superstition and idolatry grew up in the church.

When it came to the historical justification of the Church of England, it was necessary to demonstrate how the pope and the Roman institution became corrupted before the Reformation. As discussed in the preceding chapter, Gilbert Burnet

\footnotetext{
${ }^{62}$ T. E. S. Clarke and H. C. Foxcroft, eds., A Life of Gilbert Burnet, Bishop of Salisbury (Cambridge: Cambridge University Press, 1907), 38; Martin Greig, 'Gilbert Burnet (1643-1715)' in Oxford Dictionary of National Biography (2004).

${ }^{63}$ Burnet, The Mystery of Iniquity Unveiled in a Discourse, Wherein Is Held Forth the Opposition of the Doctrine, Worship, and Practices of the Roman Church, 48.

${ }^{64}$ Ibid., $49-58$.

65 Ibid., 120-21.

${ }^{66}$ Burnet, A Relation of the Death of the Primitive Persecuters, 33.
} 
ascribed corruption to papal avarice and to the incorporation of 'idolatrous' pagan practices into the Roman Church. Burnet argued that this 'Heathenism' or, in his phrase, 'Gentilism' had diverted the church from the true path. It was therefore necessary to reject all inventions in the worship of God which were contrary to reasona, and to retain the simplicity of worship 'without any mixtures drawn from Judaism or Gentilism'. ${ }^{67}$ The main points he blamed for 'Gentilism' related to the manner of worship. Burnet wrote that the heathens had traditionally worshipped some statues or creatures in which they believed God to be present, and that the church held this heathenish idea 'the greatest piece of her religion to adore the bread with the same devotion' so that they conceived Christ as being 'visibly present' ${ }^{68}$ In the narration of pagan rites, Burnet gave another example about worshipping other creatures beside God. This kind of idolatry, for him, could be traced back to Babylon where the statue of Belus - the father of Ninus, the Assyrian king - was set up by his command, and was worshipped. After the conversion of the Roman Empire, the worship of others was transformed into that of 'angels and saints in the Roman Church' in order to 'gain the pagan world through compliance with Christianity'. Instead of their gods, therefore, he thought, the church set out to accommodate these pagan and 'Baal-worship' to the adoration of the Apostles and other Saints and martyrs, and the Catholic Church had afterwards kept worshipped them and appointed saints for every nation: 'St. Andrew for Scotland, St. George for England, St. Patrick for Ireland, and any other saints for other nations' ${ }^{69}$ Having looked into history, Burnet was convinced that the pagan residues continuously remained unreformed in the Roman Church.

Edward Stillingfleet offered a similar interpretation. The process in which the church degenerated into error was understood as the invasion of pagan customs. Not long after the primitive fathers such as Clement of Alexandria and Origen inveighed against the 'Heathen Idol', Stillingfleet thought, the pagan style of worship of images sneaked up on the medieval church via the general councils, although some bishops had condemned these councils for asserting superstition. ${ }^{70}$ In his historical understanding, it is remarkable that Stillingfleet also took note of 'Heathenism' or

\footnotetext{
${ }^{67}$ Burnet, The Mystery of Iniquity Unveiled in a Discourse, Wherein Is Held Forth the Opposition of the Doctrine, Worship, and Practices of the Roman Church, 150.

${ }^{68}$ Ibid., 22-3.

${ }^{69}$ Ibid., 24-5.

70 Stillingfleet, A Discourse Concerning the Idolatry Practised in the Church of Rome, 69-70, 89.
} 
'Paganism' like Burnet did. But 'Heathenism' was quite a comprehensive term for both authors. Borrowing the words of Archbishop Laud, he argued that the idolatry forbidden in the Scriptures had been used by the Jews or Pagans; the ancient church did not accept the worship of image while the Church of Rome in the modern age succumbed to Paganism in the practice of religious ceremonies. ${ }^{71}$ For him all kind of worship of images in Catholic Church matched all the idolatries of the pagans and many Protestants charged Rome with preserving these superstitions. Thus Stillingfleet concluded that people could not find salvation in the Catholic Church because of the church being guilty of 'Hypocrisies' or 'Idolatry' which were incompatible with faith and virtues essential for the true church to claim eternal salvation. $^{72}$

In contrast to their disclosure of lingering paganisation in the Roman Church, latitudinarians regarded the Protestant Church as maintaining the pure, primitive, and apostolic faith. For them it was certain that the Reformation was the restoration of virtues which ancient Christianity had been thought to retain. Hence they endeavoured to explain that the Church of England kept seeking for and preserving these apostolic inheritances. In the second chapter of his Rational Account of the Grounds of Protestant Religion, Stillingfleet claimed that the separation of the Reformed Church from Rome would have been avoided if the Church of Rome had had the 'Piety' and 'Devotion' of the primitive church. 'The ambition and usurpation of the Church of Rome' introduced superstition and idolatry 'into the publick exercise of Devotion'. ${ }^{73}$ Burnet convinced the readers that 'here we have the Rules of holy Obedience, and the Methods of Repentance and Reconciliation for past sins clearly set before us: we believe all that Doctrin which Christ and his Apostles delivered, and the Primitive Church received'. ${ }^{74} \mathrm{He}$ was convinced that God's providence intended the true church to regain its primitive piety. However, more significantly, in Burnet's interpretation, the anti-Catholic tone in historical explanation was deliberately tied to the apocalyptic vision of the world: antichrist would be defeated by Christ, and the design of Christianity would be perfectly accomplished through the true church, the Church of England. He thought that the

\footnotetext{
${ }^{71}$ Ibid., sig. a7v-a8r.

72 Ibid., 2-3.

73 Stillingfleet, A Rational Account of the Grounds of Protestant Religion Being a Vindication of the Lord Archbishop of Canterbury's Relation of a Conference, 102.

${ }^{74}$ Burnet, The History of the Reformation of the Church of England, 2, sig. e1v.
} 
difference of the doctrines and practices between the Church of Rome and the Church of England was caused by the Church of Rome departing from 'the truth and simplicity of the Gospel in many points'. ${ }^{75}$ Thus the historical narration began with the deviation of Catholic Church from its primitive origin.

Burnet's study of Christian history also reflected the true and original characteristics of Christianity as opposed to those of the Roman Church. The first characteristic he set forth was that God's Word was made accessible to all human beings. ${ }^{76}$ The second characteristic was the perspicuity or simplicity of Christianity. Burnet argued that there was no secret doctrine kept out of the reach of the laity's understanding. ${ }^{77}$ Thirdly, he wrote that Christianity was 'rational and suitable to our souls'. He believed that human reason itself could discover the core principles of Christian faith required to gain salvation, although he admitted the existence of the mysteries of God and Christ which were 'exalted above the reach of our faculties'. ${ }^{78}$ Burnet associated these characteristics with the four ends of Christian religion: giving right apprehensions of the nature and attributes of God, providing the way to reconcile the men with his maker, teaching the perfect and clear divine rules for the perfection of men's souls, and uniting mankind in the close bond of peace, friendship, and charity. ${ }^{79}$ His historical view strengthened an idea that the Protestant Christians ought to go back to recover the faithful and pure life of primitive Christianity in order not to commit to the sin of idolatry with which Roman Church was charged.

This emphasis on the restoration of religious values as a revival of primitive Christianity was powerful rhetoric to justify that the Church of England was a true church designed by God. In Burnet's work, the designs of the Church of England inherited the faithful characteristics from the primitive church. He addressed four main characteristics of Christian religion distinguished from other religions. The first is, its 'verity'. He argued that the truth of Christianity 'appeared visibly in the person of Jesus Christ, who wrought a number of miracles in sight of the Jews and delivered the God's words into the world, resurrected from the dead and declared to be the son of God which was received and believed by mankind though it was contrary to all the

\footnotetext{
75 Ibid., 104-5.

76 Burnet, The Mystery of Iniquity Unveiled in a Discourse, Wherein Is Held Forth the Opposition of the Doctrine, Worship, and Practices of the Roman Church, 116.

${ }^{77}$ Ibid., 131.

78 Ibid., 133-34

79 Ibid., 4-8.
} 
interests of the flesh'. The second was its 'genuine simplicity and perspicuity'. By this he meant that 'all its Doctrines and Rules are clearly and distinctly held out to us, not like Heathen Divinity'. He asserted that Christian doctrines were to be clarified so that people would easily see the substance of truth. The third was 'the reasonableness' which was in a remarkable contrast to absurd and incredible things among pagans and Jews. Through this virtue, he thought that 'Christian religion are fitted for Mankind, and so congenial to his Nature, that they well deserve the designation of reasonable service, or rational worship, God having made us our Souls and them of a piece'. The fourth was its 'easiness' with which the believers were 'freed from all the barbarous and cruel Rites of Gentilism, and from the oppressive Bondage of Judaism, which was a Law of Ordinances, and a yoke that our fathers were not able to bear'. ${ }^{80}$ He claimed that these characteristics needed to be a criteria for discerning true religion.

Therefore for him the English church had taught the people to study the Scriptures and exhorted them to found their faith on God. Many Anglicans argued that the English Church had retained all the virtues in early Christianity, or if not, it had striven to gain them in various ways. With the authority of the Scriptures, he thought, neither irrational nor unconceivable doctrines but religious principles persuasive to the people with rational faculty had been taught. The Anglican writers were content with the evocation of several traits of ancient Christianity: verity, simplicity, purity, charity, and others. The perception that the Church of England succeeded the spirit of the primitive church by promulgating a faith in the link between the Church of England and early Christianity was a strong reason why there is no rational ground for justifying 'a separation from our Church', or 'turning over from us to the Communion of Rome'. ${ }^{81}$ In the latitudinarians' explication of the nature of true religion, certain primitive virtues seemed to be more relevant to their own times and pastoral priorities. Burnet claimed that Anglican clergymen who complied with the discipline of the primitive church were bound to teach the people the pure Word of God and to administer the Sacraments and perform all other holy Functions according to the Scripture; the practice of the Primitive Church, and the rules of Expediency and Reason; and this they

80 Ibid., 9-11.

81 Ibid., 160. 
ought to have done through the Civil Powers had opposed it. ${ }^{82}$

Some clergy argued that the Church of England needed to follow not only recommended virtues of the primitive church but also accept its principles and practices. John Sharp described the church of Ephesus as retaining the truth of Christian doctrine 'in opposition to Heresies of those times'. He continued to argue that 'Our Church may vie with all the Churches in the world, for Orthodoxy and Conformity to the Primitive Church in matters of Faith'. ${ }^{83}$ Therefore, Sharp hoped the Church of England to keep up the form of primitive godliness.

\subsection{Primitive Virtues and Rationality}

It is noteworthy that More, Burnet, Stillingfleet and others laid claim to primitive and apostolic virtues in connection with their theological discipline known as 'rational theology'. Many Anglican agreed that the rational vindication of the Church of England was the one of central tasks. They attempted to get the upper hand in the defence of rationality of Christianity. The Church of England had to defend itself from two adversaries. One attack on the Church of England was the Nonconformists' insistence that the Church was 'halfly reformed', or even had continuities with the Roman Church. Nonconformists urged further reform to transform the Church to the model of the 'wholly reformed' church like the continental Protestant churches. ${ }^{84}$ The other criticism came from Catholic polemicists. They charged the Church of England with the sin of 'schism' or unjustified separation from the true Church of Christ. The Roman apologists regarded the Church of England as being grounded upon false doctrines. They insisted on the proposition that a saving faith was only gained by means of the Scriptures interpreted with the aid of the Roman Church's 'Tradition' of teaching and practice. ${ }^{85}$

The 'reasonable' case for the Church of England was developed in historical terms and as part of the on-going 'rule of faith' controversy with Roman Catholic controversialists: historical and rational arguments were intertwined. A long-standing debate over the foundation of Christian faith caught many Englishmen's attention.

\footnotetext{
82 Burnet, A Vindication of Ordinations of the Chruch of England (London, 1677), 53-4.

83 John Sharp, A Sermon Preached on the Day of the Public Fast, April the 11th. 1679 (London, 1679), 5-6.

${ }^{84}$ John Coffey and Paul Chang-Ha Lim, eds., The Cambridge Companion to Puritanism (Cambridge: Cambridge University Press, 2008), 109.

${ }^{85}$ Spurr, The Restoration Church of England, 1646-1689, 115.
} 
This debate over the 'rule of faith' raised a fundamental question about the authority of church. When the Benedictine, John Sergeant (1623-1707), published an attack on the Protestants' adherence to the authority of the Scriptures, he unhesitatingly affirmed that the Catholic Church's infallibility could lead the laity to salvation through tradition which the pope, church, and councils had guaranteed throughout history. ${ }^{86}$ As to the Catholic infallibility, Sergeant's principal argument was that the oral tradition was the certain way to find out the true rule of faith rather than Scripture. ${ }^{87}$ Like historical events, for Sergeant, it was 'Tradition or Living Testimony' to guarantee the claims of the Catholic Church's infallibility. Therefore he asserted that 'Tradition is as well sufficiently certain as sufficiently plain', since 'no change in the Doctrine either is or can be'. ${ }^{88}$ Against the Catholics who had argued that Church's infallibility was the measure of the rule of faith and the oral or unwritten tradition was the infallible ground on which Christian faith rested, leading latitudinarian divines such as Edward Stillingfleet and John Tillotson offered a detailed account of the rule of faith in Christianity. ${ }^{89}$

Stillingfleet's pursuit of rational grounds for the belief that the Church of England was the true religion required that the church professed apostolic doctrine. Starting with a premise that the theological foundations of the Church of Rome were false in his Rational Account of the Grounds of Protestant Religion, Stillingfleet presented the teachings of the Early Fathers as rooted in ground far from Catholicism: the Scriptures and the creeds of the Early Church. The doctrines of the Roman Church were rejected simply because they were 'not admitted into the Ancient Creeds'. Stillingfleet stressed that 'what was not inserted in the Ancient Creeds, was not by them judged necessary to be believed by all Christians. ${ }^{90}$ This was his purpose in writing his Rational Account. For Stillingfleet, what was universally and

\footnotetext{
${ }^{86}$ John Sergeant, Sure-Footing in Christianity, or Rational Discourses on the Rule of Faith (London, 1665), 11516, 211-12; A Letter to the D. Of P. In Answer to the Arguing Part of His First Letter to Mr. G. (London, 1687), $37-40$.

${ }^{87}$ Sami-Juhani Savonius-Wroth, Paul Schuurman, and Jonathan Walmsley, The Continuum Companion to Locke (London: Continuum, 2010), 107. For the general explanation of Sergeant's theology and philosophical thought, M. A. Stewart, English Philosophy in the Age of Locke (Oxford: Clarendon Press, 2000).

${ }^{88}$ Sergeant, Sure-Footing in Christianity, or Rational Discourses on the Rule of Faith, 104; Reason against Raillery: Or, a Full Answer to Dr. Tillotson's Preface against J. S. With a Farther Examination of His Grounds of Religion (n.p., 1672), 190, 194-95.

89 John Tillotson, The Rule of Faith \& an Answer to the Treatise of Mr. I. S. Entitled, Sure-Footing (London, 1666); The Rule of Faith or an Answer to the Treatise of Mr. I. S. Entituled, Sure-Footing, \&C, 2nd ed. (London, 1676); Stillingfleet, A Discourse Concerning the Nature and Grounds of the Certainity of Faith, in Answer to J. S. His Catholick Letters (London, 1688).

90 Stillingfleet, A Rational Account of the Grounds of Protestant Religion Being a Vindication of the Lord Archbishop of Canterbury's Relation of a Conference, 56.
} 
essentially to be believed was only contained in the apostolic creeds.

He believed that the most important inheritance from the primitive church was the focus on Scripture. His conviction that Scripture was the most apostolic rule of faith was a theological weapon to demolish the Roman Catholic case for an infallible oral tradition as the rule of faith. Theological controversy over the rule of faith had captured many writers' attention. Whether the oral tradition could be infallible was a question which English Protestants had asked with the intention of pulling down the Catholic doctrine of all forms of infallibility. In dealing with the doctrines of the Catholic Church, Stillingfleet maintained the centrality of Scripture by arguing that 'it must be imputed only to the watchful eye of Divine Providence, that the Scriptures have been preserved entire to our dayes', while it had been 'of so little use in the Roman Church'. ${ }^{91}$ From his point of view, the preservation of the Scripture throughout history seemed an exercise of God's providential care for human beings.

John Tillotson was a stern critic of Sergeant's claims of Catholic infallibility. In an answer to Sergeant's Sure-Footing, Tillotson asserted that the Scriptures were 'the means whereby the Christian Doctrine hath been brought down to us'. Tillotson saw a proposition in Sergeant's argument. According to Tillotson, Sergeant assumed that 'no man can by his private Reason certainly find out the true rule of faith'. Tillotson also confronted Hugh Cressy (1605-1674) another Catholic writer with a pronounced distrust in human reason. ${ }^{92}$ Like Sergeant, Cressy thought that 'private Reason is apparently a most fallible guide' and that 'the entire Rule of faith is contained not only in Scripture, but likewise in unwritten Tradition'. ${ }^{93}$ Apart from describing how Tillotson responded to these Catholic polemicists, it is important for the purposes of this chapter to focus upon his view of the Scriptures as the sole rule of faith in relation to Cressy's dealing with the Scriptures in the primitive church.

The argument from history also served Tillotson's purposes. Tillotson acknowledged Cressy's explanation of the dark ages of church history, saying that

These worst Times of the Church, when Ignorance, Worldliness, Pride, Tyranny, \&c. reigned with so much scope: When the Popes (so wicked, so

\footnotetext{
91 Stillingfleet, A Discourse Concerning the Idolatry Practised in the Church of Rome, 194.

92 Patricia C. Brückmann, 'Hugh Paulinus Cressy [Name in Religion Serenus]', in Oxford Dictionary of National Biography (2004).

${ }^{93}$ Hugh Cressy, Exomologesis: Or a Faithfull Narration of the Occasion and Motives of the Conversion Unto Catholic Unity (Paris, 1653), 78, 544.
} 
abominable in their Lives) enjoyed so unlimited a power even over secular

Princes themselves, and much more over the Clergy. ${ }^{94}$

Tillotson's sense of the history of the Catholic Church represented a common idea of the Anglican historiography that tended to see the period before Luther as the dark ages under the control of antichristian popes and the Church of Rome. His short description of history, in particular, aimed to attack Catholic claims for the infallibility of tradition. In short, Tillotson thought that tradition was not qualified for the rule of faith due to the distortion of doctrines and practices. 'When the Whores governed Rome', Tillotson wrote, 'and put out, and put in Bishops at their pleasure; and made their own Gallants Popes, who would be sure to make a Colledge of Cardinals of such Monsters as themselves', they became 'ignorant in the Scriptures, and in every thing else and did neglect to teach the People, and to breed up any in knowledge to succeed them in their Office; and in the lewdness of their lives did surpass the vilest of the People'. ${ }^{95}$ In short, the Church of Rome destroyed the essentials of Christianity and became heretical.

Patrick also was concerned with religious truth on the basis of scriptural texts. In his Answer to a Book after the Revolution, Patrick refuted the Catholic doctrine of infallibility of tradition by claiming that tradition could not gain absolute certainty. Vincentius and Tertullian's words were used in his works to demonstrate that the rule of faith contained in 'the Divine Scripture in the first place as our Guide'. His emphasis on the scriptural revelation as divine truth rebuked those who argued for many 'false Traditions' which did not contain in the Scripture. ${ }^{96}$ How he strongly insisted on the Scripture as the basis of true faith was proved from next part of discourse. He wrote that 'St. Peter doth not say, that the Scriptures are hard to be understood. Although he admitted that there would be something hard to be understood, yet he believed that 'the rest of the Scripture, notwithstanding this, may be easy'. ${ }^{97} \mathrm{He}$ thus urged readers to read and learn the principles of Christian religion described in the Scripture.

Patrick's insistence on the primacy of scriptural authority was associated with

\footnotetext{
94 Tillotson, The Rule of Faith \& an Answer to the Treatise of Mr. I. S. Entitled, Sure-Footing, 227.

95 Ibid., 229-30.

96 Patrick, An Answer to a Book, Spread Abroad by the Romish Priests, Intituled, the Touchstone of the Reformed Gospel Wherein the True Doctrine of the Church of England and Many Texts of the Holy Scripture Are Faithfully Explained, 14-5.

97 Ibid., 21-2.
} 
his belief in the apocalyptic interpretation of history. 'it is easy to see', he thought, that 'only Men's Vices, and the Roman Church in that hard Book of the Revelation, is doomed in due time unto Destruction'. ${ }^{98}$ As for the kingdom of Christ illustrated in Daniel's prophecy, he wrote, 'They point at a state of his Church, which is not yet come; and when it doth come, will be with a vengeance to the Roman Church.' He found out some prophetic passages - Revelation chapters 7, 10, 11, and 15 describing that the false church 'will be utterly overturned, to make way for the setting up of Christ's Universal and Everlasting Kingdom'. ${ }^{99}$ It was clear that Patrick believed that the Scripture clarified the mystery of divine providence.

The authority of the Early Father of the Christian Church was also of importance in Anglican apologetics. Many conformists in the Church of England stressed these ancient Christians' words. Tillotson turned his eyes to the primitive Father Eusebius to prove that the testimonies of the primitive Christians guaranteed the veracity of the Scripture. Tillotson took part of the ancient church historians' account on the disciples' commitment to writing the gospel. ${ }^{100}$ From Eusebius's description of ecclesiastical history, Tillotson made it clear that 'the Apostles thought it necessary for the preservation and secure conveyance of the Christian Doctrine that it should be put into Writing, and that they judged this a better way to supply the want of their presence than Oral Tradition'. ${ }^{101}$

Stillingfleet emphasized the return to the primitive tradition by showing St. Paul's defence against some imputations made by the Jews. His sermon entitled the Reformation Justified: Preached at Guild-Hall Chapel (1673) described St. Paul's appeal to the Scriptures and the pure authority of primitive Christianity. Stillingfleet assumed that the Reformation could be justified by the same argument which St. Paul made for Christianity. In response to the prosecution of the high priests and the members of the Sanhedrin, Stillingfleet wrote, Paul's defence relied upon two authorities: 'Scripture as the ground and rule of his faith, and the best and purest

\footnotetext{
98 Ibid., 22.

${ }^{99}$ Ibid., 54-5.

100 Tillotson wrote the history of writing the Scripture: 'That the Romans were not content with the Doctrine Preached, unless it were also committed to Writing; and therefore did earnestly beg of Mark, Peter's Companion, that he would leave them a Monument in Writing of that Doctrine which had been deliver'd to them by word of mouth. And this was the occasion of the writing of St. Mark's Gospel. And Peter did understand that this Work was publish't (being suggested by the Divine Revelation of the Holy Spirit) it is said he was very much pleased with the ready and earnest desire of those Persons; and that by his Authority he confirmed this Writing, to the end that it might be everywhere read in the Church'. Tillotson, The Rule of Faith \& an Answer to the Treatise of Mr. I. S. Entitled, Sure-Footing, 320-21.

101 Ibid., 320-22.
} 
antiquity'. ${ }^{102}$ It was plain that, for him, the words of Scriptures was so clear to every human reason that the people were not to submit the Scriptures to the present authority of the church as the people were bound to believe Christ to be the true Messiah through the Scriptures while 'the high priests and elders' in the Jewish Church condemned Jesus for 'a deceiver and malefactor'. ${ }^{103}$ The next part of Paul's defence was as to the object and manner of worship. By Paul's appealing to the 'best Antiquity' Stillingfleet meant the reformation of abuses and corruptions among doctrines: "no new Religion ... but the very same in substance with that which all the Jews have owned'. ${ }^{104}$ Thus the plea for the authority of the Scriptures led to the justification of the Reformation which he believed to be based upon the rehabilitation of primitive simplicity and purity. Stillingfleet's reference to St Paul contrasted with the Catholic claim of apostolic succession. The authority of papacy was based upon the story that the religious power of the bishop of Rome could be traced back to the apostle Peter.

Stillingfleet explicitly argued the Scripture was the most rational and apostolic way for Christians to gain salvation. While defending the Reformation as the reemergence of the true church against Rome, he compared the Anglican adherence to the Scripture with Paul's apologetics. It was clear that the Church of England was the true church for its pursuit of purity in the primitive church. ${ }^{105}$ In this line of argument, he believed that he could demonstrate how far the Roman Church went away from the spirit of the primitive church. Stillingfleet made use of many Fathers' testimonies encouraging Christians to read the Scripture. Ignatius, Polycarp, Clement of Alexandria, Tertullian, Origen, Chrysostom and other Fathers of the Church, wrote Stillingfleet, advised Christians to attend to 'Reading, Prayer, Teaching, Meditation therein day and night, to lay up in their hearts not only the new Oracles of the Gospel, Apostles and Apocalypse, but the old ones too of the Law and the Prophets'. The Reformation was the revelation of true religion in terms of the rebuilding of primitive faith after the age of all the heresies 'which had risen in the Church before the

\footnotetext{
102 Stillingfleet, The Reformation Justified: In a Sermon Preached at Guild-Hall Chappel Septemb. 21. 1673 before the Lord Major and Alderman, 21.

${ }^{103}$ Ibid., 24.

104 Ibid., 33-4.

105 Jacqueline Rose, Godly Kingship in Restoration England: The Politics of the Royal Supremacy, 1660-1688 (Cambridge: Cambridge University Press, 2011), 146.
} 
sixteenth century, ${ }^{106}$

Theological debate over the rule of faith between these latitudinarian clergy and Catholic apologists indicates that the historical notion of conflict between true and false religion underlay the basic premise of anti-Catholic argument of the conformists. In a sermon before Charles II, Tillotson stressed that false religion had a long history even before the depravity of the Church of Rome. 'The Church of Rome', said he, was not 'the first who called it heresy to reject human Traditions, and to make the Scripture the Rule of Faith; this was done long before by their reverend Predecessors, the Scribes and Pharisees'. ${ }^{107}$ However, in the same sermon, he showed his moderate opinion of the Church of Rome. He admitted that some parts of faith in the Church of Rome were shared by the Church of England. For example, the two churches held the articles of the Apostles Creed pronounced by the first four General Councils. He did not regard the Catholic Church as entirely corrupt, acknowledging that the faith of the Church of Rome had the same origin as the Church of England did: antiquity. Nonetheless, the most significant distinction of the Church of England from the Roman Church was plain to him.

We believe and teach all that is contained in the Creeds of the ancient Christian Church, and was by them esteemed necessary to Salvation. But the Church of Rome hath innovated in the Christian Religion, made several additions to it, and greatly corrupted it both in the Doctrines and Practices of it. $^{108}$

For Tillotson, the Church of Rome did not differ from Babylon, a biblical reference to false religion, because Rome could not acknowledge its error and accept the Reformation. Again, he showed his hope for the possibility of reform of the Church of Rome. Because 'they still retain the Essentials of Christianity, and profess to believe all the Articles of the Christian Faith, he carefully wished them to be esteemed as a true church notwithstanding their corruptions. ${ }^{109}$

\subsection{The Continuity between the Church of England and the Primitive Church}

These arguments about the continuities between the Early Church, the papal Church

\footnotetext{
106 Stillingfleet, A Discourse Concerning the Idolatry Practised in the Church of Rome, 198, 200-3.

107 Tillotson, The Protestant Religion Vindicated from the Charge of Singularity \& Novelty in a Sermon Preached before the King at White-Hall April the 2d, 1680 (London, 1680), 22.

${ }^{108}$ Ibid., 23.

109 Ibid., 29.
} 
of Rome, and the reformed Church of England, were concerned with church government as well as doctrine. Since the Tudor Reformation, the Church of England had been repeatedly asked by Catholic adversaries, 'where was your Church before Henry VIII?' The sixteenth-century English church had a number of different answers to this troubling challenge, but by the early seventeenth century a prominent group of Anglican clergy was willing to recognise the Church of England as continuously descended from the medieval Church. These Laudian or 'High Church' divines were comfortable with the notion of an apostolic succession of English bishops which had been passed down through consecration in the medieval Roman Catholic church. This implied that the medieval church and the contemporary Catholic Church were not fundamentally false even though they were corrupt and erroneous in many ways. For all its corruptions, in the eyes of early seventeenthcentury Laudians, the Church of Rome had retained 'the essence of a true church', and hence, this did not amount to the severe anti-popery view. Some Laudians such as Montagu even considered the possibility of 'a reunion of the English and the Roman churches'. 110

In the later seventeenth century, the latitude-men preferred to reject the historical succession of the Church of England from the medieval Catholic Church. For them any possibility of assent to the connection of their church with the Roman Church could undermine the justification of the English church's break with the medieval church. Burnet's anti-popish outlook led him to deny that the Roman bishops succeeded the disciples and apostles. He insisted that the Rome's claim that St. Peter was the rock upon whom their church was built did not prove the succession of the Roman bishops to the apostle. By a biblical verse, 'the keys of the kingdom of Heaven' (Matthew, 16:19) he meant that St. Peter was to open the Gospel which was usually called, 'the Kingdom of God, or of Heaven in the New Testament'. For him this biblical expression showed the apostle's 'honour who did first publish the Gospel both the Jews and Gentiles, and in particular did first receive the Gentiles into the new Dispensation'. ${ }^{111}$ In his view, there was no relationship between the primitive Church Fathers and the Bishops of Rome.

Stillingfleet took a similar view. He provided a lengthy and comprehensive

\footnotetext{
110 Spurr, The Post-Reformation: Religion, Politics and Society in Britain, 1603-1714, 75.

111 Burnet, The Mystery of Iniquity Unveiled in a Discourse, Wherein Is Held Forth the Opposition of the Doctrine, Worship, and Practices of the Roman Church, 46.
} 
examination of traditional evidence about the ancient churches in England. Justin Champion has carefully traced Stillingfleet's thought of the continuity between the ancient church and the Church of England. His Origines Britannicae, or the Antiquities of the British Church (1685) was designed to 'to give as clear and distinct a view of the state and condition of the British Churches, from their first plantation to the conversion of the Saxons'. ${ }^{112}$ His book aimed to 'examine the tradition, concerning Joseph of Arimathea, and his brethren coming hither to plant Christianity', to show that 'there was a Christian Church planted here, in the apostles times', and 'to prove the great probability, that St Paul first founded a Church here'. ${ }^{113}$ Having denied the traditional belief that Joseph of Arimathea came over to Britain to preach the Gospel, Stillingfleet insisted that many Fathers' testimonies granted that some of apostles preached the Gospel in Britain and that 'there cannot appear any improbability that he should come into Britain, and establish a Christian Church here'. ${ }^{114}$ Stillingfleet went on to argue for the 'pre-Lucian Christianity' to legitimate the Anglican settlement against the Catholic argument of the origin of the church in England. Stillingfleet asserted that the English church was existent before the apostolic succession - thanks to Lucius' conversion. ${ }^{115}$ This drew the discussion of ancient history of Christianity into his argument that there had been a succession of English bishops from primitive Christianity to the present day. In the subsequent discussion of the nature of church government, Stillingfleet affirmed the validity of episcopacy. His work argued that episcopacy was 'the traditional mode of ecclesiastical government'. ${ }^{116}$ Although his intention was to provide more certain evidences to vindicate the idea of true model of Church system so there was little use of apocalyptic terms made by the author, his historical examination, more importantly, reinforced an idea of the Church of England as a true church guaranteed by the apostles.

The latitudinarians' rational appeal to the authority of the primitive church was not always appreciated by other Anglicans. John Warly, for example, was not persuaded that the latitudinarians always made the strongest case: they were too

\footnotetext{
112 Stillingfleet, Origines Britannicae, or, the Antiquities of the British Churches with a Preface Concerning Some Pretended Antiquities Relating to Britain, in Vindication of the Bishop of St. Asaph (London, 1685), preface, i.

${ }_{113}$ Ibid., 6.

114 Ibid., 39-41.

115 Champion, The Pillars of Priestcraft Shaken: The Church of England and Its Enemies, 1660-1730, 61.

116 Ibid., 61-2.
} 
interested in appealing to reason and their own ingenuity and did not invoke the sheer authority of the Early Fathers of the Christian Church. He thought that they 'dispute against their Adversaries in a rational way without pressing the Authority of some ancient Fathers; seeing it is possible to shew, that the most valuable Arguments which are made use of as a Battery against Atheists are not the meer products of their own inventions, but of others whose names are conceal'd by them'. ${ }^{117}$

Many historians have acknowledged the late seventeenth-century Anglican interest in the early church, but they have focused less upon the latitudinarian historical study of the primitive church and more upon the claims of reason in the search for theological certainty. This trend resulted in the relative neglect of these Anglican divines' appeal to the primitive church. According to Robert D. Cornwall, modern scholarship has overlooked the latitudinarians who looked back to the primitive church in order to plant its virtues in the Church of England. ${ }^{118}$ This implied a lack of attention to the latitudinarians' concern with tradition. With continuous interest in the providential history of the church, their devotion to the study of the primitive church was no less than other Protestants. Their emphasis on primitive Christian virtues, including reading the Scripture as the rule of faith, shows that the history and scripture were as important as human reason in shaping the latitudinarians' rational theology.

\subsection{Motives for Further Reformation}

The primitivism of the Church of England and its identity as a 'true church' with providential protection did not mean that the reformation of the church or its parishioners was complete. Although English Protestants thought that the Tudor Reformation had begun the rehabilitation and purification of the church, it still had a long way to go. During the seventeenth century, many Protestants felt that they should do more to achieve the perfection of their church for eternal salvation. Different groups had different priorities. As English puritans saw only a partial reform in the principles of the Church of England, they had raised a call for a further reformation of worship, liturgy, doctrine and personal piety. They promoted a

\footnotetext{
117 John Warly, The Reasoning Apostate: Or Modern Latitude-Man Consider'd, as He Opposeth the Authority of the King and Church (London, 1677), 3-4.

118 Robert D. Cornwall, 'The Search for the Primitive Church: The Use of Early Church Fathers in the High Church Anglican Tradition, 1680-1745', Anglican and Episcopal History 59, no. 3 (1990): 304.
} 
'reformation of manners' which was intended to allow the 'saved' to live a godly life without disturbance from the ungodly and profane masses. Many Protestant writers exhorted the prophetic fulfilment of the reformation to the civil magistrates and the church as well. ${ }^{119}$ It is not surprising to see that Anglican endeavours to identify the Church of England with the primitive church naturally included an emphasis on the need for individuals and communities to commit themselves to a life of personal piety along the lines of the Early Christians.

The calls for further Reformation in the lives and religion of English Protestants were insistent. They laid much emphasis on the example and benefit of 'primitive piety' and its positive attractions if only people would appreciate them. But they also warned of divine retribution for those who squandered opportunities or ignored the warnings of divine providence. John Sharp's sermon preached at St. Margaret's, Westminster, in 1679, applied the epistle to the Church of Ephesus in the Book of Revelation to the Church of England. As he described in this sermon, the Church of Ephesus 'had walked very worthily, and are much commended by our Saviour, for their Zeal and Piety and Labour in Religion, but now they were fallen to a great degree of negligence and remissness'. ${ }^{120}$ In his comparison, Sharp claimed that the Church of England needed to fear the same judgment as the Ephesian Church because it had lost its first love for Christ. The ordinary course of providence would bring divine punishment to England unless the reigning vices would be prevented by 'a speedy Reformation'. ${ }^{121}$ For him, the Reformation was not yet finished.

This sense of an unfinished Reformation drew Anglican attention to the situation of the Church of England or Protestantism in a broader sense. During the seventeenth century many Anglicans were concerned with the spiritual and temporal dangers amongst them. They easily recognised not only the Catholic attack on the Anglican Church but also all kinds of heretical or immoral ideas which were thought to prevent the people from gaining access to the truth of Christian faith as posing a threat to the full reformation. They believed that providential workings of God had controlled the fate of the true church. But they also thought that the history of the Church of England from the Reformation ensured the need for human efforts to secure the completion of the Reformation.

\footnotetext{
119 Walsham, 'History, Memory, and the English Reformation', 921-22.

120 Sharp, A Sermon Preached on the Day of the Public Fast, April the 11th. 1679, 3.

121 Ibid., 9.
} 
The latitudinarians were no exception. Burnet did not deny the presence of some defects in the Reformed church, even though his works mainly focused upon the repudiation of Roman Church and, then, upon the progressive advance towards the perfect true church. Most urgent, for him, was to encourage the laity to live the holy life to come ever closer to a future state of perfection. In his introduction to the second volume of History of the Reformation in 1681, Burnet acknowledged that 'our Reformation is not yet arrived at that full perfection, that is to be desired'. ${ }^{122}$ Burnet frequently complained of the present status of the Protestant Church as void of sincere piety. He thought that the present church made the human life languish in 'lassie[lazy] Devotion, without studying to serve God in our Generation', and argued that this was 'contrary to the intendment of Religion'. ${ }^{123}$ Burnet wrote, however, that the poor conditions for maintaining Christian virtues could not be ascribed to the Church of England, its doctrines, and its worship. For all unsatisfactory aspects, it was obvious the Church of England had not 'got our People befooled into such perswasions', as those who 'handle the Word of God deceitfully and draw the People even to do good with a crafty guile, or lye for God'. Therefore, 'with a quiet Mind and good Conscience', Burnet expected that 'every one may hold Communion with our Church, and hope for Salvation in it', once the church would preserve the pure nature of Christian faith. For this purpose Burnet repeatedly emphasised the core principles: worshipping God in spirit, 'as a Spiritual Being, with suitable Adorations', identifying neither image nor symbol with the divine nature, and teaching that 'we ought not to figure God to any corporeal being, no not in our thoughts; neither do we worship any, beside God the Father, Son, and Spirit: We also worship Christ, but as he is God'. ${ }^{124}$ Having examined Burnet's case, we can understand that the vindication of succession of the Church of England from the primitive church necessarily entailed this discourse of more progressive Reformation among the Englishmen due to the perception of the Reformation as incomplete.

The motive for the completion of the Reformation, however, was not only caused by the yearning for the ideal nature of the primitive church. The Anglican perception of the contemporary geo-political situation of Protestantism accorded

\footnotetext{
${ }^{122}$ Burnet, The History of the Reformation of the Church of England, 2, sig. c2r.

123 Burnet, The Mystery of Iniquity Unveiled in a Discourse, Wherein Is Held Forth the Opposition of the Doctrine, Worship, and Practices of the Roman Church, 147-48.

124 Ibid., 148-49.
} 
closely with the spiritual tension between the antichristian false church and the apostolic true church. Burnet's view provides a useful example here. It is obvious that Burnet had a sense of fear that the Roman church was threatening the Protestants including England. As a result of the Counter-Reformation, he saw European Protestantism as embattled and stagnant. As noted above, the historical memories of Catholic horror in England, such as Marian persecution, the threat of the Armada, and the 1605 gunpowder plot, reminded him of the unfinished Catholic threat against England. While the Catholic clergy counterattacked against the reformed churches, he lamented, the Protestants 'go back', forgetting that they had enjoyed significant success in the sixteenth century. ${ }^{125}$ In Burnet's mind, the main reason why Protestantism was on the wane was because it had lost the spirit of the first Christians and Reformers. It no longer implanted primitive Christianity into the heart of Protestantism, but had lost its exemplary holiness. ${ }^{126}$ This vitalised the claim for the return to the purity of early Christianity through rejoicing in the revival of spiritual and a holy life of faith.

Stillingfleet was another who warned of the danger of Catholicism as a means of improving and preserving Christian virtues among the Protestants. In general, he saw the Christian world in danger. Many churches in Europe were returning to their former corrupt state:

If we look at this day into the State of the Christian World; how great a part of it is relapsed into almost Heathen Superstition, in the Worship of Images, and Saints, and Angels as Mediators? ${ }^{127}$

Preaching on a fast day 1678, Stillingfleet shared Burnet's fears of a Catholic conspiracy to undermine the Reformed church. Stillingfleet warned that though the English church 'enjoyed a firm establishment under the care and conduct of a wise and cautious Government', there had been continuous conspiracies with 'restless endeavours' in the reign of Elizabeth I and that the reformed church 'enraged our Adversaries of the Roman Church, and made them the more restless to destroy it'. ${ }^{128}$ In another sermon, he urged that 'we have busie and restless Adversaries abroad' as

\footnotetext{
125 Burnet, A Sermon Preached in the Chappel of St. James's, before His Highness the Prince of Orange, the $23 d$ of December, 1688, 5 .

${ }_{126}$ Claydon, 'Latitudinarianism and Apocalyptic History in the Worldview of Gilbert Burnet, 1643-1715', 587.

127 Stillingfleet, 'Sermon XX: Of the Nature of Superstition Preached at St. Dunstans West March 31, 1682 ', in Fifty Sermons Preached on Several Occasions (London, 1707), 333.

${ }_{128}$ Stillingfleet, 'Sermon XVI, Preached on the Fast-Day at St. Margaret's Westminster, November 13. 1678', in Fifty Sermons Preached Upon Several Occasions (London, 1707), 233, 48.
} 
the Jews of Jerusalem had against St. Paul' ${ }^{129}$ It was important, however, for him to expect the victorious future of the true church. Looking back on the reformed church's history, Stillingfleet felt that Englishmen had 'the less reason to be discouraged with present difficulties, or disheartened with the fears of future dangers' because he firmly believed that the divine providence which 'over-rules all the Counsels and Affairs of Men' had defeated all the cruel schemes of 'his and our Churches enemies' and had given 'the liberty and opportunity of this day to meet together to implore the continuance of his favour and mercy towards us in the preservation of his Majesty's person'. ${ }^{130}$ His sermon had a pastoral purpose: he aimed to invigorate true religion by evoking fear of Catholic brutality. Citing the verse 1 Samuel, 7: 'returning to the Lord with all their hearts, and putting away their strange gods, and preparing their hearts unto the Lord and serving him only', Stillingfleet tried to keep the people loyal to the true religion. ${ }^{131}$ The expectation that the antichristian church would finally be destroyed in the course of the accomplishment of the prophecies through God's omnipotent authority was a strong motive to encourage morality. As opposed to the Catholic historian Baronius' opinion that the God's providence would preserve the Catholic faith, Stillingfleet asserted that the 'Devils Kingdom cannot stand, if it be divided against it self' ${ }^{132}$ To avoid the superstitious state of faith, Stillingfleet advised his congregation to hold on to true religious values. Promoting 'a high value on these Duties' which were set by God, he claimed, was no less than doing good things. ${ }^{133}$

Many sermons by Tillotson focused upon the political perils posed by the Roman Catholic church. He thanked God for 'invaluable blessing of our Reformed Religion, and for the wonderful Discovery of the large horrid and barbarous Conspiracy against our Prince, our Peace, and our Religion'. ${ }^{134}$ In another sermon, Tillotson worried about the dangers of falling back into a false faith. For him not only Catholicism but also atheism or infidelity was destroying the true faith of the Church of England. 'We are not free', said he, 'from the danger of apostasy'. He

\footnotetext{
129 Stillingfleet, The Reformation Justified: In a Sermon Preached at Guild-Hall Chappel Septemb. 21. 1673 before the Lord Major and Alderman, 37.

130 Stillingfleet, 'Sermon XVI, Preached on the Fast-Day at St. Margaret's Westminster, November 13. 1678', 232-33.

131 Ibid., 234

132 Stillingfleet, A Discourse Concerning the Idolatry Practised in the Church of Rome, 343.

133 Stillingfleet, 'Sermon XX: Of the Nature of Superstition Preached at St. Dunstans West March 31, 1682 ', 338.

134 Tillotson, A Sermon Preached November 5, 1678 at St. Margarets Westminster, before the Honourable House of Commons (London, 1678), 35.
} 
lamented that many people who professed Christianity undermined the principles of true religion: 'the belief of God, and his providence, and the immortality of the souls of men, and a state of rewards and punishments after this life'. ${ }^{135}$ Even if the purity of Christian doctrine and worship was recovered by the Reformation, he asserted, 'apostasy from the living God' rendered the Church damaged by 'gross errors and superstitions, which the reformation had pared off, and freed us from'. ${ }^{136}$ For him, the real reformation needed to be accomplished by restoring the ancient creeds of the Christian church which inculcated the principles of 'good life', 'sincere repentance, and perfect contrition for our sins'. ${ }^{137}$ Simon Patrick was also anxious about the apostate Church of Rome. In his sermon preached before the prince of Orange, he said that 'there was such a foul Apostasie as we now see in the Church of Rome where great number of Christians became Wolves, Leopards and Tygers again'. ${ }^{138}$

Alongside a call for vigilance against potential threats, the demand for a stronger commitment to the movement for moral and religious reformation was repeated after the Revolution of 1688-89. In a sermon preached at Westminster Abbey on the 5 November 1691, Sharp again was worried about the circumstances in which the Church of England was placed. In commemoration of the discovery of the Gunpowder Plot, he thanked God for his protection of the church and state from the popish threat. 'How many Plots and Conspiracies', he said, 'were laid in the Time of the Glorious Q. Elizabeth, to put an End to her Life, and with it, to our Reformed Establishment?' He continued:

Blessed be God, (who hath never failed to raise up Deliverers to his People in the Day of their Distress) that Storm is blown over: And we are here, not only in Peace and Quietness, in the full possession of our Native Rights and Liberties, and in the Enjoyment of the free Exercise of our Religion ... But such is the Deliverance that God hath wrought for us, that we also seem to have a fair Prospect of the Continuance of these Blessings among us. ${ }^{139}$

However, even though Sharp believed that God had taken care of his church in England and Europe, he urged his congregation not to be complacent about the

\footnotetext{
135 Tillotson, 'Sermon LXVII: The Danger of Apostasy from the True Religion', in The Works of the Reverend Dr. John Tillotson, vol. 6 (Dublin, 1739), 126.

136 Ibid., 127.

137 Ibid., 129-29.

138 Patrick, A Sermon Preached at St. Paul's Covent-Garden on the First Sunday in Lent, 19.

139 Sharp, 'Sermon X. Preached before the Lords Spiritual and Temporal in the Abbey-Church at Westminster, on the 5th of November, 1691', in Fifteen Sermons Preached on Several Occasions, vol. 1 (London, 1722), 313-14.
} 
current state of the Protestant Church. That 'we all firmly adhere to the Principles of our Religion; and that in our Practices we conform ourselves to those Principles' was the main argument of his sermon. ${ }^{140}$

To sum up, the latitudinarian clergy acknowledged the possibility of religious progress. Their apocalyptic understanding of history of the Reformation strengthened their belief that the Reformation was a momentous event in Christian history. The establishment of the Church of England was remembered as a providential triumph of the godly. The Protestant historiographical tradition enabled them to argue that the Church of England possessed an undeniable claim to be part of the genuine 'catholic' church.

On the other hand, however, their concern with the apocalyptic interpretation of the Reformation also posed a challenge to them. The Henrician Reformation was itself a glorious victory. Yet, when it came to their contemporary situation, they thought that the good fruits of the Reformation were scant within the Church of England. Thus they promoted the idea that the Reformation was yet to be finished, and that real reform of the church was not the invention of new doctrines and practices but the restoration of the primitive church. Given that their apocalyptic historiography connected the reformation with the restoration of orthodoxy based upon the primitive Fathers, the latitudinarians' thinking was largely in line with the mainstream of contemporary Anglican apologetics. The claim for further reform associated with the restoration of primitive principles continued to remain central to Anglican moderate writers' argument for religious reforms in the eighteenth century. ${ }^{141}$

Burnet, Stillingfleet, Tillotson, Patrick, and Sharp's interpretations of the contemporary circumstances surrounding the Church of England reflected the latitudinarians' providential view of the conflict between the true and false churches. Their insistence on the providential belief was not limited to the vindication of the reformed church but expanded to the justification of the civil magistrates' power as

\footnotetext{
140 Ibid., 315.

141 Robert G. Ingram, Religion, Reform and Modernity in the Eighteenth Century: Thomas Secker and the Church of England (Woodbridge: Boydell Press, 2007), 12-3.
} 
the guardian of the Church of England, which is to be explored in the next chapter. 


\section{Chapter 4 \\ The Latitudinarian Ideal of the Godly Ruler}

Politics and religion were tightly interconnected in early modern England. As Protestants thought that the English Reformation rested upon co-operation between the monarchy and Parliament, they were preoccupied with the complex relationship between political agents and religious ministers afterwards. The Church of England, especially, was the product of this relationship, so its allegiance to the monarchy was the key element in the Anglican understanding of political and religious issues. ${ }^{1}$

This chapter examines first the way in which the latitudinarians' perspective on the godly role of the civil magistrate was shaped by their apocalyptic justification of monarchical authority. Basically, their attitude towards the duty of the monarch in religion and church matters was articulated through a range of different languages and rhetoric. They used different rhetorical strategies on various occasions. In particular, their ideas of royal authority over the church were explained through the biblical understanding of political authority. The chapter shows that these moderate Anglicans understood the nature of the English monarch's authority by applying their apocalyptic imagination to the political situation in the later seventeenth century. Modern scholarship has explored the early modern discussion of the relationship between royal power and ecclesiastical authority that had been a prominent issue among the English thinkers since the Reformation. Recently, Jacqueline Rose's description of religious polemics surrounding royal supremacy during the Restoration period has detailed the long history of conflicts and compromises in relation to the relationship between crown, parliament, and the established Church of England. Anglican polemicists argued that the royal governors were the protectors of the established church. In this sense, royal supremacy over the church was a key issue for the latitudinarians who thought the monarchical control of the re-established church was legitimate and necessary. ${ }^{2}$

Secondly, the chapter attempts to examine the political stance of the latitudinarians through their literature including sermons, treatises, and other writings

\footnotetext{
1 Jacqueline Rose, 'By Law Established: The Church of England and the Royal Supremacy', in The Later Stuart Church, 1660-1714, ed., Grant Tapsell (Manchester: Manchester University Press, 2012), 21-2.

${ }^{2}$ Rose, Godly Kingship in Restoration England: The Politics of the Royal Supremacy, 1660-1688 (Cambridge: Cambridge University Press, 2011).
} 
and place their opinion in a political context. The Restoration period provided important political circumstances for the intellectual transformation of England. The latitudinarian clergymen's political ideology also reflects the variety of political ideas developed by different thinkers. The experience of the Interregnum had changed their perception of political and religious situations; their political thought was developed during the Restoration; the English Revolution made them look at the status-quo in complicated ways. Therefore, it is useful to examine their legitimization of the royal supremacy through their own rhetoric - the combination of an apocalyptic justification of the monarch and an allegedly Erastian interpretation of the relationship between the king and church. As early modern Anglicans largely made their efforts to clarify the relationship between priestly authority and monarchical jurisdiction over the church, the latitudinarians also contemplated such issue. Although their thought about the nature of politics and civil authority was not explicit in their ecclesiastical works, yet they insinuated their reflections on the relationship between civil and ecclesiastical authorities. In other words, how they combined traditional ideas with the emerging discourse of political ideology was apparent in their discussions of the role of the civil ruler in religion.

Historians have explored the dynamic complexity of political ideas in early modern England. Recent studies suggest that the invention of modern intellectual languages. which, directly or indirectly, had an impact on the creation of a relatively new cultural environment in the eighteenth century, should not only be ascribed to secular thinkers but also to the religious controversialists of the era. It is widely acknowledged that the development of political ideas during the early modern period, especially, owed a great debt to debates between intellectuals who were deeply involved in religious issues. Research into the religious contests between competing groups has shed light on the innovative thinking behind apparently modern intellectual concepts. One of the remarkable issues to which many historians have paid attention was the change in understandings of the relationship between the secular government and church during the seventeenth century. The Restoration saw a variety of discourses about the role to be played by government in the affairs of the church. There was a broad spectrum of attitudes among Anglicans on the question of episcopal power and autonomy. This ranged from the 'high-flying' discourse of jure divino (or iure divino) episcopacy to the utilitarian view that the bishops were simply 
a useful tool to keep peace in the country, to vote in the House of Lords, and to preach before the royal court as needed. What stance the seventeenth-century contemporaries took very much depended upon how they understood state-church relations.

\subsection{The Anglican Commemorations of the Restoration Monarch}

To understand the political framework in which the latitudinarians viewed the relationship between the church and the monarchy, we should begin by surveying their use of apocalyptic language. As Rose says, they were deeply concerned with 'how to make the magistrate godly' from a religious perspective. ${ }^{3}$ The term 'godly ruler', especially, was the common feature of English Protestant literature.

The notion of the godly prince came from the apocalyptic aspirations of sixteenth-century reformers. The idea was adopted to identify the pope with Antichrist and claim that civil rulers were anointed by God so they were elected to protect the true faith in the context of apocalyptic warfare. ${ }^{4}$ As the supreme head of the church, the monarch was described through scriptural terms and passages. The latitudinarian divines followed the Reformation tradition to describe the civil magistrate during the late seventeenth century. Their sermons delivered on special days and printed works were devoted to promoting the idea of the 'godly ruler'.

Many historians have argued that the idea of the godly ruler was developed as part of English millenarianism. ${ }^{5}$ William Lamont, for example, has paid attention to the continuity of this apocalyptic idea. Lamont goes so far as to claim that millenarian convictions were implicit in the early modern mind, and that the political changes in early modern England transformed millenarianism into a variety of types of political and religious ideals: godly prince, godly bishop, godly people, and godly parliament. ${ }^{6}$ Lamont shows that modern apocalyptic thought was much influenced by traditional millenarianism in terms of the concept of 'godly rule'.

This political idea was deeply involved with religious expectations of an

\footnotetext{
3 Ibid., 3 .

${ }^{4}$ John Guy, 'The Henrician Age', in The Varieties of British Political Thought, 1500-1800, ed., J. G. A. Pocock (Cambridge: Cambridge University Press, 1993), 33.

5 Margaret C. Jacob, 'Millenarianism and Science in the Late Seventeenth Century', Journal of the History of Ideas 37, no. 2 (1976): 337; M. C. Jacob and W. A. Lockwood, 'Political Millenarianism and Burnet's Sacred Theory', Science Studies 2, no. 3 (1972): 266-67.

${ }^{6}$ William M. Lamont, Godly Rule: Politics and Religion 1603-60 (London: Macmillan, 1969).
} 
utopia where the godly king, whether he was Christ himself or a human agent sent by God, would govern the world, defeating the tyrannical Antichrist. From the Reformation onwards, the expectation of a godly ruler to achieve what God originally designed had been encouraged from the pulpit. For example, John Foxe's apocalyptic hope for godly rule had been inherited by many seventeenth-century polemicists. In the sixteenth century, Foxe's millenarianism fuelled the apocalyptic apologetic for the role of Christian prince in the triumphant moment of the Christians against Antichrist. Foxe's vision of the godly rule influenced the seventeenth-century Protestants. Apocalyptic rhetoric of this kind was not the reserve of any specific religious sect or tradition. The millenarian interpretation of the nature of monarchy varied depending on religious faith. Not only did radical sects, such as the Fifth Monarchists or Diggers, support millenarianism, but Anglican bishops who had espoused jure divino episcopacy following Foxe's belief in godly rule, and the moderate Presbyterian Richard Baxter, also shared it. ${ }^{7}$

The restoration of the monarchy in 1660 influenced the religious climate of English Protestantism and gave a new lease of life to the apocalyptic illustration of the civil ruler as the godly protector of the true church. The restored Church of England expected the civil ruler to re-establish a strong alliance between the church and monarchy. Anglican clergy claimed the duty of the civil magistrate to protect the church and society, and monarchical and parliamentary efforts to promote the reestablishment of the Church of England in turn fostered Anglican loyalty to the Stuart monarchy.

The most traditional genre to convey the political ideology was sermon preached on special occasions. In the religious calendar of the Anglican Church ceremonial days, such as anniversaries of the Restoration of the Stuart monarchy (29 May), of the Gunpowder Plot (5 November), and of the execution and martyrdom of Charles I (30 January) celebrated and commemorated the 'godly ruler' in providential language. Every parish church followed the special liturgy for these days and sermons were preached that spoke of the issues of the anniversary. The monarch was expected to attend the royal chapel for these ceremonial events. ${ }^{8}$

On these occasions the latitudinarian divines preached politically-themed

\footnotetext{
7 Ibid., 40-6; Jacob and Lockwood, 'Political Millenarianism and Burnet's Sacred Theory', 267.

8 Anna Keay, The Magnificent Monarch: Charles II and the Ceremonies of Power (London: Continuum, 2008), 154.
} 
sermons which were full of the biblical rhetoric of the godly rule and blessings of the sacred monarchy. On 30 January 1669 Stillingfleet commemorated the execution of the King Charles I in a sermon preached before the restored King Charles II. In this sermon, he juxtaposed the English king and the Church of England with the two biblical figures of Moses and Aaron who represented the king and church. Seeing the dynamic change in politics, he appreciated divine providence controlled the English monarchy. His mournful words on the tragedy of the previous king were followed by praise of the providential restoration of his son, Charles II. Stillingfleet claimed that God 'took away one of the best of Kings from us in his wrath'. However, he continued 'blessed be that God, who in the midst of judgement was pleased to remember mercy, in the miraculous preservation, and glorious restauration of our Gracious Soveraign'. 9 His basic understanding of the monarch was part of his belief in divine providence. In a sermon preached on another fast day, 13 November in 1678 , he celebrated the restoration of monarchy, saying that 'after all our intestine broils and confusions which our sins had brought upon us, God was pleased in a most surprising manner, without War or bloodshed, ... to restore our Soveraign to his Throne, our Church and People to their just Rights and Liberties.' He went on to assert his belief in the ideal condition of politics by saying that 'That is certainly the happiest condition of a people, where the Prince sits upon the Throne of Majesty and Power, doing righteousness and shewing kindness; and the people sit every man under his Vine, and under his Fig-tree, enjoying the fruits of his own labours, or his Ancestors bounty'. ${ }^{10}$ Without the best government under the best monarch and laws he believed that the kingdom would never preserve its happiness. This providential sense helped him to believe that the English king must be supported by divine power.

Like Stillingfleet, John Sharp was also concerned with the role of civil magistrate in protecting and overseeing the Church of England. One 30 January sermon, preached before the House of Lords, took as its text Titus 3: 1 - 'Put them in mind to be subject to principalities and powers to obey magistrates'. Sharp claimed that 'we are all bound, as we have Occasion, to Preach up Loyalty and Obedience to our Governours'. ${ }^{11}$ He emphasised that clergy had responsibility for instructing the

\footnotetext{
${ }^{9}$ Edward Stillingfleet, A Sermon Preached before the King January 30, 1669 (London, 1669), 42.

${ }^{10}$ Stillingfleet, A Sermon Preached on the Fast-Day November 13, 1678 at St. Margarets Westminster before the Honourable House of Commons (London, 1679), 33, 42.

11 John Sharp, 'Sermon II. Preached before the Lords Spiritual and Temporal in Parliament Assembled, in the
} 
laity about this teaching. It was obvious that he idealized Charles I as the sacred king while criticizing that 'Republican Principles which have once over-turn'd our Government, and brought an Excellent Prince to an unhappy End'. ${ }^{12}$ He made use of apocalyptic rhetoric in his sermon preached on the fast day, 11 April, 1679. He applied the image of seven churches in Revelation 2: 5 to circumstances in which the Church of England was recognised as being threatened by competing religious groups, above all by Catholics and especially the heir to the throne, James, Duke of York. He warned that the candlestick of the Church of England would be removed by God due to the 'restless busie Religion that has made so much disturbance in Christendom'. 13

The Catholic pretension of having the power to depose the prince seemed to be heretical to Sharp. The Popish Plot was thought to be a Catholic conspiracy to take away the life of the civil magistrate and to overthrow the episcopal government of the English Church. Thus, for him, apocalyptic deliverance of Englishmen from the menace of Roman principles was wondrous. 'The blessed be Gods Name', he praised, 'that this Cursed Design has been hitherto Defeated, and we are here to Praise him for it, and to Pray to him for a farther Discovery of it'. ${ }^{14}$

Sermons were full of blessings of providential deliverance. Sharp audibly expressed how divine mercies were showered upon the English people. He venerated divine providence for discouraging 'Atheism and Contempt of Religion, as also Lewdness and Debauchery of all kind' and putting a stop to 'the Scandalous Schisms and Divisions that are among us'. His blessing was also aimed at the monarch. The providence of God won acclaim for securing 'the Person of His Sacred Majesty and the Rights of his Crown' against seducing attempts made by 'Papists or Others'. ${ }^{15}$ His veneration of divine design for protecting the English monarch also subsumed the responsibility of the civil magistrate. Principal tasks which God desired to undertake were shared by the secular magistrate. Both expelling false religion from England and setting up the Protestant Church of England were required to be of

Abbey-Church at Westminster, on the 30th of January 1699/1700', in Sermons Preached on Several Occasions: With Two Discourses of Conscience, vol. 2 (London, 1715), 46.

12 Ibid., 62-3.

13 Stillingfleet, A Sermon Preached on the Day of the Public Fast, April the 11th. 1679 (London, 1679), 27; Warren Johnston, Revelation Restored: The Apocalypse in Later Seventeenth-Century England (Woodbridge: Boydell Press, 2011), 150.

${ }_{14}$ Sharp, A Sermon Preached on the Day of the Public Fast, April the 11th. 1679, 33.

15 Ibid., 35. 
interest to the king and the English people. Under circumstances in which the English Protestants felt the peril of Catholicism looming large, Sharp concluded the sermon by encouraging the audience to be 'Meek, and Gentle, and Long-Suffering, even to those that differ in Opinion from us', to constantly remain loyal to the civil magistrate, and to refrain from violating 'our Allegiance to him'. ${ }^{16}$ Even though Charles II's reluctance to deny his alleged connection with Catholicism increasingly alarmed Anglicans from the late 1670s, Sharp held on to the belief in providential protection of the king and the kingdom. Therefore, he appealed to Christian virtues which were required to satisfy God so that he would preserve the government.

On 29 May 1680 Tillotson dedicated a sermon to praying for the civil government. Tillotson thought that praying for kings and all civil magistrates is paramount for he had the great influence on all Englishmen. His proposition that the secular government which could protect the peace and security of everyone's body and property was necessary to the welfare of human being excited his enthusiastic appeal to the divine preservation of the king and state.

Tillotson claimed two advantages the people could gain from the good government:

1. That by Government we are Secured in our Civil Rights and Interests, in the quiet and peaceable Possession of what is our own.

2. That we may thereby be protected in the free Practice and Exercise of Religion and Virtue. ${ }^{17}$

In explicating these benefits from government, Tillotson also showed his fears for a society without legitimate government. 'Without Government', he said, there could be no such thing as Property in any thing beyond our own Persons; for nothing but Law can make Property, and Laws are the Effect of Government and Authority'. If it had not been for the government, he claimed, the people could not have had 'no safety, no quiet enjoyment of any thing'. In a state of anarchy, he worried that 'Man must be perpetually upon his guard against all the World, and exposed to continual Violence and Injuries from those, who are too many, and too strong for him'. From this assumption, therefore, the role of the civil governor -

\footnotetext{
16 Ibid., 39.

17 John Tillotson, 'Sermon XV: The Duty and Reason of Praying for Governours Preached on the 29 of May, 1693', in Sixteen Sermons Preached on Several Subjects and Occasions, ed., Ralph Barker, vol. 2 (London, 1700), 420.
} 
providing 'all our quiet and security from Fear and Danger, from the Fraud and Oppression of those who are more Crafty and Powerful than our selves, from endless Confusions and Distractions, and from a State of perpetual Feud and War with all Mankind' - was deduced. ${ }^{18}$

In another sermon preached in the same year Tillotson spoke of the legitimation of royal authority. He believed that royal authority was divine guarantee to the people for true Christianity. Like the kings of Israel royal power had always been exercised by "not only with allowance, but with great approbation and commendation from God himself'. ${ }^{19}$ For him it was obvious that the preservation of true religion was left to the hands of divinely ordained civil authority.

Tillotson went on to discuss the possibility of misgovernment in relation to religious matters. What if the civil magistrate claimed divine right to impose false religion on his people? First of all, Tillotson did not concede to the monarch the right to reject true religion and consequently promulgate false religion. If 'a false religion be established by law', nonetheless, said he, 'the case here is the same as in all other laws that are sinful in the matter of them, but yet made by a lawful authority; in this case the subject is not bound to profess a false religion, but patiently to suffer for the constant profession of the true'. ${ }^{20}$ This was for him how the people stood up against the false religion set up by the civil magistrate.

Gilbert Burnet was another prominent latitude-man who was conscious of the apocalyptic significance of the godly ruler. As shown in the frontispiece of Gilbert Burner's prominent work, the first volume of the History of the Reformation (1679), the King Henry VIII and the Archbishop of Canterbury Thomas Cranmer were portrayed as the political and ecclesiastical leaders who dedicated their lives and capabilities to introducing true reformed religion into England not only under the aegis of divine providence but also in co-operation with parliamentary efforts to confirm the legal justification of the religious reformation. Burnet's illustration of the two Reformation leaders exemplifies the political stance of the latitudinarian clergy. They believed that the true 'catholic' church could not be built up without the protecting role of the civil magistrate. On a basic level, they shared the conventional

\footnotetext{
18 Ibid., 421-22.

19 Tillotson, 'Sermon XXVII: The Protestant Religion Vindicated from the Charge of Singularity and Novelty, Preached before the King at Whitehall, April 2 1680', in Sermons on Several Subjects and Occasions, by the Most Reverend Dr. John Tillotson, Late Archbishop of Canterbury, vol. 2 (London, 1757), 252.

${ }^{20}$ Ibid., 253.
} 
belief in God's providential care for the godly by means of the godly ruler and the biblical and true ecclesiastical institution which would assist the divine plan to realise the heavenly paradise on earth.

After being appointed as professor of Divinity at Glasgow, Burnet had published The Vindication of the Authority, Constitution, and Laws of the Church and State of Scotland in 1673. This work, which was dedicated to Lauderdale, was a defence of the royal prerogative. In the dedication, he wrote that the great rule by which the peace and order of all human societies was maintained was obedience to the Laws, and submission to the Authority of those who God chose to defend and govern the people. ${ }^{21}$ Burnet's famous book, The History of the Reformation, reveals his view on the role of monarchs in accordance with God's design. Continuing the parallel established by earlier Protestants like John Foxe, Burnet depicted the English monarchs as godly princes. As a whole, his narrative emphasised how God's providence brought them to power and employed them as divine instruments, and had used their authority to secure a true Christianity from antichristian attempts to overturn the Church of England and civil government. Starting with an eulogy to English monarchy the History described the works which Protestant rulers of the sixteenth century had done for the Protestantism's sake. In a dedication to Charles II, Burnet praised the role the king's predecessors had played in promoting Protestantism, and defended the royal prerogative from outside encroachment. As Burnet was convinced that the security of true religion was not guaranteed without monarchical power he urged Charles to repeat what the predecessors had done as godly princes and exercise his authority in supporting Christ's true church, the Church of England. ${ }^{22}$

As in Stillingfleet's description of Charles I as the godly king who was unfortunately executed by radical sectarians, Joseph Glanvill employed the theme of martyrdom to sanctify royal authority. He asserted that 'the King's person is said to be God's; Great deliverance giveth He to His King'. According to him, both Scriptures and heathen antiquity supported the divine attribute of kingship. Some biblical texts were used to demonstrate the king's authority was given from God.

${ }^{21}$ Gilbert Burnet, The Vindication of the Authority, Constitution, and Laws of the Church and State of Scotland (Glasgow, 1673); Andrew Kippis and Joseph Towers, eds., Biographia Britannica, or the Lives of the Most Eminent Persons Who Have Flourished in Great-Britain and Ireland, 2 ed., vol. 3 (London, 1784), 23.

${ }^{22}$ Tony Claydon, William III and the Godly Revolution (Cambridge: Cambridge University Press, 1996), 45-6; Burnet, The History of the Reformation of the Church of England, vol. 1 (London, 1679), 1-2. 
There followed his argument:

... Plato calls the King, ... a kind of God among men. And as the name of God is called upon his person, so also is it. ... Then Solomon sate upon the Throne of the Lord as King, instead of David his Father, 1 Chron. xxix. 23. And saith the Queen of Shebe, Blessed be the Lord thy God which delighteth in thee, to set thee on His Throne, 2 Chron. ix. 8. ... The Kings Titles also relate him to God, viz. those of Gods Anointed, and his Servant: The former given even to Saul, 1 Sam. xii. 3. and Cyrus, Isa. xiv. 1. and the later to Nebuchadnezzar, Jer. xxv. 9. The same also Athanasius gives to Constantinus the great Favourer of the Arrians.... The Kings power likewise is from God; there is no power but of God, and the powers that are, ordained of God, saith the Apostle. ${ }^{23}$

Glanvill's detailed account of the divine authority of the godly ruler culminated in the apocalyptic expectation of the glorious occasion. He believed that 'the glorious things are to come, and we must be cast into New Models'. As he was aware of the history of Interregnum, he described the past as the time when loyalty was scourged by rebellion. Fortunately, however, providence 'restored us our Prince and our Government which our sins had deprived us of, to re-establish us upon the sure Foundations of Righteousness and Peace'. ${ }^{24}$ Glanvill's reverence for the English monarch was based upon a couple of themes, martyrology, apocalyptic interpretation of the restoration of the monarchy, and the political ideology of nonresistance.

\subsection{The Glorious Revolution and the Apocalyptic Justification of the Monarch}

The Revolution of 1688-1689 was another opportunity to assert the Anglican apocalyptic justification of the civil magistrate. After William of Orange's landing at Torbay and accession to the throne, the notion of the godly ruler was promoted by Protestant proponents of the Revolution. They consistently represented the Revolution and its outcome as the work of divine providence. The regime change of 1688-89 was for supporters of the new government the confirmation of the English Reformation and the security of the traditional constitution which James II had ruined. Political circumstances during the 1670s and 1680s had triggered a wave of

${ }^{23}$ Joseph Glanvill, 'Sermon III: Christian Loyalty, Preach'd on the King's Martyrdome', in Some Discourses, Sermons and Remains (London, 1681), 154-56.

${ }^{24}$ Ibid., 171-73. 
anti-Catholicism. As the previous chapter shows, Anglicans believed that a series of kings' pro-Catholic activities were weakening the Church of England. ${ }^{25}$ Anti-popery was undeniably linked to apocalyptic language: Roman Catholicism as an antichristian enemy was seducing the monarch and laity to superstition and idolatry. Therefore, the Revolution was providentially momentous because God delivered England from the threat of popery, securing the traditional values of the English monarchy and church. ${ }^{26}$

In particular, God's providence was vital to Burnet's argument, and his argument for it was not superficial. Burnet preached on the last verse of Psalm 107, in which 'he observed the wonderful Providence of God towards them in the whole Conduct of Affairs in this Undertaking, and how they intended to have landed the 4th of November'. ${ }^{27}$ As Tony Claydon argues, his feeling of God's intervention arose by placing the events of 1688 within a history of 'reformation'. In the 23 December sermon, William's invasion was given meaning, not just by God's evident support for the prince's forces, but also by explaining it as part of a process of return to godly purity. The central argument which Burnet made at St James' was that William's invasion had been designed by God. Much of his preaching during the late 1680s was dedicated to a demonstration that the prince of Orange's success had been brought about by God, and that it had proceeded according to some divine plan. By interpreting the history of Reformation, he could find good examples of godly princes protecting Protestantism against Catholicism. ${ }^{28}$ Burnet took the Revolution of 1688-89 to be a turning point in English history in terms of godly ruler making their appearance in accordance with providence.

Drawing on anti-Catholicism, Burnet saw the history of the Reformation as restoring true religion and setting a firm foundation of the reformed church with the help of God's providence. God's chosen prince, at that time, was sent to achieve what God's providence designed. William and Mary's coronation was seen as the best moment of giving 'the last finishings to our Reformation'. His sermon was full of hope with the new monarchs, saying that 'let us meditate a little on this great

\footnotetext{
25 John Spurr, The Post-Reformation: Religion, Politics and Society in Britain, 1603-1714 (Harlow: Longman, 2006), 158-59.

${ }^{26}$ Kathleen Wilson, 'A Dissident Legacy: Eighteenth Century Popular Politics and the Glorious Revolution', in Liberty Secured?: Britain before and after 1688, ed., James Rees Jones (Stanford: Stanford University Press, 1992), 332.

27 Anonymous, The Expedition of His Highness the Prince of Orange for England (London, 1688), 6-7.

${ }^{28}$ Claydon, William III and the Godly Revolution, 32, 45.
} 
Salvation that he has wrought for us, and let us carry it on the those Glorious ends of settling our Religion, and delivering our Nation, not only from all Oppression and Injustice at present, but from the danger of falling under it for the future' ${ }^{29}$

In a sermon preached before William of Orange in 1688, Burnet proclaimed that the Revolution brought 'so many Characters of the Attributes of God' into England, which happened by God's providence. ${ }^{30}$ His apocalyptic idea was prerequisite for the justification of William's interference in English politics. Everything which had happened in this world, he claimed, was God's work.

The whole Springs of Nature are wound up by him, so that all things are in some sort his doing: He gives also a secret Direction to all second Causes to accomplish his Eternal Purposes. ... He also on some great occasions does Violence to Nature, and puts her out of her Channel in those extraordinary Productions that are called Miracles. But besides all these, there are times in which the great Governour of Heaven and Earth will convince the World, that he is not an unconcerned Spectator of Human Affairs. ${ }^{31}$

The examination of God's providence was followed by the necessity of the godly prince to protect the true church. As explained in the previous chapter, an emphasis on return to primitive virtues like purity and simplicity was important in restoring true Christianity. This was a significant part of the tasks the godly magistrate needed to fulfill in cooperation with the church. Burnet's wellacknowledged idea of two-church battle led to the justification of William's invasion. He especially argued that the collapse of James's regime could be explained as providential in terms of his two-church narrative. ${ }^{32}$

In hope of a church settlement, the Anglican celebration of the victory of the Protestant prince turned into even broader expectations of the new godly ruler. Before being ordained as the bishop of Chichester in 1689, Patrick expected that that Wonderful Work which God hath wrought in our days, and before our Eyes, by that great Prince, whose Spirit he hath stirred up to undertake our Deliverance from Popish Tyranny, and whose Proceedings he hath blessed with amazing Success, may well awaken the minds of considering Persons

\footnotetext{
29 Burnet, A Sermon Preached before the House of Commons, on the 31th of January, 1688. Being the Thanks Giving-Day for the Deliverance of This Kingdom from Popery and Arbitrary Power, by His Highness the Prince of Orange's Means (London, 1689), 33-5.

30 Burnet, A Sermon Preached in the Chappel of St. James's, before His Highness the Prince of Orange, the $23 d$ of December, 1688 (London, 1689), 2.

31 Ibid., 3.

32 Ibid., 5.
} 
to expect greater things he is about to do in the World, which groaneth ... to

be delivered into the glorious Liberty of the children of God. ${ }^{33}$

Patrick's appeal to the civil magistrate to work with divine providence to build up true religion and bring peace and unity to his people reveals his strong faith in the power of godly kingship.

Tillotson also emphasised the apocalyptic significance of the victory of the Protestant monarch. In March 1692, Tillotson, appointed as archbishop of Canterbury one year before, put forward apocalyptic praise of God's providence. In a thanksgiving sermon for the victory of the Protestant prince over popery, he said 'let us humbly beseech Almighty God, that he would long preserve to us the invaluable blessing of our two excellent princes; whom the providence of God hath sent amongst us, like two good angels'. ${ }^{34}$ Like other Anglican clergy, he believed that divine providence had not just rescued these two princes but saved the whole nation 'out of Sodom.' He finished the celebration of the Revolution with a blessing for William III and Anne:

May they have a long and happy reign over us, to make us happy, and to lay up in store for themselves a happiness, without measure, and without end, in God's glorious and everlasting kingdom; for his mercies sake in Jesus Christ, to whom with thee, O Father, and the Holy Ghost, be all honour and glory, thanksgiving and praise, both now and for ever. Amen. ${ }^{35}$

This providential idea continued to prevail even in the early eighteenth century. Sharp's admiration of providential care for the prince is seen in the sermon celebrating the coronation of Queen Anne in 1702. 'We ought', said he, 'indeed, to admire God's Goodness to us: Often have we provoked him by our manifold Sins and Impieties ... but yet in his Judgments he hath always remembred Mercy'. He continued to give thanks that divine providence had restored the monarchy and the Church of England and raised up a Protestant monarch to rescue English people from popish dangers. He believed that it was providential work to make him still enjoy the same 'Rights and Liberties, and Properties' under the 'same Government'. ${ }^{36}$

\footnotetext{
33 Simon Patrick, A Sermon Preached in the Chappel of St. James's before His Highness the Prince of Orange, the 20th of January, 1688 (London, 1689), 32.

34 Tillotson, 'Sermon XLI: A Thanksgiving-Sermon for the Late Victory at Sea. Preached before the Queen at Whitehall, March the 20th, 1692', in Sermons on Several Subjects and Occasions, by the Most Reverend Dr. John Tillotson, Late Archbishop of Canterbury, vol. 3 (London, 1757), 185.

${ }^{35}$ Ibid., 186.

${ }^{36}$ Sharp, 'Sermon IV Preached at the Coronation of Queen Anne; in the Abbey-Church at Westminster, on the
} 
The survey of latitudinarians' view of the godly ruler offers sufficient evidence to present their apocalyptic understanding of politics. The latitudinarians' use of apocalyptic themes in their arguments about royal supremacy and godly rule indicates the continuing influence of apocalyptic rhetoric on English Protestants at various levels.

\subsection{The Royal Supremacy Debate}

When discussing the nature of the godly ruler, the relationship between the magistrate and church was controversial. Having reduced papal power to authority jure humano, sixteenth-century Protestants no longer thought that the pope had power over the secular sphere. The English Reformation under Henry VIII repudiated papal power over the English and their church. It was the monarchy, often in tandem with parliament, which now exercised authority over the Church of England. The questions were about the nature, extent and purpose of that authority. The royal supremacy was the key notion at the heart of a long debate over the magistrate's role in religious matters. Competing ideas of religion and politics in the seventeenth-century provided the circumstances for various theories for or against royal supremacy to develop.

The Elizabethan Settlement of 1559 had defined the royal supremacy as 'jurisdictional governance, not sacerdotal powers'. ${ }^{37}$ One of the remarkable Anglican scholars of the late sixteenth century, Richard Hooker, also defended royal supremacy as based upon the principal tenets of orthodox ecclesiology. ${ }^{38}$ Hooker was inclined to see priests as 'overseers and stressed the dependence of churchmen on monarchical authority. ${ }^{39}$ English Protestants were reluctant to distinguish divine ordained bishops from king's authority. From the Reformation, thus, the claim that royal authority was superior to the clerical power over religious external matters became common among English Protestants.

Throughout the seventeenth century, the discourse of the godly monarch was often interwoven with the practical exercise of royal authority. While the apocalyptic

\footnotetext{
23d of April, 1702', 104.

37 Rose, 'The Godly Magistrate', in The Oxford History of Anglicanism, Vol. 1, Reformation and Identity, c.15201662, ed., Anthony Milton, vol. 1 (Oxford: Oxford University Press, 2017), 105-6.

${ }^{38}$ On Hooker's theological attitude towards royal authority over the church, see W. J. T. Kirby, Richard Hooker's Doctrine of the Royal Supremacy (Leiden: E. J. Brill, 1990), chap. 4.

39 Jeffrey R. Collins, 'The Restoration Bishops and the Royal Supremacy', Church History 68, no. 3 (1999): 55051.
} 
images of the godly monarch and the true apostolic church were employed by English Protestants, the relationship between the secular ruler and godly divines opened the way for debate in many forms. How could the relationship between royal authority and divine right episcopacy be clarified? Once it is admitted that the English church was established jure divino, is the claim of jure divino episcopacy compatible with royal authority? In the early seventeenth century, especially, these questions were of importance to William Laud. The Laud continuously sought to buttress the Church of England by arguing for a strong alliance with the king. Charles I, as a devout Anglican, was also willing to leave the determination of the nature of religious matters to Laud. ${ }^{40}$ Laud's attitude towards the king was rooted in the belief that the monarch was God's delegate and protector of the church. In Laud's view, the health of the kingdom demanded the unity of monarchical and religious power and the king could have the unified power. ${ }^{41}$ Laud's claim of the unified order reflected his affirmation of the royal supremacy. This is not to say that Laud did not support jure divino episcopacy. For Laud, as Jeffrey Collins argues, 'jure divino episcopacy was always subordinated to the practical mandates of English Erastianism'. ${ }^{42}$ He insisted that king's authority could not be damaged by priests.

The contest over the royal supremacy grew when political uncertainty gave rise to various issues regarding the monarch-church relations during the Restoration. The traditional discourse of king's authority, inherited by the Reformation and Laudian traditions of the royal supremacy, faced the new political change. It is true that Restoration politics encouraged the restored monarch and the Episcopal Church to exercise the king's supremacy in religious settlement. The English monarch had been deemed to retain 'a large prerogative over the church', and the religious settlement of 1662 reinstated the Church of England as the sole and exclusive national church, even if in reality if faced a number of denominational rivals and encountered opposition from Nonconformist critics. ${ }^{43}$ However, Restoration bishops, in particular, were less eager to buttress king's role in religious matters that previous divines did. They were more committed to defending bishop's authority based upon

\footnotetext{
${ }^{40}$ Mark Goldie, 'Toleration and the Godly Prince in Restoration England', in Liberty, Authority, Formality: Political Ideas and Culture, 1600-1900, eds., John Morrow and Jonathan Scott (Exeter: Imprint Academic, 2008), 13-4, 32-4, 41, 57.

${ }^{41}$ Collins, 'The Restoration Bishops and the Royal Supremacy', 552.

42 Ibid., 554.

${ }^{43}$ Rose, Godly Kingship in Restoration England: The Politics of the Royal Supremacy, 1660-1688, 6.
} 
jure divino theory. ${ }^{44}$

The shift in Anglican political thought partly stemmed from Stuart monarchs' approaches to religious issues. During the reign of Charles II and James II, many worried that the king seemed to fail to settle religious conflicts both between Anglicans and Catholics and between conformists and Nonconformists. At first glance, the political and religious restorations seem to show that policies of Charles II's reign were dominated by royalist and Anglican churchmen, and that Nonconformists were held to be repressed by a series of penal laws. As Mark Goldie shows, however, it is surprising that Charles II sometimes leaned towards dissenters, even Catholics. ${ }^{45}$ Although the parliament struggled to stop his attempts to relax religious impositions upon Nonconformists, the king persistently made conciliatory gestures to dissenters by offering his plans for indulgence in 1662 and 1672. As early as 1660, in fact, the Declaration of Breda which Charles II published before coming to his throne revealed his desire for soothing religious tensions which had led to the violent clashes between Puritans and royalists in earlier decades. Catholics and Dissenters who argued for religious liberty so that they could be allowed to continue their own form of worship placed their hope in the king using his legitimate authority to relieve the suffering imposed by religious regulations. The king was confident in the exercise of royal supremacy over religion. Nevertheless Charles II had failed to act as his belief directed. The disagreements between the king and the parliament, or the church in religious matters provoked disputes over how far the civil ruler could exercise his authority over religious matters, and over the authority of bishops, and the role of royal supremacy in the exercise of godly rule. ${ }^{46}$

James II was also ambitious to exercise the royal prerogative and to do so in ways harmful to the Church of England. The 1687 Declaration of Indulgence was designed to dispense all non-conforming groups including Roman Catholics from the penal laws. The English monarch's attempts to exercise the prerogative power provoked a complicated reaction from the Church of England. In this situation, the choice was between a hostile attitude towards royal interference in practices of religious worship or maintaining a supportive attitude towards the exercise of royal

\footnotetext{
${ }^{44}$ Collins, 'The Restoration Bishops and the Royal Supremacy', 558.

${ }^{45}$ Goldie, 'Danby, the Bishops and the Whigs', in The Politics of Religion in Restoration England, eds., Tim Harris, Paul Seaward, and Mark Goldie (Oxford: Blackwell, 1990), 75.

${ }^{46}$ Goldie, 'Toleration and the Godly Prince in Restoration England', 45-65.
} 
authority to protect an idea of national church. When Anglicans saw the monarch support uniformity to the Church of England, the question of the monarchical role in religion was easy to answer. However, as he seemed less amicable to the Church, Anglicans became more confused about the king's political intentions.

\subsection{The Latitudinarians' Account of Royal Supremacy}

While the majority of conformist authors shared a belief in the apocalyptic importance of the civil ruler, there were distinctions within the Church of England itself. The division of opinions within the Anglican clergy was engendered by the problem of whether ecclesiastical authority was subordinate to civil authority. Anglicans, who supported the royal supremacy, surprisingly opposed civil interference. They often teamed up with Parliament, which were afraid of the royal supremacy encroaching on the authority of Parliament, to reject king's ecclesiastical policies. $^{47}$ Many latitudinarians, however, held different views regarding the royal supremacy. One of the key issues in their understanding of the royal supremacy was the extent to which the civil ruler could determine religious matters. In latitudinarians' view, this issue was involved in adiaphora, or things indifferent.

The latitudinarians' belief in the godly ruler emerged from disputes about the relationship between the royal supremacy and the church. The latitudinarians assented to the Reformation tradition that the church was subordinate to the monarch. However, the civil ruler only had only jurisdiction over external matters in both religion and politics. While the discussion of royal supremacy developed over time, religious leaders like priests and bishops were considered to be ordained by the monarchical grant and expected to play a role as a prophet providing advice to their princes on religious issues, and hence, that clerical authority was subordinate to royal supremacy. ${ }^{48}$ In their minds, clergy had rights to give advice to the secular magistrate on true religion and any doctrinal matter. The proper relationship between the prince and church could be illustrated as an image of the monarch hearing the clergy's advice; the partnership of Moses and Aaron, crown and mitre.

No sooner had Anglicans expected the Anglican superiority to dissenters to be

\footnotetext{
${ }^{47}$ Collins, 'The Restoration Bishops and the Royal Supremacy', 578; Rose, 'Royal Ecclesiastical Supremacy and the Restoration Church', Historical Research 80, no. 209 (2007): 333.

48 Rose, Godly Kingship in Restoration England: The Politics of the Royal Supremacy, 1660-1688, 31-3, 52, 57;

'Kingship and Councel in Early Modern England', The Historical Journal 54, no. 1 (2011): 47-71.
} 
restored through the Restoration settlement than some latitudinarian clergy readily proposed propaganda for the royal supremacy. Stillingfleet's early work, Irenicum (1660), began with answering the question of whether a particular form of church government was established by divine law or whether it was left to the prudence of every church to agree upon the form of government. He wrote that 'the main subject of our present debate will be whether any one particular form of Church Government be settled upon an unalterable divine right'. ${ }^{49}$ His argumentation was made up of two parts: the first was the authority of church government and the second was the role of civil magistrate in religion.

The work aimed to settle a dispute about the church government and the use of power of civil magistrate in religion. For Stillingfleet there was no consensus among the seventeenth-century contemporaries about the form and authority of church government. When he published the first edition of Irenicum in 1660, it was the time when the latitudinarian clergy including Stillingfleet were confronting the problem of political authority in religion and the tension between political impositions and the freedom of the individual conscience. ${ }^{50}$ The question was about who could legitimately impose 'indifferent things' for the sake of order and uniformity. He thought that there had been no satisfactory conclusion achieved about the relationship between the church and state. The more debates over the forms of church government had grown in intensity, the more Stillingfleet felt himself the need to find the one universal way for the settlement over church issues so that the different parties could agree to a common framework.

The fluid political circumstances of the Restoration in which Stillingfleet's work was written provided him with the flexibility to explain his view of the church government. Stillingfleet asserted that the necessity of a form of church government rested upon jure divino. In other words, the ground and reason for the existence of government in the church lay in divine right. However, he continued to argue that the particular form of church government could be different according to the several circumstances of times, places and persons. For him it was clear that God had given men 'power and liberty to determine the form of Church Government', and hence,

\footnotetext{
49 Stillingfleet, Irenicum. A Weapon-Salve for the Churches Wounds, or the Divine Right of Particular Forms of Church-Government (London, 1660), 4.

50 John Marshall, 'The Ecclesiology of the Latitude-Men 1660-1689: Stillingfleet, Tillotson and "Hobbism", The Journal of Ecclesiastical History 36, no. 3 (1985): 409-10.
} 
that one form of government was agreeable in some places did not necessarily mean that the other one was not. He repeatedly wrote that the reason of church government is 'immutable', and 'holds in all times and places', but the particular form of that government was juris divini permissive, to which he added his interpretation that 'both the Laws of God and nature have left it to the Prudence of particular Churches to determine it'. ${ }^{51}$ In short, the ground and reason for the existence of any form of government in the church is unalterable by divine right, but the particular form of it could be different according to the several circumstances of times, places and persons. He argued this by saying 'modus observantis differed, but the ratio praecepti was immutable'. ${ }^{5}$

One of controversial issues Stillingfeet raised was his rejection of an argument that the episcopal government was founded upon the unalterable divine right. The decision of the form of the church government must be left to the prudence of every particular Church, consisting of many Congregations, to agree upon its own form which it judgeth most conducing to the end of Government in that particular Church'. ${ }^{53}$ For him prudence needed to be used to achieve the peace and stability of the church. Besides he laid down some general principles for the church government:

The first principle is, That Prudence must be used in settling the Government of the Church. This hath been the whole design of this Treatise, to prove that the Form of Church Government is a meer matter of prudence, regulated by the Word of God. ... The second principle is, That Form of Government is the best according to principles of Christian Prudence, which comes the nearest to Apostolical practice, ... Lastly, What Form of Government is determined by lawful authority in the Church of God, ought so far to be submitted to, as it contains nothing repugnant to the word of God. So that ... it remains that the determining of the Form of Government is a matter of liberty in the Church; and what is so, may be determined by lawful authority; ... 54

Now Stillingfleet turned his argument into an examination of whether any particular form of the church was designed by God's law which bound all the people

\footnotetext{
51 Stillingfleet, Irenicum. A Weapon-Salve for the Churches Wounds, or the Divine Right of Particular Forms of Church-Government, 9-10.

${ }_{52}$ Ibid., 11.

53 Ibid., 171.

54 Ibid., 416-18.
} 
to the observance of things the law determined. A controversy about what was most apostolic institution between 'a Colledge of Presbyters' and 'Antonomasie called Episcopacy' was clearly insignificant. In his view, what mattered was that 'the Church of Christ is left to its own liberty for the choice of its form of Government, whether by an equality of power in some persons, or superiority and subordination of one order to another'. ${ }^{55}$ One of the most reliable reasons was simple: the Scriptures did not stipulate the form of church government but left this issue to human decision. What the Scriptures did not command was the matter 'accidental and circumstantial' and 'a matter of Christian liberty'. He did not proceed to enquire why the Bible did not so. For him it was a significant fact that 'if no such thing be made appear, the thing remains a matter of liberty, and so the Scriptures perfection as to necessaries in order to salvation, is no ways impeached by it. ${ }^{56}$

Stillingfleet confronted the further question concerning the problem of prudence: who had prudence to decide on the form of church government? The discussion of the church government was followed by a consideration of the role of civil magistrates. Stillingfleet thought that where the form of church government could be determined by the positive laws, the authority of civil magistrate could play a significant role. Although the civil rulers had no proper power over religion itself, he argued, the 'supreme Magistrate is bound by virtue of his office and authority, not only to defend and protect it, but also restrain men from acting any thing publickely tending to the subversion of it'. It is true that Stillingfleet admitted the liberty of conscience should be protected, but he thought that it could not limit the magistrate's power because the liberty of conscience was synonymous with the "the liberty of mens judgements', not the liberty of practice over which the civil magistrate could preside. ${ }^{57}$ Stillingfleet used the biblical example of the use of idolatry by writing that the pervasive use of idolatry illustrated in Micah was caused by the absence of kingship in Israel. The godly ruler, therefore, was useful for preserving a society. A question represents his call for the godly ruler in Christendom: 'were it not for this power of Magistrates under the Gospel, how could that promise be ever made good, that Kings shall be nursing Fathers to the Church of God? ${ }^{58}$

\footnotetext{
55 Ibid., 175.

${ }^{56}$ Ibid., 199.

57 Ibid., 39-40.

58 Ibid., 40.
} 
The idea of state-run religion was based upon the distinction between internal and external powers. These two kinds of powers were also respectively called an internal and formal power and an external and objective power in his explanation. For Stillingfleet internal power simply referred to powers of 'things within and without the Church'. With regard to things in the church, he argued, the internal power lay in the exercise of the ministerial function such as preaching God's words and administering the sacrament while the external power was concerned with the defence, and protection of true religion. He made it clear that the former was proper to 'the Ministry', the latter to 'the Supream Magistracy'. Even though the magistrate did not have power about religion itself, he [or she] was required to take care of the church. This caring image of rulers was easily borrowed and supported from the biblical examples like king Uzzias. ${ }^{59} \mathrm{He}$ emphasised the difference between the church and the commonwealth: they were constituted for each ends, one for political, the other spiritual:

One temporal, the other eternal; they subsist by different Charters; the one given to men as men, the other to men as Christians; They act upon different principles, the one to preserve civil rights, the other to promote an eternal interest. $^{60}$

This argument implied that the roles of the civil magistrate and priests were different: the civil magistrate had no power to excommunicate the people out of the church, nor did priests have power to cast anyone out of the country. It was clear to Stillingfleet that the church was a society distinct from civil government because of a different purpose of establishment. Where the subordination of a religious society to secular authority was required in a country, excommunication was the greatest penalty the church was permitted to impose upon its lay members.

Edward Fowler shared Stillingfleet's view of the relationship between the state and religion. In his defence of the latitudinarian ecclesiological view, Fowler made it abundantly clear that the latitudinarians did not oppose episcopacy. Seeing that they were accused of undermining episcopacy, Fowler replied that they did not refute the Episcopal Church but approved of it because 'it is apparent that so much as is essential' to ecclesiastical government and it did 'universally take place in the

\footnotetext{
59 Ibid., 41-2.

60 Ibid., 192.
} 
Church presently after the Apostles times'. ${ }^{61}$ He made use of Chillingworth's argument to vouch for his opinion. According to Chillingworth, he wrote,

If we abstract from Episcopal Government all Accidentals, and consider onely what is essential and necessary to it; We shall find in it no more than this: An appointment of one man of eminent Sanctity, and Sufficiency to have the care of all the Churches, within a certain Precinct or Diocese; and furnishing him with Authority ... to the intent that all the Churches under him may be provided of good and able Pastors: and that both of Pastors and People conformity to Laws, and performance of their duties may be required, under Penalties, not left to discretion, but by Law appointed. ${ }^{62}$

Fowler's citing of Chillingworth shows that he did not refuse the claim for Episcopalian church government. Even though he thought episcopacy was essential to church government, yet he did not accept the separation of ecclesiastical and secular authority: the civil magistrate had power to decide all forms of worship that were called indifferent things. For him the authority of the Episcopal Church was 'not absolute or arbitrary but regulated and bounded by Laws, and moderated'. ${ }^{63}$ This view was distinct from those who supported the jure divino episcopacy. Fowler's work represented a series of key theological principles of latitudinarian Anglicans.

Latitudinarian divines were keen to insist on limiting the freedom of individual conscience to the realm of private faith. In vindicating major controversial aspects in the theology of the latitudinarians, Fowler clearly posited that the latitudinarians believed 'the Civil Magistrate to have a Power, both Legislative and Judiciary, as well in Sacred, as in Civil Affairs'. ${ }^{64}$ Fowler went on to mention the scriptural examples upon which their opinion of the authority of the civil magistrate rested. It is apparent, for him, that

In the first Institution of Priesthood, Moses took away no part of the Supream Jurisdiction from the Politick Authority; for he, as King of Jesurun[Jeshurun], was constituted by God himself the Keeper, as well of both Trumpets, as Tables. As Moses, not Aaron, delivered the Ceremonial Law; so long after Moses, King David, instituted the Courses of Priests, and

\footnotetext{
${ }^{61}$ Edward Fowler, The Principles and Practices of Certain Moderate Divines of the Church of England (London, $1670), 322-23$

62 Ibid., 323-24.

63 Ibid., 324.

64 Ibid., 325.
} 
Solomon thrust out Abiathar the High Priest. And when Christ inaugurated his Apostles ... he detracted nothing from the Authority of the Civil Power. ${ }^{65}$

Fowler continued to deal with the latitudinarians' opinion as to the authority of church government. As Christ bestowed great power upon apostles, it was in the hands of the church governor to 'Compose Forms of Prayer to be used in Publick; and such Rites as they in their Wisdom shall conceive most proper for the decent, orderly and Reverend Solemnizing of Divine Worship' ${ }^{66}$

Fowler was aware of the criticism that latitudinarian thinking about the authority of civil and ecclesiastical government was a threat to religion. ${ }^{67}$ Fowler warned about the opposition to the royal supremacy in religious affairs. He argued that if individual churches had liberty to decide the form of the government, it would have resulted in 'the invalidating of all Laws, and utter subversion of Government' ${ }^{68}$

Fowler's argument was later echoed in Burnet's legitimation of the authority of civil government in religious matters. Burnet published a translation of Lactantius' Latin work, A Relation of the Death of the Primitive Persecutors (1687). Burnet wanted to indicate that all Christians were obliged to subordinate themselves to their civil ruler, as the early Christian author had argued. Lactantius's underlying proposition was that human society could be preserved by social virtues. As those living within Christendom, for him, were necessarily Christians and the 'members of the State of Kingdom' to which they belonged, the corollary was that Christian subjects were bound to obey the law of society. In introducing the Ancient Father's thought, Burnet was intent to show that everyone in society need to be aware of that they were the subjects of a civil government since they held their temporary estates and liberty. For Burnet, God's kingdom was not of this world so Christianity could not replace the law of secular society. ${ }^{69}$ In Burnet's argument, Lactantius' words revealed that all secular matters were in the hands of the civil magistrate.

While asserting that there could be no authority over human conscience but Christ in matters concerning faith, Burnet thought that 'things indifferent' were subject to the determination of the church authority. In one of his major apocalyptic

${ }^{65}$ Ibid., 325-26.

${ }^{66}$ Ibid., $327-28$.

${ }^{67}$ Goldie, 'John Locke, Jonas Proast and Religious Toleration 1688-1692', in The Church of England, c.1689c.1833: From Toleration to Tractarianism, eds., John Walsh, Colin Haydon, and Stephen Taylor (Cambridge: Cambridge University Press, 1993), 154.

${ }^{68}$ Fowler, The Principles and Practices of Certain Moderate Divines of the Church of England, 330.

69 Burnet, A Relation of the Death of the Primitive Persecuters (Amsterdam, 1687), 19-20. 
works, The Mystery of Iniquity Unvailed (1673), Burnet claimed that Christ left 'things indifferent' to be determined by 'a power with his Church'. He thought that ministerial authority was derived from Christ so it was reasonable to affirm that rituals and matters that were 'external and indifferent' needed to be set up by the church. In addition to this, Burnet mentioned of the duty of obedience to the legislative government. 'We also hold', he added, 'that the Civil Powers are of Christ, whose Gospel binds the duty of obedience to them more closely on us'. In his opinion, more importantly, the civil authority could not be resisted by the subjects, even when it did wrong. The judgement of the civil government must be left to 'Christ's Tribunal' which set it up, and the people did not have rights to resist the godly authority. ${ }^{70}$ This recommendation of passive suffering was shared by Burnet's conformist friends.

The duty of obeying royal authority was one of the main emphases of these Anglican divines throughout the Restoration period. Even during the reign of the Catholic King James II, they delivered a series of sermons insisting on the connection between the biblical justification of the kingship and divine right of monarchy. Fowler was convinced of the divine right of monarchy as he thought God gave his power to the secular monarch. As he found that 'By me Kings Reign, and Princes decree Justice; by me Princes Rule, and Nobles, even all the Judges of the Earth' in Proverb 8.15., the authority of the civil magistrate was built on the biblical foundation. As God's vicegerent, the king was conceived to be anointed by God. Fowler even claimed that pagan kings also were anointed by God. ${ }^{71}$ For Fowler, a series of biblical examples plainly implied that 'Honour or Reverence is due to all Men.' In his discussion of this duty, he intended to encourage readers to obey him if they were obeying God.

Fowler stressed the religious foundation on which civil authority was secured. He claimed that everyone was obliged to obey the king simply because 'God hath commanded him, who makes no Conscience of living in disobedience to Gods own Laws.' Only those who did not fear God and divine commandments would break the king's laws. Thus, for Fowler, the religious virtue of 'Fear of God' was essential to

\footnotetext{
${ }^{70}$ Burnet, The Mystery of Iniquity Unveiled in a Discourse, Wherein Is Held Forth the Opposition of the Doctrine, Worship, and Practices of the Roman Church (London, 1673), 152-53.

${ }^{71}$ Fowler, A Sermon Preached at the General Meeting of Gloucestershire-Men; for the Most Part Inhabitants of the City of London: In the Church of St. Mary Le-Bow, December the 9th 1684 (London, 1685), 6.
} 
the preservation of royal authority. ${ }^{72}$

Glanvill undertook a close exploration of the divine authority of the civil magistrate in relation to civil obedience to the godly king. Asserting that 'Kings wear Gods Image and Authority', he concluded that resistance 'affronts the authority of God, with which Kings are invested' for nobody could have power to disobey the 'Vice-Roy' into whose hands God put legitimate authority to govern the subjects. ${ }^{73}$ Glanvill's next step was to insist on the principle of non-resistance to the government and rehearse the discourse of duty to the civil magistrate. 'We should obey', said he, 'those that have the rule over us; submit to every ordinance of man; pray for Kings and all in authority; submit to Principles and Powers, and to obey Magistrates'. ${ }^{74}$ If resistance overcame the supreme power, he warned, 'all the evils will follow, which usually do upon Competitions and variety of Claims, which will breed everlasting disturbance, and eternal fears'. In sum, the destruction of legitimate authority would open the way to 'anarchy and Disorder'. ${ }^{75}$

The detailed examination of a wide range of the moderate Anglican divines' literary outputs has indicated that most of the previously-mentioned latitudinarians like Stillingfleet, Tillotson, Burnet, and Fowler took it for granted that practical matters, except for things over which clergy had religious jurisdiction, such as preaching and teaching core Christian principles and God's word to the laity, were subject to monarchical determination. It is evident, thus, that the discretion of priests over punishment in the church was limited to excommunication which they could inflict upon the church members. The latitudinarians thought that even if a prince imposed a false religion upon the people, they could not resist. Their only option was to suffer patiently for professing the true religion. This was usually referred to as a doctrine of 'passive resistance'.

\subsection{The Charge of Erastianism against the Latitudinarians}

Now we should consider the latitudinarians' attitudes towards royal supremacy in connection with their alleged 'Erastianism'. It seems obvious that after the Restoration these moderate clergy consistently insisted upon the royal supremacy by

\footnotetext{
72 Ibid., 14-5.

73 Glanvill, 'Sermon III: Christian Loyalty, Preach'd on the King's Martyrdome', 156-57.

${ }^{74}$ Ibid., 158.

75 Ibid., 163-64.
} 
arguing that the church's submission to the monarch was inevitable. The allegation that these moderate conformists proclaimed Erastianism was made by their adversaries, and has come under scrutiny from many historians. ${ }^{76}$ The interest in the debate about Erastianism ran high during the late seventeenth century and early eighteenth century. This issue has caught many historians' attention. Modern scholarship has made much of the alleged similarities between the moderate Anglicans and Hobbes' approach to religion and authority. John Marshall points out that the accusation of 'Hobbism' against the latitudinarian clergy was made both by the High Church apologists and Nonconformists. According to him, the High Church opponents like Simon Lowth and Nonconformists including Richard Baxter, John Humfrey and others claimed 'theocratic doctrines in common', so it was logical for them to deem the latitudinarians as Erastian. Marshall argues that moderate Anglicans, remarkably Stillingfleet and Tillotson, wrote works which 'evinced distinctively Erastian positions' during the Restoration period. ${ }^{77}$ The latitudinarians were accused of 'Hobbism' since their opponents identified Erastian arguments with the discourse of church government and the authority of the civil magistrate in their works.

It is contended that the latitudinarians displayed an Erastian perception of the relationship between religion and politics. Facing pressing issues like comprehension and toleration imposed by Stuart monarchs, the latitudinarian clergy involved themselves with the dispute about the monarch's control over religious matters. Historians have discussed the latitudinarians' account of magisterial authority. Jon Parkin's work analyses the intellectual link between Hobbism and the Latitudinarians' theology. According to Parkin, some latitudinarians such as Stillingfleet and Tillotson were subject to criticism for their Erastian account of the magistrates deciding upon the form of church government. ${ }^{78}$ It had long been that the latitude men were suspected of insinuating the rhetoric of Hobbism or Erastianism by their

\footnotetext{
${ }^{76}$ For more detailed studies see Collins, 'The Restoration Bishops and the Royal Supremacy', 549-80; J. A. I. Champion, The Pillars of Priestcraft Shaken: The Church of England and Its Enemies, 1660-1730 (Cambridge: Cambridge University Press, 1992); John. Spurr, The Restoration Church of England, 1646-1689 (New Haven: Yale University Press, 1991), chap. 3; Rose, Godly Kingship in Restoration England: The Politics of the Royal Supremacy, 1660-1688; Claydon, William III and the Godly Revolution.; Samuel I. Mintz, The Hunting of Leviathan: Seventeenth-Century Reactions to the Materialism and Moral Philosophy of Thomas Hobbes (Cambridge: Cambridge University Press, 1962).

77 Marshall, 'The Ecclesiology of the Latitude-Men 1660-1689: Stillingfleet, Tillotson and "Hobbism"', 408-9.

78 Jon Parkin, Taming the Leviathan: The Reception of the Political and Religious Ideas of Thomas Hobbes in England, 1640-1700 (Cambridge: Cambridge University Press, 2007), 208.
} 
nonconformist or Catholic counterparts. For example, Edward Stillingfleet, says Parkin, was deemed to be a theologian who promulgated 'Leviathan-style' arguments. In the first edition of Irenicum (1660), Stillingfleet used natural law theory to provide a more suitable explanation as to which form of church government was jure divino. In short, Stillingfleet's argument implied that the dispute over the appropriate church government and other external matters of worship should be decided in accordance with magistrate's will. Parkin says that Stillingfleet tried to avoid accusations of Hobbism by, for example, offering a different characterization of the state of nature from Hobbes' version of it, but he consequently demonstrated that he was advancing a 'super-Erastian' argument that civil magistrates had the right to determine the explicit form of church government as Hobbes had similarly argued. ${ }^{79}$ Parkin has provided further examples of other latitudinarians to demonstrate that their views of the church and state were not much different from those of Hobbes. Among them, Stillingfleet and Tillotson were remarkable in that they emphasised the power of the civil magistrate to impose an appropriate manner of religion. ${ }^{80}$

Unlike Parkin, Jacqueline Rose doubts the current mainstream opinion that Anglican political thought was nothing more than 'Erastian'. Her book, therefore, aims to show that Anglican attitudes towards the royal supremacy over religion had not been consistent since the Reformation but changed, and that Anglican clergy tried to model themselves on prophets who admonished the civil rulers in order to preserve true religion. ${ }^{81}$ For Rose, this doctrine of a state-run church was deemed dangerous to those who supported jure divino episcopacy, and some Anglicans easily linked the term latitudinarian to Erastianism or Hobbism. She goes on to argue that while Stillingfleet and Tillotson's early thought rejected divine right episcopacy and left the government of the church to the state, during the 1670s and 1680s Stillingfleet changed his opinion and believed that 'the church could be defended against kings, even before he shifted his views of episcopacy in response to Dissenting threats, ${ }^{82}$

Despite all these historians' prominent scholarship on the implications of the latitudinarians' political ideas, it still remains to be examined whether the

\footnotetext{
79 Ibid., 207-8.

${ }^{80}$ Ibid., 358.

${ }^{81}$ Rose, Godly Kingship in Restoration England: The Politics of the Royal Supremacy, 1660-1688, 6, 17.

82 Ibid., 141-48.
} 
latitudinarians' leaning to the supreme power of civil magistrate would be simply considered as motivated by Erastianism. The classification of latitudinarians' thought on kingship as Erastianism due to their praise of the royal intervention in religious affairs overlooks various other motives for their insistence on the royal supremacy. The reasons for such political theology in the late seventeenth-century were manifold. Their apocalyptic belief in the godly ruler was another basis of their support of the royal supremacy. This means that their consistent inclination towards the apocalyptic tradition was manifest in their defence of the royal supremacy. The latitudinarian arguments of the royal supremacy and royal jurisdiction over 'indifferent things' in religion were not unique, but were based on an understanding of the godly ruler which they held in common with other conformist polemicists.

However, the latitudinarians were frequently criticized for vindicating Erastianism or supposedly following Hobbesian thought on the superiority of civil authority over the church. What were the sources of this criticism? In part, the accusation of Erastianism stemmed from the hostility of other Anglican clergy, especially those being educated and indoctrinated as 'High Church' clergymen within the Restoration universities. There was, for example, an intellectual and political backlash against the latitudinarians among the dons at Cambridge. ${ }^{83}$ Criticism and controversy naturally provoked each side to re-assert their position and to clarify the terms of debate. Edward Fowler's defence of the theological traits of the latitudinarians helpfully reveals the main charges of their contemporary critics. By the term, 'latitudinarians', contemporaries meant 'a Gentleman of a wide swallow' which implied that they would accept authority and impositions in order to keep their livings and ministry. Along with this disparaging term, there was an insinuation that their theology was directly or indirectly influenced by Hobbes. For example, Fowler mentioned Hobbes' claim that 'all Moral righteousness is founded in the law of the Civil Magistrate', and that 'whatsoever Magistrates command, their Subjects are bound to submit to, notwithstanding contrary to Divine Moral laws'. The opponents who saw the monarchy as the sacred but not priestly agent recognised these latitudinarians' use of Hobbes' arguments as an evidence that their methodology was

83 J. Gascoigne, 'Politics, Patronage and Newtonianism: The Cambridge Example', Historical Journal 27, no. 1 (1984): 4-5. 
similar to Hobbes'. 84

High Churchmen and later non-jurors, such as Simon Lowth, George Hickes and Charles Leslie, were the most influential critics of latitudinarian political thought. ${ }^{85}$ They also suspected that latitudinarian divines offered a Christianized version of Hobbes. Exemplifying this accusation is Simon Lowth's attack on Tillotson. In his work, Of the Subject of the Church Power in 1685, Lowth criticised Tillotson's sermon by mentioning that 'the Dean of Canterbury takes but a little pains to run over that train of absurdities collected out of Mr. Hobbs ... and compared them with that passage of the Sermon but there was 'little difference in the expression and delivery' between two authors. Lowth claimed that he found Tillotson's positions very close to what Hobbes had said. ${ }^{86}$ Charles Leslie, like Lowth, wrote that Tillotson's sermons 'are all the genuine effects of Hobbism, which loosens the notions of religion, take from it all that is spiritual, ridicules whatever is called supernatural ... His politics are Leviathan, and his religion is Latitudinarian. ${ }^{87}$ These non-jurors saw the elevations of the latitude men to bishoprics after the Revolution - Edward Stillingfleet, Simon Patrick and Gilbert Burnet were appointed to the episcopate in 1689, and John Tillotson and Edward Fowler became bishops in 1691 - as a disaster.

Not only did Anglican rivals attack them but the same criticism was targeted against them by Nonconformists like Richard Baxter, and John Howe. ${ }^{88}$ As to the issue of the extent to which religious toleration would be permitted, in particular, Nonconformist preachers noted the affinity between the latitudinarian conformists' claim for the limit of freedom of individual faith and Hobbes' main point in Leviathan. ${ }^{89}$ Both attacks from the High-churchmen and Nonconformist polemicists were commonly directed to the view of the latitudinarians on the right of the civil rulers to control religious matters. This opposition remained unabated even after

\footnotetext{
${ }^{84}$ Ibid., 13.

85 Even though identifying groups with specific terms is often helpful to demarcate their characteristics, some historians argue that the label of 'High Church' to theologians who supported the independence of the church from royal authority before the Revolution is an anachronism. See Brent S. Sirota, The Christian Monitors: The Church of England and the Age of Benevolence, 1680-1730 (New Haven: Yale University Press, 2014), 23; William J. Bulman, 'Constantine's Enlightenment: Culture and Religious Politics in the Early British Empire, C. 1648-1710' (Ph.D dissertation, Princeton University, 2009), 339-40.

86 Simon Lowth, Of the Subjects of Church Power (London, 1685), 380-81.

87 Parkin, Taming the Leviathan: The Reception of the Political and Religious Ideas of Thomas Hobbes in England, 1640-1700, 388-90.

${ }_{88}$ Marshall, 'The Ecclesiology of the Latitude-Men 1660-1689: Stillingfleet, Tillotson and "Hobbism"', 408.

89 Patrick Müller, Latitudinarianism and Didacticism in Eighteenth-Century Literature: Moral Theology in Fielding, Sterne, and Goldsmith (Frankfurt am Main: Peter Lang, 2009), 37.
} 
several bishops were succeeded by the latitudinarian clergy under the Williamite reign. Replacing predecessors who were ejected from their bishoprics for refusing to take the oath of allegiance to the new regime, the latitudinarian bishops hoped to commit themselves to counselling and supporting the king's religious policy. The High-churchmen questioned the newly ordained bishops' assistance with or, at least, connivance at William III's religious scheme of toleration. When Francis Atterbury's Letter to a Convocation Man Concerning the Rights, Powers, and Priviledges of that Body, written in 1697, expressed openly his worry about 'Heresies of all kinds', he made it clear that there was 'an universal Conspiracy amongst a sort of Men, under the Style of Deists, Socinians, Latitudinarians, Deniers of Mysteries, and pretending Explainers of them, to undermine and overthrow the Catholick Faith' ${ }^{90}$ Atterbury, in particular, launched an attack on Burnet whose two-volume History of the Reformation caught many contemporaries' attention. Atterbury was interested in Burnet's book because he thought Burnet insinuated his Erastian idea of English church history into the work. ${ }^{91}$ Another High-churchman George Hickes complained to Sharp that the latitudinarians were 'as free as the happy liberty of Obeying any Regnant Powers' so they were acting as if they did not concerned about 'what the King be, lawful or unlawful, real or titular, rightful or wrongful, provided he be in Possession of the Throne'. ${ }^{92}$

It seems true that the latitudinarians supported Erastianism in that they did not admit jure divino episcopacy but left the form of church government to the civil magistrate's determination, as Stillingfleet's Irenicum demonstrated. In fact, Stillingfleet argued that the church government was buttressed by the natural law which God laid down, but the form of church government could vary in accordance with times and places. His opinion of episcopacy can be seen as sympathetic to 'reduced episcopacy'. It was plausible that Stillingfleet's episcopacy would seem, to some extent, to tally with Archbishop James Usher of Armagh's suggestion of mixed episcopacy between episcopal and Presbyterian government. ${ }^{93}$ However, in Irenicum at least, Stillingfleet did not regard the primitive tradition of episcopacy as a sole

\footnotetext{
${ }^{90}$ Francis Atterbury, A Letter to a Convocation Man Concerning the Rights, Powers, and Priviledges of That Body (London, 1697), 5-6.

${ }^{91}$ Martin Greig, 'Heresy Hunt: Gilbert Burnet and the Convocation Controversy of 1701', Historical Journal 37, no. 3 (1994): 576, 83.

92 George Hickes, An Apology for the New Separation (London, 1691), 3-4.

93 Spurr, The Restoration Church of England, 1646-1689, 144.; cf. James Ussher, The Reduction of Episcopacy into the Form of Synodical Government (London, 1656).
} 
basis of the church government. He had found "nothing determining the necessity of any one Form of Government in the several Laws of Nature and Christ, nor in the practice of Apostles, or Primitive Church'. ${ }^{94}$ Moreover, his argument for the convenience of the form of church could risk a huge backlash from polemicists supporting the jure divino episcopacy - this is what happened to Stillingfleet. He had plainly argued that if the king had divine and supreme power, it did not mean that the monarch was not absolute over all matters. Rather he added that 'the Magistrate hath no power to excommunicate formally out of the Church any more than to admit into it, nor have Church-officers any power to cast men out of the Commonwealth' ${ }^{95}$ From this point of view, Stillingfleet argued that punishment in the church should be distinguished from civil punishment. He acknowledged a subordination of religious society to the 'Supream authority in the Commonwealth', and asserted that the rules concerning the government of a religious society 'must have their sanction from thence'. 96

The question then arose of how the law of nature vouched for the church government. Stillingfleet laid down two propositions: the first was that there must be a society for gathering together to worship God. And the second was that this society must be governed, preserved, and maintained in a most convenient manner. ${ }^{97}$ For him nature indicated to the people that 'there must be some society for the worship of God'. It seems that Stillingfleet did not deny that men were inclined to enter into a society for either fear or profit. He seemingly accepted these two things would be the main inducements to the formation of a society. Nevertheless, he thought that men's inclination to make a society was invigorated not just by human fear from nature or profit, but by their inherent nature to gather together. In this sense, Stillingfleet's understanding of human's motive for making a society was different from Hobbesian version in that he assured that men 'loves to herd it self with those of his own kind' was inherent in human nature. Furthermore, religion was to be a great improvement of men's sociable nature. ${ }^{98}$

The accusation that latitudinarian political ideology resembled Hobbism does

\footnotetext{
${ }^{94}$ Stillingfleet, Irenicum. A Weapon-Salve for the Churches Wounds, or the Divine Right of Particular Forms of Church-Government, 385.

95 Ibid., 193.

96 Ibid., 143.

97 Ibid., 72.

98 Ibid., 82.
} 
not prove that there was a connection between the latitudinarians and Hobbes. Given that many latitudinarian clergy showed their sympathy to 'Erastian' thought, it is easy to agree with seventeenth-century contemporaries' valuation of them as being imbued with Hobbesian theory. It is difficult to ascertain, however, whether their theological traits were simply a product of Hobbes' influence. In their political thought, in sum, ideas of Hobbes were 'adapted rather than simply or covertly followed'. ${ }^{99}$ Latitudinarians themselves recognised the problematic implications in Hobbes. They were eager to vindicate themselves by claiming their support for the doctrines and liturgy of the Church of England. No sooner did some defences of the latitudinarians emerge than the Church of England regained its previous position. In retrospect, Burnet wrote how they reacted to Hobbist social theory in his lengthy work, History of His Own Time. In contrast to those who accepted the 'impiety' of Hobbes' principles,

This set of men at Cambridge studied to assert, and examine the principles of religion and morality on clear grounds, and in a philosophical method. ...

They loved the constitution of the Church, and the Liturgy, and could well live under them. ${ }^{100}$

What differentiated them from other Anglican divines, stated Burnet, was that they admitted the possibility of variety of institutional forms. He added

They did not think it unlawful to live under another form. They wished that things might have been carried with more moderation. And they continued to keep a good correspondence with those who had differed from them in opinion, and allowed a great freedom both in philosophy and in divinity:From whence they were called men of Latitude. ... their ememies called them Socinians. ${ }^{101}$

For these moderate divines it was evident that they subscribed to the argument that the form and liturgy in the Church of England was the best. However, they differed from their critics in that the form of church government was not set by perpetual divine law but by tradition and customs that were settled by primitive apostles. It is fitting that the contemporary charge of Erastianism, Socinianism or

\footnotetext{
99 Parkin, 'Taming the Leviathan: Reading Hobbes in Seventeenth-Century Europe', in Early Modern Natural Law Theories: Contexts and Strategies in the Early Enlightenment, eds., T. J. Hochstrasser and Peter Schröder (Dordrecht: Kluwer Academic, 2003), 39.

100 Burnet, Bishop Burnet's History of His Own Time, 1:216-17.

101 Ibid., 217.
} 
Hobbism against the latitudinarians should be understood along with their call for the role of godly ruler in settling religious divisions between denominations.

\subsection{The Godly Ruler's Primary Duty: Religious Unity}

The latitudinarians' support of the royal supremacy over the church was associated with their desire for religious unity. Fearful of popery and schism, the latitudinarians were concerned with religious unity. For Anglicans, unity meant, in general, political unity under the monarchy and religious unity under the dominance of the Church of England legalized by religious settlements, such as the Act of Uniformity in 1662. Anglican churchmen consistently felt the demand of civil authority powerful enough to protect true religion from dissenting schism.

The godly prince, hence, not only needed to protect true religion. The latitudinarians thought that the danger of dissenting schism and Catholicism inevitably encouraged the civil magistrate to keep unity by legislating penal laws against other religious denominations. The anti-Catholic sentiment warned those who demanded all subjects to submit to civil authority of the dangers of Catholicism like papal usurpation. In the wake of the Popish Plot (1678) and the Exclusion crisis (1679-1681), anti-Catholicism dominated Restoration politics again. James' Declaration of Indulgence in 1687 fuelled the fear of popery among many conformists. In this time, it was not surprising that Anglicans wrote sermons and discourses to exhort the monarch to promote true Protestant religion and suppress tyrannical and idolatrous Roman faith.

Schism was believed to destroy both society and religion. The latitudinarians accused dissident groups of invoking schism. In a greater or less degree, the Anglican Protestants were hostile to Nonconformists' ideas of religious toleration and liberty of conscience. ${ }^{102}$ They thought that these dissenting arguments would damage the safety of religious unity under the Church of England. Moreover, Anglicans were anxious that Nonconformists' desire for toleration would be realized with the help of Stuart monarchs' conciliatory policies. ${ }^{103}$

The latitudinarian response to schism was seen in Patrick's works. After the fall of Clarendon, there was hope that persecution against Nonconformists would be

\footnotetext{
102 Johnston, Revelation Restored: The Apocalypse in Later Seventeenth-Century England, 135.

103 Spurr, The Restoration Church of England, 1646-1689, 61-2, 68.
} 
relaxed. He immediately reacted to this siguation. In his friendly debate betwixt two neighbours (1668-70), Patrick was heavily concerned by the connection between religious separatism and political dissent, demanding that dissenters should submit to the church as established by the magistrate. His claim was based on the latitudinarian natural law argument that the generality of God's explicit prescriptions about religious worship required the details to be determined by the state. Obedience was essential 'or ... there will be nothing else but confusion'. ${ }^{104} \mathrm{He}$ described dissenters as 'setting up their fancies in all the world' in their own ways to impose their 'forwardness and violence' on others. Therefore he urged them not to set high value on their 'Models and Draughts of Government', but to be 'content to obey rather than rule'. ${ }^{105}$

By the late 1680s, the Anglican mistrust of dissenters had deepened as they saw London dissenters thank James II for offering religious toleration. Notwithstanding dissenting groups appeared to accept James' offer for the purpose of maintaining their liberty of conscience in a pure sense, their cordial response to James's policy seemed to conformists to deserve condemnation. More radical dissenters like Independents, Baptists, and Quakers who were dissatisfied with Presbyterian reaction to religious toleration welcomed the Declaration with enthusiasm. ${ }^{106}$ There were moderate Presbyterians, such as Baxter, who was so suspicious of James' political initiatives that he was not grateful to the king. Leading Anglican divines, nevertheless, thought that Nonconformists drew on a shared desire of religious freedom in common. ${ }^{107}$

Anglican apologists additionally asserted that there was a difference between the Anglican separation from Rome and the nonconformist argument for schism. Anglican apologetics stressed that the Church of England was divided as a national church, but dissenting denominations were trying to withdraw as individuals from the national church. ${ }^{108}$ The Anglican case developed against Rome and dissenters was based on the idea of a national church, an episcopal church.

Anglican preoccupation with anti-Catholicism and opposition to schism led to

\footnotetext{
${ }^{104}$ Simon Patrick, A Continuation of the Friendly Debate by the Same Author (London1669), 421-22.

105 Patrick, A Friendly Debate Betwixt Two Neighbours (1668), 234-35.

106 Goldie, 'Toleration and the Godly Prince in Restoration England', 63.

107 Gary S. De Krey, 'Reformation and "Arbitrary Government": London Dissenters and James II's Polity of Toleration, 1687-88', in Fear, Exclusion and Revolution: Roger Morrice and Britain in the 1680s, ed., Jason McElligott (Aldershot: Ashgate, 2006), 15-6, 23-4.

108 Spurr, 'Schism and the Restoration Church', Journal of Ecclesiastical History 41, no. 3 (1990): 415.
} 
their call for religious unity under the Anglican hegemony guaranteed by the godly ruler. The prominent apocalyptic commentator Henry More, for example, claimed the purpose of his exposition of the apocalypse was not only to assure the biblical truth but to show the 'apparent Usefulness thereof, for the general Peace of Christendom, for Loyalty to Sovereigns, whether they be of the Reformed or Unreformed Religion, for securing to Monarchs their Crowns, for the preventing barbarous Bloodshed in the Christian World, and for the extinguishing Sects and Schisms, especially here in our own Nation'. ${ }^{109}$ This complicated picture of the Anglican advocacy of unity and detestation of religious separation from the established Church of England was what the majority of churchmen were concerned with throughout the Restoration, even after the Glorious Revolution.

These responses to both dissenting schism and Catholic opposition, thus, formed latitudinarians' concern of religious stability made by religious unity. Stillingfleet, for example, thought that the division within the church would destroy religious unity and peace in a society too. For him, the justification of the civil magistrate's rights rested upon how firmly the secular magistrate could keep the kingdom peaceful and united. Peace and unity were of great importance in maintaining both the church and state. He warned about sectaries destructive to England:

1. That that the Principles and practices of the Jesuitical party in the Roman

Church, are as destructive to Government, as of the most Fanatick Sectaries, which ever hath been among us. ${ }^{110}$

He thought that religious sects were liable to be harmful to social tranquility. Stillingfleet's view of the role of civil magistrate in religion was understood in the context of his insistence upon episcopacy, an insistence which made vehement use of sensitivities around Catholicism or, on occasion, schism. Demonstration and argumentation were mainly targeted at the Catholic polemic for universal and supreme authority of the pope over the church. Against schism and Catholicism, he argued that unity was required in the church. However, this was not the unity of judgment among all members of the church. His claim for religious unity was in reference to practical matters like liturgy and the way of worship.

\footnotetext{
109 Henry More, Paralipomena Prophetica: Containing Several Supplemenss and Defences of Dr H. More (London, 1685), iii-iv.

${ }^{110}$ Stillingfleet, A Discourse Concerning the Idolatry Practised in the Church of Rome (London, 1671), 304.
} 
Stillingfleet continued to explain the difference between the meanings of unity and peace and those of the Roman Church. When Catholics denigrated Anglican separation from papal hierarchy and emphasised Catholic-centred unity, he argued, Catholic unity was far from what true religion was meant to be. In criticizing Caesar Baronius, an Italian cardinal and historians of the Roman Church, who supported religious unity under papal authority, for example, Stillingfleet argued that the history of the Catholic Church proved that Baronius' argument was wrong. Stillingfleet articulated that history of Councils where popes asserted infallibility on all religious affairs witnessed the fact that they failed to achieve religious unity under one universal church, and that there were internal conflicts and divisions within the Catholic Church. Stillingfleet thought that when Baronius asserted that God's providence would not allow the devil's kingdom to stand, this apocalyptic prophecy paradoxically represented Catholicism itself regardless of the Catholic priest's intention. $^{111}$

Discussing the role of magistrate and the relationship between the civil and ecclesiastical authorities, Stillingfleet asserted the usefulness of episcopacy in England. The main ground for the establishment of episcopacy in the country rested on the expediency of the state. The process of the triumph of the Church of England was, he thought, well seen in the history of the Reformation in England. Since the positive law had to be legislated only by the legitimate magistrate, he understood, any decision about 'indifferent things' from religious core principles was to be judged by social utility. In other words, civil authority was needed for legitimating all indifferent things in religion.

The latitudinarians made constant attempts to establish religious unity by accepting a comprehension. Comprehension aimed to embrace the moderate Nonconformist clergy - mainly Presbyterians - within the national church by revising the ceremonies and liturgy of the Church of England. The comprehension bill 'limited the terms of subscription to the Prayer Book and to the Thirty-nine Articles' so that Presbyterian clergy would easily admitted into the Church of England. ${ }^{112}$ The claim for comprehension was the latitudinarians' main scheme to gain religious unity after the Interregnum. Their proposal of comprehension

\footnotetext{
111 Ibid., 342-44, 49.

112 Robert D. Cornwall, Visible and Apostolic: The Constitution of the Church in High Church Anglican and Non-Juror Thought (London: Associated University Presses, 1993), 33.
} 
repeatedly pursued until 1689 when the comprehension bill failed to be passed by Parliament the limited toleration bill were enforced. Comprehension could be regarded as a religious compromise not only to support royal supremacy over religion in a moderate way but also to the superiority of the Church of England over dissenters.

While political and religious issues of appeasement policy towards Nonconformists loomed large, a religious scheme of comprehension came to the surface. This caught many people's attention. Samuel Pepys, for example, wrote in his diary that there had been 'great presumption' that 'A Toleration will be granted, even though the Presbyterians would hardly trust in the king or Parliament. ${ }^{113}$ After the fall of Clarendon in 1667, the royal court got set to introduce bills of comprehension and indulgence. Even though Charles II had to withdraw the Declaration in 1663, in short course he issued the Indulgence in 1672. ${ }^{114}$ These actions embarrassed many supporters of the Church of England. Within the decade there was a notional controversy over these issues among the leading religious elites and polemicists like the Independent John Owen, the Quaker William Penn, the Latitudinarian Simon Patrick, and the High-churchmen, such as Samuel Parker and L'Estrange and so on. ${ }^{115}$

The latitudinarian defence of comprehension had relied upon the thought that adiaphora, 'indifferent', was a matter for the magistrate to decide, not for priests. Their religious policy of comprehension aimed to allow moderate dissenters to be included within the boundaries of the Church of England. From the late 1660s some latitudinarian clergy including John Wilkins set out to take part in negotiations with Nonconformists in order to persuade them to conform to the modified doctrines and practices of the Church of England. The project of comprehension faced attacks from conformist colleagues. The latitudinarians found themselves being accused of schism for allegedly supporting liberty of conscience; the policy of comprehension being of nothing in the eyes of critics but a design to assemble all sects into a religion. ${ }^{116}$

Latitudinarians' promotion of comprehension was never successful during the

113 Samuel Pepys, The Diary of Samuel Pepys, Vol. 9, 1668-1669, ed., Robert Latham and William Matthews (London: Bell, 1976), 31.

${ }^{114}$ Goldie has provided more details of both claims for the rights of conscience and for opposition to toleration. See Goldie, 'Toleration and the Godly Prince in Restoration England'.

115 N. H. Keeble, The Restoration: England in the 1660s (Oxford: Blackwell Publishers, 2002), 124.

116 Nicholas Tyacke, 'From Laudians to Latitudinarians: A Shifting Balance of Theological Force', in The Later Stuart Church, 1660-1714, ed., Grant Tapsell (Manchester: Manchester University Press, 2012), 50-1. 
Restoration. A series of comprehension bills were introduced to Parliament, beginning in 1667, but all were rejected. As Spurr demonstrates in detail, there was the common sense among the majority of Anglican clergy that a comprehension would not contribute to unity but introduce schism into 'the bowels of the church'. They believed that a nation 'divided against itself could not stand and that schism would cause the growth of atheism and irreligion. ${ }^{117}$ Dissenters too refused the proposal of comprehension because they simply depicted the Church of England as being unreliable for its persecuting them. ${ }^{118}$ After the new regime attempted to put forward its policy of toleration, it turned out that comprehension was the failure and latitudinarian clergy should accept the new policy. Cragg notes that the fact that they dealt with religious matters in a pragmatic way stood out after they were elevated to bishoprics by William and Mary. ${ }^{119}$ They were ready to be embrace comprehension and then toleration as a means of securing unity when the king, William III, introduced the religious conciliatory policy.

It is apparent that their advocacy of William's religious policy partly came from king's support of these latitudinarians. When the new king came to his throne, he favored latitudinarian clergy and nominated some of them as bishops. It seems obvious that the king's preferential treatment of these moderate Anglicans arose from his religious orientation towards toleration. In other words, the reason why William was in favor of the moderate churchmen was, as F. G. James argues, because he was supportive of tolerance towards nonconforming groups and he thought that the latitudinarians were a good political partner for this religious policy. ${ }^{120}$ In the aftermath of the revolutionary event the king deposed non-juring bishops who refused to swear loyalty to the new regime, and ordered Tillotson to succeed William Sancroft (1617-1693) as archbishop of Canterbury in 1691 with Burnet elevated to Salisbury and Stillingfleet to Worcester in 1689, Fowler to Gloucester in 1691, Patrick to Chichester and subsequently to Ely in 1691, and Tenison to the see of Canterbury from $1695 .{ }^{121}$ This is not to say that the latitudinarian bishops

\footnotetext{
117 Spurr, 'The Church of England, Comprehension and the Toleration Act of 1689', English Historical Review 104, no. 413 (1989): 944.

118 Loc. cit.

119 Gerald R. Cragg, From Puritanism to the Age of Reason: A Study of Changes in Religious Thought within the Church of England, 1660 to 1700 (Cambridge: Cambridge University Press, 1950), 73-4.

${ }^{120}$ F. G. James, 'The Bishops in Politics, 1688-1714', in Conflict in Stuart England, eds., William Appleton Aiken and Basil Duke Henning (Hamden, Conn.: Archon Books, 1970), 232-33.

121 W. M. Spellman, The Latitudinarians and the Church of England, 1660-1700 (Athens, Georgia: University of
} 
diametrically turned their ecclesiological orientation to comprehension into a recommendation of toleration, yet the co-operation between the godly monarch and newly ordained bishops would have effected an union of the English Protestants which they had proposed in a loose sense.

Whether it was to Hobbist or Socinian perspectives that the latitudinarians' religious rivals had ascribed the problem of latitudinarians perception of the nature of civil and ecclesiastical authorities, it was only on religious grounds that the civil magistrate was able to exercise his divine authority over his subjects. To tell the truth, these Anglican clergy hardly displayed the detailed explanation of the monarch's authority and rights in legal terms as prominent political polemicists like Hobbes and Locke did. With prophetic illustrations derived from the Scriptures the civil ruler was embellished and described as the godly guardian of his subjects, and king's divine right was guaranteed by religious terms, largely apocalyptic and prophetic ones. Apocalyptic ideas deeply reflected their political attitudes. For the Anglican divines the grand narrative of biblical prophecies including the Last Days was not only an image which had attracted many contemporaries but also met the expectation people had of politics. The moderate version of apocalyptic interpretation was applied by the latitudinarians to English politics in the later seventeenth-century. Adhering to More's interpretive framework for biblical prophecies, they thought that their prophetic interpretations of political circumstances would reinforce the legitimacy of the authority of the king and church. Without taking their apocalyptic expectation of the godly magistrate into consideration, it is difficult to draw a full picture of how these moderate clergymen viewed civil authority. The use of conventional language maintained their insistence on the role of the secular magistrate as promoting the true 'catholic' church, the Church of England, although the extent to which they felt loyal to the Stuart monarchs varied over time. With historical experiences of political tumult and restoration and political conflicts between the Church of England and the royal court, providential interpretation of English history from the Reformation to the Revolution of 1688-1689 and apocalyptic vision of the English monarch contributed to shaping the terms and rhetoric used by the latitudinarians.

Despite the fact that some elements of Erastianism were manifest in these moderates' ecclesiology, it does not mean that the contending polemicists' 
identification of the latitudinarians with 'Hobbesian' or 'Socinian' is justified. Examining the latitudinarians' arguments of the relationship between religion and state is far from affirming the existence of Hobbism in their understanding of religion. Rather, this chapter has disclosed their use of various levels of language. They used apocalyptic language which reinforced an image of the monarch. The image was a godly ruler who was given power by God to maintain the peace and unity of society by promoting true religion.

This chapter attempts to shed light on latitudinarian views of the godly ruler that have been little discussed by historians. Their use of apocalyptic language in the discourse of the royal supremacy demonstrates the different version of apocalyptic approach to current political issues. Considering their understanding of the civil magistrate helps discover the distinct features of Anglican apocalyptic ideas. The moderate Anglican apocalyptic description of the monarch refuses the view that the late seventeenth-century apocalypticism was predominantly asserted by Nonconformists, especially extreme groups, for their radical purposes.

It is not surprising that the Church of England often appealed to apocalyptic imagery in support of the established order. They felt the need to place the restored English church and monarch into the apocalyptic context. It was a commonplace that they saw the restoration of Charles II and the Church of England as the fulfilment of biblical prophecies. Thus, Anglican apocalyptic interpretation was made to justify Restoration political and religious orders.

Compared to dissenting proponents of millenarianism, there is little literary evidence in the latitudinarian writings of their commitment to millenarianism. However, they were committed to the providential idea of the godly ruler protecting religion in England. Like other Anglican divines, they hoped that the king would impose some regulations upon dissenters and Catholics to settle the re-established Church of England. Their expectations of monarchical protection for the established church, in spite of some fluctuations in tone, were consistent till the late seventeenth century.

This suggests that the latitudinarians' view of relations between the state and 
church rested upon a variety of political and religious premises. They promoted an irenic agenda, preferring the comprehensive policy towards Nonconformists. On the other hand, they also adopted the Reformation apocalyptic tradition to describe royal authority over the church. In this sense, the assumption that the latitudinarians were merely advocating modern theological and political ideas should be criticized. The examination of the context of the debate over the royal supremacy allows them to be placed in a wide variety of historical settings. 


\section{Chapter 5 \\ Providence, Progress, and Moral Reform}

The previous chapters have revealed how the latitudinarian clergy connected their religious and political arguments to apocalyptic convictions and language. The latitudinarians shared this apocalyptic vocabulary with many other English Protestants of the mid and late seventeenth century. Apocalyptic ideas were implicit, sometimes explicit, in a variety of debates in which these clergy were engaged from the Restoration onwards. Latitudinarians quite naturally used apocalyptic terms in their thinking about Roman Catholicism, the Church of England, and the monarchy. So the latitudinarians' famous commitment to reason and rationality did not impede or contradict their reliance on a more traditional way of thinking when it came to issues such as the Apocalypse and divine providence. Indeed, many of them saw the way in which they constructed theological discourses as a combination of traditional approaches with more recognizably modern concerns. This dissertation investigates the balance of the traditional and the innovative in latitudinarian thinking and assesses the degree of continuity and change between their apocalyptic thinking and that of their predecessors and contemporaries.

One area of possible continuity lies in latitudinarian apocalyptic views of the past and especially of religious history. As M. C. Jacob and W. A. Lockwood explain, English Protestants found the history of human beings explicable through a series of apocalyptic events, such as 'the captivity of the Jews, the birth and death of Christ, the corruption of Christianity by the Roman Church, its renewal at the Reformation, and ending with the second coming of Christ and millennial paradise'. ${ }^{1}$ Latitudinarian thinking was broadly similar: they believed that the apocalypse was the key to human history and thus maintained a sense that divine providence continued to intervene in England's life and politics. They applied apocalyptic narratives to significant events in the recent past including the Reformation, the English Civil War, and the Restoration of the monarchy. Following the English apocalyptic tradition developed by Joseph Mede and Henry More, the latitudinarians thought that human history was driven by the providential plan which would

\footnotetext{
${ }^{1}$ M. C. Jacob and W. A. Lockwood, 'Political Millenarianism and Burnet's Sacred Theory', Science Studies 2, no. 3 (1972): 266.
} 
accomplish the prophecies until the end of the world. While Mede and More identified historical stages with apocalyptic images in the prophecies of Daniel and St John, the latitudinarians were silent about detailed interpretation of the apocalypse. So for all their apocalyptic language and providentialism, the latitudinarians parted company with the wider English tradition of apocalyptic thought when it came to the nature of the future apocalypse. They do not seem to have taken much interest in the millennial reign of Christ on Earth. Unlike some radical puritans such as proponents of millenarianism who were convinced of radical transformation of political situations, the new heaven was seen by latitudinarians as a stage of history when the existing order including the established Church of England and the monarchy were to be maintained.

For latitudinarian Anglicans it was important to see how God's providential plan would be realized in the flow of human history, not to explain what would happen at the end of the world in detail. A leading characteristic of latitudinarian views of providence was that the world had not yet come to the final stage of human history. The world was still being threatened by the forces of evil and human beings did not always follow God's plan. Providence was seen as part of the process of history: God's purpose for mankind connected the recent past, the current situation and the immediate and longer-term future. In the latitudinarians' providential worldview the idea of providence was related to a concept of progress. It is important to note that latitudinarians' view of religious history assumed that religion was necessary for further development. I will show that these Anglican clergymen saw religious progress as a continuous advance prompted and supported by divine providence. For ease of explanation, religious progress can be described very briefly as related to the improvement of human nature and morality. As this chapter will suggest, sinful imperfect human beings needed further opportunities to improve their moral behavior and in some sense become worthy of God's mercy and of salvation. This notion was encapsulated in the contemporary term 'moral reform'. Providence prompted moral revival at the individual and national levels. Latitudinarians, and other clergy, were preoccupied with moral deficiency of individuals and collective immorality. They believed that godliness would influence divine judgment: immorality could provoke God's wrath and good manners might help advance the apocalyptic climax. Therefore, the warning of divine punishment for impiety was a 
central theme of their pastoral ministry. After the Church of England was reestablished in England, many clergy emphasised the urgent need for the parallel restoration of national godliness.

There are therefore three interrelated themes of this chapter - as its title indicates - providential thought, the possibility of human progress, and the ethical and theological implications of the drive for 'moral reform'. Moral reform was a major preoccupation of the later seventeenth century. This chapter outlines the providential framework of Anglican churchmen concerned with promoting moral renewal. Moral reform has attracted attention from a number of scholars in recent years. While many historians have focused upon the religious movement of the reformation of manners from the Revolution of 1688-1689, a few works have provided a detailed explanation of English Protestants' commitment to godly life throughout the Restoration period. Historians have explored the religious and cultural dimensions of the reformation of manners in the William III's reign. Their major research focuses on the nature of some specific type of religious movements for the reformation of manners that led to the establishment of reformation societies - the Society for Promoting Christian Knowledge (SPCK) and the Society for the Propagation of the Gospel in Foreign Parts (SPG) - during the late seventeenthcentury and early eighteenth century. ${ }^{2}$ There has been less analysis of the ways in which the members of the Church of England - whether clerical or lay - regarded themselves as being deeply involved in the godly reformation in many ways. John Spurr, for example, shows that Anglican churchmen were concerned about the spiritual dangers posed by sectarianism, vice and impiety and busily promoted godliness from the Civil Wars of the 1640s onwards. ${ }^{3}$ William J. Bulman has also traced the ways the Anglican clergy responded to the challenge of encouraging simple moral virtue at the height of the Puritan Revolution in the 1640s and 1650s. ${ }^{4}$

\footnotetext{
2 Tony Claydon, William III and the Godly Revolution (Cambridge: Cambridge University Press, 1996); Eamon Duffy, 'Primitive Christianity Revived: Religious Renewal in Augustan England', Studies in Church History 14 (1977): 287-300; Brent S. Sirota, The Christian Monitors: The Church of England and the Age of Benevolence, 1680-1730 (New Haven: Yale University Press, 2014); Craig Rose, 'Providence, Protestant Union and Godly Reformation in the 1690s', Transactions of the Royal Historical Society 3 (1993): 151-69; David Hayton, 'Moral Reform and Country Politics in the Late Seventeenth-Century House of Commons', Past and Present 128 (1990): 48-91.

3 John. Spurr, The Restoration Church of England, 1646-1689 (New Haven: Yale University Press, 1991), chap. 5.

${ }^{4}$ William J. Bulman, Anglican Enlightenment: Orientalism, Religion and Politics in England and Its Empire, 1648-1715 (Cambridge: Cambridge University Press, 2015).
} 
Latitudinarians have been particularly identified with the campaign for moral reform. The emphasis on the moral life has been thought to be associated with their insistence on a rational approach to religion and a confidence in the power of human reason. As Isabel Rivers shows, the latitudinarians believed in the 'optimism about human nature' and enhancement of morality through the human rational faculty. But Rivers' claim seems to underestimate the role of the traditional framework in the development of perception of the human capacity for reason. Although Rivers notes that the latitudinarians 'regarded themselves as the true heirs of the Christian tradition running from the early church through medieval scholasticism and Renaissance humanism to seventeenth-century Arminianism in its various forms', she stresses that they did not hide the role of rationalism in their understanding of human nature and its potential. ${ }^{5}$ Latitudinarians also owed much to the theological and moral teaching of the Anglican 'holy living' school. With the pursuit of holiness defined in terms of religious and devotional duty, these latitudinarian divines' sermons took arguments for morality from famous works of Anglican soteriology, Henry Hammond's Practical Catechism (1646), and The Practice of Christian Graces, or the Whole Duty of Man (1658), prefaced by Hammond and almost certainly written by Richard Allestree. ${ }^{6}$ As will be shown below, such books were mainly concerned with the practices and rule of holy living and rejected the Calvinist belief in predestination. There is no doubt that they influenced the latitudinarians' main tenet that the end of religion was to promote true moral performance.

Scholars of the institutional and theological aspects of the campaign for moral reform have therefore uncovered a great deal about the sources of the latitudinarians' moral preaching. Less has been said, however, about how providential ideas played a significant role in building up the whole framework of godly reformation. For these moderate conformists, the reformation of moral virtues was provoked as much by the providential explanation of the fate of England as by the rational discussion of Christianity.

This chapter explores its three main themes of providence, progress and moral reform across five sections. The first section describes the widespread fear of

\footnotetext{
${ }^{5}$ Isabel Rivers, Reason, Grace, and Sentiment: A Study of the Language of Religion and Ethics in England, 1660-1780, Vol. 1, Whichcote to Wesley (Cambridge: Cambridge University Press, 1991), 87-8.

${ }^{6}$ N. H. Keeble, The Restoration: England in the 1660s (Oxford: Blackwell Publishers, 2002), 127; Spurr,

“"Latitudinarianism” and the Restoration Church', The Historical Journal 31, no. 1 (1988): 81.
} 
divine judgements as seen in the providential sermons preached on fast days. The second section describes how the core Christian principle of repentance was used by latitudinarian divines to connect individual sin and communal depravity and to motivate moral reformation. This providential discussion of divine control and human free will informs the third section of the chapter which considers the traditions of Anglican and Calvinist soteriology and their underlying ideas about human freedom and perfectibility. Section four puts these ideas into a broader context and offers an account of the thinking of Jeremy Taylor and John Tillotson. The fifth and final part considers how Christian individuals can be trained or educated to be moral, and the implications of such progressive and optimistic thinking for conventional Christian notions of sin or the apocalypse. The writings of Ernest Tuveson are a helpful tool in evaluating how far the notion of human progress had replaced traditional apocalyptic thinking among the latitudinarians.

Two main arguments run throughout this chapter. The first engages the latitudinarians' providential rationale for moral reform. As providential ideas justified the whole course of the Reformation from the sixteenth century, the latitudinarians knew the providential plan encouraged them to seek the Christian virtues promoted by Protestants since the Reformation. The integration of history and providence gave rise to two passions: the hope for a glorious future to which God would lead his people, and the fear of God's judgement upon human sins. These two emotions of hope and fear associated with apocalyptic, providential, judgements certainly prompted moral reform.

The second argument concerns the latitudinarians' optimistic attitude towards human nature. The latitudinarians' interpretation of human nature was based on the gradual progress of the historical process. They believed that God's apocalyptic plan for human beings served as a stimulus to the improvement or perfection of human nature. This distinctive notion of human perfectibility was related to their soteriology. For latitudinarians, God's providence did not exclude human free will. Rather, providence encouraged people to use their free will to bring about the perfection of human beings through their cooperation with God. Latitudinarian belief in moral progress should be seen in the context of the amalgamation of traditional religious ideas and the relatively modern concept of the possibility of progress in human morality. In short, the chapter concludes that the latitudinarians' notion of godly 
reformation was based on a mixture of apocalyptic expectations of human perfection and human active participation in the enhancement of religious virtues.

\subsection{The Fear of Divine Judgement}

One of the primary reasons for latitudinarians' preoccupation with morality arose from the widespread contemporary belief that late seventeenth-century English people were living in an immoral age. The latitudinarians agreed with Anglican contemporaries on a sense of crisis in terms of the Protestant church 'in danger'. As previous chapters argued, the popish threat to the security of the Church of England and the monarchy, along with animosity towards fanaticism and atheism, inculcated a profound sense of instability in English minds. Additionally, a series of recent experiences, such as the execution of Charles I and the English Civil War, were seen as severe punishments inflicted on a sinful England by an angry God. These devastating signs strengthened the latitudinarians' conviction that they were in dark days and a revival of 'true piety' was necessary in their nation. ${ }^{7}$ Immorality and insecurity formed a mutually reinforcing pair: where one existed, the other was the cause. That the Church of England and the tradition of the Reformation had been threatened politically abroad and at home caused them believe that the nation was being threatened by immorality and irreligion.

The latitudinarians placed great hope in the potential of God's apocalyptic scheme. Many regarded the restoration of monarchy and the Church of England in 1660 as a glorious moment designed by divine providence. Political changes provided conformists with circumstances in which the composition of apocalyptic literature was encouraged. The Anglican churchmen made use of apocalyptic images to support the restored government and the re-established Church of England. Two anonymous works, for example, used prophecy as a political support of the king and the episcopal church by identifying 'the rise of dead witnesses' with the restorations of Anglican bishops and Charles II. ${ }^{8}$ The latitudinarian divines also depicted the Restoration as a sign of progress towards an apocalyptic victory. Henry More, for

\footnotetext{
7 Spurr, The Restoration Church of England, 1646-1689, 238-40.

8 Warren Johnston, 'The Anglican Apocalypse in Restoration England', The Journal of Ecclesiastical History 55, no. 3 (2004): 475-80, 90; 'Revelation and the Revolution of 1688-1689', The Historical Journal 48, no. 2 (2005): 374-75.
} 
example, compared the Reformation with the rise of witnesses in the Book of Revelation, claiming that 'the blessed Reformation begun by Luther, was the Rising of the Witnesses, which most naturally must beget a peaceful mind in men, and due value for our Church'?

On the other hand, it was acknowledged that if a population offended God then divine providence would be silent about their sufferings under antichristian persecution or other deserved punishments. ${ }^{10}$ Many clergymen felt that English church enjoyed an uneasy peace. For the seventeenth-century Anglicans, the growth of profaneness and depravity inevitably caused divine severe judgment over them. The warnings against immorality were expressed in apocalyptic terms. The Church of England encouraged lay people to confess their sins and turn back from the slavery of Satan.

Restoration Anglicans also learned the bitter lessons of divine punishment from their apocalyptic understanding of history. They saw natural catastrophes and unfortunate events as temporal divine judgements. They also believed that divine chastisements were provoked by the nation's spiritual and moral degeneracy. Burnet asserted that irreligion, luxury, injustice, and oppression led to the corruption of the human mind. Irreligion, in other words, idolatry and profaneness, were major attributes of the sinner, and these had left them far from returning to repentance. In his sermon, the deviation of the Ten Tribes of Israel from their previously desired worship was an allusion to the religious situation in later seventeenth-century England. Burnet regarded the depiction of them who 'minded nothing but the external Pagantry, the Musick, and other outward Performances, and were weary often of these, so that their solemn Days were Abominations to God' as similar to that of the English who 'in compliance with Custom go to Church, do it merely for Form', and show 'their vain Apparel, and dress themselves with such gawdy Pomp'. ${ }^{11}$ Given that many Anglicans felt that there was still a popish conspiracy to subvert the English church and state, it would be right to understand that Burnet

\footnotetext{
${ }^{9}$ Henry More, Paralipomena Prophetica: Containing Several Supplemenss and Defences of Dr H. More (London, 1685), 203.

${ }_{10}$ Stephen Taylor, 'Afterword: State Formation, Political Stability and the Revolution of 1688', in The Final Crisis of the Stuart Monarchy: The Revolutions of 1688-91 in Their British, Atlantic and European Contexts, eds., Tim Harris and Stephen Taylor (Woodbridge: The Boydell Press, 2013), 286.

${ }^{11}$ Gilbert Burnet, A Sermon Preached before the Right-Honourable the Lord-Mayor and Aldermen of the City of London, at Bow-Church, September 2, 1680. Being the Anniversary Fast for the Burning of London (London, 1680), 10.
} 
mainly aimed at Catholicism and atheism when he accused the nation of irreligion. Burnet believed that atheism and idolatrous Catholicism prevented the people from understanding the truth of the gospel. Stillingfleet also seriously worried about the danger of anything which could drive Christians into irreligion. Out of fear he warned that God did forbore the people of Judah, 'waiting for their amendment', but when 'they added impudence to their obstinacy', ... then the peremptory decree of judgment upon them came forth and 'there was no hopes to escape'. ${ }^{12}$ The problem, for Stillingfleet, was that atheism or profaneness grew impudent and bare faced so that men finally not only neglected religion but reproached and condemned it. Stillingfleet did not doubt the close connection of Catholicism with atheism and profaneness. What he feared was that atheism might open the back door for Popery to return to England. ${ }^{13}$ The prophetic theme of divine judgement promoted a sense of urgency and the apocalyptic understanding of the last judgement implied a constant alert for the future. The threat came from close to home too: the Protestant Church of England was still in danger from lay irreligion, Nonconformist hypocrisy, sectarianism and radical enthusiasm.

Many of these dangers went back to the dark years of the Civil War and Interregnum. Several years before the Restoration, in his epistle to Lord Vaughan, Jeremy Taylor admonished members of the church to 'make use of the proper instruments of virtue' in the midst of difficult circumstances when the Church of England was thought to be 'forsaken' by God. ${ }^{14}$ While it was apparent that the Church of England was settled after 1660 and its institutions were restored, contemporaries did not think that English religion and piety stood on firm ground. At the height of the Great Plague in 1665, Simon Patrick wrote that 'the face of things is now so calamitous, and there is so much sadness discovers it self in the looks of all those who are serious and affected with our present miseries'. In order to overcome sufferings, he argued that 'it seems as great a deed of charity to send some comfort to them, as to call the careless world to Repentance'. ${ }^{15}$ The latitudinarians

\footnotetext{
12 Edward Stillingfleet, A Sermon Preached on the Fast-Day November 13, 1678 at St. Margarets Westminster before the Honourable House of Commons (London, 1679), 38.

${ }^{13}$ Ibid., 47.

14 Jeremy Taylor, Holy Living in Which Are Described the Means and Instruments of Obtaining Every Virtue, and the Remedies against Every Vice, and Considerations Serving to the Resisting All Temptations, 5th ed. (London, 1656), sig. A8v.

${ }^{15}$ Simon Patrick, Consolatory Discourse, Perswading to a Chearfull Trust in God in These Times of Trouble and Danger (London, 1665), 1.
} 
saw a series of events in their lifetimes as signs of God's judgement on them. The wars, disasters, and religious schism including the fear of Catholicism were thought to represent the uneasy peace between God and the English during the Restoration. ${ }^{16}$

In a sermon preached in the summer of 1667 the 'latitude-man' John Tillotson quoted passages from Isaiah 9: 12 and 13 to arouse the fear of God's judgment on the people who were accused of turning away from Christ. The reason why God sent judgments upon the people was to 'reclaim them from their sins'. 'God's aim at in his Judgments', said Tillotson, was to take us from 'our sins, and to bring us to Himself'. For Tillotson, the scriptures fully illustrated the continuation of God's judgment. It was fearful to him, therefore, that 'God's anger is not turned away, but his hand is stretched out still, because the people turneth not unto him that smiteth them'. ${ }^{17}$ As shown above, the latitudinarians asserted the necessity of repentance and warned the English against moral decline.

The rhetoric of providence was still effective in conveying an alarming message of divine retribution for moral degeneracy. Englishmen tended to think that the providence of God had driven them to contrition for their vices. They were convinced that God had sent divine messages to His people through weighty events like wars, pestilence, and fire. Tillotson could easily identify these events with terrible messages of His wrath. God gave the English some considerable victories in 'Foreign War', yet they provoked God so they were punished by the following sufferings like a plague and the Great Fire. ${ }^{18}$ In his sermon on the fast for the Popish Plot, Edward Stillingfleet also preached on providence. He mentioned the validity of the term of providence by saying that 'there is a superior cause to the Counsels of Men which governs the affairs of mankind which he [Machiavel] calls Fate, and we much better, the Providence of God'. ${ }^{19}$ Stillingfleet went on to say the relationship between human sins and punishments on human societies. He stressed that the scriptures witnessed the kingdom's ruin influenced by the continuation of sins. Stillingfleet borrowed an Old Testament passage saying that 'If ye shall still do wickedly, ye shall be consumed, both ye and your King'. His warning of God's

\footnotetext{
16 Spurr, The Restoration Church of England, 1646-1689, 245.

17 John Tillotson, 'A Sermon Preached before the King June 30th 1667', in Sermons Preach'd Upon Several Occasions, vol. 2 (London, 1678), 4.

${ }^{18}$ Ibid., 20.

${ }_{19}$ Stillingfleet, A Sermon Preached on the Fast-Day November 13, 1678 at St. Margarets Westminster before the Honourable House of Commons, 22.
} 
wrath led the people to a conclusion that 'the best means for the welfare and preservation of it, viz. maintaining and practicing the true Religion' was to 'fear the Lord and serve him in truth with all your heart'. ${ }^{20}$

After the Revolution of 1688-89 the apocalyptic interpretation of significant events flourished. As Craig Rose shows, for example, defeats in wars against neighbouring countries, and natural catastrophes like the earthquake of 1692 in Port Royal, Jamaica and the London tremor of the same year were seen as warnings of unfinished divine judgement. ${ }^{21}$ This framework still offered a perspective on history in the early eighteenth century. Clark adds Thomas Harrison's catalogue of divine chastisements, including the plagues from the medieval period, the Fire of London in 1666, and several violent storms in 1661 and $1703 .{ }^{22}$ Rose and Clark present an abundance of the seventeenth-century and early eighteenth-century literature by both Nonconformists and Anglicans to demonstrate that the early modern English people shared, to some extent, a providential mode of thought by which they saw every single thing as destined to come by God's providence. Belief in the imminent end of the world was a commonplace element of apocalyptic thought.

Although the Anglican adherence to providentialism was common, the degree to which Protestants employed the providential frame of mind differed. During the second half of the seventeenth century providential belief played a key role in the understanding of the world. A difference between the 'Williamites' and 'Jacobites' in their use of providential rhetoric surrounding the events of the Revolution rested upon whether the Revolution was 'a sudden and seasonable deliverance' or a provocation for 'God Almighty's anger'. ${ }^{23}$ While opponents of the Revolution of 1688 like Nathaniel Johnston claimed that the revolution would give England nothing but all the misfortunes, the supporters of William's reign naturally viewed the post-revolutionary period in an optimistic way: God would deliver the people to salvation. ${ }^{24}$ The latitudinarian clergy elevated to bishoprics after the William's succession to the throne did not hide their hope for the godly future England would enjoy along with their godly prince. For them providence was basically directed at

\footnotetext{
20 Ibid., 11.

21 Rose, 'Providence, Protestant Union and Godly Reformation in the 1690s', 151-69. There were the people who understood the Jamaica earthquake in connection with the London tremor throughout a providential lens.

22 J. C. D. Clark, 'Providence, Predestination and Progress: Or, Did the Enlightenment Fail?', Albion: A Quarterly Journal Concerned with British Studies 35, no. 4 (2003): 561.

${ }_{23}$ Rose, 'Providence, Protestant Union and Godly Reformation in the 1690s', 154-55.

${ }^{24}$ Ibid., 153-54.
} 
propelling the people towards divine happiness, in other words, the salvation of their souls.

William III's accession to the throne and the expulsion of the Catholic James II tempted the latitudinarians to lean more on the revelation of providence than before. Gilbert Burnet's apocalyptic ideas well represented providential discourse in the late seventeenth century. The latitudinarian bishops including Burnet conspicuously set forth the providential rhetoric of national reformation. ${ }^{25}$ Burnet emphasised that the Revolution had vindicated the key images of providence, like the true church, godly magistracy, and moral reform. For Burnet some events before William's invasion showed apocalyptic sign of the Revolution. Burnet's many sermons preached during the late 1680s provided numerous evidences of God's support for the Protestant prince and religious reformation. ${ }^{26}$

Tillotson admitted that providence governed the world and concerned 'it self in the Affairs of Men, and disposeth of all Events that happen to us'. ${ }^{27}$ Instead of enumerating proofs of the providence of God, Tillotson attributed all human affairs to the 'wise providence' of God because of a great deal of nicety and difficulty in explaining it. ${ }^{28}$ Tillotson's vindication of providence was a rebuttal of of so-called 'Epicurean' theology that denied any divine intervention in human affairs. 'Tis true indeed the Epicureans did deny', said Tillotson, 'that God either made the World, or governs it; and therefore wise Men always doubted whether they did indeed believe the Being of God, or not'. ${ }^{29}$ Contrary to this deist argument, Tillotson's providentialism asserted divine intervention in all natural phenomena and human events.

But now Divine Revelation hath put this matter out of doubt, by assuring us of God's particular care of all Persons and Events. Our Saviour tells us, that God's Providence extends to the least and most inconsiderable Creatures, ... Much more doth the Providence of God extend to Men, which are Creatures far more considerable, and to the very least thing that belongs to us, to the

\footnotetext{
${ }^{25}$ Sirota, The Christian Monitors: The Church of England and the Age of Benevolence, 1680-1730, 93.

26 Ibid., 50-2.

27 Tillotson, 'The Wisdom of God, in His Providence Preached at Kensington', in Several Discourses Upon the Attributes of God, ed., Ralph Barker (London, 1699), 246.

${ }^{28}$ Ibid., 248.

29 Ibid., 250.
} 
very hairs of our head, which are all numbered, the lowest instance that can be thought on. ${ }^{30}$

But Tillotson, in common with other latitudinarians, did not ignore the devastating consequences of human depravity. The second half of his sermon was devoted to an explanation of the divine purpose of bad events. He saw that the providence was primarily concerned for good men and took care of them. He continued that God's blessing was given to good men with prosperity and success in their affairs. It could therefore be inferred that good people could fall into bad situations for good ends. 'The Providence of God', he said, 'usually ordereth it so, that they are armed with great Patience to bear them, and find great comfort and support under them, and make better use and improvement of them than others' ${ }^{31}$ In his mind, God's wisdom and good will sought only to offer eternal happiness to people. Thus he could exhort his audience to use their own 'best diligence', and study to 'please him', and 'cheerfully leave our selves in his Hands, with the greatest confidence and security'. ${ }^{32}$ God's government of the human world through the dispensations of providence was a clear message that human beings should avoid provoking the Almighty's wrath. Repentance for sin and a commitment to improvement was obviously the wisest course of action.

\subsection{The Necessity of Repentance}

In Protestant minds, the first step to mitigate divine punishment for human sins was penitence for past vices. Repentance was conceived as the way of leading England to salvation. With a warning of future judgments, reflection and penitence were attached to sermons and works for special occasions like thanksgivings throughout the Restoration period. ${ }^{33}$ The latitudinarian clergy also lifted up their voice against national or personal vices. They thought that the country should pursue the restoration of true religion by turning its back on spiritual and physical corruption. The reformation of religion was to begin with the repentance which was a prerequisite to moral reform.

\footnotetext{
30 Ibid., 251.

31 Ibid., 255.

${ }^{32}$ Ibid., 258-60.

33 Andrew Lacey, 'The Office for King Charles the Martyr in the Book of Common Prayer, 1662-1685', The Journal of Ecclesiastical History 53, no. 3 (2002): 519.
} 
The real end of religion was to be achieved by constant endeavour to repent. In his Principles and Practices, Edward Fowler explained that 'the grand designe of the Gospel ... is to make men good: not to intoxicate their brains with notions, or furnish their heads with a systeme of opinions; but to reform mens lives, and purifie their natures'. ${ }^{34}$ Simon Patrick provides a good example of the latitudinarian version of individual reformation. In one sermon, he asserted that the 'blessed work of Reformation of Religion' was brought about 'by the long study, and labours, and prayers, and sufferings, and blood of many of thy faithful servants' ${ }^{35}$ Repentance was key element to the reconciliation between human beings and God. It was reasonable for him to think that repentance would prevent the 'judgment of God' which inflicted punishments on them for their sins. It followed that the people should afflict and chastise themselves 'in a contrite manner, with Fastings and Mournings, and bewailing of their Sins, and other Humiliations: that so there might have been no need of Gods inflicting punishments upon them for their reformation' ${ }^{36}$

The theme of repentance recurred on several occasions, especially on Ash Wednesday, Easter, Advent, and other fast days, in the pulpits. On these days Anglicans endeavoured to preach sermons on the spiritual degeneration of their times and the necessity of repentance. The exhortation of repentance and imminence of God's judgment upon sinners much echoed in the fast day. On Ash Wednesday, 27 February in 1661, he heard a sermon by the Bishop of London concerning 'charity and forgiveness'. On another Ash Wednesday, 2 March 1682, Evelyn wrote that he went to church where a vicar preached on Proverbs, 'showing what care and vigilance was required for the keeping of the heart upright'. ${ }^{37}$ John Evelyn's diary reveals that sermons of fast days were full of the fear of divine wrath and damnation. Needless to say, preaching in pulpits in the fasting day was filled with the tone of caution and painfulness of forthcoming divine punishment. The fear of the frustrating future was amplified in many sermons, and tracts. Sermons preached on fasts, in particular, concentrated upon the warning of divine judgment on a nation. The

\footnotetext{
34 Edward Fowler, The Principles and Practices of Certain Moderate Divines of the Church of England (London, 1670), 1:18.

35 Patrick, A Private Prayer to Be Used in Difficult Times (London, 1687), sig. A4r.

${ }^{36}$ Patrick, A Treatise of Repentance and of Fasting, Especially of the Lent-Fast (London, 1686), 43.

37 John Evelyn, Diary and Correspondence of John Evelyn, F. R. S. To Which Is Subjoined the Private Correspondence between King Charles I and Sir Edward Nicholas and between Sir Edward Hyde, Afterwards Earl of Clarendon, and Sir Richard Browne, ed., William Bray (London: George Routledge, n.d.), 239, 392.
} 
latitudinarian clergy were not different from the mainstream of Anglican churchmen in preaching on God's warning of punishment for the impenitent. ${ }^{38}$

It is remarkable that in their sermons the latitudinarians asserted the close relationship between human sins and national destiny in history. They believed that God had endured human sins for so long before he decided on the destruction of a particular nation. While God warned the people of Israel of ruin and destruction, Tillotson said, his intent was to invite and urge them to repentance. ${ }^{39}$ Like Tillotson, other latitudinarians easily gave a familiar example of the city of Nineveh from the Old Testament. 'To this City', explained Stillingfleet:

God sends a Prophet to let them know how near they were to destruction, that they had but forty dayes time to turn themselves in. This was a strange and unexpected alarm to them, given by a strange Prophet after a peremptory manner to a people unacquainted with such messages. ... Yet so great was the apprehension they had of the just desert of their sins, that the People of Nineveh believed God and proclaimed a Fast, and put on Sackcloth, from the greatest of them even to the least: and they cryed mightily to God, and turned from their evil ways: ... His Wisdom in leading them to repentance; his Goodness in forbearing to punish after so great provocations. What encouragement doth God hereby give to others to repent, when Nineveh was rescued from the very brink of destruction by it? ${ }^{40}$

The story of Nineveh was an exemplar of national repentance. In contrast to this penitent pagan city, preachers explained how the stubbornly impenitent Jews had to suffer divine punishment. The Jewish historian Josephus, said Tillotson, was a witness of the siege of Jerusalem and famine to come after it both of which were God's 'vengeance'. Tillotson was convinced that this tragedy happened due to the

\footnotetext{
38 Tillotson, 'Sermon XXXVII: The Way to Prevent the Ruin of a Sinful People, a Fast-Sermon Preached before the Lord-Mayor', in Sermons on Several Subjects and Occasions, vol. 3 (London, 1757); 'Sermon XIII: The Nature of Benefit of Consideration', in Sermons on Several Subjects and Occasions, by the Most Reverend Dr. John Tillotson, Late Archbishop of Canterbury, vol. 1 (London, 1757); Burnet, A Sermon Preached before the Right-Honourable the Lord-Mayor and Aldermen of the City of London, at Bow-Church, September 2, 1680. Being the Anniversary Fast for the Burning of London; Patrick, Anglicae Speculum: A Glass That Flatter Not, Presented to a Country Congregation at the Late Solemn Fast, April 24, 1678 (London, 1678); Stillingfleet, A Sermon Preached on the Fast-Day November 13, 1678 at St. Margarets Westminster before the Honourable House of Commons. For mainstream Anglican preaching on the same theme see Lacey, 'The Office for King Charles the Martyr in the Book of Common Prayer, 1662-1685', 513-19; The Cult of King Charles the Martyr (Woodbridge: Boydell Press, 2003), 50, 131-37; Spurr, "“Virtue, Religion and Government": The Anglican Uses of Providence', in The Politics of Religion in Restoration England, eds., Tim Harris, Paul Seaward, and Mark Goldie (Oxford: Blackwell, 1990).

39 Tillotson, 'Sermon XXXVII: The Way to Prevent the Ruin of a Sinful People, a Fast-Sermon Preached before the Lord-Mayor', 54.

${ }^{40}$ Stillingfleet, A Sermon Preached on the Fast-Day November 13, 1678 at St. Margarets Westminster before the Honourable House of Commons, 24-5.
} 
'prodigious height of impiety and wickedness', and he stoked up feeling by citing the Jewish historians' lament: 'O miserable city! What didst thou suffer from the Romans, though at last they set thee on fire to purge thee from they sins, what is to be compared with those miseries which thous hast brought upon thyself? ${ }^{41}$ For the moderate Anglicans many biblical stories taught what awaited the nation that did not repent at the end. As God commanded the Israelites to remember the time when they were in captivity under Egypt, Burnet argued, Englishmen must never forget the providence of God. ${ }^{42}$ In this point, the scripture not only told Jewish history but also suggested the continuity of the providential course of human history, especially, in English history. Patrick found no difference between the English and the Jewish situations in terms of the providential world-view, saying that 'His words and those of Moses are verified again in this Kingdom' ${ }^{43}$

However, there was a question of how individual sin could impact on national destiny. The ambiguous relationship between individual vice and providential judgment on a nation seems strange to the modern mind. Stillingfleet tried to explain the way in which daily vices made God punish a nation by employing a pathological metaphor. 'When men daily and insolently break the Laws of God', described Stillingfleet, 'wickedness spreads like leprosie, and infects the whole body; when vices become so notorious that they are a reproach and a by-word to Neighbour Nations; these are the sings and tokens of Nation quilt'. ${ }^{44}$ This explanation would not be satisfactory to us. It is obvious, nevertheless, that the latitudinarians emphasised national repentance as much as individual salvation. If sins continued, they warned, the result would not be individual miseries but national tragedy.

The latitudinarians did not divert the discourse of repentance into a detailed analysis of how individual efforts might turn God's anger away from the whole nation. For them, human actions for repentance were the only chance to avoid God's punishment. Patrick, for example, made it clear that 'Fasting is every way a means to

\footnotetext{
41 Tillotson, 'Sermon XXXVII: The Way to Prevent the Ruin of a Sinful People, a Fast-Sermon Preached before the Lord-Mayor', 67-71.

${ }^{42}$ Burnet, A Sermon Preached before the Right-Honourable the Lord-Mayor and Aldermen of the City of London, at Bow-Church, September 2, 1680. Being the Anniversary Fast for the Burning of London, 8-9.

${ }^{43}$ Patrick, Anglicae Speculum: A Glass That Flatter Not, Presented to a Country Congregation at the Late Solemn Fast, April 24, 1678, 16; Stillingfleet, A Sermon Preached on the Fast-Day November 13, 1678 at St. Margarets Westminster before the Honourable House of Commons, 13; Tillotson, 'Sermon XXXVII: The Way to Prevent the Ruin of a Sinful People, a Fast-Sermon Preached before the Lord-Mayor', 72-3.

${ }^{44}$ Stillingfleet, A Sermon Preached on the Fast-Day November 13, 1678 at St. Margarets Westminster before the Honourable House of Commons, 16.
} 
obtain favour with God, for the averting of his anger, from our selves, or from the Nation where we live'. Instead of explicating the relationship between individual repentance and its impact on the nation, he made use of the Scriptures to show that biblical examples revealed that God withdrew his anger over the people who fasted for their sins. 'As we may gather from the Ninevites', he wrote,

who proclaimed a Fast, and put on Sackcloth from the greatest of them even to the least; hoping God would turn from his fierce anger denounced against them, if they turned every man from his evil way; for which, by these Humiliations, they professed themselves heartily sorry. ${ }^{45}$

Another example in Matthew 11:22 showed many countries did something similar when seeking divine mercy. 'If Tyre and Sidon', Patrick argued, 'had enjoyed such means of being good, as Chorazin and Bethsaida had, they would have Repented long ago in Sackcloth and Ashes: that is, humbled themselves with Fasting, after the example of the Ninevites; for on such solemn occasions they put on Sackcloth and threw Ashes on their heads; which usually accompanied Fasting, as Fasting did Prayer to God for mercy. ${ }^{46}$

National repentance was understood in the context of the process of reformation. Reformation of religion required the nation and its leaders to amend their lives. In the 1690s, in particular, the supporters of godly reformation led by the monarch acclaimed King William and Queen Mary for their religious piety. The latitudinarians did not hide their expectations of peace and prosperity under these two monarchs. Stillingfleet claimed that 'under the providence of almighty God, and the conduct of two such excellent princes as he hath now blessed us withal: the one so brave and valiant, and both of them so wise, so good, so religious, we may at last arrive at a firm establishment, and become "like mount Zion that cannot" be moved'. ${ }^{47}$ After the pious princes, the emphasis on repentance remained undiminished. After the Queen's death, Burnet wrote that 'the deep Sense that she had of the Guilt and Judgments that seemed to be hanging over us' ${ }^{48}$

The use of providence was not to bring the people to repentance. In fact, the rhetoric of providence was bound to point to the future. The hope for the future was

\footnotetext{
${ }^{45}$ Patrick, A Treatise of Repentance and of Fasting, Especially of the Lent-Fast, 95.

${ }^{46}$ Ibid., 96.

${ }^{47}$ Ibid., 78-9.

48 Burnet, Essay on the Memory on the Memory of the Late Queen (London, 1695), 134.
} 
an essential part of providential narrative. Stillingfleet, for example, made his sermon directed to the final vision of God's providence. 'Blessed be that God', he praised, 'that God who hath hitherto defeated all the secret, and subtle, and cruel designs of his and our Churches enemies; and hath given us the liberty and opportunity of this day to meet together to implore the continuance of his favour and mercy towards us' ${ }^{49}$ Stillingfleet insisted that divine providence would be severe to the Christians who were ungrateful to God but they might be happy under 'his Government if they did sincerely keep to their established Religion and obey the laws of God' ${ }^{50}$

Their excessive emphasis on repentance and human duty in this world seems unnecessary in a Christian society. This shows, however, how far the seventeenthcentury clergy worried about the impotence of reformed Christianity. In a sermon, Tillotson lamented that

How few are there among those who profess to believe the Gospel, who believe it in this effectual manner, so as to conform themselves to it? The Faith which most Christians pretend to, is merely negative; they do not disbelieve the Gospel, they do not consider it, nor trouble themselves about it, they do not care nor are concerned whether it be true or not; but they have not a positive belief of it, they are not possest with a firm perswasion of the truth of those matters which are contained in it. ${ }^{51}$

The Anglicans like Tillotson viewed theirs as an age of imperfect reformation. As John Sharp reminded his congregation in a Lent sermon, those who had rebelled against God would end up suffering 'the gnawings of a Worm that never dies', and 'everlasting Burnings' unless they would get themselves involved in 'a speedy reformation'. 52

The latitudinarians thought that repentance was a necessary step towards the benefit of God's mercy and the accomplishment of God's providence. Why were the 'papists' and atheists such threats to England? Because the English people, Tillotson diagnosed, were still impenitent. In the same sermon, Tillotson saw the present condition of the Protestant church 'sunk and declin'd in her glory, and reduc'd into a very narrow compass'. The church was described as the daughter of Sion, a cottage

\footnotetext{
49 Stillingfleet, A Sermon Preached on the Fast-Day November 13, 1678 at St. Margarets Westminster before the Honourable House of Commons, 2.

${ }^{50}$ Ibid., 10.

51 Tillotson, 'The Necessity of Repentance and Faith', in Several Discourses of Repentance, ed., Ralph Barker (London, 1700), 18-9.

52 John Sharp, A Sermon Preached at White-Hall in Lent on Friday March 20, 1684/5 (London, 1685), 24.
} 
in the vineyard, and a besieged city which implied the Protestant church in danger. ${ }^{53}$ However, this was the intention of God's judgement. Tillotson said that 'the design of God's goodness and long-suffering, and forbearance towards us, is, to lead us to Repentance'. Here Tillotson showed a way to escape divine punishment: 'repentance' and 'real Reformation of our lives'. These actions would make God so pleased that He would turn away anger from the people and stretch out His hand for their deliverance. ${ }^{54}$ Tillotson urged the audience, accordingly, to humbly beg of Christ. For them repentance was an antidote to take away the power of sins. They shared the belief that genuine conversion to Christ and salvation were guaranteed by repentance. $^{55}$

\subsection{Human Capacity for Moral Reform: Latitudinarian Soteriology}

The apocalyptic theme of national sins and divine judgment gained popularity throughout the Restoration. Conformists and Nonconformists alike were preoccupied with the idea that England's affairs were under God's direct governance. It was acknowledged among seventeenth-century English Protestants that repentance was essential to human salvation and that divine providence directly intervened in national and individual affairs in the form of blessings and punishments. So, although conformists and Nonconformists, or other Calvinist denominations, seem to agree on questions of human salvation in broad terms, there was a deep difference between Anglicans and Calvinists in understanding how to gain salvation under God's providence. The significant difference between the two theological streams was the extent to which human capacity contributed to salvation.

Basically, Calvinist soteriology was based on a firm belief in predestination. Calvinists assumed that God's particular providence was related to His predestined people. ${ }^{56}$ Calvinists believed that those who would be saved and redeemed from

\footnotetext{
53 Tillotson, 'Sermon LX: Of Constancy in the Profession of the True Religion', in Sermons on Several Subjects and Occasions, by the Most Reverend Dr. John Tillotson, Late Archbishop of Canterbury, vol. 5 (London, 1757), $23-4$.

${ }^{54}$ Tillotson, 'Sermon LIX: Of Constancy in the Profession of the True Religion', in Sermons on Several Subjects and Occasions, by the Most Reverend Dr. John Tillotson, Late Archbishop of Canterbury, vol. 5 (London, 1757), 5; Tillotson, 'Sermon LX: Of Constancy in the Profession of the True Religion', 30.

${ }_{55}$ Patrick, Mensa Mystica; or a Discourse Concerning the Sacrament of the Lords Supper (London, 1660), 42122; Burnet, A Sermon Preached at the Chappel of the Rolls, on the Fifth of November, 1684. Being Gun-PowderTreason-Day (London, 1684), 8-9.

${ }^{56}$ David Manning, "Anti-Providentialism as Blasphemy in Late Stuart England: A Case Study of "the Stage Debate", Journal of Religious History 32, no. 4 (2008): 424.
} 
eternal misery were predestined by divine providence. John Calvin was an observer of God's general providence. It has been acknowledged that in relation to divine providence Calvin's concern was with the relationship between divine intervention and Calvinist doctrine of predestination. He believed that calling and the grace of God could not be resisted by those who were once chosen by God. This understanding of predestination was manifest in the doctrine of irresistible grace which undermined human free will. Ronald J. VanderMolen shows that Calvin believed that providence was deterministic, and that every particular event happened as planned by God. ${ }^{57}$ In his Institutes of the Christian Religion, Calvin asserted that 'there is nothing in this providence, which they call universal, to prevent all the creatures from being moved contingently, or to prevent man from turning himself in this direction or in that, according to the mere freedom of his own will'. ${ }^{58}$ For this reason he excluded the possibility of 'the contingency which depends on human will'. 59

Calvin's understanding of providence underscored a notion of the depravity of human knowledge. He argued that a human being was not able to understand the design of divine providence due to their spiritual corruption. Thus, for him, the completion of human knowledge could be made through pure faith. ${ }^{60}$ Consequently, Calvinist predestination discounted any human capacity to discern divine providence and the human free will to act voluntarily for good or bad. The doctrine of predestination was rooted in its fundamental premise: divine providence was an obvious proof that there were those who were chosen to be saved and redeemed from everlasting punishment.

Following Calvin's theological discourse about predestination, the prominent Nonconformists continued to develop Calvinist soteriology in the early seventeenth century. This can be seen in a series of prominent publications: Lewis Bayly's handbook The Practice of Pietie (1613), the Westminster Confession of Faith and Larger Catechism (1647), Thomas Goodwin's A Child of Light Walking in Darkness

\footnotetext{
57 Ronald J. VanderMolen, 'Providence as Mystery, Providence as Revelation: Puritan and Anglican Modifications of John Calvin's Doctrine of Providence', Church History 47, no. 1 (1978): 30.

58 Jean Calvin, Institutes of the Christian Religion, trans., Henry Beveridge, vol. 1 (Edinburgh: T. \& T. Clark, 1863), chap. 16:175.

59 Ibid., $1: 180$.

60 VanderMolen, 'Providence as Mystery, Providence as Revelation: Puritan and Anglican Modifications of John Calvin's Doctrine of Providence’, 32.
} 
(1636) and Edmund Calamy's The Godly Mans Ark (1657). ${ }^{61}$ Bayly, for example, was convinced that good works were encouraged and true Christians must prove themselves to be saved by works of piety. In contrast to Anglicans, he stressed that the elect must obey the Ten Commandments to glorify God and to show thankfulness for their redemption. For Bayly, the practice of piety was followed by the operation of God's grace for the elect. There had been, thus, a problem 'of balancing the doctrine of grace with practice, of giving due weight to the latter while not allowing it to derogate from the former', and this was a subject to controversy with conformist polemicists. $^{62}$ It was true that there were moderate Nonconformists who were always endeavouring to avoid any extreme argument which could be derived from their theology. They expected that the doctrine of predestination would encourage Christians towards the practice of good works as they would be evidence of their profession of a fruitful faith. John Goodwin (1594-1665), Independent preacher, for example, claimed that justification could not be made without human works, even though he held the Calvinist doctrines of justification by faith and salvation by grace. ${ }^{63}$ This kind of soteriology was under attack of other Calvinists who supported the absolute predestination.

Yet for Anglican clergy the Nonconformist doctrine of the grace of God was troubling. It left the necessity of human work in the process of redemption unclear. There was little dispute between Anglicans and Nonconformists over the doctrine that God's grace was necessary for men to gain access to salvation prior to any kind of human effort. However, there was a distinction between their emphases. Puritans placed more emphasis upon the omnipotence of God's grace in the process of salvation. For Anglicans, the most striking difference was that Puritans put a much greater emphasis on absolute predestinarian language which was of limited or little appeal to the majority of Anglicans. ${ }^{64}$ In this point, Anglican soteriology sounds similar to Arminius' understanding of grace. Arminius contended that repentance was caused by God's Word and Spirit. But he asserted that God's grace could be

\footnotetext{
${ }^{61}$ Rivers, Reason, Grace, and Sentiment: A Study of the Language of Religion and Ethics in England, 1660-1780, Vol. 1, Whichcote to Wesley, 12.

${ }^{62}$ Ibid., 13.

63 John Coffey, John Godwin and the Puritan Revolution: Religion and Intellectual Change in Seventeenth Century England (London: Boydell Press, 2006), 232.

64 J. Sears McGee, The Godly Man in Stuart England: Anglicans, Puritans, and the Two Tables, 1620-1670 (New Haven: Yale University Press, 1976), 57-9.
} 
rejected by human will. ${ }^{65}$ The fierce rejection of irresistible predestination was connected with a question human free will. Anglicans doubted the validity of Calvinist utter reliance on faith in the Scriptures. For them a problem remained unsolved: where was free will to act morally good placed in this account of salvation? If there was no place for human works in the history of salvation it would inevitably diminish the value of moral responsibility. ${ }^{66}$

Numerous Anglican works dealt with the problem of the relationship between human free will and divine grace. In England the theological tradition that adopted both Socinian and Arminian views of salvation was shaped by the Great Tew circle. Henry Hammond, for example, argued that Christ was sent to men as a moral teacher so that they would be able to reach what God designed men to be. ${ }^{67}$ Hammond's $A$ Practical Catechisme (1644) and two handbooks, Jeremy Taylor's Holy Living (1650) and the anonymous Practice of Christian Graces (1658), better known as The Whole Duty of Man written by Richard Allestree, set forth a view opposed to Calvinist soteriology during the English Civil War and the years of Interregnum. Anglicans who refused to conform to the Cromwellian church in the 1650s and were ejected from their livings under the pressure of Puritan-dominant policy, were also often the leading theological critics of Calvinist doctrine. Hammond, for example, repudiated Calvinist doctrine when he asserted that the beginning of a new life preceded justification. In other words, repentance and return must be conducted before God would pardon a human being. Holy living then followed. In a letter to Robert Sanderson, Hammond opposed the idea of irresistible grace, and then asserted that salvation was only attainable through personal reform. ${ }^{68}$

Hammond rejected the Calvinist doctrine of justification because 'this is apt to have an ill influence on practice, and therefore I thought fit to prevent it'. He, consequently, thought sanctification was followed by justification. For him it was true that God would not pardon until 'we in heart reform and amend', and the individual 'abandons the sinnes of the Old man'. In his view, what should be stressed

\footnotetext{
65 J. V. Fesko, Beyond Calvin: Union with Christ and Justification in Early Modern Reformed Theology 15171700 (Göttingen: Vandenhoeck \& Ruprecht, 2012), 273-74.

${ }^{66}$ Peter Harrison, "Religion" and the Religions in the English Enlightenment (Cambridge: Cambridge University Press, 1990), 23.

${ }^{67}$ For Hammond's soteriology see Sarah Mortimer, Reason and Religion in the English Revolution the Challenge of Socinianism (Cambridge: Cambridge University Press, 2010), 127-37.

${ }^{68}$ Henry Hammond, Charis Kai EirēeNē, or, a Pacifick Discourse of Gods Grace and Decrees (London, 1660); W. M. Spellman, The Latitudinarians and the Church of England, 1660-1700 (Athens, Georgia: University of Georgia Press, 1993), 97.
} 
was the role of human free will to commence moral reform. It was from good and free will that reform could be begun. In short, the process of salvation Hammond described fell into several parts: repentance which the sinner would do by 'a New Covenant' to which the death of Christ would bring the sinner, 'faithfull resolutions of new life', justification, and performance of good resolutions. ${ }^{69}$

The substantial principles of latitudinarian soteriology were already seen in the Anglican works of devotion published during the middle of the seventeenth century. It is suggested that the latitudinarians, along with other Anglican divines, followed the key devotional works of Anglican forerunners. Latitudinarians' soteriological foundations were established by Anglican moral thought developed by Hooker, the Great Tew Circle including Chillingworth, the Cambridge Platonists and Jeremy Taylor. ${ }^{70}$ They commonly emphasised the individual decision and responsibility for their moral behaviour. They all rejected the premise that salvation happened no matter what human works were performed. Their commitments to moral teaching formed the main part of Anglican moral theology.

The seventeenth-century latitudinarians did not underestimate the importance of God's grace. Rather, like other Protestants, they consistently emphasised the necessity of God's grace. As Tillotson admitted, Christians have been enabled to do good works by divine grace. Tillotson thought that grace and good works could not be separated: the grace of God would encourage the people to do virtuous behaviours. ${ }^{71}$ In Private Prayer to be used in Difficult Times (1687), Patrick also believed that grace given by Christ 'whose Agony and Bloody sweat, his Cross and Passions, Resurrection and Intercession' delivered salvation for human being. ${ }^{72}$

The latitudinarian Anglicans preferred a moderate way in the discussion of faith and works. While they agreed on the necessity of the grace of God for human salvation, they tended to stress human efforts to do morally good. Fowler wrote that 'we must go in a middle way, and avoid the extremes on both hands.' In doing so, he went on to argue that 'the new Covenant is conditional' and 'faith is the condition of

\footnotetext{
${ }^{69}$ Hammond, Practical Catechisme (London, 1646), 49-50. For analysis of Hammond book, see Rivers, Reason, Grace, and Sentiment: A Study of the Language of Religion and Ethics in England, 1660-1780, Vol. 1, Whichcote to Wesley, 18, 20-1.

70 Jeremy Schmidt, Melancholy and the Care of the Soul: Religion, Moral Philosophy and Madness in Early Modern England (Aldershot: Ashgate, 2007), 81; Thomas Palmer, Jansenism and England: Moral Rigorism across the Confessions (Oxford: Oxford University Press, 2018), 242.

${ }^{71}$ Tillotson, 'Sermon XXVI: The Blessedness of Good Men, after Death', in The Works of the Most Reverend Dr. John Tillotson, vol. 4 (Dublin, 1739), 414.

72 Patrick, A Private Prayer to Be Used in Difficult Times, sig. A3v.
} 
it'. Regardless of the worrisome charge of espousing the Catholic doctrine of justification by works, Fowler insisted on the necessity of working faith by explaining that 'works signifie sincere obedience to Christs Gospel', and further on, 'faith justifieth our persons, and works our faith' ${ }^{73}$ In Fowler's work, working faith was defined to imply the importance of human works. Like his Anglican predecessors, he thought working faith could be carried out in co-operation with grace. Patrick summed up his emphasis on virtuous life through his brief conclusion that 'Mankind must use their sincere endeavours to make themselves happy, through the knowledge of Jesus Christ; or else they may become more miserable by that very means ... we must contribute our pains and labour to bring it about; by a faithful improvement of those means which God affords us of Knowledge and of Grace' ${ }^{74}$ It was obvious, thus, that they conceived holy living to be central to religion and believed that true Christians must be justified by their works. There was a good analogy describing the relationship between grace and works. In his sermon, Tillotson made use of the biblical image of the vine and branches to visualise it.

As there is a natural vital Union between the Vine and the Branches, so is there a spiritual vital Union between Christ and the true Christians; and this Union is the cause of our Fruitfulness in the works of Obedience, and a good life. ${ }^{75}$

Tillotson, like Fowler, thought that fruit could be the touchstone to check whether the believer was justified or not. He warned that 'Husbandman' would 'lop off, and take away those who did not 'bring forth Fruit', because they were deemed as unprofitable and dead Branches'. ${ }^{76}$ To avoid this separation from Christ, Christians were obliged to produce the fruits of obedience and a good life.

For all the moderate Anglicans' efforts to dodge the criticism of putting much more weight on human work than on grace, it was inevitable that Nonconformist adversaries would immediately criticise them. The Anglican approach to the doctrine of justification assumed that God had given men free will to repudiate sin and make a resolution for new life, or to refuse to accept God's grace. Along with the members of the Great Tew circle and Cambridge Platonists, Benjamin Whichcote, Ralph

\footnotetext{
${ }^{73}$ Fowler, The Principles and Practices of Certain Moderate Divines of the Church of England, 188-89.

${ }^{74}$ Patrick, A Sermon Preached at St. Paul's Covent-Garden on the First Sunday in Lent (London, 1689), 26.

75 Tillotson, 'Sermon XV: The Necessity of Supernatural Grace, in Order to a Christian Life', in Several Discourses of the Life, Suffering, Resurrection, and Ascension of Christ, ed., Ralph Barker (London, 1701), 442.

${ }^{76}$ Loc. cit.
} 
Cudworth, William Chillingworth, and the like, the latitudinarians advanced an optimistic view of human free will which could choose either to obey the way of salvation or follow the path of damnation. This view of the ability of human effort to influence salvation was open to the accusation that it tended to diminish the power of God's saving grace applied through the sacrifice of Christ. ${ }^{77}$ In the eyes of some, Jeremy Taylor's arguments, for example, insinuated Socinianism. Taylor did not accept the view of men's moral ability as being damaged from Adam's fall, and this position was manifest in Socinus' understanding of original sin. Taylor's insistence upon individual responsibility and choice could not remove suspicion that the moderate Anglicans were tarred with Socinianism. ${ }^{78}$ Churchmen like Stillingfleet and Tillotson asserted the doctrine of Christ's saving role in human salvation, but it was in line with Fowler that they admitted the individual's responsibility for his own salvation. To Nonconformists this appeared simply as 'Arminian' or 'Socinian' theology. ${ }^{79}$ The latitudinarian view of righteousness provided a reason for the opponents' accusation against them of being 'moral preachers' or advocates of moral theology. Nonconformists labelled the latitudinarians as 'Rational Preachers' or 'Moral Preachers.' The latitudinarians were even vilified for alluding to Catholic doctrine of justification by works. ${ }^{80}$

The latitudinarians tried to counter these accusations of Socianianism and a tendency towards natural religion. They did not want to be thought to be sympathetic with those alleged to deny the divinity of Christ and to elevate reason and morality above faith. Faith, Tillotson said, was the great principle of religion: 'without Faith a Man cannot be Religious'. What Tillotson really emphasised was that true faith was based on reasonable understanding of Christ. 'We should trust in him', Tillotson explained, firstly because God was 'infinitely Wise and Powerful as well as Good, and secondly, God was 'the Original Pattern of all Excellency and Perfection'. Reasonableness and perfection are put together in his idea of divine nature. What was left to the believer, for Tillotson, was to 'imitate the Perfection of the Divine

\footnotetext{
77 McGee, The Godly Man in Stuart England: Anglicans, Puritans, and the Two Tables, 1620-1670, 209.

${ }^{78}$ For the theological link of Taylor's view of morality to Socinus', see Mortimer, Reason and Religion in the English Revolution the Challenge of Socinianism, chap. 5.

79 Spurr, The Restoration Church of England, 1646-1689, 256.

${ }^{80}$ Fowler, The Principles and Practices of Certain Moderate Divines of the Church of England, 103, 116; Rivers, Reason, Grace, and Sentiment: A Study of the Language of Religion and Ethics in England, 1660-1780, Vol. 1, Whichcote to Wesley, 37.
} 
Nature, and to endeavour to be as like God'. ${ }^{81}$ It was significant to find that Tillotson was conscious of the danger of Socinianism so he kept his rational defences of Christianity away from Socinianism, stressed his adherence to orthodox doctrine of revealed religion, and admired rational religion in a different way from Socinianism. Like Tillotson, many latitudinarian clergy thought the reasonableness of religion could be a foundation for the campaign for holy living. Fowler defined reason as power 'whereby men are enabled to draw clear Inferences from evident Principles'. He continued to explain that the latitudinarian churchmen 'demonstrate the reasonableness of the Precepts of the Gospel', and 'prove that there are those self-evident Principles, from whence what the Gospel requires may be inferred to be our duty'. 82

Burnet denounced the way in which the Roman Church required their followers to repent. Undergoing the law of the church, 'the Vulgar do really imagine', he criticised, that they could 'buy and sell with Almighty God', by penance 'imposed' by their Confessour'. It was nothing but a false doctrine nourishing pride and selflove and it detracted 'from the value they ought to set on the blood of Christ' ${ }^{83}$ Protestant divines all agreed that true repentance was not just contrition or utterance of confession. The conception of repentance must retain a good Christian life. Stillingfleet believed that no man could be saved without 'true repentance', and that it did not 'lye merely in contrition for sins'. Basically the moderate clergy in the Church of England were engaged in a theological battle against the structure of Catholic thought. After the Council of Trent, the Jesuits, in particular, were inclined to separate moral and ascetical theology, 'the one occupied with the question of the legality or illegality of human acts, and the other concerned with spiritual progress and holiness'. ${ }^{84}$ For Anglicans this teaching, consequently, could diminish the importance of the whole spiritual tone of Christian practice. ${ }^{85}$ The rites for penance in the Catholic Church seemed to destroy the necessity of good works because Catholics could be declared to be in a state of salvation if they had only a 'bare

81 Tillotson, 'The Efficacy, Usefulness, and Reasonableness of Divine Faith', in Fifteen Sermons on Various Subjects, ed., Ralph Barker (London, 1703), 146, 151-52.

${ }_{82}$ Fowler, The Principles and Practices of Certain Moderate Divines of the Church of England, 70.

83 Burnet, The Mystery of Iniquity Unveiled in a Discourse, Wherein Is Held Forth the Opposition of the Doctrine, Worship, and Practices of the Roman Church (London, 1673), 53.

${ }^{84}$ Henry R. McAdoo, The Structure of Caroline Moral Theology (London: Longmans, Green and Co, 1949), 10. cited from Spellman, The Latitudinarians and the Church of England, 1660-1700, 113.

${ }^{85}$ Spellman, The Latitudinarians and the Church of England, 1660-1700, 113-14. 
contrition' for sins and confessed them to the priest so that they would be absolved. ${ }^{86}$ The seventeenth-century clergy also worried about the Nonconformist version of repentance. For the puritan, the conversion of the soul was a crucial process towards salvation. In this case, repentance could be seen as a mere phase or passage on the longer route to salvation. The Anglican divines were concerned that this would allow people to continue their sins and to defer repentance until they would feel the necessity of it. ${ }^{87}$ No matter how much the puritans struggled to keep a balance between the emphasis on human duty and the theory of justification, the Anglican divines saw this way of righteousness as insufficient. Tillotson insisted upon an immediate transformation of belief and behavior since the fact that men were merely convinced of the necessity of repentance could not enforce 'a present change'. For him 'men hope they may continue in their sins, and remedy all at last by repentance', but this was 'so great hazard in all respects that there is no venturing upon it'. Therefore, one ought to know that this day 'may be the last opportunity of making our peace with God,' and 'make haste out of this dangerous state as Lot did out of Sodom, lest fire and brimstone overtake us'. ${ }^{88}$

These Anglicans thought that the reasonable and proper way of repentance was somewhere in between Nonconformists' alleged 'Antinomianism' and Roman 'legalism'. Anglicans like Fowler readily blamed both Catholics and Calvinist dissenters for impiety. For him these rivalry groups were immoral simply because they overlooked the necessity for moral reform, not to mention their erroneous doctrines. 'Antinomians', Fowler condemned, 'hath so leavened the heads of the Vulgar, that they can scarcely hear of Christ's imputed righteousness, but they are ready to make an ill use of it' ${ }^{89}$ When it comes to Roman Church, Fowler condemned the practice of the 'Roman Church', was based upon 'an infallible Chair for the Judicial deciding of Controversies in Religion'. ${ }^{90} \mathrm{He}$ thought that the Catholic authority was so corrupted that its practices could not guarantee godly life. His prescription for a godly life was a middle way. 'A middle one betwixt the Calvinists and Remonstrants', Fowler advised, would save the people by

\footnotetext{
${ }^{86}$ Stillingfleet, A Discourse Concerning the Idolatry Practised in the Church of Rome (London, 1671), 156-57.

87 Spurr, The Restoration Church of England, 1646-1689, 293.

88 Tillotson, 'Sermon XIII: The Nature of Benefit of Consideration', 311-12.

${ }^{89}$ Fowler, The Principles and Practices of Certain Moderate Divines of the Church of England, 130-31.

90 Ibid., 296-97.
} 
'distinguishing grace' which would elect them 'by virtue whereof they shall be'. ${ }^{91}$ In a 1687 sermon at Guildhall Chapel in London, Stillingfleet simply quoted a biblical verse of Colossians 2:6, 'As ye have therefore received Christ Jesus the Lord, so walk ye in him', in order to illustrate what the Christians need to do for eternal happiness. The meaning of 'walking in him', Stillingfleet explained, referred to two obligations lying on the Christians, the one to 'keep stedfast to that Faith which they first received, without being seduced from it by the Arts of Deceivers, who were then busie among them', the other to 'live according to it, by making that Faith the Principle of a Christian Life'. ${ }^{92}$

When these Anglican divines discussed repentance, they tried to show that to repent was to change and adjust one's whole life to the principles of the scriptures. In other words, the process of repentance included human labour to amend behaviour. There was evidence, Tillotson admitted, in the scripture that many of the first Christians experienced the extraordinary and overwhelming power of God's grace and were reclaimed from their sins at once. However, 'in the usual and settled methods of God's grace evil habits are mastered and subdued by degrees, and with a great deal of conflict, and many times after they are routed they rally and make head again'. 93 Another example is Burnet's emphasis on the necessity of human efforts in relation to performing repentance. In his Exposition of the Thirty-Nine Articles (1700), he explicitly stated that 'the true Penance enjoined by the Gospel is the forsaking of Sin, and the doing Acts of Vertue'. He continued to explain that these acts are 'Fasting, Prayers and Alms-giving' which were proper means to 'raise us to this Temper'. ${ }^{94}$

Depicting the process of salvation as a long journey, Patrick stressed that the process of human salvation lasted the whole life long. Patrick's famous work, The Parable of the Pilgrim made use of the allegory of human journey to Jerusalem, depicting spiritual endeavours for salvation. Patrick did not omit the risk of a long and difficult journey. 'If you cherish not good thoughts of God in your mind', in the guide's words, 'all your Religion will degenerate into this spurious and baseborn

\footnotetext{
91 Ibid., 228.

92 Stillingfleet, 'Scripture and Tradition Compared in a Sermon Preached at Guild-Hall-Chapel, Novemb 27, 1687', in Fifty Sermons Preached Upon Several Occasions (London, 1707), 394.

${ }^{93}$ Tillotson, 'Sermon XIII: The Nature of Benefit of Consideration', 315.

${ }^{94}$ Burnet, An Exposition of the Thirty-Nine Articles of the Church of England (London, 1700), 282.
} 
devotion'. ${ }^{95}$ The true process of salvation necessarily entailed the pious works of Christians for the gradual improvement of human nature.

The latitudinarian focus on morality was associated with the theological rejection of the Calvinist doctrine of predestination and Catholic teaching on individual confession and absolution. Latitudinarians saw both claims as erroneous. The latitudinarians struggled to set forth their own soteriology distinctive from both Calvinist and Catholic arguments. They thought thereby that they attained moderate soteriology far from these two extremes. ${ }^{96}$ The latitudinarian divines were convinced that predestination and the insistence on inner faith would open the way to antinomianism while the demand for minimal actions for salvation undermined the prospect of human improvement religious edification and moral renewal. ${ }^{97}$ For them, religion played a role in promoting holy life through pastoral care, and this was the true end of religion.

\subsection{The Hope for the 'Perfection' of Human Nature}

Divine providence was believed to have a goal in the human world. Christians learned from scripture that God was watchful over all in the world and every individual he had created. God's judgments on his people had a key purpose: refining them to be wiser and more prudent. Many puritan preachers readily used the rhetoric of providential suffering intended for a discernible purpose. Throughout the seventeenth century, they used the metaphor of 'God's rod' to explain the severe punishments God meted out to the English people. Both Anglicans and puritans agreed that divine chastisement of sin and refinement of graces were necessary parts of human salvation. ${ }^{98}$ Both parties acknowledged that grace was essential for humans to turn away from sin but there was a difference in emphasis.

The age-old controversy over human perfectibility extends between two poles. Man could gain perfection himself by the exercise of his own free will, or man must be perfected only by means of God's overwhelming grace. Within Christianity, these two arguments had a long tradition reaching back to the dispute between Pelagians

\footnotetext{
95 Patrick, The Parable of the Pilgrim (London, 1665), 27.

96 Some historians argue that the latitudinarians' soteriological characteristic lay in their call for peaceful coexistence between the Arminian and the Calvinist traditions. See Stephen Hampton, Anti-Arminians: The Anglican Reformed Tradition from Charles II to George I (Oxford: Oxford University Press, 2008), 28-31.

97 Spellman, The Latitudinarians and the Church of England, 1660-1700, 113-14.

98 McGee, The Godly Man in Stuart England: Anglicans, Puritans, and the Two Tables, 1620-1670, 51.
} 
and Augustinians. The Irish monk Pelagius insisted on the ability of human beings to reach the status of human perfection in this life by reforming themselves. ${ }^{99} \mathrm{St}$ Augustine, in contrast, argued that because of human depravity human beings could not 'by their own efforts bring their souls to choose to serve God', in other words, participate in perfection of human nature. For him, human nature could be perfect after the resurrection of the body. ${ }^{100}$ The Reformation brought the issue to the fore again in Christian thought. Luther, influenced by Augustine, asserted that no one could be made perfect by his or her efforts. For him all people could do was loving and serving God by repenting their sins and having complete faith in God. Therefore, in his mind, there was no hope that men could reach perfection in earthly life. ${ }^{101}$

The 'perfection' of human nature was obviously not the same as the perfection of God or Christ. It was simply the limited 'perfection' that was attainable given the nature of human beings. All human beings are sinners and need Christ's sacrifice for their redemption. It was seen by many as a gradual process of improvement rather than a sudden and complete transformation of human nature. As we will see, it could involve the pursuit of 'holy living' or following the example of Christ. Protestants saw this as a process of 'edification', being built up as a living stone of the church, by a regime of piety and effort. Both Calvin and Luther taught that a man must prove his spiritual growth by his daily life. In this point, as John Passmore argues, there can be an interpretation that the notion of perfection is 'no longer thought of as a peculiar spiritual experience, to be sought after in the monastery or convent; it consists, rather, in the daily practice of morality'. He says, Calvin's view, inherited from the spirit of the Renaissance 'civic humanists', was carried into modern times when moral philosophers argued that 'the perfectibility of man consists in his capacity to be morally improved rather than in his capacity to enter into relation with some higher metaphysical Being, and this capacity is exhibited in his purely secular activities'. ${ }^{102}$ This interpretation suggests the waning importance of spiritual motives in the modern period.

\footnotetext{
99 John Arthur Passmore, The Perfectibility of Man (London: Duckworth, 1970), 94-6; Peter Harrison, The Fall of Man and the Foundations of Science (Cambridge: Cambridge University Press, 2007), 32-3.

${ }^{100}$ Harold G. Coward, The Perfectibility of Human Nature in Eastern and Western Thought (Albany: State University of New York Press, 2008), 62-3.

101 Passmore, The Perfectibility of Man, 14; Coward, The Perfectibility of Human Nature in Eastern and Western Thought, 70-1.

102 Passmore, The Perfectibility of Man, 157.
} 
There was a powerful presumption, at first sight, lying beneath latitudinarian moral theology. For the latitudinarians, the human performance of moral virtues was closely related to a philosophical concept of human perfection. In this context, they believed that temporal sufferings made men's spirits stronger so that they could approach perfection. Burnet, for example, deduced that another reason for the existence of God's punishment rested upon the creator's desire for human perfection. 'We forget that', he warned, 'the Saviour whom we follow was made perfect by sufferings; and that we become then truly his Disciples'. ${ }^{103}$ He insisted that making human nature perfect was one of great designs of Christianity. Clearest and divine rules worked out in order to drive men's souls to the 'highest perfection of their natures'. ${ }^{104}$ The latitudinarians dreamt of the perfecting of human nature through the course of providence. Similarly Tillotson exhorted 'diligence' and 'industry' with patience. Using the scriptural text Revelation 14:12, 'Here is the patience of the saints: here are they that keep the commandments of God, and the faith of Jesus', Tillotson said that 'all the good works which they have done', would go along with them and they would be 'receiving the comfort and reward of them. For Tillotson sufferings were designed to encourage the people to have 'fruit unto holiness'. ${ }^{105}$

Gradual progress towards perfection was described in Burnet's apocalyptic manner as one of the heads of the Christian religion. Burnet simply took for granted that the perfection of human nature was engrained in the original end of the Christian religion. ${ }^{106}$ Burnet's definition of perfection was imprecise, but it was obvious that he understood human perfection had something to do with morality. At this point his thought on human perfection corresponded with that of the Cambridge Platonists. When Henry More thought of the doctrine of human perfection, it came from the Cambridge Platonists' rejection of the Calvinist emphasis on men's fallen nature and incapability of being perfect in this life. ${ }^{107}$

\footnotetext{
103 Burnet, A Sermon Preached at the Chappel of the Rolls, on the Fifth of November, 1684. Being Gun-PowderTreason-Day, 10.

104 Burnet, The Mystery of Iniquity Unveiled in a Discourse, Wherein Is Held Forth the Opposition of the Doctrine, Worship, and Practices of the Roman Church, 7.

105 Tillotson, 'Sermon LXXIX: The Blessedness of Good Men after Death', 373-75.

106 Burnet, The Mystery of Iniquity Unveiled in a Discourse, Wherein Is Held Forth the Opposition of the Doctrine, Worship, and Practices of the Roman Church, 7-8.

107 Allison P. Coudert, 'Henry More, the Kabbalah, and the Quakers', in Philosophy, Science and Rreligion in England 1640-1700, eds., Richard Kroll, Richard Ashcraft, and Perez Zagorin (Cambridge: Cambridge University Press, 1992), 47.
} 
Latitudinarians consistently claimed that the life of Christ was a necessary guide to the pursuit of human perfection. Anglicans thought, in Clarendon's words, that God's grace enabled man to perform moral duties 'with reasonable perfection, and to endeavour with our utmost Power to please him'. ${ }^{108}$ The latitudinarians stressed the role of Christ in order to lead believers to imitate his life in conjunction with the help of God's grace and so to achieve salvation as the ultimate goal. Taylor provided the exemplary account of the imitation of Christ's life. Taylor thought of Christ as the best model of a moral teacher and explained that Christ's holy life needed to be imitated. 'God hath', Taylor wrote, 'predestinated us to be conformable to the image of his Son'. He continued to argue that 'the example of Jesus is so excellent, that it allures and tempts with its facility and sweetness, and that we are not commanded to imitate a life, whose story tells of ecstacies in prayer ... but a life of justice and temperance, of chastity and piety, of charity and devotion'. Taylor believed that Christians were obliged to be 'formed into the imitation of the life of the holiest Jesus', as 'the Spirit of God returns into us, not only by the efficacy of the imitation, but by the merit and impetration of the actions of Jesus'. 109

Taylor believed that the life of Christ must be rooted in the human heart. After penance, Taylor thought, 'the imitation of the Life of Jesus is a duty of that excellency and perfection, that we are helped in it not only by the assistance of a good and a great Example, ... but also by its easiness, compliance and proportion to us'. For him the whole of virtue and duties for a holy life was contained in the 'blessed Saviour'. ${ }^{110}$ It was through Christ that man could attain perfection. In this case, the reason why Christ was essential to human perfection was not only because of Christ's atonement for sin but because of His piety. ${ }^{111}$ Taylor's account of holy life drew partly on the medieval and Reformation tradition of piety, as Jessica Martin reveals, such as Nicolas Love's Myrrour of the Blessed Lyf of Jesu Christ (c. 1400) and William Perkin's The True Manner of Knowing Christ Crucified (1596). ${ }^{112}$ But it is also suggested that the relationship between holiness and progress by edification

\footnotetext{
108 Edward Hyde, 'Contemplations and Reflections Upon the Psalms of David', in A Collection of Several Tracts of the Right Honourable Earl of Clarendon (London, 1727), 535.

${ }^{109}$ Jeremy Taylor, 'An Exhortation to the Imitation of the Life of Christ', in Antiquitates Christianae or the History of the Life and Death of the Holy Jesus (London, 1684), v-viii.

110 Ibid., iii.

111 McGee, The Godly Man in Stuart England: Anglicans, Puritans, and the Two Tables, 1620-1670, 111.

112 Jessica Martin, 'Early Modern English Piety', in The Oxford History of Anglicanism, Vol. 1, Reformation and Identity, c.1520-1662, ed., Anthony Milton (Oxford: Oxford University Press, 2017), 401-2.
} 
was manifest in Taylor's imagination of Christ's life. In other words, the life of Christ provided an ideal image of holiness and perfection. This view of the relationship between Christ and human stood in marked contrast to the puritan view which saw an unbridgeable gap between the nature of Christ and human beings. The puritan version of thorough human depravity convinced Nonconformists that their Anglican opponents were rejecting God's saving grace.

Tillotson made it clear that moral virtues were what God expected human beings to attain. Tillotson stressed that 'Christians must be very eminent and conspicuous for ... the practice of Moral Duties' which were contained in 'the Law and the Prophets'. ${ }^{113}$ For him the main design of Christian religion was the perfection of human nature by binding men tightly with the moral principles of Christianity. His colleague, Burnet, remembered that Tillotson judged that the great Design of Christianity was the reforming Mens Natures, and governing their Actions, the restraining their Appetites, ... and sweetning their Humors' ${ }^{114}$ In one of sermons concerning morality and religion, Tillotson stressed human efforts to do good. In order to avoid religious errors and mistakes, which he perceived as being caused by Catholic infallibility in this sermon, Christians were required to endeavour to 'do the will of God' by which they could be 'qualified and disposed to make a right judgment of spiritual and divine things' ${ }^{115}$ For Tillotson a sincere endeavour to follow God's prescriptions in religious matters would secure men from mistakes. In doing so, Tillotson claimed, men were able to have 'a truer notion of God and divine things'. God's providence endowed those minds with divine perfection'. ${ }^{116}$ Tillotson described such men as more impartial in his search and enqury after truth ... not apt to be swayed and biassed by any interest or lust' in comparison with men who were 'governed by any earthly interest or design'. ${ }^{117}$ A good life, for Tillotson, was a necessary condition for reaching the perfect state of human beings. He wrote that 'a man may be a good man, and go to heaven notwithstanding a great many mistakes in

\footnotetext{
113 Tillotson, 'Sermon L: Christianity Doth Not Destroy, but Perfect the Law of Moses', in The Works of the Most Reverend Dr. John Tillotson, Late Archbishop of Canterbury, vol. 1 (London, 1717), 356.

114 Burnet, A Sermon Preached at the Funeral of the Most Reverend Father in God, John Tillotson (London, 1709), 15.

115 Tillotson, 'Sermon LXXXVII: Honesty the Best Preservative against Dangerous Mistakes in Religion', in Sermons on Several Subjects and Occasions, by the Most Reverend Dr. John Tillotson, Late Archbishop of Canterbury, vol. 6 (London, 1757), 42.

116 Loc., cit.

117 Tillotson, 'Sermon LXXXVII: Honesty the Best Preservative against Dangerous Mistakes in Religion', 46.
} 
religion about things not necessary'. 'While we are in this imperfect state', Tillotson continued,

"we know but in part, and see many things very imperfectly": but when we shall come into a more perfect state, "that which is imperfect shall be done away;" the light of glory shall scatter all those mists and clouds, which are now upon our understandings, and hinder us from a clear sight and judgment of things; we shall then see God, and other things, as they are; and be freed from all that ignorance, and those many chidish mistakes which we are liable to here below. ${ }^{118}$

Tillotson went on to discuss the future state awaiting true Christians. God's judgment on the sinner was heavy, but if one would believe the biblical truth which assured us of another life after this one, then future judgement will bring them to 'a state of everlasting happiness'. All that was left to men was to endeavour to attain the happiness which God promised by all means. Tillotson also dealt with psychological mechanism of human passion in God's design for happiness at the final stage of life. 'All men desire happiness', Tillotson added, 'and dread misery and destruction'. For him these mental motives appealed to human nature which was non-separable from them. Because they were based upon 'self-love' or 'self-preservation' which were deeply rooted in human mind and would last during one's life. ${ }^{119}$ As discussed earlier in this chapter, the latitudinarian idea of repentance revolved around two human emotions: one was the hope for the future happiness, the other was the fear of God's judgment. These two elements in penitential rhetoric exactly corresponded with the hope and fear men would have when facing providential destinations. In short, Tillotson went so far as to state simply that faith in promises of the scripture was nothing but the hope of eternal life and the belief in the fear of hell. Tillotson's sermon as moral guide exemplifies the tendency that man's primary duties were gradually directed towards man. In the eighteenth-century, the poet Alexander Pope similarly was convinced that 'true' self-love matched with the love of God by saying that 'God and nature linked the general frame, and bade self-love and social be the same'. ${ }^{120}$ The gradual shift in emphasis from God's grace to man's ability was manifest in Pope's answer.

\footnotetext{
118 Tillotson, 'Sermon LXXXVIII: Honesty the Best Perservative against Dangerous Mistakes in Religion', 56-7.

119 Tillotson, 'The Efficacy, Usefulness, and Reasonableness of Divine Faith', 155-56.

120 Alexander Pope, An Essay on Man (Dublin, 1745), 70, cited in Passmore, The Perfectibility of Man, 155.
} 
Tillotson's way of gaining eternal happiness rested upon true faith or selfpersuasion to live holy. In reputing the Catholic polemicist Bellamine's idea of faith, Tillotson argued that faith should be established on the basis of 'rational Principles', which consisted of two things, the principles of natural religion that there was a God, that man's soul was immortal, and that there were future rewards on the one hand, and on the other that the scriptures were the Word of God, that is divine revelation. Tillotson thus saw that faith in the perfect principles of Christianity could allow human beings to participate in the benefits of salvation. ${ }^{121}$ The latitudinarian clergy spoke of man's happiness which was thought to consist in perfecting his faculties, and the emphasis on moral duty was a corollary of their idea of religion's purpose.

The latitudinarian concept of human perfection suggests the dynamics of theological conflicts between confessional groups. The Anglicans' optimistic attitudes towards human perfection reflected their distinct concept of the role of religion. As has been argued, the Church of England held that God's grace was involved in everyone's salvation but human behaviour would play a more active part in striving to achieve salvation. This view of the relationship between Christ and human soul stood in marked contrast to the puritan doctrine of salvation that afforded no role to any kind of human actions in the process of salvation. ${ }^{122}$ Even if human capacity for morality was severely damaged, these Anglicans stressed that it would not be impossible to restore moral capacity.

\subsection{Anglican Moral Reform}

The latitudinarians' optimistic view of the perfectibility of human nature apparently led them to place more weight on Christ's moral teaching than upon divine grace. The latitudinarians' apocalyptic interpretation of the Restoration Church of England and their soteriology were the basis for a call for moral reform. They insisted that the penitence of the soul was not just a matter of confession but an entire conversion of human mind and soul. For most Anglicans, the Interregnum had been a period of religious and moral degeneration. They were clear that the Calvinist emphasis on justification by faith alone, absolute predestination and the primacy of the elect did

\footnotetext{
121 Tillotson, 'The Efficacy, Usefulness, and Reasonableness of Divine Faith', 166-67; 'Of the Christian Faith, the Means of Its Conveyance, and Our Obligation to Receive It', 187-88.

${ }_{122}$ McGee, The Godly Man in Stuart England: Anglicans, Puritans, and the Two Tables, 1620-1670, 107-8.
} 
nothing but undermine the social and political order. ${ }^{123}$ Thus, the Restoration clergy's aim was to rebuild morality damaged by the previous 'solifidian' sectaries. $^{124}$

A plea for divine life was a broad agenda. The moderate clergy needed more to say about piety in practice. So example of primitive virtues was taken to suggest the elements or attributes of divine piety. Several virtues were highly recommended by the latitudinarians. Edward Fowler's plea for piety was well expressed in his work Principles and Practices of Certain Moderate Divines of the Church of England in 1670. It is significant that Fowler connected virtues which moderate divines had recommended to those which the primitive Christians had. These moderate divines, Fowler wrote, understood that 'Moral righteousness' meant 'the whole duty of man, to God, his Neighbour, and Himself'. Fowler stressed that Christ himself and apostles taught that moral righteousness implied 'inward rectitude and integrity; and doing all the good we can from the best and most divine principles ... or that divine and heavenly life whose root is faith in God and our Saviour Christ'. Some primitive virtues, humility, purity, and charity were parts of righteousness. ${ }^{125}$

Latitudinarian clergymen stressed the role of the church and clergy in promoting moral development. They, in particular, were concerned with how the Church of England could edify the lay people. Among the effective tools were pastoral works for lay adults, and education for the children. The latitude-men built upon a tradition of pastoral writing. Jeremy Taylor, for instance, wrote a number of works including a manual of prayers, The Golden Grove. Additionally, his treatises, such as Ductor Dubitantium or the Rule of Consicence (1660), Antiquitates Christianae; or the History of the Life and Death of the Holy Jesus (1675) were recognised as Anglican edifying works. He emphasised the role of the Anglican Church in helping and supporting the people to perform practical morality. ${ }^{126}$

In his sermon on the education of children, Tillotson said, that 'the greatest and noblest work in the world, and an effect of the greatest prudence and care, is to rear and build up a Man, and to form and fashion him to piety, and justice, and

\footnotetext{
123 Spellman, The Latitudinarians and the Church of England, 1660-1700, 114.

124 Spurr, The Restoration Church of England, 1646-1689, 284.

125 Fowler, The Principles and Practices of Certain Moderate Divines of the Church of England, 117-18.

126 Stephen Sykes and John E. Booty, eds., The Study of Anglicanism (London: SPCK, 1988), 167.
} 
temperance, and all kind of honest and worthy actions' ${ }^{127}$ His sermon indicated the duty of parents and instructors when they teach children. For Tillotson children needed to be educated in their whole duty to God and men and to perform practices all the days of their lives. What is important, in his argument, is that fruitful and good education should be conducted in accordance with religious practices. The duty of parents and ministers consisted of several particulars. For example, they were recommended to bring children up to 'baptised and admitted as members of Christ's church'; they should be educated 'in a prudent and diligent care to form their lives and manners to religion and virtue'; they should be 'publickly catechised by the ministers'; and they should be 'brought to the bishop in order to be solemnly confirmed' when they would enter into their baptism. ${ }^{128}$ It was true that Tillotson thought the good education consisted not only of teaching the knowledge of God and their religious duties, but also endeavouring to perform virtue in their lives. $\mathrm{He}$ believed that one of roles of religion was to make children desire holy living and live thereby. That is why Tillotson stressed that children must be carefully informed of the core principles of Christianity like there was a life after death and every man would receive eternal reward or punishment from God according to their actions. Without these religious motives, human passion like fear or hope would only be the source of principles of human action. ${ }^{129}$ These moderate Anglicans believed that good education would have impact on human nature and make it progress towards perfection which God intended to men.

These Anglican divines believed that edification was a central task of ministers. They showed their devotion to the pastoral ministry by engaging in a variety of pastoral activities. It was clear that they thought moral encouragement was primarily involved practical divinity. They saw themselves as pastoral educators, moral guides. Patrick, for example, argued that 'our Ministers teach men their Duties' which were expressed in 'Life and Manners, in our bodily actions, which tend to the good of our Neighbours, and the Happiness of the world'. ${ }^{130}$ Henry More was another exponent of the importance of education. More asserted that education could make people to develop a faculty to understand divine life. Divine life, according to

\footnotetext{
127 Tillotson, 'Sermon LI: Of the Education of Children', in Sermons on Several Subjects and Occasions, by the Most Reverend Dr. John Tillotson, Late Archbishop of Canterbury, vol. 4 (London, 1757), 4.

128 Ibid., 7-8.

129 Ibid., 16.

${ }^{130}$ Patrick, A Friendly Debate between a Conformist and a Non-Conformist (London, 1669), 40.
} 
him, could not exist without human rational spirit which could be grown by a variety of education. ${ }^{131}$ Pastoral activities, they believed, were means of promoting morality. Anglican pastoral care was primarily directed to the laity. A variety of their works were circulated within England. The countess of Shaftesbury, wife of the first earl of Shaftesbury, for example, had her reading materials including Patrick's devotional book, Parable of the Pilgrim and a guidebook of the Prayer Book communion, Christian Sacrifice, and Stillingfleet's anti-Catholic treatise, A Discourse Concerning the Idolatry. ${ }^{132}$ Her library represented that devotional books were used in her religious learning. These works exhorted the laity to increase piety and morality and discipline.

Other English thinkers like John Locke, the philosopher whose thought is most often associated with the outlook of the latitudinarians, also believed that men were to be educated into virtue. For Locke, education is essential to lead men to be good and have virtue. His work, Some Thoughts Concerning Education, first published in 1693, talked about men's moral improvement by education. 'Of all the men we meet with', Locke wrote, 'nine parts of ten are what they are, good or evil, useful or not, by their education. Tis that which makes the great difference in mankind'. ${ }^{133}$ But Locke's view of education was different from latitudinarians' approach in the philosophical theory of human understanding. As his famous idea of tabula rasa presented, Locke's educational ideas rejected the doctrine of innate ideas in human mind. The mind could only be filled by experience. While he emphasised civil education for social stability, latitudinarians' educational ideas were driven by religious motives.

If education was one useful tool to train people to be the good, there was another motive for them to pursue a holy life. Tillotson's sermon expounded another way to drive the people to be persuaded to do good things: happiness. God was 'the Supream good and the greatest Happiness to consist in the enjoyment of him'. Tilltoson continued to argue that Holiness

Makes us like to God; and likeness will make us love him; and love will make us happy in the enjoyment of him; and without this it is impossible to

\footnotetext{
131 More, An Explanation of the Grand Mystery of Godliness (London, 1660), 51-5.

132 Spurr, 'Shaftesbury and the Politics of Religion', in Anthony Ashley Cooper, First Earl of Shaftesbury, 1621 1683, ed., John Spurr (Farnham: Ashgate, 2011), 128.

133 John Locke, Some Thoughts Concerning Education (London, 1693), 2.
} 
be happy. ... So that if we be holy, happiness will result from this temper:

and if we be wicked, we are necessarily and unavoidably miserable. ${ }^{134}$

Some historians have examined how the idea of human progress was interwoven with apocalyptic prophecies, or, in particular, apocalyptic images. Ernest Tuveson is the most important example of this approach. He spells out the millenarian belief of the seventeenth-century contemporaries. Above all, he focuses on their hope for the progress of human beings. Looking at some of prominent polemicists, Tuveson surmises that their thought shows the spread and prevalence of the belief in the progressivism of human nature, mind, and knowledge in seventeenth-century intellectual life. The pursuit of human perfection, Tuveson argues, was the one of most important concerns of the seventeenth-century Anglican clergy. He suggests that Henry More regarded salvation as identical with the improvement of human personality: the process of the soul's salvation gradually guaranteed human perfection in all ways. ${ }^{135}$ A perception that human beings could gain salvation was based on the belief that God's grace must propel fallen human beings - his people who were depraved after Adam's fall - towards perfection in nature. He traces the progressive conception of human nature from the sixteenth century writer Joseph Mede, implying that Mede's millennial progressivism might have influenced More. ${ }^{136}$ However, Tuveson thinks that there was another way of understanding human perfection in the seventeenth century. 'The advance of civilization, the gradual increase of man's knowledge and moral refinement', he finds, consist of 'salvation'. Moral improvement, Tuveson argues, is understood as an optimistic view of the human status. In other words, the process of the renovation of human nature into true righteousness is to be achieved through the disposal of corrupt religion as the world progresses in religious knowledge and understanding. In this respect, he implies that the role of Christ cannot help but be reduced to the 'one of the teacher or prophet', not a personal saviour. ${ }^{137}$ This progressivism insinuates that the role of traditional religion is now reduced to the revelation and affirmation of the minimum essentials of faith. At first God's intention was the perfection of human nature and human history could witness this true course of perfectibility. The

\footnotetext{
134 Tillotson, ‘The Efficacy, Usefulness, and Reasonableness of Divine Faith', 153-54.

135 Ernest Lee Tuveson, Millennium and Utopia: A Study in the Background of the Idea of Progress (New York: Harper \& Row, 1964), 99.

136 Ibid., ix.

137 Ibid., 97.
} 
rejection of external practices in religion and the adherence to internal mediation seem to be apparent in More's Christian theology. Tuveson characterizes the religion that More conceived as contrary to 'legalism or a set of magical formulae designed to compensate by eternal means for sin.' In short, Tuveson argues, for More the end of religion was to make men better moral beings. ${ }^{138}$

Henry More's apocalyptic idea thus becomes an exemplar of the modern style at the hearts of convictions about progressive human nature. Tuveson's study of seventeenth-century eschatology rests upon the assumption that the seventeenthcentury English intellectuals broke with the previous ages which are thought to have retained conventional doctrines. For Tuveson, the moderates represent 'rational religion'. Despite all the arguments Tuveson sets forth, it still remains to be considered whether the seventeenth-century elites, like Henry More and his followers, had 'progressivism' in a modern sense in their minds. First of all, it is worth reconsidering how they thought of their 'progressivism'. As he suggests in the introduction, it is significant that belief in progress is much indebted to the millennial tradition. $^{139}$

The need for moral reform or the hope for human progressivism is explained by a variety of causes. Even though in retrospect the latitudinarians' theology seems to be a variation of evolutionism, what they tell us is not all about progressivism. For Anglican churchmen the concern of morality was one of several urgent issues. They thought an urgent campaign against vices was needed and special care should be directed to a series of schemes for moral reform. The terms used in support for moral renewal largely derived from the traditional, not 'modern' idea.

A notion of 'progressivism' was carried into the heart of the seventeenthcentury apocalyptic thought. Looking into More's millennial doctrine, as briefly mentioned above, Tuveson concludes that the seventeenth-century providentialism, gradually but evidently, had changed into human-centred progressivism. ${ }^{140}$ It is true that More, like other latitudinarian colleagues, insisted that the whole function of religion is to make men better and better so that religion, of course, had to have the minimum essentials of belief that even the 'vulgar' can understand them. ${ }^{141}$

\footnotetext{
138 Ibid., 129.

139 Ibid., 1-3.

140 Ibid., 97.

141 Ibid., 99, 114.
} 
However, it is obvious that the latitudinarian vindication of moral reform took root in the conventional conception of Christian soteriology. Their soteriology could be regarded as progressivism in the inevitable fulfilment of providence through temporal history, but it retained many traditional aspects. Although the moderate Anglicans began to accept the new science and the human knowledge increased by it, the fear of God's punishment upon vices was their prime concern.

During these intense controversies between religious groups, it was natural for latitudinarians to link the rhetoric of moral improvement (employed as a weapon against religious adversaries) to their vindication of the Church of England as rational religion. The relationship between reason and Christianity in the seventeenth century has been much studied by early modern historians. Among them, recently, Bulman has portrayed the seventeenth-century intellectual climate in terms of an 'Anglican Enlightenment'. Bulman's study looks at the versatile Anglican intellectual William Addison's thought in a variety of areas including politics, religion, and oriental knowledge and so on. His work not only reveals of the religious thought of the individual but also provides a broad intellectual context in which his thought can be understood. In fact, Addison is described as the moderate who was well educated in humanistic scholarship at Oxford University. The main assumption of Bulman's study is that the civic humanism and classic liberalism from the early seventeenth century consequently led England to the first version of the Enlightenment, or as he puts it, an 'Anglican Enlightenment'. This 'early Enlightenment' emerges from the literature, scholarship, civil and religious strife, and other condition of the seventeenth century, but it was neither inevitable nor inevitably associated with the rejection of religious orthodoxy. ${ }^{142}$ The way that Bulman appreciates seventeenth-century English history tries to avoid so-called 'Whiggish' historiography and scrutinises Anglican churchmen of later Stuart England at various levels. 142 Bulman, Anglican Enlightenment: Orientalism, Religion and Politics in England and Its Empire, 1648-1715,
xiv, 4. 
Bulman successfully demonstrates that the ideas of natural law, civil religion, and the plain style of literature were employed and developed by Anglican clergy and were shared by many contemporaries. Moral reform, for example, is described as one of European efforts in the seventeenth century. Bulman shows that the SPCK and the Society for the Propagation of the Gospel in Foreign Parts (SPG) which were organized during the late seventeenth and early eighteenth centuries were motivated by their Anglican predecessors and the Roman Catholics who had pursued the spread of Catholicism abroad as means of recovering from a losing power in Northern Europe. ${ }^{143}$ The motive for these societies is connected with the perception of religion as a means of civil utility. Catechizing, Bulman explains, was considered to be a useful way to play a significant role in the edification of laity. The catechism, to put it in Addison's words, 'signifies a familiar and easy method of instilling the rudiments of any art, science or faculty'. ${ }^{144}$ For Bulman the Anglican emphasis on the moral function of catechizing is easily understood as a means of maintaining civil peace. The widespread appeal to catechizing in the late seventeenth century, in his view, suggests that the rhetoric of moral reform including a moderate scheme of toleration is not the preserve of 'latitudinarians'. A variety of religious opinions among conformists and Nonconformists is to be said to share a common aim of civil stability. In line with efforts to maintain civil peace, Bulman adds another reason for moral reform. The rising issue of irreligion provoked 'a national effort to promote moral virtue'. ${ }^{145}$

Bulman's interpretation of the seventeenth-century Anglican Enlightenment shows the process of secularization of religious society. This study pictures moral reform as an aspect of rational religion. It is true that the need for moral reform caused a number of societies for 'the reformation of manners' during the postrevolutionary period. The insistence on moral improvement had been raised by English elites from the Restoration. Especially other religious motive for moral reform such as the rational mode of apocalyptic idea which consistently fueled an expectation for eternal felicity for the future was a key to the movement. The mixed rhetoric of civil utility and Christian tradition would have provided a unique intellectual situation in the seventeenth century.

\footnotetext{
143 Ibid., 69-70

144 Ibid., 156.

145 Ibid., 254.
} 
In fact, the latitudinarians, including many Englishmen who emphasised the reasonableness of religious doctrine and practices, were convinced that the edification of human beings could drive out religious impiety. Thus it was not surprising that they emphasised the importance of learning and reading the scriptures with human reason. The latitudinarian support for the use of reason was unequivocal in More's view of the process of the soul's redemption. More thought that the redemptive process is the gradual regaining of the 'divine life', and this process is responsible for the best achievements of intellectual knowledge as well as for moral improvement'. ${ }^{146}$ The latitudinarians thought that moral defect was caused by the lack of endeavour to learn or teach Christian truth. In Patrick's words, 'Superstition grew up on the ruins of Learning'. ${ }^{147}$

While modern minds were confident in the development of natural science and the progress of human knowledge, they, at the same time, readily related the unfinished process of Protestant reformation with apocalyptic themes like the sense of the church in danger and of the imminence of God's punishment. In the face of the decline of religion, the restoration of Christian piety became an urgent task. Indeed, revealed religion remained crucial to seventeenth-century contemporaries in the shape of religion that emphasised its moral function in human society. In particular, when we look at the consistent theme of the providential and apocalyptic worldview, we have to recognize that Anglican warnings of immorality and the subsequent demand for moral reform were still shaped from within the apocalyptic world view of seventeenth-century English Protestantism.

\footnotetext{
146 Tuveson, Millennium and Utopia: A Study in the Background of the Idea of Progress, 129.

147 Patrick, Consolatory Discourse, Perswading to a Chearfull Trust in God in These Times of Trouble and Danger, 33 .
} 


\section{Conclusion}

This thesis has aimed to discover the patterns of apocalyptic belief between 1660 and 1688 that shaped latitudinarians' particular and distinctive views about Restoration religion and politics. As I have shown, apocalyptic ideas remained very much alive in the writings of latitudinarian divines, and held an important, if not crucial, position in religious and political discourse between the latitudinarians and contending parties. The continuous tradition of English apocalyptic thinking formed by John Bale, John Foxe, Thomas Brightman, and Joseph Mede provided a basis for Henry More's apocalyptic worldview. While accepting the whole structure of the apocalyptic tradition, this Cambridge thinker's apocalyptic understanding was far from radical indeed it was used to maintain the existing religious and political culture. Given that the Cambridge Platonists like More had a strong influence on the latitudinarians, it is not surprising that these younger Anglicans' apocalyptic belief was also bound up with the defence of the Church of England and the English monarchy. Many latitudinarians' understanding of providential worldview was grounded in this tradition of thought from the sixteenth century and earlier.

Two main patterns of the apocalyptic tradition were espoused by the sixteenth-century apocalyptic thinkers whose influence was the basis of these Anglicans' apocalyptic thinking. On one hand, they understood, in general, that the whole of human history was guided by God's providential plan, so they agreed that it was necessary to interpret the scriptural prophecies and apply them to current events. On the other hand, they believed that the Reformation was a crucial moment from the apocalyptic perspective, and England would play a key role in the realisation of the apocalyptic and providential drama. These two characteristics of the English apocalyptic tradition motivated the latitudinarians, like other Protestant writers, to see English history as a sacred story following a predestined divine plan to a climax in the new age.

Based on these features, the latitudinarians formed their own views on various issues that arose during the Restoration. In chapter 2 I have shown that the latitudinarian drew upon apocalyptic language to attack the doctrines of the Catholic Church in their discourse of anti-popery, claiming that the apocalyptic term 'Antichrist' signified the popes and the Catholic hierarchy. It was in this context that 
the latitudinarians employed the term to criticise the idolatry and tyranny in Catholicism. In the meantime, their use of the apocalyptic term came to associated with a moderate way of applying traditional concepts to political and religious circumstances after the Restoration. The Restoration saw many rival denominations whose principles and doctrines were not based on the same authority. In England the latitudinarians as clergymen needed to call for religious unity under the Church of England and promulgate the Anglican doctrines to the lay people. The fact that they limited the use of Antichrist to the doctrines and institutions in Roman Catholicism indicates that they valued pastoral care for the Catholic laity. At the same time, religious changes in the later seventeenth-century encouraged the latitudinarian appeal to edification rather than persecution, suggesting that the Catholic lay would possibly gain salvation if they would come back to the Church of England. In the discourse of anti-popery, the latitudinarian use of apocalyptic language in a different context provided a different view on religious adversaries.

Latitudinarians' apocalyptic beliefs also underpinned their attitude to religion and politics in the Restoration. Given that they held the basic tenets of the Church of England, it is corollary that they wrote to justify the lawful authority of the Church of England as the true church and claim its inseparable alliance with the civil ruler. As chapter 3 has demonstrated, one of the main themes of their writings of the history of the Reformation and Anglican separation from the Church of Rome was to reveal that the establishment of the Church of England was led by God's providential intervention. Gilbert Burnet's The History of the Reformation of the Church of England, published in three volumes, 1679, 1681, and 1715, which narrated how the Church of England was set up by Henry VIII's decision to divorce the English church from papal dominion and its religious identity was maintained under the reigns of Tudor and Stuart monarchs, was deeply associated with his apocalyptic belief in the revival of true religion against antichristian tyranny. Burnet's providential historiography did not show a mere recurrence of the apocalyptic tradition. He was not concerned with the detailed exposition of prophetic images and terminology but was willing to combine the apocalyptic worldview with a different set of discourse to provide more reasonable grounds to believe that the separation of the Church of England from the Church of Rome was a genuine reformation of true religion. When Burnet traced an original model of true religion to the primitive 
church, he argued for the restoration of that church's religious virtues which were also advocated by the majority of the latitudinarians. Like Burnet, More, Stillingfleet, and Tillotson adapted the apocalyptic understanding of true religion to religious circumstances. In short, as the full realisation of God's providential plan to restore true religion had not yet come, the latitudinarians felt that if the Henrician Reformation constituted a crucial moment in the history of the Church of England, the reformation of the Church was unfinished and so constant efforts were necessary to follow the path of the primitive Christians by pursuing their religious virtues.

A desire to vindicate of the divine authority of the Church of England was tied in with a defence of king's sacred authority in the latitudinarian view of the relationship between religion and politics. The apocalyptic notion of the godly ruler played a significant role in making the latitudinarian picture of the role of the civil magistrate. As described in chapter 4, they used various biblical images and figures to describe the divine authority of the monarch, claiming that the restoration of the monarchy represented God's providential control of human society. In the latitudinarian writings this discussion of the godly ruler was combined with their allegedly erastian argument that the civil magistrate had right authority to govern religious matters. During the later seventeenth century, their interest in religious unity ran high so these Anglicans emphasised the lawful authority of the monarch to secure true Christian religion from false religion with its dangers of enthusiasm, immorality, and persecution.

More importantly, the term of the 'godly ruler' or king was attached to the controversial principle that civil government had royal supremacy over religion and was jurisdictional as to determine external matters in religion while clergy held pastoral position to preach the teachings of true Protestant church and give advice to the monarch in relation to religious issues. This argument led to their rejection to a premise that the Episcopal Church was founded upon divine right and the church government was left to the civil magistrate's determination. Counterparts saw the latitudinarians as subordinating the church to the king. High-churchmen, Nonconformists, and even Catholics attacked the latitudinarians, accusing them of promoting Hobbian or Erastian principles. This accusation of the latitudinarians has persisted in modern historiography. Jon Parkin and Jacqueline Rose have partly 
maintained the trend to link latitudinarian political thought to Hobbism. ${ }^{1}$

However, the evaluation of the latitudinarians in terms of Erastianism needs to be understood within the context of their call for the legitimate authority of the godly ruler. The discourse to justify the jurisdiction of the civil magistrate in ecclesiastical matters was not only rooted in Erastianism but also was motivated by the apocalyptic sense of the godly ruler who was set up by divine providence to punish heresy and promote true religion. Throughout the Restoration the latitudinarians felt the need for religious unity in the form of the Church of England. In their minds, the royal supremacy over 'indifferent things' could be justified as God elected the godly ruler as guardian of true church and supporter civil and religious unity from antichristian evil.

In the last chapter I have argued that apocalyptic ideas formed the background of the soteriology of Anglican latitudinarians. Basically, the reaction against Calvinist and Catholic teachings about salvation marked Anglican soteriology in the seventeenth century. In response to Calvinist emphasis on grace and predestination on the one hand, and Catholic claim of salvation through the mediation of sacraments established by the priestly hierarchy in the Catholic Church on the other hand, the latitudinarians focused on the necessity of human works in gaining salvation. Such an emphasis was related to a constant call for human efforts to overcome sin and live a morally good life. At the centre of latitudinarians' theology, thus, lay the emphasis on moral reform.

Apocalyptic thinking offered the important advantage for the latitudinarians to promote individual and national moral reform. As the latitudinarian divines saw Restoration England in danger of immorality and impiety, they insisted on the necessity of repentance which was the first step to restore the harmonious relationship between human beings and God. Stillingfleet, Taylor, Patrick, and Tillotson understood religious and political upheavals in the context of divine wrath so the exhortation of repentance and the warning of divine punishment became one of the main themes in their apocalyptic thinking. They believed that England's destiny was under the control of divine providence which would bring the nation to

\footnotetext{
1 Jon Parkin, Taming the Leviathan: The Reception of the Political and Religious Ideas of Thomas Hobbes in England, 1640-1700 (Cambridge: Cambridge University Press, 2007), chaps. 5, 6 and 7; Jacqueline Rose, Godly Kingship in Restoration England: The Politics of the Royal Supremacy, 1660-1688 (Cambridge: Cambridge University Press, 2011), chap. 5.
} 
judgment. They thought that individual vice or piety could have an impact on providential judgment on the nation, arguing that horrific tragedies and natural disasters occurring in the nation was a presage to the coming judgment on immorality and social vices. This apocalyptic understanding fuelled zeal for their reformation of manners as well as morals.

At the same time, this apocalyptic view on moral reform supported their belief in human perfection. The Cambridge Platonists' assertion of possibility of human perfection in this life through human rational efforts influenced the latitudinarian support of progress in human knowledge and morality. With penitence and edification, the latitudinarians thought, Christians would be able to be perfect in terms of moral progress. This thinking was interwoven with the argument that humans could gain knowledge of God and moral teachings of the Scriptures by means of their use of reason within the broad picture of the latitudinarians view on religion.

To relate the latitudinarian divines to the movement for natural religion and rational theology is misleading. It is obvious that these latitudinarian clergy were motivated in seeking an alternative for religious conflicts in the later seventeenth century by apocalyptic motives associated with anti-Catholicism, the hope for religious unity under the godly monarch, and an optimistic view about human nature and moral enhancement. I am not intending to suggest that the latitudinarians were deeply involved in the exposition of the apocalypse. In fact, they took no particular interest in the calculation of apocalyptic chronologies and the detailed interpretation of images in the biblical prophecies. The latitudinarians' approach was not apocalyptic in a traditional sense. What their apocalyptic belief drew on more were key principles that underlay apocalyptic ideas rather than on the synchronisation of prophetic texts and the identification of specific images. In other words, the latitudinarians' apocalyptic belief was identical with the search for the providential design of human society.

Therefore, the latitudinarian application of apocalyptic interpretation to later seventeenth-century circumstances represents the continuities between the Reformation and the Restoration in terms of the use of apocalyptic narratives. This implies that some religious traditions still remained strong enough to shape moderate Anglicans' worldview. In this context, Restoration England marked a crucial 
moment when the complicated symbiosis of traditional and modern notions. 


\section{Bibliography}

\section{Primary Sources}

Anonymous, The Expedition of His Highness the Prince of Orange for England (London, 1688).

- A Full Account of the Barbarous and Unhumane Usages of the French Protestants in France (n.p., 1685).

Atterbury, Francis, A Letter to a Convocation Man Concerning the Rights, Powers, and Priviledges of That Body (London, 1697).

Bale, John, 'The Image of Both Churches', in Select Works of John Bale, D.D., Bishop of Ossory: Containing the Examinations of Lord Cobham, William Thorpe, and Anne Askewe, and the Image of Both Churches, ed., Henry Christmas (Cambridge, 1849).

Baxter, Richard, The Cure of Church-Divisions (London, 1670).

—, A Paraphrase on the New Testament, with Notes, Doctrinal and Practical (London, 1685).

Brightman, Thomas, A Revelation of the Revelation (Amsterdam, 1615).

Burnet, Gilbert, Bishop Burnet's History of His Own Time, 3 vols. (London, 1725edition).

— Essay on the Memory on the Memory of the Late Queen (London, 1695).

—, An Exposition of the Thirty-Nine Articles of the Church of England (London, 1700).

- The History of the Reformation of the Church of England, 3 vols. (London, 1679-1715).

—, A Letter Written Upon the Discovery of the Late Plot (London, 1678).

- The Mystery of Iniquity Unveiled in a Discourse, Wherein Is Held Forth the Opposition of the Doctrine, Worship, and Practices of the Roman Church (London, 1673).

—, A Relation of the Death of the Primitive Persecuters (Amsterdam, 1687).

- Rome's Glory and the Mystery of Iniquity (London, 1673). 
-, A Sermon Preached at the Chappel of the Rolls, on the Fifth of November, 1684. Being Gun-Powder-Treason-Day (London, 1684).

—, A Sermon Preached at the Funeral of the Most Reverend Father in God, John Tillotson (London, 1709).

—, A Sermon Preached before the House of Commons, on the 31th of January, 1688. Being the Thanks Giving-Day for the Deliverance of This Kingdom from Popery and Arbitrary Power, by His Highness the Prince of Orange's Means (London, 1689).

—, A Sermon Preached before the Right-Honourable the Lord-Mayor and Aldermen of the City of London, at Bow-Church, September 2, 1680. Being the Anniversary Fast for the Burning of London (London, 1680).

—, A Sermon Preached in the Chappel of St. James's, before His Highness the Prince of Orange, the 23d of December, 1688 (London, 1689).

—, The Unreasonableness and Impiety of Popery (London, 1678).

- - A Vindication of Ordinations of the Chruch of England (London, 1677).

- The Vindication of the Authority, Constitution, and Laws of the Church and State of Scotland (Glasgow, 1673).

Calvin, Jean, Commentaries on the Book of the Prophet Daniel, ed., Thomas Myers (Grand Rapids, 2007).

- Commentaries on the Catholic Epistles, ed., John Owen (Grand Rapids, 2007).

- Commentaries on the Epistles to Timothy, Titus, and Philemon, ed., William Pringle (Grand Rapids, 2007).

- Commentary on the Book of the Prophet Isaiah, ed., William Pringle (Grand Rapids, 2007).

—, Institutes of the Christian Religion, trans., Henry Beveridge, 2 vols. (Edinburgh, 1863).

Challoner, Richard, A Short History of the First Beginning and Progress of the Protestant Religion, Gathered out of the Best Protestant Writers, 12th ed. (London, 1795).

Constable, John, Deism and Christianity Fairly Consider'd, in Four Dialogues (London, 1739). 
[Cooper, Anthony Ashley], A Letter from a Person of the Quality to His Friend in the Country (London, 1675).

Cressy, Hugh, Exomologesis: Or a Faithfull Narration of the Occasion and Motives of the Conversion Unto Catholic Unity (Paris, 1653).

Cudworth, Ralph, A Sermon Preached to the Honourable Society of Lincolnes-Inne (London, 1664).

Dodd, Charles, The Church History of England from the Year 1500 to the Year 1688, 3 vols. (Brussels, 1739-1742).

Evelyn, John, Diary and Correspondence of John Evelyn, F. R. S. To Which Is Subjoined the Private Correspondence between King Charles I and Sir Edward Nicholas and between Sir Edward Hyde, Afterwards Earl of Clarendon, and Sir Richard Browne, ed., William Bray (London, n.d.).

Fowler, Edward, The Principles and Practices of Certain Moderate Divines of the Church of England (London, 1670).

- A Sermon Preached at the General Meeting of Gloucestershire-Men; for the Most Part Inhabitants of the City of London: In the Church of St. Mary LeBow, December the 9th 1684 (London, 1685).

Foxe, John, The Acts and Monuments (London, 1563).

Glanvill, Joseph, 'Sermon III: Christian Loyalty, Preach'd on the King's Martyrdome', in Some Discourses, Sermons and Remains (London, 1681).

Godden, Thomas, Catholicks No Idolaters: Or a Full Refutation of Dr. Stillingfleet's Unjust Charge of Idolatry against the Church of Rome (London, 1672).

—, A Just Discharge of Doctor Stillingfleet's Unjust Charge of Idolatry (Paris, 1677).

Goodwin, Thomas, The Works of Thomas Goodwin, ed., John Miller, 10 vols. (Edinburgh, 1861-1865).

Hammond, Henry, Charis Kai Eirēenē, or, a Pacifick Discourse of Gods Grace and Decrees (London, 1660).

- Practical Catechisme (London, 1646).

Heylyn, Peter, Cyprianus Anglicanus: Or the History of the Life and Death of the Most Reverend and Renowned Prelate William (London, 1668).

- Ecclesia Restaurata; or the History of the Reformation of the Church of England (London, 1661). 
Heywood, Oliver, The Whole Works of the Rev. Oliver Heywood, Now First Collected, Revised, and Arranged, ed., John Vint, 5vols. (Edinburgh, 18251827).

Hickes, George, An Apology for the New Separation (London, 1691).

Hume, David, Essays and Treatises on Several Subjects, 2nd ed., 4 vols. (London, 1753).

Hyde, Edward, 'Contemplations and Reflections Upon the Psalms of David', in $A$ Collection of Several Tracts of the Right Honourable Earl of Clarendon (London, 1727).

Jurieu, Pierre, Monsieur Jurieu's Pastoral Letters, Directed to the Protestants in France, Who Groan under the Babylonish Captivity (London, 1688).

Kippis, Andrew, and Joseph Towers, eds., Biographia Britannica, or the Lives of the Most Eminent Persons Who Have Flourished in Great-Britain and Ireland, 2nd ed., 5 vols. (London, 1778-1793).

Lloyd, William, A Seasonable Discourse Shewing the Necessity of Maintaining the Established Religion in Opposition to Popery (London, 1673).

Locke, John, Some Thoughts Concerning Education (London, 1693).

Lowth, Simon, Of the Subjects of Church Power (London, 1685).

Luther, Martin, Luther's Works, Vol. 35, Word and Sacrament I, ed., E. Theodore Bachmann, 55 vols. (Philadelphia, 1960).

[Marvell, Andrew], An Account of the Growth of Popery, and Arbitrary Government in England (Amsterdam, 1677).

Mede, Joseph, The Key of the Revelation (London, 1643).

—, The Works of the Pious and Profoundly Learned Joseph Mede, ed., John Worthington (London, 1664).

More, Henry, Apocalypsis Apocalypseos; or the Revelation of St John the Divine Unveiled (London, 1680).

—, An Explanation of the Grand Mystery of Godliness (London, 1660).

- An Exposition of the Seven Epistles to the Seven Churches Together with a Brief Discourse of Idolatry (London, 1669).

—_, An Illustration of Those Who Abstruse Books in Holy Scripture (London, 1685).

— 
_- Paralipomena Prophetica: Containing Several Supplemenss and Defences of Dr H. More (London, 1685).

—., A Plain and Continued Expeosition of the Several Prophecies (London, 1681).

— Some Cursory Reflections Impartially Made Upon Mr. Richard Baxter His Way of Writing Notes on the Apocalypse, and Upon His Advertisement and Postcript (London, 1685).

- Synopsis Prophetica; or, the Second Part of the Enquiry into the Mystery of Iniquity (London, 1664).

Nelson, Abraham, A Perfect Description of Antichrist (London, 1660).

Nicols, Daniel, A Sermon Preach'd in the Cathedral of Lincoln, July XVIII, 1681 (London, 1681).

Patrick, Simon, Anglicae Speculum: A Glass That Flatter Not, Presented to a Country Congregation at the Late Solemn Fast, April 24, 1678 (London, 1678).

—, An Answer to a Book, Spread Abroad by the Romish Priests, Intituled, the Touchstone of the Reformed Gospel Wherein the True Doctrine of the Church of England and Many Texts of the Holy Scripture Are Faithfully Explained (London, 1692).

- Consolatory Discourse, Perswading to a Chearfull Trust in God in These Times of Trouble and Danger (London, 1665).

—, A Continuation of the Friendly Debate by the Same Author (London, 1669).

—, A Friendly Debate between a Conformist and a Non-Conformist (London, 1669).

—, A Friendly Debate Betwixt Two Neighbours (n.p., 1668).

- Mensa Mystica; or a Discourse Concerning the Sacrament of the Lords Supper (London, 1660).

- The Parable of the Pilgrim (London, 1665).

—, A Private Prayer to Be Used in Difficult Times (London, 1687).

- , A Sermon Preached at St. Paul's Covent-Garden on the First Sunday in Lent (London, 1689).

- A Sermon Preached in the Chappel of St. James's before His Highness the Prince of Orange, the 20th of January, 1688 (London, 1689). 
- A Treatise of Repentance and of Fasting, Especially of the Lent-Fast (London, 1686).

Pepys, Samuel, The Diary of Samuel Pepys, eds., Robert Latham and William Matthews, 11 vols. (London, 1976).

Pope, Alexander, An Essay on Man (Dublin, 1745).

Sander, Nicholas, Rise and Growth of the Anglican Schism Published A. D. 1585, trans., David Lewis (London, 1877).

Sergeant, John, A Letter to the D. Of P. In Answer to the Arguing Part of His First Letter to Mr. G (London, 1687).

—, Reason against Raillery: Or, a Full Answer to Dr. Tillotson's Preface against J. S. With a Farther Examination of His Grounds of Religion (n.p., 1672).

— Sure-Footing in Christianity, or Rational Discourses on the Rule of Faith (London, 1665).

Sharp, John, 'Sermon II, Preached before the Lords Spiritual and Temporal in Parliament Assembled, in the Abbey-Church at Westminster, on the 30th of January 1699/1700', in Sermons Preached on Several Occasions: With Two Discourses of Conscience, vol. 2 (London, 1715).

-, 'Sermon IV, Preached at the Coronation of Queen Anne; in the AbbeyChurch at Westminster, on the 23d of April, 1702', in Sermons Preached on Several Occasions: With Two Discourses of Conscience, vol. 2 (London, 1715).

- A Sermon Preached at White-Hall in Lent on Friday March 20, 1684/5 (London, 1685).

- A Sermon Preached on the Day of the Public Fast, April the 11th. 1679 (London, 1679).

—, 'Sermon X, Preached before the Lords Spiritual and Temporal in the AbbeyChurch at Westminster, on the 5th of November, 1691', in Fifteen Sermons Preached on Several Occasions, 5th ed. (London, 1722).

Smith, John, Select Discourses, 2nd ed. (London, 1673).

Stillingfleet, Edward, A Discourse Concerning the Idolatry Practised in the Church of Rome (London, 1671).

— A Discourse Concerning the Nature and Grounds of the Certainity of Faith, in Answer to J. S. His Catholick Letters (London, 1688). 
—, Irenicum. A Weapon-Salve for the Churches Wounds, or the Divine Right of Particular Forms of Church-Government (London, 1660).

- Origines Britannicae, or, the Antiquities of the British Churches with a Preface Concerning Some Pretended Antiquities Relating to Britain, in Vindication of the Bishop of St. Asaph (London, 1685).

- A Rational Account of the Grounds of Protestant Religion Being a Vindication of the Lord Archbishop of Canterbury's Relation of a Conference (London, 1665).

- The Reformation Justified: In a Sermon Preached at Guild-Hall Chappel Septemb. 21. 1673 before the Lord Major and Alderman (London, 1674).

- 'Scripture and Tradition Compared in a Sermon Preached at Guild-HallChapel, Novemb 27, 1687', in Fifty Sermons Preached Upon Several Occasions (London, 1707).

, A Second Discourse in Vindication of the Protestant Grounds of Faith, against the Pretence of Infallibility in the Roman Church (London, 1673).

—, A Sermon Preached before the King January 30, 1669 (London, 1669).

—, A Sermon Preached on the Fast-Day November 13, 1678 at St. Margarets Westminster before the Honourable House of Commons (London, 1679).

—, 'Sermon XIV, Preached Novemb. 5. 1673. At St. Margaret's Westminster before the Honourable House of Commons', in Fifty Sermons Preached Upon Several Occasions (London, 1707).

— 'Sermon XVI, Preached on the Fast-Day at St. Margaret's Westminster, November 13. 1678', in Fifty Sermons Preached Upon Several Occasions (London, 1707).

- 'Sermon XX: Of the Nature of Superstition Preached at St. Dunstans West March 31, 1682 ', in Fifty Sermons Preached on Several Occasions (London, 1707).

- Several Conferences between a Romish Priest, a Fanatick Chaplain, and a Divine of the Church of England (London, 1679).

Taylor, Jeremy, 'An Exhortation to the Imitation of the Life of Christ', in Antiquitates Christianae or the History of the Life and Death of the Holy Jesus, 7th ed. (London, 1684). 
, Holy Living in Which Are Described the Means and Instruments of Obtaining Every Virtue, and the Remedies against Every Vice, and Considerations Serving to the Resisting All Temptations, 5th ed. (London, 1656).

Tillotson, John, 'The Efficacy, Usefulness, and Reasonableness of Divine Faith', in Fifteen Sermons on Various Subjects, ed., Ralph Barker (London, 1703).

—, The Hazard of Being Saved in the Church of Rome (London, 1673).

- 'The Necessity of Repentance and Faith', in Several Discourses of Repentance, ed., Ralph Barker (London, 1700).

—, 'Of the Christian Faith, the Means of Its Conveyance, and Our Obligation to Receive It', in Fifteen Sermons on Various Subjects, ed., Ralph Barker (London, 1703).

- The Protestant Religion Vindicated from the Charge of Singularity \& Novelty in a Sermon Preached before the King at White-Hall April the 2d, 1680 (London, 1680).

- The Rule of Faith \& an Answer to the Treatise of Mr. I. S. Entitled, SureFooting (London, 1666).

- The Rule of Faith or an Answer to the Treatise of Mr. I. S. Entituled, SureFooting, \&C, 2nd ed. (London, 1676).

- 'Sermon CXXXIV: The Evidence of Our Saviour's Resurrection', in The Works of the Reverend Dr. John Tillotson, 6th ed., 12 vols. (Dublin, 1739).

— ' 'Sermon L: Christianity Doth Not Destroy, but Perfect the Law of Moses', in The Works of the Most Reverend Dr. John Tillotson, Late Archbishop of Canterbury, 2nd ed., 3 vols. (London, 1717).

- 'Sermon LIX: Of Constancy in the Profession of the True Religion', in Sermons on Several Subjects and Occasions, by the Most Reverend Dr. John Tillotson, Late Archbishop of Canterbury, 12 vols. (London, 1757).

- 'Sermon LX: Of Constancy in the Profession of the True Religion', in Sermons on Several Subjects and Occasions, by the Most Reverend Dr. John Tillotson, Late Archbishop of Canterbury, 12 vols. (London, 1757).

— , 'Sermon LXVII: The Danger of Apostasy from the True Religion', in The Works of the Reverend Dr. John Tillotson, 6th ed., 12 vols. (Dublin, 1739). 
-, 'Sermon LXXIX: The Blessedness of Good Men after Death', in Sermons on Several Subjects and Occasions, by the Most Reverend Dr. John Tillotson, Late Archbishop of Canterbury, 12 vols. (London, 1757).

—_, 'Sermon LXXXVII: Honesty the Best Preservative against Dangerous Mistakes in Religion', in Sermons on Several Subjects and Occasions, by the Most Reverend Dr. John Tillotson, Late Archbishop of Canterbury, 12 vols. (London, 1757).

—, 'Sermon LXXXVIII: Honesty the Best Perservative against Dangerous Mistakes in Religion', in Sermons on Several Subjects and Occasions, by the Most Reverend Dr. John Tillotson, Late Archbishop of Canterbury, 12 vols. (London, 1757).

—, A Sermon Preached before the Honourable House of Commons, Novemb 5, 1678 (London, 1678).

, 'A Sermon Preached before the King June 30th 1667', in Sermons Preach'd Upon Several Occasions, 3rd ed. 2 vols. (London, 1678).

—, A Sermon Preached November 5, 1678 at St. Margarets Westminster, before the Honourable House of Commons (London, 1678).

, 'Sermon XIII: The Nature of Benefit of Consideration', in Sermons on Several Subjects and Occasions, by the Most Reverend Dr. John Tillotson, Late Archbishop of Canterbury, 12 vols. (London, 1757).

—, 'Sermon XLI: A Thanksgiving-Sermon for the Late Victory at Sea. Preached before the Queen at Whitehall, March the 20th, 1692', in Sermons on Several Subjects and Occasions, by the Most Reverend Dr. John Tillotson, Late Archbishop of Canterbury, 12 vols. (London, 1757).

, 'Sermon XV: The Duty and Reason of Praying for Governours Preached on the 29 of May, 1693', in Sixteen Sermons Preached on Several Subjects and Occasions, ed. Ralph Barker, 2nd ed., 2 vols. (London, 1700).

—, 'Sermon XV: The Necessity of Supernatural Grace, in Order to a Christian Life', in Several Discourses of the Life, Suffering, Resurrection, and Ascension of Christ, ed. Ralph Barker (London, 1701).

— ' 'Sermon XXVI: The Blessedness of Good Men, after Death', in The Works of the Most Reverend Dr. John Tillotson, 6th ed., 12 vols. (Dublin, 1739). 
— , 'Sermon XXVII: The Protestant Religion Vindicated from the Charge of Singularity and Novelty, Preached before the King at Whitehall, April 2 1680', in Sermons on Several Subjects and Occasions, by the Most Reverend Dr. John Tillotson, Late Archbishop of Canterbury, 12 vols. (London, 1757).

— , 'Sermon XXXVII: The Way to Prevent the Ruin of a Sinful People, a FastSermon Preached before the Lord-Mayor', in Sermons on Several Subjects and Occasions, 12 vols. (London, 1757).

-, 'The Wisdom of God, in His Providence Preached at Kensington', in Several Discourses Upon the Attributes of God, ed., Ralph Barker (London, 1699).

— 'Sermon LI: Of the Education of Children', in Sermons on Several Subjects and Occasions, by the Most Reverend Dr. John Tillotson, Late Archbishop of Canterbury, 12 vols. (London, 1757).

Ussher, James, The Reduction of Episcopacy into the Form of Synodical Government (London, 1656).

Warly, John, The Reasoning Apostate: Or Modern Latitude-Man Consider'd, as He Opposeth the Authority of the King and Church (London, 1677).

Whichcote, Benjamin, The Works of the Learned Benjamin Whichcote, 4 vols. (Aberdeen, 1751).

Williams, Griffith, The Great Antichrist Revealed, before This Time, Never Discovered (London, 1660).

\section{Secondary Sources}

Almond, Philip C., 'Henry More and the Apocalypse', Journal of the History of Ideas 54, no. 2 (1993): 189-200.

Atherton, Ian, 'Cathedrals and the British Revolution', in The Experience of Revolution in Stuart Britain and Ireland, eds., Michael J. Braddick and David L. Smith (Cambridge, 2011), 96-116.

Barkun, Michael, ed., Millennialism and Violence (London, 1996). 
Berg, Johannes van den, Religious Currents and Cross-Currents: Essays on Early Modern Protestantism and the Protestant Enlightenment (Leiden, 1999).

Black, Jeremy, 'Confessional State or Elect Nation?: Religion and Identity in Eighteenth-Century England', in Protestantism and National Identity: Britain and Ireland, c.1650-c.1850, eds., Tony Claydon and Ian McBride (Cambridge, 1998), 53-74.

Brückmann, Patricia C., 'Hugh Paulinus Cressy [Name in Religion Serenus]', in Oxford Dictionary of National Biography (2004).

Bulman, William J., Anglican Enlightenment: Orientalism, Religion and Politics in England and Its Empire, 1648-1715 (Cambridge, 2015).

_- 'Enlightenment and Religious Politics in Restoration England', History Compass 10, no. 10 (2012): 752-64.

Burns, William, An Age of Wonders (Manchester, 2002).

Capp, Bernard S., The Fifth Monarchy Men: A Study in Seventeenth-Century English Millenarianism (London, 1972).

Carroll, Robert Todd, The Common-Sense Philosophy of Religion of Bishop Edward Stillingfleet, 1635-1699 (The Hague, 1975).

Chamberlain, Jeffrey S., 'The Limits of Moderation in a Latitudinarian Parson: Or, High-Church Zeal in a Low Churchmen Discover'd', in The Margins of Orthodoxy: Heterodox Writing and Cultural Response, 1660-1750, ed., Roger D. Lund (Cambridge, 1995), 195-215.

Champion, J. A. I., The Pillars of Priestcraft Shaken: The Church of England and Its Enemies, 1660-1730 (Cambridge, 1992).

Christianson, Paul, 'From Expectation to Militance: Reformers and Babylon in the First Two Years of the Long Parliament', The Journal of Ecclesiastical History 24, no. 3 (1973): 225-44.

- Reformers and Babylon: English Apocalyptic Visions from the Reformation to the Eve of the Civil War (Toronto, 1978).

Clark, J. C. D., 'Providence, Predestination and Progress: Or, Did the Enlightenment Fail?', Albion: A Quarterly Journal Concerned with British Studies 35, no. 4 (2003): 559-89.

Clarke, T. E. S., and H. C. Foxcroft, eds., A Life of Gilbert Burnet, Bishop of Salisbury (Cambridge, 1907). 
Claydon, Tony, 'Latitudinarianism and Apocalyptic History in the Worldview of Gilbert Burnet, 1643-1715', The Historical Journal 51, no. 3 (2008): 577-97.

_ William III and the Godly Revolution (Cambridge, 1996).

Coffey, John, John Godwin and the Puritan Revolution: Religion and Intellectual Change in Seventeenth Century England (London, 2006).

- ed., Persecution and Toleration in Protestant England, 1558-1689 (Harlow, 2000).

Coffey, John, and Paul Chang-Ha Lim, eds., The Cambridge Companion to Puritanism (Cambridge, 2008).

Collins, Jeffrey R., 'The Restoration Bishops and the Royal Supremacy', Church History 68, no. 3 (1999): 549-80.

Condren, Conal, The Language of Politics in Seventeenth-Century England (Basingstoke, 1994).

Cope, Jackson I., "The Cupri-Cosmits": Glanvill on Latitudinarian AntiEnthusiasm', Huntington Library Quarterly 17, no. 3 (1954): 269-86.

Cornwall, Robert D., 'The Search for the Primitive Church: The Use of Early Church Fathers in the High Church Anglican Tradition, 1680-1745', Anglican and Episcopal History 59, no. 3 (1990): 303-29.

—, Visible and Apostolic: The Constitution of the Church in High Church Anglican and Non-Juror Thought (London, 1993).

Coudert, Allison P., 'Henry More, the Kabbalah, and the Quakers', in Philosophy, Science and Rreligion in England 1640-1700, eds., Richard Kroll, Richard Ashcraft and Perez Zagorin (Cambridge, 1992), 31-67.

Coward, Harold G., The Perfectibility of Human Nature in Eastern and Western Thought (Albany, 2008).

Cragg, Gerald R., From Puritanism to the Age of Reason: A Study of Changes in Religious Thought within the Church of England, 1660 to 1700 (Cambridge, 1950).

Crocker, Robert, 'Henry More and the Restoration', Parergon: Australian and New Zealand Association for Medieval and Early Modern Studies 21, no. 2 (2004): 127-51.

Cummins, Juliet, Milton and the Ends of Time (Cambridge, 2003). 
De Krey, Gary S., 'Reformation and “Arbitrary Government”: London Dissenters and James II's Polity of Toleration, 1687-88', in Fear, Exclusion and Revolution: Roger Morrice and Britain in the 1680s, ed., Jason McElligott (Aldershot, 2006), 13-31.

Dickens, A. G., and John Tonkin, eds., The Reformation in Historical Thought (Oxford, 1985).

Drabble, J. E., 'Gilbert Burnet and the History of the Einglish Reformation: The Historian and His Milieu', Journal of Religious History 12, no. 4 (1983): 35163.

Duffy, Eamon, 'Primitive Christianity Revived: Religious Renewal in Augustan England', Studies in Church History 14 (1977): 287-300.

Fesko, J. V., Beyond Calvin: Union with Christ and Justification in Early Modern Reformed Theology 1517-1700 (Göttingen, 2012).

Firth, Katharine R., The Apocalyptic Tradition in Reformation Britain, 1530-1645 (Oxford, 1979).

Force, James E., and Richard H. Popkin, eds., Millenarianism and Messianism in Early Modern European Culture, Vol. 3, the Millenarian Turn: Science, Politics, and Everyday Anglo-American Life in the Seventeenth and Eighteenth Centuries (Dordrecht 2001).

Gascoigne, J., 'Politics, Patronage and Newtonianism: The Cambridge Example', Historical Journal 27, no. 1 (1984): 1-24.

Geach, Peter, Providence and Evil: The Stanton Lectures, 1971-2 (Cambridge, 1977).

George, Edward Augustus, The Seventeenth Century Men of Latitude: Forerunners of the New Theology (New York, 1908).

Goldie, Mark, 'Danby, the Bishops and the Whigs', in The Politics of Religion in Restoration England, eds., Tim Harris, Paul Seaward and Mark Goldie (Oxford, 1990), 75-105.

—, 'John Locke, Jonas Proast and Religious Toleration 1688-1692', in The Church of England, c.1689-c.1833: From Toleration to Tractarianism, eds., John Walsh, Colin Haydon and Stephen Taylor (Cambridge, 1993), 143-71.

, 'Toleration and the Godly Prince in Restoration England', in Liberty, Authority, Formality: Political Ideas and Culture, 1600-1900, eds., John Morrow and Jonathan Scott (Exeter, 2008), 45-65. 
Graves, Michael A. R., Early Tudor Parliaments, 1485-1558 (London, 1990).

Greig, Martin, 'Gilbert Burnet (1643-1715)', in Oxford Dictionary of National Biography. (2004).

- ' 'Heresy Hunt: Gilbert Burnet and the Convocation Controversy of 1701', Historical Journal 37, no. 3 (1994): 569-92.

Guy, John, 'The Henrician Age', in The Varieties of British Political Thought, 15001800, ed., J. G. A. Pocock (Cambridge, 1993), 13-46.

Haigh, Christopher, 'The Church of England, the Nonconformists and Reason: Another Restoration Controversy', The Journal of Ecclesiastical History 69, no. 3 (2018): 531-56.

Hampton, Stephen, Anti-Arminians: The Anglican Reformed Tradition from Charles II to George I (Oxford, 2008).

Harrison, Peter, The Fall of Man and the Foundations of Science (Cambridge, 2007).

—, "Religion" and the Religions in the English Enlightenment (Cambridge, 1990).

Hayton, David, 'Moral Reform and Country Politics in the Late Seventeenth-Century House of Commons', Past and Present 128 (1990): 48-91.

Hill, Christopher, Antichrist in Seventeenth-Century England (London, 1971).

Hunt, Stephen, Christian Millenarianism: From the Early Church to Waco (London, 2001).

Hutton, Sarah, 'The Appropriation of Joseph Mede: Millenarianism in the 1640s', in Millenarianism and Messianism in Early Modern European Culture, Vol. 3, the Millenarian Turn: Millenarian Contexts of Science, Politics, and Everyday Anglo-American Life in the Seventeenth and Eighteenth Centuries, eds., James E. Force and Richard H. Popkin (Dordrecht 2001), 1-13.

, 'More, Newton, and the Language of Biblical Prophecy', in The Books of Nature and Scripture: Recent Essays on Natural Philosophy, Theology, and Biblical Criticism in the Netherlands of Spinoza's Time and the British Isles of Newton's Time, eds., James E. Force and Richard H. Popkin (Dordrecht, 1994), 39-53.

Hutton, Sarah, and Robert Crocker, eds., Henry More (1614-1687): Tercentenary Studies (Dordrecht, 1990). 
Iliffe, Rob, "Making a Shew": Apocalyptic Hermeneutics and the Sociology of Christian Idolatry in the Work of Isaac Newton and Henry More', in The Books of Nature and Scripture: Recent Essays on Natural Philosophy, Theology, and Biblical Criticism in the Netherlands of Spinoza's Time and the British Isles of Newton's Time, eds., James E. Force and Richard H. Popkin (Dordrecht, 1994), 54-88.

Ingram, Robert G., Religion, Reform and Modernity in the Eighteenth Century: Thomas Secker and the Church of England (Woodbridge, 2007).

Israel, Jonathan I., Radical Enlightenment: Philosophy and the Making of Modernity, 1650-1750 (Oxford, 2001).

Jacob, M. C., and W. A. Lockwood, 'Political Millenarianism and Burnet's Sacred Theory', Science Studies 2, no. 3 (1972): 265-79.

Jacob, Margaret C., 'Millenarianism and Science in the Late Seventeenth Century', Journal of the History of Ideas 37, no. 2 (1976): 335-41.

James, F. G., 'The Bishops in Politics, 1688-1714', in Conflict in Stuart England, eds., William Appleton Aiken and Basil Duke Henning (Hamden, Conn., 1970), 227-57.

Johnston, Warren, 'The Anglican Apocalypse in Restoration England', The Journal of Ecclesiastical History 55, no. 3 (2004): 467-501.

—, 'Revelation and the Revolution of 1688-1689', The Historical Journal 48, no. 2 (2005): 351-89.

- Revelation Restored: The Apocalypse in Later Seventeenth-Century England (Woodbridge, 2011).

Jue, Jeffrey K., Heaven Upon Earth: Joseph Mede (1586-1638) and the Legacy of Millenarianism (Dordrecht, 2006).

Keay, Anna, The Magnificent Monarch: Charles II and the Ceremonies of Power (London, 2008).

Keeble, N. H., The Restoration: England in the 1660s (Oxford, 2002).

King, John N., Foxe's Book of Martyrs and Early Modern Print Culture (Cambridge, 2011).

—. 'John Bale (1495-1563)', in Oxford Dictionary of National Biography (2004).

Kirby, W. J. T., Richard Hooker's Doctrine of the Royal Supremacy (Leiden, 1990). 
Korshin, Paul J., 'Queuing and Waiting: The Apocalypse in England, 1660-1715', in The Apocalypse in English Renaissance Thought and Literature: Patterns, Antecedents, and Repercussions, eds., Constantinos Apostolos Patrides and Joseph Anthony Wittreich (Ithaca, N.Y, 1984), 240-65.

Lacey, Andrew, ed., The Cult of King Charles the Martyr (Woodbridge, 2003).

—, 'The Office for King Charles the Martyr in the Book of Common Prayer, 1662-1685', The Journal of Ecclesiastical History 53, no. 3 (2002): 510-26.

Lake, Peter, 'Anti-Popery: The Structure of a Prejudice', in Conflict in Early Stuart England: Studies in Religion and Politics 1603-1642, eds., Richard Cust and Ann Hughes (London, 1989), 72-106.

, 'Anti-Puritanism: The Structure of a Prejudice', in Religious Politics in Post-Reformation England: Essays in Honour of Nicholas Tyacke, eds., Kenneth Fincham and Peter Lake (Woodbridge, 2006), 80-97.

— , 'The Significance of the Elizabethan Identification of the Pope as Antichrist', The Journal of Ecclesiastical History 31, no. 2 (2011): 161-78.

—, 'William Bradshaw, Antichrist and the Community of the Godly', The Journal of Ecclesiastical History 36, no. 4 (1985): 570-89.

Lamont, William M., Godly Rule: Politics and Religion 1603-60 (London, 1969).

— Richard Baxter and the Millennium: Protestant Imperialism and the English Revolution (London, 1979).

Levy, F. J., Tudor Historical Thought (San Marino, 1967).

Liu, Dai, Discord in Zion: The Puritan Divines and the Puritan Revolution, 16401660 (The Hague, 1973).

Manning, David, 'Anti-Providentialism as Blasphemy in Late Stuart England: A Case Study of "the Stage Debate", Journal of Religious History 32, no. 4 (2008): 422-38.

—, "That Is Best, Which Was First": Christian Primitivism and the Reformation Church of England, 1548-1722', Reformation \& Renaissance Review 13, no. 2 (2011): 153-93.

Marshall, John, 'The Ecclesiology of the Latitude-Men 1660-1689: Stillingfleet, Tillotson and "Hobbism", The Journal of Ecclesiastical History 36, no. 3 (1985): 407-27.

Marshall, Peter, Religious Identities in Henry VIII's England (Aldershot, 2006). 
Martin, Jessica, 'Early Modern English Piety', in The Oxford History of Anglicanism, Vol. 1, Reformation and Identity, c.1520-1662, ed., Anthony Milton (Oxford, 2017), 395-411.

McAdoo, Henry R., The Structure of Caroline Moral Theology (London, 1949).

McGee, J. Sears, The Godly Man in Stuart England: Anglicans, Puritans, and the Two Tables, 1620-1670 (New Haven, 1976).

McGinn, Bernard, 'Angel Pope and Papal Antichrist', Church History 47, no. 2 (2009): 155-73.

- Visions of the End: Apocalyptic Traditions in the Middle Ages (New York, 1998).

McMullan, Gordon, and David Matthews, eds., Reading the Medieval in Early Modern England (Cambridge, 2009).

Miller, John, Popery and Politics in England, 1660-1688 (London, 1973).

Milton, Anthony, Catholic and Reformed: The Roman and Protestant Churches in English Protestant Thought, 1600-1640 (Cambridge, 1995).

—, Laudian and Royalist Polemic in Seventeenth-Century England: The Career and Writings of Peter Heylyn (Manchester, 2007).

Mintz, Samuel I., The Hunting of Leviathan: Seventeenth-Century Reactions to the Materialism and Moral Philosophy of Thomas Hobbes (Cambridge, 1962).

Monta, Susannah Brietz, Martyrdom and Literature in Early Modern England (Cambridge, 2009).

Mortimer, Sarah, Reason and Religion in the English Revolution the Challenge of Socinianism (Cambridge, 2010).

Müller, Patrick, Latitudinarianism and Didacticism in Eighteenth-Century Literature: Moral Theology in Fielding, Sterne, and Goldsmith (Frankfurt am Main, 2009).

Olsen, V. Norskov, John Foxe and the Elizabethan Church (London, 1973).

Palmer, Thomas, Jansenism and England: Moral Rigorism across the Confessions (Oxford, 2018).

Parkin, Jon, 'Taming the Leviathan: Reading Hobbes in Seventeenth-Century Europe', in Early Modern Natural Law Theories: Contexts and Strategies in the Early Enlightenment, eds., T. J. Hochstrasser and Peter Schröder (Dordrecht, 2003), 31-52. 
- Taming the Leviathan: The Reception of the Political and Religious Ideas of Thomas Hobbes in England, 1640-1700 (Cambridge, 2007).

Passmore, John Arthur, The Perfectibility of Man (London, 1970).

Pocock, J. G. A., The Machiavellian Moment: Florentine Political Thought and the Atlantic Republican Tradition (Princeton, 1975).

Reeves, Marjorie E., The Influence of Prophecy in the Later Middle Ages: A Study in Joachimism (Oxford, 1969).

Rivers, Isabel, Reason, Grace, and Sentiment: A Study of the Language of Religion and Ethics in England, 1660-1780, Vol. 1, Whichcote to Wesley (Cambridge, 1991).

Rose, Craig, 'Providence, Protestant Union and Godly Reformation in the 1690s', Transactions of the Royal Historical Society 3 (1993): 151-69.

Rose, Jacqueline, 'By Law Established: The Church of England and the Royal Supremacy', in The Later Stuart Church, 1660-1714, ed., Grant Tapsell (Manchester, 2012), 21-45.

—, Godly Kingship in Restoration England: The Politics of the Royal Supremacy, 1660-1688 (Cambridge, 2011).

—, 'The Godly Magistrate', in The Oxford History of Anglicanism, Vol. 1, Reformation and Identity, c.1520-1662, ed., Anthony Milton (Oxford, 2017), 103-21.

— , 'Kingship and Councel in Early Modern England', The Historical Journal 54, no. 1 (2011): 47-71.

—, 'Royal Ecclesiastical Supremacy and the Restoration Church', Historical Research 80, no. 209 (2007): 324-45.

Savonius-Wroth, Sami-Juhani, Paul Schuurman, and Jonathan Walmsley, eds., The Continuum Companion to Locke (London, 2010).

Schmidt, Jeremy, Melancholy and the Care of the Soul: Religion, Moral Philosophy and Madness in Early Modern England (Aldershot, 2007).

Shapiro, B. J., 'Latitudinarianism and Science in Seventeenth-Century England', Past and Present 40, no. 1 (1968): 16-41.

Shell, Alison, Catholicism, Controversy, and the English Literary Imagination, 15581660 (Cambridge, 1999). 
Sirota, Brent S., The Christian Monitors: The Church of England and the Age of Benevolence, 1680-1730 (New Haven, 2014).

Skinner, Quentin, The Foundations of Modern Political Thought, Vol. 1, the Renaissance (Cambridge, 1978).

Spellman, W. M., The Latitudinarians and the Church of England, 1660-1700 (Athens, Georgia, 1993).

Spurr, John, 'The Church of England, Comprehension and the Toleration Act of 1689', English Historical Review 104, no. 413 (1989): 927-46.

—, "Latitudinarianism" and the Restoration Church', The Historical Journal 31, no. 1 (1988): 61-82.

—, The Post-Reformation: Religion, Politics and Society in Britain, 1603-1714 (Harlow, 2006).

—, "Rational Religion" in Restoration England', Journal of the History of Ideas 49, no. 4 (1988): 563-85.

— The Restoration Church of England, 1646-1689 (New Haven, 1991).

- 'Schism and the Restoration Church', Journal of Ecclesiastical History 41, no. 3 (1990): 408-24.

— 'Shaftesbury and the Politics of Religion', in Anthony Ashley Cooper, First Earl of Shaftesbury, 1621-1683, ed., John Spurr (Farnham, 2011), 127-51.

—, “A Special Kindness for Dead Bishops": The Church, History, and Testimony in Seventeenth-Century Protestantism', in The Uses of History in Early Modern England, ed., Paulina Kewes (San Marino, California, 2006), 307-28.

_ , "Virtue, Religion and Government": The Anglican Uses of Providence', in The Politics of Religion in Restoration England, eds., Tim Harris, Paul Seaward and Mark Goldie (Oxford, 1990), 29-47.

Starkie, Andrew, The Church of England and the Bangorian Controversy: 1716-1721 (Woodbridge, 2007).

—, 'Contested Histories of the English Church: Gilbert Burnet and Jeremy Collier', in The Uses of History in Early Modern England, ed., Paulina Kewes (San Marino, California, 2006), 329-45. 
— - 'Gilbert Burnet's Reformation and the Semantics of Popery', in Fear, Exclusion and Revolution: Roger Morrice and Britain in the 1680s, ed., Jason McElligott (Aldershot, 2006), 138-53.

Stewart, M. A., English Philosophy in the Age of Locke (Oxford, 2000).

Sykes, Stephen, and John E. Booty, eds., The Study of Anglicanism (London, 1988).

Taithe, Bertrand, and Tim Thornton, eds., Prophecy: The Power of Inspired Language in History 1300-2000 (Stroud, 1997).

Taylor, Stephen, 'Afterword: State Formation, Political Stability and the Revolution of 1688', in The Final Crisis of the Stuart Monarchy: The Revolutions of 1688-91 in Their British, Atlantic and European Contexts, eds., Tim Harris and Stephen Taylor (Woodbridge, 2013), 273-304.

Thomas, Keith, Religion and the Decline of Magic: Studies in Popular Beliefs in Sixteenth and Seventeenth Century England (London, 1971edition).

Toon, Peter, Puritans, the Millennium and the Future of Israel: Puritan Eschatology, 1600 to 1660 (Cambridge, 1970).

Tuveson, Ernest Lee, Millennium and Utopia: A Study in the Background of the Idea of Progress (New York, 1964).

Tyacke, Nicholas, 'From Laudians to Latitudinarians: A Shifting Balance of Theological Force', in The Later Stuart Church, 1660-1714, ed., Grant Tapsell (Manchester, 2012), 46-67.

Van Leeuwen, Henry G., The Problem of Certainty in English Thought, 1630-1690 (The Hague, 1963).

VanderMolen, Ronald J., 'Providence as Mystery, Providence as Revelation: Puritan and Anglican Modifications of John Calvin's Doctrine of Providence', Church History 47, no. 1 (1978): 27-47.

Wainwright, Arthur William, Mysterious Apocalypse: Interpreting the Book of Revelation (Nashville, 1993).

Walsham, Alexandra, 'History, Memory, and the English Reformation', The Historical Journal 55, no. 4 (2012): 899-938.

—, Providence in Early Modern England (Oxford, 1999).

Wickins, Peter, Victorian Protestantism and Bloody Mary: The Legacy of Religious Persecution in Tudor England (Bury St. Edmunds, 2012). 
Willey, Basil, The Seventeenth Century Background: Studies in the Thought of the Age in Relation to Poetry and Religion (London, 1934).

Wilson, Kathleen, 'A Dissident Legacy: Eighteenth Century Popular Politics and the Glorious Revolution', in Liberty Secured?: Britain before and after 1688, ed., James Rees Jones (Stanford, 1992), 299-334.

Winship, Michael P., Godly Republicanism Puritans, Pilgrims, and a City on a Hill (Cambridge, Mass., 2012).

Zakai, Avihu, Exile and Kingdom: History and Apocalypse in the Puritan Migration to America (Cambridge, 1992).

- Jonathan Edwards' Philosophy of History the Re-Enchantment of the World in the Age of Enlightenment (Princeton, 2003).

—, 'Reformation, History, and Eschatology in English Protestantism', History and Theory 26, no. 3 (1987): 300-18.

— , 'Thomas Brightman and English Apocalyptic Tradition', in Menasseh Ben Israel and His World, eds., Yosef Kaplan, Henry Méchoulan and Richard H. Popkin (Leiden, 1989), 31-44.

\section{Unpublished Theses}

Bulman, William J., 'Constantine's Enlightenment: Culture and Religious Politics in the Early British Empire, C. 1648-1710', Ph.D dissertation, Princeton University, 2009.

Drinnon, David Andrew, 'The Apocalyptic Tradition in Scotland, 1588-1688', Ph.D. dissertation, University of St Andrews, 2013.

Kroeze, George, 'The Variety of Millennial Hopes in the English Reformation', Ph.D. dissertation, Fuller Theological Seminary, 1985. 